\title{
Catalytic Ring Expansions of Cyclic Alcohols Enabled by Proton-Coupled Electron Transfer
}

Kuo Zhao $^{\dagger \ddagger}$, Kenji Yamashita ${ }^{\dagger \ddagger}$, Joseph E. Carpenter ${ }^{\S}$, Trevor C. Sherwood ${ }^{\S}$, William R. Ewing ${ }^{\S}$, Peter T. W. Cheng ${ }^{\S}$, and Robert R. Knowles ${ }^{\dagger *}$

'Department of Chemistry, Princeton University, Princeton, New Jersey 08544, United States

${ }^{\S}$ Discovery Chemistry, Bristol-Myers Squibb Co., Princeton, New Jersey 08543, United States

Correspondence to: rknowles@princeton.edu

Supporting Information

Table of Contents $\quad$ Page

$\begin{array}{ll}\text { General Information } & \text { S2 }\end{array}$

Synthesis of Starting Materials for $n+2$ Chemistry $\quad$ S3

$\begin{array}{ll}\text { Synthesis of Starting Materials for } n+1 \text { Chemistry } & \text { S15 }\end{array}$

$\begin{array}{ll}\text { Synthesis of Products } & \text { S29 }\end{array}$

$\begin{array}{ll}\text { Proposed Catalytic Cycle for } n+2 \text { Ring Expansion } & \text { S30 }\end{array}$

Proposed Catalytic Cycles for $n+1$ Ring Expansion $\quad$ S32

${ }^{1} \mathrm{H}$ and ${ }^{13} \mathrm{C}$ NMR Spectra of Products $\quad$ S51

References $\quad$ S86 


\section{General Information}

Commercial reagents were purified prior to use following the guidelines of Perrin and Armarego. ${ }^{1}$ All solvents were purified according to the method of Grubbs. ${ }^{2}$ Organic solutions were concentrated under reduced pressure on a Büchi rotary evaporator using a water bath. Chromatographic purification of products was accomplished by flash chromatography on a Biotage Isolera One with cartridges containing Fluka 230-400 mesh silica gel. Thin-layer chromatography (TLC) was performed on Silicycle $250 \mu \mathrm{m}$ silica gel plates. Visualization of the developed chromatogram was performed by irradiation with UV light or treatment with a solution of phosphomolybdic acid, ceric ammonium molybdate, $p$-anisaldehyde stains, and cobalt (II) thiocyanate followed by heating when necessary. ${ }^{3}$ Yields refer to purified compounds unless otherwise noted.

All ${ }^{1} \mathrm{H}$, NOESY, and ${ }^{13} \mathrm{C}\left\{{ }^{1} \mathrm{H}\right\}$ NMR spectra were recorded on Bruker Avance II 500 (500 and $126 \mathrm{MHz}$ for ${ }^{1} \mathrm{H}$ and ${ }^{13} \mathrm{C}$ respectively), Bruker Avance III HD $400\left(400\right.$ and $101 \mathrm{MHz}$ for ${ }^{1} \mathrm{H}$ and ${ }^{13} \mathrm{C}$ respectively) instruments, and were referenced to residual protio-solvent signals: $\mathrm{CDCl}_{3}$ at $\delta 7.26$ and $77.16 \mathrm{ppm}$, and DMSO- $d_{6}$ at $\delta 2.50$ and $39.52 \mathrm{ppm}$. Data for ${ }^{1} \mathrm{H}$ NMR are reported as follows: chemical shift $(\delta$ ppm), broad peak (b), multiplicity $(\mathrm{s}=$ singlet, $\mathrm{d}=$ doublet, $\mathrm{t}=$ triplet, $q=$ quartet, $\mathrm{p}=$ pentet, $\mathrm{h}=$ hextet, $\mathrm{m}=$ multiplet $)$, coupling constant $(\mathrm{Hz})$ and integration; data for ${ }^{13} \mathrm{C}$ NMR are reported in terms of chemical shift and no special nomenclature is used for equivalent carbons. In certain starting materials and products, the presence of the $N$-Boc group result in rotameric products, and for selected compounds, the NMR characterization issues were addressed by acquiring NMR spectral in DMSO- $d_{6}$ at $120{ }^{\circ} \mathrm{C}$, otherwise, the characterizations of rotameric products were included. IR spectra were recorded on a Thermo Scientific Nicolet 6700 FT-IR spectrometer and are reported in terms of frequency of absorption $\left(\mathrm{cm}^{-1}\right)$. High-resolution mass spectra were obtained at Princeton University Mass Spectrometry Facility using an Agilent 6210 TOF LC/MS (Electrospray Ionization, ESI) or an Agilent 7200 Q-TOF GC/MS (Electron Ionization, EI) or at Princeton University Proteomics and Mass Spectrometry Core Facility using a Thermo Scientific LTQ Orbitrap XL Mass Spectrometer (Electrospray Ionization, ESI).

Bases were made in similar fashion as previous work. ${ }^{4}$ In the case of tetrabutylphosphonium 2,2,2-trifluoroacetate base (TFA base), $\mathrm{CF}_{3} \mathrm{COOH}$ was used as the acid of the reaction. 


\section{Synthesis of Starting Materials for $n+2$ Chemistry}

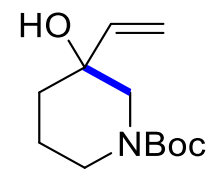

tert-butyl 3-hydroxy-3-vinylpiperidine-1-carboxylate (1)

The titled compound was synthesized by vinylation of tert-butyl 3-oxopiperidine-1-carboxylate. ${ }^{5}$

To an oven-dried 50-mL round-bottomed flask, charged with a stir bar, was added vinylmagnesium chloride (15.1 mmol, 3.00 eq., 9.5 mL, 1.6 M THF solution) under inert atmosphere. The solution was cooled to $0{ }^{\circ} \mathrm{C}$, and a THF solution of tert-butyl 3-oxopiperidine-1-carboxylate $(5.02 \mathrm{mmol}$, 1.00 eq., $1.00 \mathrm{~g}, 10 \mathrm{~mL}$ THF) was added in dropwise. The mixture was allowed to warm to r.t. and stirred for $14 \mathrm{~h}$. Afterwards, the reaction was quenched with sat. aq. $\mathrm{NH}_{4} \mathrm{Cl}(30 \mathrm{~mL})$, extracted in $\mathrm{Et}_{2} \mathrm{O}(20 \mathrm{~mL}$, three times). The combined organic layers were washed with sat. aq. $\mathrm{NaCl}(40 \mathrm{~mL})$, dried over anhydrous $\mathrm{MgSO}_{4}$, filtered, and concentrated to a small volume. This crude was purified by silica gel flash column chromatography (5\% to $28 \%$ EtOAc in hexanes) to obtain the titled compound (900.0 mg, 79\% yield) as a colorless oil which slowly solidified to a white solid. ${ }^{1} \mathbf{H}$ NMR (500 MHz, CDCl 3 , mixture of rotamers) $\delta 5.91(\mathrm{dd}, J=17.3,10.9 \mathrm{~Hz}, 1 \mathrm{H}), 5.38(\mathrm{dd}, J=$ $17.4,1.2 \mathrm{~Hz}, 1 \mathrm{H}), 5.16(\mathrm{dd}, J=10.8,1.2 \mathrm{~Hz}, 1 \mathrm{H}), 3.81(\mathrm{dt}, J=13.2,4.5 \mathrm{~Hz}, 1 \mathrm{H}), 3.66(\mathrm{br}, 1 \mathrm{H})$, $3.14-2.89$ (m, 2H), $1.96-1.74(\mathrm{~m}, 2 \mathrm{H}), 1.74-1.55$ (m, 2H), 1.46 (s, 9H). ${ }^{13}$ C NMR (126 MHz, $\mathrm{CDCl}_{3}$, mixture of rotamers) $\delta 155.86,142.30,114.10,79.98,70.66,53.27,44.67,35.78,28.54$, 21.36. IR (neat): 3434, 2967, 2936, 2662, 1668, 1431, 1464, 1267, 1165, 901, 701, $591 \mathrm{~cm}^{-1}$. HRMS (ESI): exact mass calculated for $[\mathrm{M}+\mathrm{Na}]^{+}\left(\mathrm{C}_{12} \mathrm{H}_{21} \mathrm{NNaO}_{3}\right)$ requires $m / z 250.14136$, found $m / z 250.14103$.

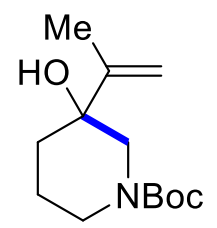

tert-butyl 3-hydroxy-3-(prop-1-en-2-yl)piperidine-1-carboxylate (2)

The titled compound was synthesized by isopropenylation of tert-butyl 3-oxopiperidine-1carboxylate. ${ }^{5}$

To an oven-dried 50-mL round-bottomed flask, charged with a stir bar, was added prop-1-en-2ylmagnesium bromide (7.53 mmol, 3.00 eq., $15.0 \mathrm{~mL}, 0.5 \mathrm{M}$ THF solution) under inert atmosphere. The solution was cooled to $0{ }^{\circ} \mathrm{C}$, and a THF solution of tert-butyl 3-oxopiperidine1-carboxylate $(2.51 \mathrm{mmol}, 1.00$ eq., $0.500 \mathrm{~g}, 10 \mathrm{~mL}$ THF) was added in dropwise. The mixture was allowed to warm to r.t. and stirred for $18 \mathrm{~h}$. Afterwards, the reaction was quenched with sat. aq. $\mathrm{NH}_{4} \mathrm{Cl}(15 \mathrm{~mL})$, extracted in $\mathrm{Et}_{2} \mathrm{O}(15 \mathrm{~mL}$, three times $)$. The combined organic layers were washed with sat. aq. $\mathrm{NaCl}(20 \mathrm{~mL})$, dried over anhydrous $\mathrm{MgSO}_{4}$, filtered, and concentrated to a small volume. This crude was purified by silica gel flash column chromatography ( $5 \%$ to $28 \%$ EtOAc in hexanes) to obtain the titled compound $(212 \mathrm{mg}, 35 \%$ yield) as a colorless oil which slowly solidified to a white solid. ${ }^{1} \mathbf{H}$ NMR (500 $\mathbf{M H z}, \mathbf{C D C l}_{3}$, mixture of rotamers) $\delta 5.05$ (s, $1 \mathrm{H}), 4.90(\mathrm{~s}, 1 \mathrm{H}), 4.08-3.53(\mathrm{~m}, 2 \mathrm{H}), 3.22-2.88(\mathrm{~m}, 1 \mathrm{H}), 2.80(\mathrm{ddd}, J=13.2,11.7,3.2 \mathrm{~Hz}, 1 \mathrm{H})$, $2.06-1.78(\mathrm{~m}, 4 \mathrm{H}), 1.78-1.63(\mathrm{~m}, 2 \mathrm{H}), 1.54-1.48(\mathrm{~m}, 1 \mathrm{H}), 1.46(\mathrm{~s}, 9 \mathrm{H}) .{ }^{13} \mathbf{C}$ NMR (126 MHz, 
$\mathbf{C D C l}_{3}$, mixture of rotamers) $\delta 155.30,141.75,111.16,80.03,72.47,52.73,49.55,34.14,28.57$, 21.33, 19.04. IR (neat): 3434, 2964, 2940, 2868, 1665, 1439, 1310, 1274, 1151, 882, 768, 590 $\mathrm{cm}^{-1}$. HRMS (ESI): exact mass calculated for $[\mathrm{M}+\mathrm{Na}]^{+}\left(\mathrm{C}_{13} \mathrm{H}_{23} \mathrm{NNaO}_{3}\right)$ requires $\mathrm{m} / z$ 264.15701, found $\mathrm{m} / \mathrm{z} 264.15697$.

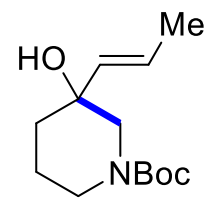

tert-butyl (E)-3-hydroxy-3-(prop-1-en-1-yl)piperidine-1-carboxylate (3)

The titled compound was synthesized by Red-Al ${ }^{\circledR}$ reduction of tert-butyl 3-hydroxy-3-(prop-1-yn1-yl)piperidine-1-carboxylate, which was synthesized by propynylation of tert-butyl 3oxopiperidine-1-carboxylate.,
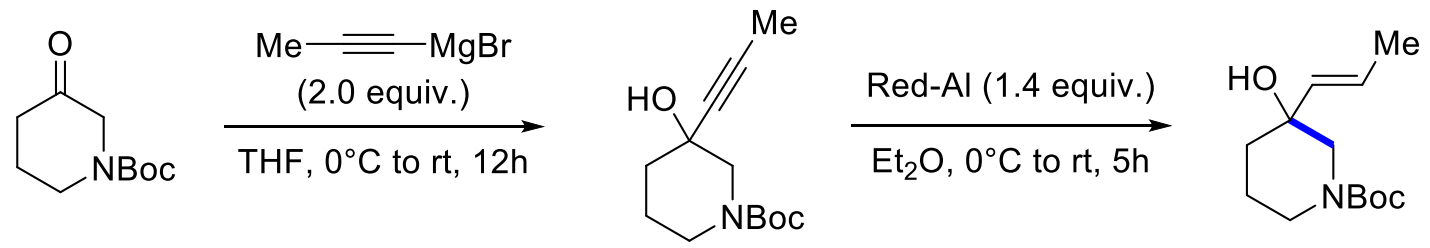

To an oven-dried 100-mL round-bottomed flask, charged with a stir bar, was added prop-1-yn-1ylmagnesium bromide (20.08 mmol, 2.0 eq., $40 \mathrm{~mL}, 0.5 \mathrm{M}$ THF solution) under inert atmosphere. The solution was cooled to $0{ }^{\circ} \mathrm{C}$, and a THF solution of tert-butyl 3-oxopiperidine-1-carboxylate (10.0 mmol, 1.00 eq., $2.00 \mathrm{~g}, 20 \mathrm{~mL}$ THF) was added dropwise. The mixture was allowed to warm to r.t. and stirred for $12 \mathrm{~h}$. Afterwards, the reaction was quenched with sat. aq. $\mathrm{NH}_{4} \mathrm{Cl}(40 \mathrm{~mL})$, extracted in $\mathrm{Et}_{2} \mathrm{O}(30 \mathrm{~mL}$, three times). The combined organic layers were washed with sat. aq. $\mathrm{NaCl}(40 \mathrm{~mL})$, dried over anhydrous $\mathrm{MgSO}_{4}$, filtered, and concentrated to a small volume. This crude was purified by silica gel flash column chromatography (10\% to $40 \%$ EtOAc in hexanes) to obtain the tert-butyl 3-hydroxy-3-(prop-1-yn-1-yl)piperidine-1-carboxylate (1.85 g, 77\% yield) as a pale yellow oil.

Data for tert-butyl 3-hydroxy-3-(prop-1-yn-1-yl)piperidine-1-carboxylate:

${ }^{1} \mathrm{H}$ NMR (500 MHz, $\mathbf{C D C l}_{3}$, mixture of rotamers) $\delta 3.75-2.99(\mathrm{~m}, 4 \mathrm{H}), 2.56-1.92(\mathrm{~m}, 1 \mathrm{H})$, $1.89-1.55(\mathrm{~m}, 6 \mathrm{H}), 1.45(\mathrm{~s}, 9 \mathrm{H}) .{ }^{\mathbf{1}} \mathbf{C} \mathbf{~ N M R}\left(\mathbf{1 2 6} \mathbf{~ M H z}, \mathbf{C D C l}_{\mathbf{3}}\right.$, mixture of rotamers) $\delta 155.09$, 81.06, 79.84, 66.20, 66.01, 55.03, 44.53, 43.25, 38.28, 28.56, 21.92, 15.42. IR (neat): 3401, 2922, 2867, 1684, 1425, 1384, 1243, 1161, 1068, $870 \mathrm{~cm}^{-1}$. HRMS (ESI): exact mass calculated for $[\mathrm{M}+\mathrm{Na}]^{+}\left(\mathrm{C}_{13} \mathrm{H}_{21} \mathrm{NNaO}_{3}\right)$ requires $m / z$ 262.14136, found $m / z 262.14160$.

To an oven-dried 50-mL round-bottomed flask, charged with a stir bar, was added tert-butyl 3hydroxy-3-(prop-1-yn-1-yl)piperidine-1-carboxylate (2.44 mmol, 1.00 eq., $584.0 \mathrm{mg})$. Under inert atmosphere, $\mathrm{Et}_{2} \mathrm{O}(20 \mathrm{~mL})$ was added, and the solution was cooled to $0{ }^{\circ} \mathrm{C}$. At the same temperature, sodium bis(2-methoxyethoxy)aluminum hydride (3.42 mmol, 1.40 eq., $1.1 \mathrm{~mL}, 60 \%$ $\mathrm{w} / \mathrm{w}$ toluene solution) was added slowly and dropwise. During the addition of reagent, hydrogen gas evolution was observed, and the solution slowly turned cloudy. The suspension was then allowed to warm up to r.t and stir for another $5 \mathrm{~h}$. The mixture was then cooled to $0{ }^{\circ} \mathrm{C}$ and was 
quenched by dropwise addition of sat. aq. $\mathrm{NH}_{4} \mathrm{Cl}(5 \mathrm{~mL})$. To the resulting mixture was added sat. aq. $\mathrm{NH}_{4} \mathrm{Cl}(15 \mathrm{~mL})$, aq. $\mathrm{HCl}(2 \mathrm{M}, 10 \mathrm{~mL})$ and $\mathrm{Et}_{2} \mathrm{O}(20 \mathrm{~mL})$. The aqueous layer was separated and then rinsed by $\mathrm{Et}_{2} \mathrm{O}(20 \mathrm{~mL}$, three times $)$. The organic layers were combined, dried over anhydrous $\mathrm{MgSO}_{4}$, filtered and evaporated to afford a colorless oil, which was purified by silica gel flash column chromatography (10\% to $30 \%$ EtOAc in hexanes) to obtain tert-butyl $(E)-3$ hydroxy-3-(prop-1-en-1-yl)piperidine-1-carboxylate (469.0 mg, 80\% yield) as a colorless oil. ${ }^{1} \mathbf{H}$ NMR (500 MHz, CDCl ${ }_{3}$, mixture of rotamers) $\delta 5.79(\mathrm{dq}, J=15.5,6.5 \mathrm{~Hz}, 1 \mathrm{H}), 5.52(\mathrm{dq}, J=$ 15.6, $1.7 \mathrm{~Hz}, 1 \mathrm{H}), 3.87-3.40(\mathrm{~m}, 2 \mathrm{H}), 3.23-2.76(\mathrm{~m}, 2 \mathrm{H}), 2.09-1.64(\mathrm{~m}, 6 \mathrm{H}), 1.64-1.48(\mathrm{~m}$, $1 \mathrm{H}), 1.45(\mathrm{~s}, 9 \mathrm{H}) .{ }^{13} \mathbf{C}$ NMR (126 $\mathbf{~ M H z}, \mathbf{C D C l}_{3}$, mixture of rotamers) $\delta$ 155.10, 135.29, $125.43+125.29,79.88,70.10,53.98,44.13$ 36.16, 28.56, 21.53, 18.07. IR (neat): 3426, 2932, 2868, 1666, 1369, 1364, 1242, 1151, 1062, 967, 766, $463 \mathrm{~cm}^{-1}$. HRMS (ESI): exact mass calculated for $[\mathrm{M}+\mathrm{Na}]^{+}\left(\mathrm{C}_{13} \mathrm{H}_{23} \mathrm{NNaO}_{3}\right)$ requires $m / z$ 264.15701, found $m / z$ 264.15659.

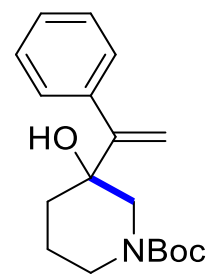

tert-butyl 3-hydroxy-3-(1-phenylvinyl)piperidine-1-carboxylate (4)

The titled compound was synthesized by the ketone insertion of (1-phenylvinyl)magnesium bromide to tert-butyl 3-oxopiperidine-1-carboxylate. ${ }^{7}$

To an oven-dried 50-mL round-bottomed flask, charged with a stir bar, was added magnesium turnings (16.2 mmol, 2.30 eq., $393 \mathrm{mg}$ ) and a chip of iodine under inert atmosphere. THF (1 mL) was then added, and the brown mixture was vigorously stirred for $15 \mathrm{~min}$. Two drops of neat (1bromovinyl)benzene was then added to the mixture to initiate the reaction. The brown color of iodine faded, and the temperature increased significantly in about $2 \mathrm{~min}$. At this point, a THF solution of (1-bromovinyl)benzene (15.5 mmol, 2.20 eq., $2 \mathrm{~mL}, 10 \mathrm{~mL}$ THF) was slowly added to the stirring mixture, and the resulting reaction mixture was stirred at r.t. for $2 \mathrm{~h}$ to afford a gray, cloudy mixture. The solution was cooled to $0{ }^{\circ} \mathrm{C}$, and a THF solution of tert-butyl 3-oxopiperidine1-carboxylate (7.03 mmol, 1.00 eq., $1.40 \mathrm{~g}, 10 \mathrm{~mL}$ THF) was added in dropwise. The mixture was allowed to warm to r.t. and stirred for $12 \mathrm{~h}$. Afterwards, the reaction was quenched with sat. aq. $\mathrm{NH}_{4} \mathrm{Cl}(50 \mathrm{~mL})$, extracted in $\mathrm{Et}_{2} \mathrm{O}(30 \mathrm{~mL}$, three times). The combined organic layers were washed with sat. aq. $\mathrm{NaCl}(30 \mathrm{~mL})$, dried over anhydrous $\mathrm{MgSO}_{4}$, filtered, and concentrated to a small volume. This crude was purified by silica gel flash column chromatography (5\% to 35\% EtOAc in hexanes) to obtain the titled compound (393 $\mathrm{mg}, 18 \%$ yield) as a colorless oil which slowly solidified to a white solid. ${ }^{1} \mathbf{H}$ NMR (500 $\mathbf{~ M H z , ~} \mathbf{C D C l}_{\mathbf{3}}$, mixture of rotamers) $\delta 7.39-7.28(\mathrm{~m}$, $5 \mathrm{H}), 5.51$ (br, 1H), 5.12 (br, 1H), $4.16-3.63(\mathrm{~m}, 2 \mathrm{H}), 3.08(\mathrm{br}, 1 \mathrm{H}), 2.88-2.68(\mathrm{~m}, 1 \mathrm{H}), 2.21-$ $1.65(\mathrm{~m}, 4 \mathrm{H}), 1.45(\mathrm{~s}, 9 \mathrm{H}) .{ }^{13} \mathbf{C}$ NMR (126 MHz, $\mathbf{C D C l}_{3}$, mixture of rotamers) $\delta 157.78,156.58$, $155.26,140.50,114.28,113.79,81.18,80.64,57.93,57.01,56.57,49.54,49.25,28.50$. IR (neat): 3420, 3052, 3004, 2974, 2927, 2867, 1666, 1425, 1390, 1317, 1240, 1147, 1003, 893, 770, 617 $\mathrm{cm}^{-1}$. HRMS (ESI): exact mass calculated for $[\mathrm{M}+\mathrm{Na}]^{+}\left(\mathrm{C}_{18} \mathrm{H}_{25} \mathrm{NNaO}_{3}\right)$ requires $\mathrm{m} / \mathrm{z} 326.17266$, found $m / z 326.17217$. 


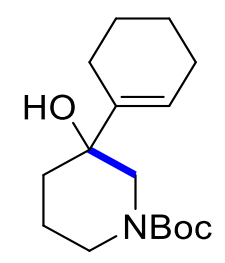

tert-butyl 3-(cyclohex-1-en-1-yl)-3-hydroxypiperidine-1-carboxylate (5)

The titled compound was synthesized by insertion of cyclohex-1-en-1-ylmagnesium bromide to tert-butyl 3-oxopiperidine-1-carboxylate. ${ }^{7}$

To an oven-dried 25-mL three-necked round-bottomed flask, charged with a stir bar and fitted with a condensor, was added magnesium turnings (6.60 mmol, 1.60 eq., $161 \mathrm{mg})$ and a chip of iodine under inert atmosphere. THF ( $4 \mathrm{~mL})$ was then added, and the brown mixture was vigorously stirred for $15 \mathrm{~min}$. Then, two drops of neat 1-bromocyclohex-1-ene was then added to the mixture to initialize the reaction. With gentle heating applied for $15 \mathrm{~min}$ by a heat gun, the brown color faded, the rest of neat 1-bromocyclohex-1-ene (6.21 mmol, 1.5 eq., $1.00 \mathrm{~g})$ was slowly added. Upon completion, the reaction mixture was further stirred for $1.5 \mathrm{~h}$ at r.t. to obtain a gray, cloudy mixture, which was then cooled to $0{ }^{\circ} \mathrm{C}$, and a THF solution of tert-butyl 3-oxopiperidine-1-carboxylate (4.14 mmol, 1.00 eq., $825 \mathrm{mg}, 5 \mathrm{~mL}$ THF) was added dropwise. The mixture was allowed to warm to r.t. and stirred for another $12 \mathrm{~h}$. The reaction was then quenched with sat. aq. $\mathrm{NH}_{4} \mathrm{Cl}(25 \mathrm{~mL})$, extracted in $\mathrm{Et}_{2} \mathrm{O}$ ( $25 \mathrm{~mL}$, three times). The combined organic layers were washed with sat. aq. $\mathrm{NaCl}(25 \mathrm{~mL})$, dried over anhydrous $\mathrm{MgSO}_{4}$, filtered, and concentrated to a small volume. This crude was purified by silica gel flash column chromatography (5\% to $35 \%$ EtOAc in hexanes) to obtain the titled compound $(218 \mathrm{mg}, 19 \%$ yield) as a colorless oil which slowly solidified to a white solid. ${ }^{1} \mathbf{H}$ NMR (500 $\mathbf{~ M H z , ~} \mathbf{C D C l}_{3}$, mixture of rotamers) $\delta 5.89-5.73(\mathrm{~m}, 1 \mathrm{H}), 3.98-$ $3.56(\mathrm{~m}, 2 \mathrm{H}), 3.02(\mathrm{br}, 1 \mathrm{H}), 2.82(\mathrm{ddd}, J=13.2,11.4,3.3 \mathrm{~Hz}, 1 \mathrm{H}), 2.14-1.96(\mathrm{~m}, 4 \mathrm{H}), 1.89-$ $1.48(\mathrm{~m}, 8 \mathrm{H}), 1.46(\mathrm{~s}, 9 \mathrm{H}) .{ }^{13} \mathbf{C}$ NMR $\left(126 \mathbf{~ M H z}, \mathbf{C D C l}_{3}\right.$, mixture of rotamers) $\delta 155.93,140.63$, $121.96,79.89,72.18,60.25,52.93,34.03,28.58,25.33,24.12,23.12,22.37,21.45$. IR (neat): 3425, 2925, 2856, 1680, 1424, 1390, 1296, 1242, 1147, 1006, 901, 765, $548 \mathrm{~cm}^{-1}$. HRMS (ESI): exact mass calculated for $[\mathrm{M}+\mathrm{Na}]^{+}\left(\mathrm{C}_{16} \mathrm{H}_{27} \mathrm{NNaO}_{3}\right)$ requires $m / z$ 304.18831, found $m / z$ 304.18831.

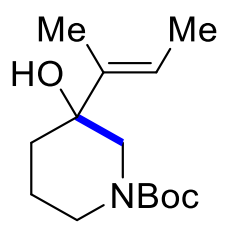

tert-butyl (E)-3-(but-2-en-2-yl)-3-hydroxypiperidine-1-carboxylate (6)

The titled compound was synthesized by insertion of but-2-en-2-ylmagnesium bromide to tertbutyl 3-oxopiperidine-1-carboxylate. ${ }^{7}$

To an oven-dried 50-mL round-bottomed flask, charged with a stir bar, was added magnesium turnings (17.1 mmol, 1.70 eq., $415 \mathrm{mg}$ ) and a chip of iodine under inert atmosphere. THF (4 mL) was then added, and the brown mixture was vigorously stirred for $15 \mathrm{~min}$. Then, two drops of neat $(E)$-2-bromobut-2-ene was then added to the mixture. The brown color faded, and the temperature increased significantly in about $2 \mathrm{~min}$. At this point, a THF solution of $(E)$-2-bromobut-2-ene (15.5 mmol, 1.50 eq., $1.5 \mathrm{~mL}, 10 \mathrm{~mL}$ THF) was slowly added to the stirring mixture, and the resulting reaction mixture was stirred at r.t. for $2 \mathrm{~h}$ to afford a gray, cloudy mixture. The solution was cooled 
to $0{ }^{\circ} \mathrm{C}$, and a THF solution of tert-butyl 3-oxopiperidine-1-carboxylate ( $10.04 \mathrm{mmol}, 1.00$ eq., 2.0 $\mathrm{g}, 10 \mathrm{~mL}$ THF) was added in dropwise. The mixture was allowed to warm to r.t. and stirred for 12 h. Afterwards, the reaction was quenched with sat. aq. $\mathrm{NH}_{4} \mathrm{Cl}(50 \mathrm{~mL})$, extracted in $\mathrm{Et}_{2} \mathrm{O}(30 \mathrm{~mL}$, three times). The combined organic layers were washed with sat. aq. $\mathrm{NaCl}(30 \mathrm{~mL})$, dried over anhydrous $\mathrm{MgSO}_{4}$, filtered, and concentrated to a small volume. This crude was purified by silica gel flash column chromatography (5\% to $35 \%$ EtOAc in hexanes) to obtain the titled compound $(161.0 \mathrm{mg}, 6 \%$ yield) as a colorless oil which slowly solidified to a white solid. Notably, the reaction also furnished small amount of the $Z$ isomer, whose $\mathrm{R}_{\mathrm{f}}$ value is slightly lower than the desired $E$ isomer. ${ }^{1} \mathbf{H}$ NMR (500 $\mathbf{~ M H z}, \mathbf{C D C l}_{3}$, mixture of rotamers) $\delta 5.63(\mathrm{qq}, J=8.5,1.6 \mathrm{~Hz}$, $1 \mathrm{H}), 4.15-3.53(\mathrm{~m}, 2 \mathrm{H}), 3.18-2.89(\mathrm{~m}, 1 \mathrm{H}), 2.80$ (ddd, $J=13.2,11.6,3.2 \mathrm{~Hz}, 1 \mathrm{H}), 1.89-1.76(\mathrm{~m}$, 2H), $1.74-1.66$ (m, 4H), 1.63 (dd, $J=6.5,1.8 \mathrm{~Hz}, 3 \mathrm{H}), 1.59-1.47$ (m, 1H), 1.46 (s, 9H). ${ }^{13}$ C NMR $\left(126 \mathrm{MHz}, \mathrm{CDCl}_{3}\right.$, mixture of rotamers) $\delta 156.1,138.30,124.22,79.94,73.24,52.50$, 44.57+43.86, 34.09, 28.57, 21.49, 13.62, 12.20. IR (neat): 3431, 3008, 2976, 2926, 1669, 1424, $1364,1270,1147,1004,869,766,635 \mathrm{~cm}^{-1}$. HRMS (ESI): exact mass calculated for $[\mathrm{M}+\mathrm{Na}]^{+}$ $\left(\mathrm{C}_{14} \mathrm{H}_{25} \mathrm{NNaO}_{3}\right)$ requires $m / z 278.17266$, found $m / z 278.17263$.

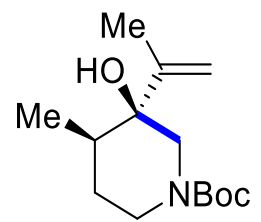

tert-butyl ( $\left.3 S^{*}, 4 R^{*}\right)$-3-hydroxy-4-methyl-3-(prop-1-en-2-yl)piperidine-1-carboxylate (7) The titled compound was synthesized by isopropenylation of tert-butyl 4-methyl-3-oxopiperidine1-carboxylate. ${ }^{5}$

To an oven-dried 50-mL round-bottomed flask, charged with a stir bar, was added prop-1-en-2ylmagnesium bromide (10.0 mmol, 2.04 eq., $20.0 \mathrm{~mL}, 0.5 \mathrm{M}$ THF solution) under inert atmosphere. The solution was cooled to $0{ }^{\circ} \mathrm{C}$, and a THF solution of tert-butyl 4-methyl-3oxopiperidine-1-carboxylate ( $4.69 \mathrm{mmol}, 1.00$ eq., $1.00 \mathrm{~g}, 10 \mathrm{~mL}$ THF) was added in dropwise. The mixture was allowed to warm to r.t. and stirred for $12 \mathrm{~h}$. Afterwards, the reaction was quenched with sat. aq. $\mathrm{NH}_{4} \mathrm{Cl}(40 \mathrm{~mL})$, extracted in $\mathrm{Et}_{2} \mathrm{O}(30 \mathrm{~mL}$, three times). The combined organic layers were washed with sat. aq. $\mathrm{NaCl}(30 \mathrm{~mL})$, dried over anhydrous $\mathrm{MgSO}_{4}$, filtered, and concentrated to a small volume. This crude was purified by silica gel flash column chromatography ( $5 \%$ to $35 \%$ EtOAc in hexanes) to obtain the titled compound ( $457.3 \mathrm{mg}, 38 \%$ yield) as a white solid. Notably, the other diastereomer, which has a slightly lower $\mathrm{R}_{\mathrm{f}}$, was generated in a small quantity and was not recovered. ${ }^{1} \mathbf{H}$ NMR (500 $\mathbf{~ M H z}, \mathbf{C D C l}_{3}$, mixture of rotamers) $\delta 5.14(\mathrm{~s}, 1 \mathrm{H}), 4.97(\mathrm{~s}, 1 \mathrm{H})$, 4.12 (br, $1 \mathrm{H}), 3.84$ (br, $1 \mathrm{H}), 2.87(\mathrm{~d}, J=13.7 \mathrm{~Hz}, 1 \mathrm{H}), 2.71(\mathrm{br}, 1 \mathrm{H}), 1.84-1.72(\mathrm{~m}, 5 \mathrm{H}), 1.65-1.53$ (m, 1H), 1.46 (s, 9H), 0.81-0.79 (m, 3H). ${ }^{13} \mathbf{C}$ NMR (126 MHz, $\mathbf{C D C l}_{3}$, mixture of rotamers) $\delta$ $156.37,147.16,112.03,80.05,75.44,53.87,44.97,35.94,29.14,28.55,19.85,14.82$. IR (neat): 3465, 2972, 2962, 2921, 2851, 1660, 1429, 1364, 1164, 1027, 893, $647 \mathrm{~cm}^{-1}$. HRMS (ESI): exact mass calculated for $[\mathrm{M}+\mathrm{Na}]^{+}\left(\mathrm{C}_{14} \mathrm{H}_{25} \mathrm{NNaO}_{3}\right)$ requires $\mathrm{m} / z$ 278.17266, found $m / z$ 278.17275. 


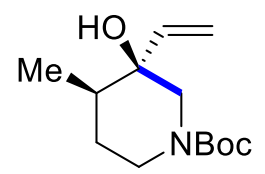

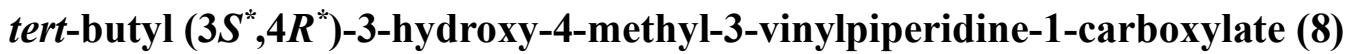

The titled compound was synthesized by vinylation of tert-butyl 4-methyl-3-oxopiperidine-1carboxylate. $^{5}$

To an oven-dried 50-mL round-bottomed flask, charged with a stir bar, was added vinylmagnesium chloride (9.38 mmol, 2.0 eq., $6.2 \mathrm{~mL}, 1.6 \mathrm{M}$ THF solution) under inert atmosphere. The solution was cooled to $0{ }^{\circ} \mathrm{C}$, and a THF solution of tert-butyl 4-methyl-3-oxopiperidine-1-carboxylate (4.69 mmol, 1.00 eq., $1.0 \mathrm{~g}, 10 \mathrm{~mL}$ THF) was added dropwise. The mixture was allowed to warm to r.t. and stirred for $12 \mathrm{~h}$. Afterwards, the reaction was quenched with sat. aq. $\mathrm{NH}_{4} \mathrm{Cl}(40 \mathrm{~mL})$, extracted in $\mathrm{Et}_{2} \mathrm{O}$ (30 mL, three times). The combined organic layers were washed with sat. aq. $\mathrm{NaCl}(30$ $\mathrm{mL}$ ), dried over anhydrous $\mathrm{MgSO}_{4}$, filtered, and concentrated to a small volume. This crude was purified by silica gel flash column chromatography (5\% to 35\% EtOAc in hexanes) to obtain the titled compound (564.3 mg, 50\% yield) as a colorless oil which solidified slowly to a white solid. In addition, the other diastereomer, which has a slightly lower $\mathrm{R}_{\mathrm{f}}$, was also recovered (320 mg, 28\% yield) but was not used in the ring expansion reaction. ${ }^{1} \mathbf{H}$ NMR (500 $\mathbf{~ M H z}, \mathbf{C D C l}_{3}$, mixture of rotamers) $\delta 5.98(\mathrm{dd}, J=17.4,11.0 \mathrm{~Hz}, 1 \mathrm{H}), 5.36(\mathrm{dd}, J=17.4,1.4 \mathrm{~Hz}, 1 \mathrm{H}), 5.24(\mathrm{dd}, J=11.0$, $1.4 \mathrm{~Hz}, 1 \mathrm{H}), 4.15-3.76(\mathrm{~m}, 2 \mathrm{H}), 3.05-2.67(\mathrm{~m}, 2 \mathrm{H}), 1.74-1.53(\mathrm{~m}, 3 \mathrm{H}), 1.44(\mathrm{~s}, 9 \mathrm{H}), 0.89(\mathrm{~d}, J=$ $6.7 \mathrm{~Hz}, 3 \mathrm{H}) .{ }^{13} \mathbf{C ~ N M R ~ ( 1 2 6 ~ M H z , ~} \mathbf{C D C l}_{3}$, mixture of rotamers) $\delta 153.65,137.84,115.03,79.85$, 73.36, 54.78, 52.78, 43.12, 40.72, 30.70, 28.55, 14.72. IR (neat): 3438, 2974, 2932, 2872, 1668, 1428, 1384, 1244, 1169, 898, 764, $640 \mathrm{~cm}^{-1}$. HRMS (ESI): exact mass calculated for [M+Na] ${ }^{+}$ $\left(\mathrm{C}_{13} \mathrm{H}_{23} \mathrm{NNaO}_{3}\right)$ requires $m / z$ 264.15701, found $m / z 264.15673$.

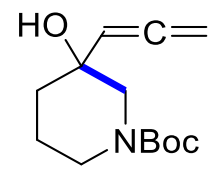

tert-butyl 3-hydroxy-3-(propa-1,2-dien-1-yl)piperidine-1-carboxylate (9)

The titled compound was synthesized by $\mathrm{Cu}(\mathrm{I})$-mediated homologation of tert-butyl 3-ethynyl-3hydroxypiperidine-1-carboxylate, ${ }^{8}$ which was synthesized by ethynylation of tert-butyl 3oxopiperidine-1-carboxylate.

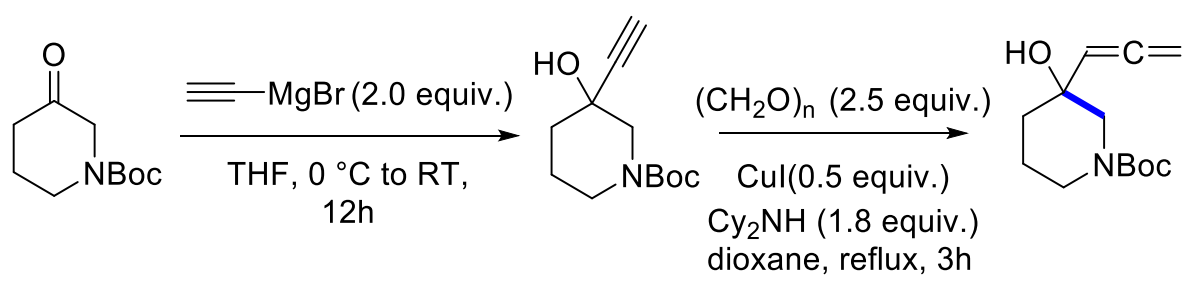

To an oven-dried 50-mL round-bottomed flask, charged with a stir bar, was added ethynylmagnesium bromide (11.2 mmol, 2.00 eq., $22.4 \mathrm{~mL}, 0.5 \mathrm{M}$ THF solution) under inert atmosphere. The solution was cooled to $0{ }^{\circ} \mathrm{C}$, and a THF solution of tert-butyl 3-oxopiperidine1-carboxylate (5.62 mmol, 1.00 eq., $1.12 \mathrm{~g}, 10 \mathrm{~mL}$ THF) was added dropwise. The mixture was allowed to warm to r.t. and stirred for $12 \mathrm{~h}$. Afterwards, the reaction was quenched with sat. aq. 
$\mathrm{NH}_{4} \mathrm{Cl}(20 \mathrm{~mL})$, extracted in $\mathrm{Et}_{2} \mathrm{O}(20 \mathrm{~mL}$, three times). The combined organic layers were washed with sat. aq. $\mathrm{NaCl}(20 \mathrm{~mL})$, dried over anhydrous $\mathrm{MgSO}_{4}$, filtered, and concentrated to a small volume. This crude was purified by silica gel flash column chromatography (10\% to $30 \%$ EtOAc in hexanes) to obtain the tert-butyl 3-ethynyl-3-hydroxypiperidine-1-carboxylate $(1.01 \mathrm{~g}, 80 \%$ yield) as a colorless oil which solidified slowly to a white solid.

Data for tert-butyl 3-ethynyl-3-hydroxypiperidine-1-carboxylate

${ }^{1} \mathrm{H}$ NMR (500 MHz, $\mathbf{C D C l}_{3}$, mixture of rotamers) $\delta 3.91-3.05(\mathrm{~m}, 4 \mathrm{H}), 2.97-2.23(\mathrm{~m}, 2 \mathrm{H})$, 2.05-1.52 (m, 4H), $1.45(\mathrm{~s}, 9 \mathrm{H}) .{ }^{\mathbf{1 3}} \mathbf{C} \mathbf{~ N M R ~ ( 1 2 6 ~} \mathbf{~ M H z}, \mathbf{C D C l}_{\mathbf{3}}$, mixture of rotamers) $\delta 154.92$, 85.58, 80.09, 72.93, 65.97, 54.61, 53.57, 44.58, 43.14, 38.05, 37.37, 28.51, 21.78. IR (neat): 3308, 2975, 2930, 2860, 1954, 1663, 1424, 1365, 1243, 1150, 972, 877, $646 \mathrm{~cm}^{-1}$. HRMS (ESI): exact mass calculated for $[\mathrm{M}+\mathrm{H}]^{+}\left(\mathrm{C}_{12} \mathrm{H}_{20} \mathrm{NO}_{3}\right)$ requires $m / z 226.14377$, found $m / z 226.14372$.

To an oven-dried 25-mL round-bottomed flask, charged with a stir bar and equipped with a condenser, was added paraformaldehyde (10.2 mmol, 2.5 eq., $305 \mathrm{mg})$ and tert-butyl 3-ethynyl-3hydroxypiperidine-1-carboxylate $(4.07 \mathrm{mmol}, 1.0 \mathrm{eq}$., $917 \mathrm{mg})$. Under inert atmosphere, copper (I) iodide ( $2.03 \mathrm{mmol}, 0.5$ eq., $387 \mathrm{mg})$ was added. Then, dicyclohexylamine (7.32 mmol, 1.8 eq., $1.46 \mathrm{~mL})$ and dioxane $(6.8 \mathrm{~mL})$ were added by syringes to afford a brown mixture. The mixture was stirred under reflux for $3 \mathrm{~h}$. The reaction was complete as monitored by TLC and was then allowed to cool to r.t. and filtered to remove solid residue. The collected filtrate was transferred to a separatory funnel and was added water $(20 \mathrm{~mL})$ and $\mathrm{CH}_{2} \mathrm{Cl}_{2}(20 \mathrm{~mL})$. After layer separation, the organic layer was collected, and the aqueous layer was extracted with $\mathrm{CH}_{2} \mathrm{Cl}_{2}(20 \mathrm{~mL}$, three times). Organic layers were combined and was dried over anhydrous $\mathrm{Na}_{2} \mathrm{SO}_{4}$, filtered and evaporated to afford a crude yellow oil, which was purified by silica gel flash column chromatography twice $(10 \%$ to $30 \%$ EtOAc in hexanes) to obtain the tert-butyl 3-hydroxy-3-(propa-1,2-dien-1yl)piperidine-1-carboxylate $\left(911.5 \mathrm{mg}, 94 \%\right.$ yield) as a pale yellow oil. ${ }^{1} \mathbf{H}$ NMR (500 MHz, $\mathbf{C D C l}_{3}$, mixture of rotamers) $\delta 5.32-5.26(\mathrm{~m}, 1 \mathrm{H}), 4.96-4.85(\mathrm{~m}, 2 \mathrm{H}), 4.01-2.80(\mathrm{~m}, 5 \mathrm{H}), 2.27-$ $1.49(\mathrm{~m}, 4 \mathrm{H}), 1.45(\mathrm{~s}, 9 \mathrm{H}) .{ }^{\mathbf{1 3}} \mathbf{C}$ NMR (126 MHz, $\mathbf{C D C l}_{3}$, mixture of rotamers) $\delta 206.57,155.60$, 96.78, 79.92, 78.76, 68.99, 53.61, 44.63, 43.56, 36.24, 28.55, 21.67. IR (neat): 3406, 2974, 2930, 2858, 1954, 1684, 1421, 1364, 1269, 1242, 1160, 836, $764 \mathrm{~cm}^{-1}$. HRMS (ESI): exact mass calculated for $[\mathrm{M}+\mathrm{Na}]^{+}\left(\mathrm{C}_{13} \mathrm{H}_{21} \mathrm{NNaO}_{3}\right)$ requires $m / z$ 262.14136, found $m / z 262.14104$.

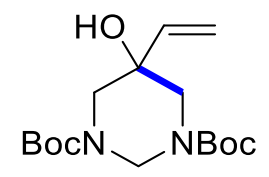

di-tert-butyl 5-hydroxy-5-vinyldihydropyrimidine-1,3(2H,4H)-dicarboxylate (10)

The titled compound was synthesized by vinylation ${ }^{5}$ of di-tert-butyl 5-oxodihydropyrimidine$1,3(2 H, 4 H)$-dicarboxylate, the synthesis of which has been reported previously. ${ }^{9}$

To an oven-dried $25-\mathrm{mL}$ round-bottomed flask, charged with a stir bar, was added vinylmagnesium chloride (5.59 mmol, 2.00 eq., $3.5 \mathrm{~mL}, 1.6 \mathrm{M}$ THF solution) under inert atmosphere. The solution was cooled to $0{ }^{\circ} \mathrm{C}$, and a THF solution of di-tert-butyl 5-oxodihydropyrimidine-1,3(2H,4H)dicarboxylate ( $2.80 \mathrm{mmol}, 1.00$ eq., $840 \mathrm{mg}, 10 \mathrm{~mL}$ THF) was added dropwise. The mixture was allowed to warm to r.t. and stirred for $12 \mathrm{~h}$. Afterwards, the reaction was quenched with sat. aq. $\mathrm{NH}_{4} \mathrm{Cl}(20 \mathrm{~mL})$, extracted in $\mathrm{Et}_{2} \mathrm{O}(20 \mathrm{~mL}$, three times $)$. The combined organic layers were washed 
with sat. aq. $\mathrm{NaCl}(20 \mathrm{~mL})$, dried over anhydrous $\mathrm{MgSO}_{4}$, filtered, and concentrated to a small volume. This crude was purified by silica gel flash column chromatography (10\% to 30\% EtOAc in hexanes) to obtain the titled compound (640 mg, 70\% yield) as a colorless oil, which solidified slowly to a white solid. ${ }^{1} \mathbf{H}$ NMR (500 $\mathbf{~ M H z , ~} \mathbf{C D C l}_{3}$, mixture of rotamers) $\delta 5.84$ (dd, $J=17.4$, $10.9 \mathrm{~Hz}, 1 \mathrm{H}), 5.72$ (br, 1H), 5.50 (d, $J=17.3 \mathrm{~Hz}, 1 \mathrm{H}), 5.26$ (d, $J=10.8 \mathrm{~Hz}, 1 \mathrm{H}), 4.29-3.66$ (m, 3H), $3.08(\mathrm{~d}, J=13.7 \mathrm{~Hz}, 2 \mathrm{H}), 2.13(\mathrm{br}, 1 \mathrm{H}), 1.48(\mathrm{~s}, 18 \mathrm{H}) .{ }^{13} \mathbf{C} \mathbf{N M R}\left(126 \mathbf{M H z}, \mathbf{C D C l}_{3}\right.$, mixture of rotamers) $\delta 154.58,138.70,116.38,80.85,69.69,57.02,52.56,28.42$. IR (neat): 3406, 2974, 2930, 2858, 1954, 1684, 1421, 1391, 1364, 1269, 1242, 1150, 836, $764 \mathrm{~cm}^{-1}$. HRMS (ESI): exact mass calculated for $[\mathrm{M}+\mathrm{Na}]^{+}\left(\mathrm{C}_{16} \mathrm{H}_{28} \mathrm{~N}_{2} \mathrm{NaO}_{5}\right)$ requires $\mathrm{m} / z$ 351.18904, found $\mathrm{m} / z$ 351.18920.

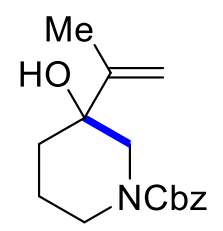

benzyl 3-hydroxy-3-(prop-1-en-2-yl)piperidine-1-carboxylate (11)

The titled compound was synthesized by isopropenylation of benzyl 3-oxopiperidine-1carboxylate. $^{5}$

To an oven-dried 50-mL round-bottomed flask, charged with a stir bar, was added prop-1-en-2ylmagnesium bromide (7.00 mmol, 2.05 eq., $14.0 \mathrm{~mL}, 0.5 \mathrm{M}$ THF solution). The solution was cooled to $0{ }^{\circ} \mathrm{C}$, and a THF solution of benzyl 3-oxopiperidine-1-carboxylate $(3.43 \mathrm{mmol}, 1.00$ eq., $800 \mathrm{mg}, 10 \mathrm{~mL}$ THF) was added in dropwise. The mixture was allowed to warm to r.t. and stirred for $12 \mathrm{~h}$. Afterwards, the reaction was quenched with saturated $\mathrm{NH}_{4} \mathrm{Cl}$ solution $(15 \mathrm{~mL})$, extracted in $\mathrm{Et}_{2} \mathrm{O}$ (15 mL, three times). The combined organic layers were washed with sat. aq. $\mathrm{NaCl}(20$ $\mathrm{mL}$ ), dried over anhydrous $\mathrm{MgSO}_{4}$, filtered, and concentrated to a small volume. This crude was purified by silica gel flash column chromatography (10\% to 30\% EtOAc in hexanes) to obtain the titled compound (291 mg, 31\% yield) as a colorless oil which slowly solidified to a white solid. ${ }^{\mathbf{1}} \mathbf{H}$ NMR (500 MHz, CDCl $\mathbf{~}_{3}$, mixture of rotamers) $\delta 7.39-7.33(\mathrm{~m}, 4 \mathrm{H}), 7.33-7.28(\mathrm{~m}, 1 \mathrm{H}), 5.15(\mathrm{~d}$, $J=2.3 \mathrm{~Hz}, 2 \mathrm{H}), 5.06(\mathrm{~s}, 1 \mathrm{H}), 4.91(\mathrm{t}, J=1.5 \mathrm{~Hz}, 1 \mathrm{H}), 4.24-3.78(\mathrm{~m}, 2 \mathrm{H}), 3.09$ (d, $J=14.0 \mathrm{~Hz}$, 1H), 2.86 (t, $J=12.5 \mathrm{~Hz}, 1 \mathrm{H}), 1.96-1.44(\mathrm{~m}, 7 \mathrm{H}) .{ }^{13} \mathbf{C}$ NMR (126 $\mathbf{M H z}, \mathbf{C D C l}_{3}$, mixture of rotamers) $\delta 155.56,148.54,136.91,128.64,128.13,127.96,111.32,72.25,67.34,52.94,44.51$, 34.06, 21.25, 19.05. IR (neat): 3430, 2948, 2868, 1676, 1497, 1233, 1160, 898, 695, $604 \mathrm{~cm}^{-1}$. HRMS (ESI): exact mass calculated for $[\mathrm{M}+\mathrm{Na}]^{+}\left(\mathrm{C}_{16} \mathrm{H}_{21} \mathrm{NNaO}_{3}\right)$ requires $m / z 298.14136$, found $m / z 298.14114$.

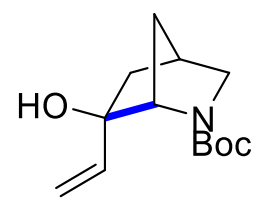

tert-butyl $\left(1 S^{*}, 4 R^{*}, 6 S^{*}\right)$-6-hydroxy-6-vinyl-2-azabicyclo[2.2.1] heptane-2-carboxylate (12)

The titled compound was synthesized by vinylation of tert-butyl $\left(1 S^{*}, 4 R^{*}\right)-6$-oxo-2azabicyclo[2.2.1] heptane-2-carboxylate, ${ }^{5}$ which was prepared by DMP oxidation of commercially available compound tert-butyl $\left(1 S^{*}, 4 R^{*}\right)$-6-hydroxy-2-azabicyclo[2.2.1] heptane-2-carboxylate. ${ }^{9}$ 


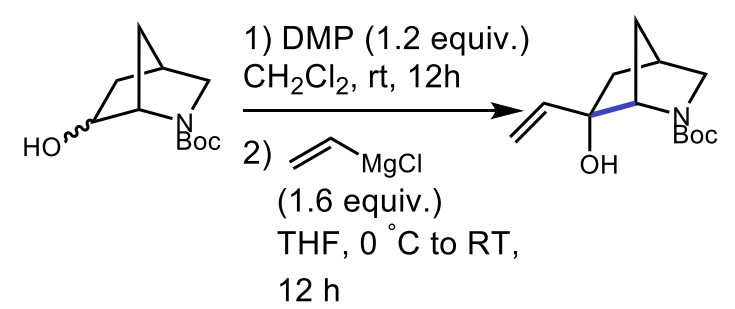

To an oven-dried 50-mL round-bottomed flask, charged with a stir bar, was added a $\mathrm{CH}_{2} \mathrm{Cl}_{2}$ solution of tert-butyl 6-hydroxy-2-azabicyclo[2.2.1] heptane-2-carboxylate (4.69 mmol, 1.00 eq., $1.00 \mathrm{~g}$ in $20 \mathrm{~mL} \mathrm{CH} \mathrm{Cl}_{2}$ ). Then, Dess-Martin periodinane (5.65 mmol, 1.20 eq., $2.40 \mathrm{~g}$ ) was added in one portion. The resulting mixture was stirred at r.t. overnight. The reaction was then quenched by pouring into sat. $\mathrm{NaHCO}_{3}$ aq. $(30 \mathrm{~mL})$, which was saturated by $\mathrm{Na}_{2} \mathrm{~S}_{2} \mathrm{O}_{3}$. After vigorously stirring for $45 \mathrm{~min}$, a bilayer mixture was obtained, and the organic layer was separated, dried over anhydrous $\mathrm{MgSO}_{4}$, filtered, and concentrated to afford the desired ketone product (973.0 mg, 98\%) as a white solid. The spectral data match with literature values. ${ }^{10}$

To an oven-dried 50-mL round-bottomed flask, charged with a stir bar, was added a THF solution of tert-butyl 6-oxo-2-azabicyclo[2.2.1] heptane-2-carboxylate $(4.61 \mathrm{mmol}, 1.00$ eq., $973 \mathrm{mg}, 20$ $\mathrm{mL}$ THF). The solution was cooled to $0{ }^{\circ} \mathrm{C}$, and the solution was dropwise added vinylmagnesium chloride (7.37 mmol, 1.60 eq., $4.6 \mathrm{~mL}, 1.6 \mathrm{M}$ THF solution) under inert atmosphere. The mixture was stirred for $3 \mathrm{~h}$ at $0{ }^{\circ} \mathrm{C}$. Afterwards, the reaction was quenched with sat. aq. $\mathrm{NH}_{4} \mathrm{Cl}(30 \mathrm{~mL})$, extracted in $\mathrm{Et}_{2} \mathrm{O}(20 \mathrm{~mL}$, three times). The combined organic layers were washed with sat. aq. $\mathrm{NaCl}(30 \mathrm{~mL})$, dried over anhydrous $\mathrm{MgSO}_{4}$, filtered, and concentrated to a small volume. This crude was purified by silica gel flash column chromatography (7\% to $50 \%$ EtOAc in hexanes) to obtain the titled compound (744 mg, $68 \%$ yield) as a colorless oil. ${ }^{1} \mathbf{H}$ NMR (500 $\mathbf{~ M H z}, \mathbf{C D C l}_{3}$, mixture of rotamers) $\delta 5.95(\mathrm{dd}, J=17.3,10.7 \mathrm{~Hz}, 1 \mathrm{H}), 5.29(\mathrm{dd}, J=17.3,1.2 \mathrm{~Hz}, 1 \mathrm{H}), 5.16-$ $5.05(\mathrm{~m}, 1 \mathrm{H}), 3.96(\mathrm{~d}, J=45.6 \mathrm{~Hz}, 1 \mathrm{H}), 3.35(\mathrm{~s}, 1 \mathrm{H}), 3.11(\mathrm{dd}, J=9.5,1.3 \mathrm{~Hz}, 1 \mathrm{H}), 2.61-1.82(\mathrm{~m}$, 3H), $1.69-1.60(\mathrm{~m}, 2 \mathrm{H}), 1.47(\mathrm{~s}, 9 \mathrm{H}), 1.43-1.35(\mathrm{~m}, 1 \mathrm{H}) .{ }^{13} \mathbf{C}$ NMR (126 MHz, $\mathbf{C D C l}_{3}$, mixture of rotamers) $\delta 156.94,142.32,113.51,113.13,81.50,79.75,65.39,64.05,52.49,52.15,42.69$, $37.23,36.79$, 28.63. IR (neat): 3425, 2974, 2882, 1675, 1403, 1159,1108, 878, 767, $562 \mathrm{~cm}^{-1}$. HRMS (EI): exact mass calculated for $[\mathrm{M}-\mathrm{Boc}+\mathrm{H}]^{+}\left(\mathrm{C}_{8} \mathrm{H}_{13} \mathrm{NO}\right)$ requires $m / z$ 139.09917, found $m / z 139.09958$.

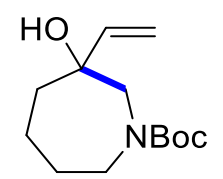

tert-butyl 3-hydroxy-3-vinylazepane-1-carboxylate (13)

The titled compound was synthesized by vinylation of tert-butyl 3-oxoazepane-1-carboxylate. ${ }^{5}$

To an oven-dried $25-\mathrm{mL}$ round-bottomed flask, charged with a stir bar, was added vinylmagnesium chloride (3.52 mmol, 3.00 eq., $2.4 \mathrm{~mL}, 1.6 \mathrm{M}$ THF solution) under inert atmosphere. The solution was cooled to $0{ }^{\circ} \mathrm{C}$, and a THF solution of tert-butyl 3-oxoazepane-1-carboxylate $(1.17 \mathrm{mmol}$, 1.00 eq., $250 \mathrm{mg}, 5 \mathrm{~mL} \mathrm{THF}$ ) was added in dropwise. The mixture was allowed to warm to r.t. and stirred for $12 \mathrm{~h}$. Afterwards, the reaction was quenched with sat. aq. $\mathrm{NH}_{4} \mathrm{Cl}(10 \mathrm{~mL})$, extracted in $\mathrm{Et}_{2} \mathrm{O}$ (15 mL, three times). The combined organic layers were washed with sat. aq. $\mathrm{NaCl}(15 \mathrm{~mL})$, dried over anhydrous $\mathrm{MgSO}_{4}$, filtered, and concentrated to a small volume. This crude was purified by silica gel flash column chromatography ( $10 \%$ to $30 \%$ EtOAc in hexanes) to obtain the titled 
compound (200 mg, 70\% yield) as a colorless oil which slowly solidified to a white solid. ${ }^{\mathbf{1}} \mathbf{H}$ NMR $\left(500 \mathrm{MHz}, \mathbf{C D C l}_{3}\right.$, mixture of rotamers) $\delta$ 5.98-5.82 (m, 1H), 5.45-5.29 (m, 1H), $5.09(\mathrm{~d}, J=$ $10.7 \mathrm{~Hz}, 1 \mathrm{H}), 4.18(\mathrm{~s}, 1 \mathrm{H}), 3.95-3.57(\mathrm{~m}, 2 \mathrm{H}), 3.22-2.84(\mathrm{~m}, 2 \mathrm{H}), 1.93-1.57(\mathrm{~m}, 6 \mathrm{H}), 1.48(\mathrm{~s}$, 9H). ${ }^{13} \mathbf{C}$ NMR (126 MHz, $\mathbf{C D C l}_{3}$, mixture of rotamers) $\delta 158.48,142.87,112.99,80.50,76.49$, 56.79, 48.77, 40.72, 29.04, 28.54, 21.09. IR (neat): 3353, 2961, 2931, 2864, 1649, 1483, 1442, $1419,1150,919,873,779 \mathrm{~cm}^{-1}$. HRMS (ESI): exact mass calculated for $[\mathrm{M}+\mathrm{Na}]^{+}\left(\mathrm{C}_{13} \mathrm{H}_{23} \mathrm{NNaO}_{3}\right)$ requires $m / z 264.15701$, found $m / z 264.15710$.

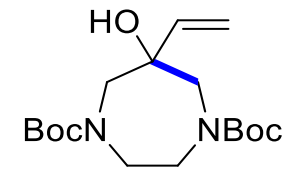

di-tert-butyl 6-hydroxy-6-vinyl-1,4-diazepane-1,4-dicarboxylate (14)

The titled compound was synthesized by a three-step sequence from known compound 1,4dibenzyl-1,4-diazepan-6-ol. ${ }^{11}$ 1,4-Dibenzyl-1,4-diazepan-6-ol was first converted to di-tert-butyl 6-hydroxy-1,4-diazepane-1,4-dicarboxylate under a one-pot reduction/Boc protection condition modified based on literature. ${ }^{12}$ The oxidation of di-tert-butyl 6-hydroxy-1,4-diazepane-1,4dicarboxylate by Dess-Martin periodinane delivered di-tert-butyl 6-oxo-1,4-diazepane-1,4dicarboxylate. ${ }^{9}$ The titled compound was then furnished by a final vinylation ${ }^{5}$ of di-tert-butyl 6 oxo-1,4-diazepane-1,4-dicarboxylate.

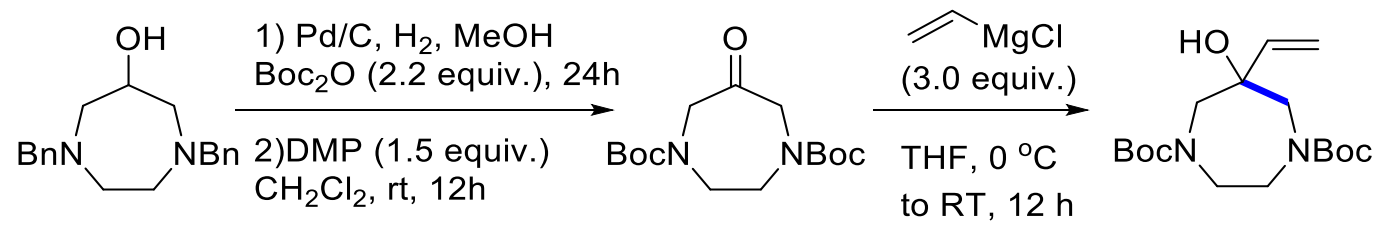

An oven-dried 50-mL round-bottomed flask, charged with a stir bar, was added 1,4-dibenzyl-1,4diazepan-6-ol (0.675 mmol, 1.00 eq., $200 \mathrm{mg})$, di-tert-butyl decarbonate (1.48 mmol, 2.20 eq., $0.350 \mathrm{~mL})$ and palladium on carbon $(71.8 \mathrm{mg}, 10 \mathrm{wt} \%)$. The flask was sealed and evacuated and refilled with nitrogen gas for three times. Then, $\mathrm{MeOH}(25 \mathrm{~mL})$ was added. A hydrogen gas balloon was connected to the flask, and the evacuation and hydrogen gas refilling process was repeated for three times while stirring. The resulting mixture was stirred at r.t. for another $24 \mathrm{~h}$ under an atmospheric-pressure hydrogen. Then, the reaction mixture was filtered through a plug of Celite. The filter cake was rinsed by $\mathrm{CH}_{2} \mathrm{Cl}_{2}(10 \mathrm{~mL}$, two times). The collected filtrate was concentrated under reduced pressure at $45{ }^{\circ} \mathrm{C}$ to afford di-tert-butyl 6-hydroxy-1,4-diazepane-1,4dicarboxylate (200 mg, 94\% yield) as a white solid. No further purification was conducted, and the crude material was carried on to next step.

An oven-dried 25-mL round-bottomed flask, charged with a stir bar, was added di-tert-butyl 6hydroxy-1,4-diazepane-1,4-dicarboxylate $(0.630 \mathrm{mmol}, 1.00$ eq., $200 \mathrm{mg})$ and Dess-Martin periodinane ( $0.950 \mathrm{mmol}, 1.50$ eq., $402 \mathrm{mg}$ ). Under inert atmosphere, $\mathrm{CH}_{2} \mathrm{Cl}_{2}(3 \mathrm{~mL})$ was added. The solution was stirred at r.t. for $24 \mathrm{~h}$ and was then. diluted by $\mathrm{Et}_{2} \mathrm{O}(10 \mathrm{~mL})$. Quenched by $10 \%$ aq. $\mathrm{Na}_{2} \mathrm{~S}_{2} \mathrm{O}_{3}(40 \mathrm{~mL})$, the mixture was stirred for 30 minutes. After layer separation, the organic layer was washed with $5 \%$ aq. $\mathrm{Na}_{2} \mathrm{CO}_{3}(10 \mathrm{~mL})$, dried over anhydrous $\mathrm{MgSO}_{4}$, filtered and concentrated to afford di-tert-butyl 6-oxo-1,4-diazepane-1,4-dicarboxylate (189 $\mathrm{mg}, 95 \%$ yield) as a white solid. No further purification was conducted, and the crude material was carried on to 
next step. Spectral data of the crude match with literature values. ${ }^{13}$

To an oven-dried 10-mL round-bottomed flask, charged with a stir bar, was added vinylmagnesium chloride (1.86 mmol, 3.00 eq., 1.1 mL, 1.6 M THF solution) under inert atmosphere. The solution was cooled to $0{ }^{\circ} \mathrm{C}$, and a THF solution of di-tert-butyl 6-oxo-1,4-diazepane-1,4-dicarboxylate (0.620 mmol, 1.00 eq., $195 \mathrm{mg}, 3 \mathrm{~mL}$ THF) was added in dropwise. The mixture was allowed to warm to r.t. and stirred for $12 \mathrm{~h}$. Afterwards, the reaction was quenched with sat. aq. $\mathrm{NH}_{4} \mathrm{Cl}(20$ $\mathrm{mL})$, extracted in $\mathrm{Et}_{2} \mathrm{O}$ (15 mL, three times). The combined organic layers were washed with sat. aq. $\mathrm{NaCl}(15 \mathrm{~mL})$, dried over anhydrous $\mathrm{MgSO}_{4}$, filtered, and concentrated to a small volume. This crude was purified by silica gel flash column chromatography $(10 \%$ to $30 \%$ EtOAc in hexanes) to obtain the titled compound (164 mg, 77\% yield) as a colorless oil which slowly solidified to a white solid.

${ }^{1} \mathbf{H}$ NMR (500 MHz, $\mathbf{C D C l}_{3}$, mixture of rotamers) $\delta 5.95(\mathrm{dd}, J=17.1,10.7 \mathrm{~Hz}, 1 \mathrm{H}), 5.49(\mathrm{~d}, J$ $=17.5 \mathrm{~Hz}, 1 \mathrm{H}), 5.15(\mathrm{dd}, J=10.7,1.7 \mathrm{~Hz}, 1 \mathrm{H}), 4.44-2.87(\mathrm{~m}, 8 \mathrm{H}), 1.48(\mathrm{br}, 18 \mathrm{H}) .{ }^{13} \mathbf{C}$ NMR (126 $\mathbf{M H z} \mathbf{C D C l}_{3}$, mixture of rotamers) $\delta 157.78,156.58,140.50,114.28,113.79,81.18,80.64$, 77.55, 57.93, 57.01, 49.54, 49.25, 28.50. IR (neat): 3422, 2969, 2928, 1692, 1661, 1483, 1408, 1364, 1066, 768, $625 \mathrm{~cm}^{-1}$. HRMS (ESI): exact mass calculated for $[\mathrm{M}+\mathrm{Na}]^{+}\left(\mathrm{C}_{17} \mathrm{H}_{30} \mathrm{~N}_{2} \mathrm{NaO}_{5}\right)$ requires $\mathrm{m} / \mathrm{z} 365.20469$, found $\mathrm{m} / \mathrm{z} 365.20425$.

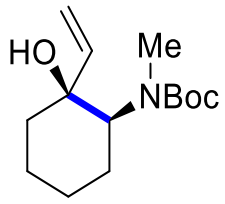

tert-butyl ((1S* $\left.2 S^{*}\right)$-2-hydroxy-2-vinylcyclohexyl)(methyl)carbamate (15)

The titled compound was synthesized by vinylation of tert-butyl methyl(2oxocyclohexyl)carbamate, which was synthesized following a literature procedure. ${ }^{5,14}$

To an oven-dried $25-\mathrm{mL}$ round-bottomed flask, charged with a stir bar, was added vinylmagnesium chloride ( $8.18 \mathrm{mmol}, 2.00$ eq., $5.5 \mathrm{~mL}, 1.6 \mathrm{M}$ THF solution) under inert atmosphere. The solution was cooled to $0{ }^{\circ} \mathrm{C}$, and a THF solution of tert-butyl methyl(2-oxocyclohexyl)carbamate (4.09 mmol, 1.00 eq., $930 \mathrm{mg}, 10 \mathrm{~mL}$ THF) was added in dropwise. The mixture was allowed to warm to r.t. and stirred for $12 \mathrm{~h}$. Afterwards, the reaction was quenched with sat. aq. $\mathrm{NH}_{4} \mathrm{Cl}(20 \mathrm{~mL})$, extracted in $\mathrm{Et}_{2} \mathrm{O}(20 \mathrm{~mL}$, three times). The combined organic layers were washed with sat. aq. $\mathrm{NaCl}(20 \mathrm{~mL})$, dried over anhydrous $\mathrm{MgSO}_{4}$, filtered, and concentrated to a small volume. This crude was purified by silica gel flash column chromatography (7\% to $60 \%$ EtOAc in hexanes) to obtain the titled compound ( $413 \mathrm{mg}, 40 \%$ yield) as a single diastereomer. The minor diastereomer, which had a slightly lower $\mathrm{R}_{\mathrm{f}}$, was contaminated with impurities and thus was not recovered. ${ }^{1} \mathbf{H}$ NMR (500 MHz, DMSO- $\left.\boldsymbol{d}_{\mathbf{6}} \mathbf{1 2 0}^{\circ} \mathrm{C}\right) \delta 5.89(\mathrm{ddd}, J=17.4,10.9,1.9 \mathrm{~Hz}, 1 \mathrm{H}), 5.34-5.19(\mathrm{~m}, 1 \mathrm{H})$, $5.02-4.88(\mathrm{~m}, 1 \mathrm{H}), 4.10(\mathrm{~s}, 1 \mathrm{H}), 3.81(\mathrm{dd}, J=12.7,3.6 \mathrm{~Hz}, 1 \mathrm{H}), 2.79(\mathrm{~s}, 3 \mathrm{H}), 2.05(\mathrm{qd}, J=12.9$, $4.2 \mathrm{~Hz}, 1 \mathrm{H}), 1.85-1.73(\mathrm{~m}, 1 \mathrm{H}), 1.66$ (dtd, $J=12.7,8.4,3.2 \mathrm{~Hz}, 1 \mathrm{H}), 1.58-1.50(\mathrm{~m}, 1 \mathrm{H}), 1.50-$ 1.24 (m, 12H). ${ }^{13} \mathbf{C}$ NMR (126 MHz, DMSO-d $\left.6 \mathbf{~}^{120}{ }^{\circ} \mathbf{C}\right) \delta 154.10,144.25,110.56,79.52,73.21$, 54.56, 38.13, 36.65, 27.55, 24.98, 24.50, 19.66. IR (neat): 3369, 2925, 2859, 1663, 1478, 1398, 1170, 1132, 970, 951, 767, $609 \mathrm{~cm}^{-1}$. HRMS (ESI): exact mass calculated for $[\mathrm{M}+\mathrm{Na}]^{+}$ $\left(\mathrm{C}_{14} \mathrm{H}_{25} \mathrm{NNaO}_{3}\right)$ requires $m / z$ 278.17266, found $m / z 278.17249$. 


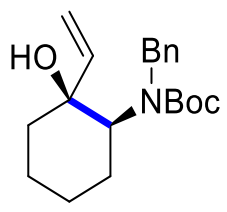

tert-butyl benzyl((1S*,2S*)-2-hydroxy-2-vinylcyclohexyl)carbamate (16)

The titled compound was synthesized by vinylation of tert-butyl benzyl(2oxocyclohexyl)carbamate, which was synthesized following a literature procedure. ${ }^{5,15}$

To an oven-dried 50-mL round-bottomed flask, charged with a stir bar, was added vinylmagnesium chloride ( $9.60 \mathrm{mmol}, 2.10$ eq., $6.0 \mathrm{~mL}, 1.6 \mathrm{M}$ THF solution) under inert atmosphere. The solution was cooled to $0{ }^{\circ} \mathrm{C}$, and a THF solution of tert-butyl tert-butyl benzyl(2-oxocyclohexyl)carbamate (4.61 mmol, 1.00 eq., $1.40 \mathrm{~g}, 20 \mathrm{~mL}$ THF) was added in dropwise. The mixture was allowed to warm to room temperature and stirred for $12 \mathrm{~h}$. Afterwards, the reaction was quenched with sat. aq. $\mathrm{NH}_{4} \mathrm{Cl}(20 \mathrm{~mL})$, extracted in $\mathrm{Et}_{2} \mathrm{O}(20 \mathrm{~mL}$, three times $)$. The combined organic layers were washed with sat. aq. $\mathrm{NaCl}(20 \mathrm{~mL})$, dried over anhydrous $\mathrm{MgSO}_{4}$, filtered, and concentrated to a small volume. This crude was purified by silica gel flash column chromatography (7\% to $60 \%$ EtOAc in hexanes) to obtain the titled compound ( $242 \mathrm{mg}, 16 \%$ yield) as a white solid. ${ }^{1} \mathbf{H}$ NMR $\left(\mathbf{5 0 0}\right.$ MHz, DMSO-d $\left.\mathbf{6} \mathbf{1 2 0}^{\circ} \mathrm{C}\right) \delta 7.37-7.10(\mathrm{~m}, 5 \mathrm{H}), 5.93(\mathrm{dd}, J=17.3,10.8 \mathrm{~Hz}, 1 \mathrm{H}), 5.29(\mathrm{dd}, J$ $=17.2,2.1 \mathrm{~Hz}, 1 \mathrm{H}), 4.98(\mathrm{dd}, J=10.7,2.1 \mathrm{~Hz}, 1 \mathrm{H}), 4.65(\mathrm{~d}, J=16.3 \mathrm{~Hz}, 1 \mathrm{H}), 4.53-4.35(\mathrm{~m}, 2 \mathrm{H})$, $3.87(\mathrm{~d}, J=10.5 \mathrm{~Hz}, 1 \mathrm{H}), 2.08-1.89(\mathrm{~m}, 1 \mathrm{H}), 1.77-1.44(\mathrm{~m}, 4 \mathrm{H}), 1.42-1.12(\mathrm{~m}, 10 \mathrm{H}) .{ }^{13} \mathbf{C}$ NMR (126 MHz, DMSO-d $\left.\mathbf{d}_{\mathbf{6}} \mathbf{1 2 0}^{\circ} \mathrm{C}\right) \delta 152.44,144.29,127.03,126.12,125.31,110.84,74.85,69.76$, 60.70, 48.15, 38.19, 27.37, 25.64, 25.11, 19.54. IR (neat): 3422, 2975, 2931, 2856, 2361, 2338, 1681, 1465, 1365, 1158, 970, 859, $569 \mathrm{~cm}^{-1}$. HRMS (ESI): exact mass calculated for [M+Na] $\left(\mathrm{C}_{20} \mathrm{H}_{29} \mathrm{NNaO}_{3}\right)$ requires $m / z$ 354.20396, found $m / z 354.20383$. 


\section{Synthesis of Starting Materials for $\mathbf{n}+1$ Chemistry}

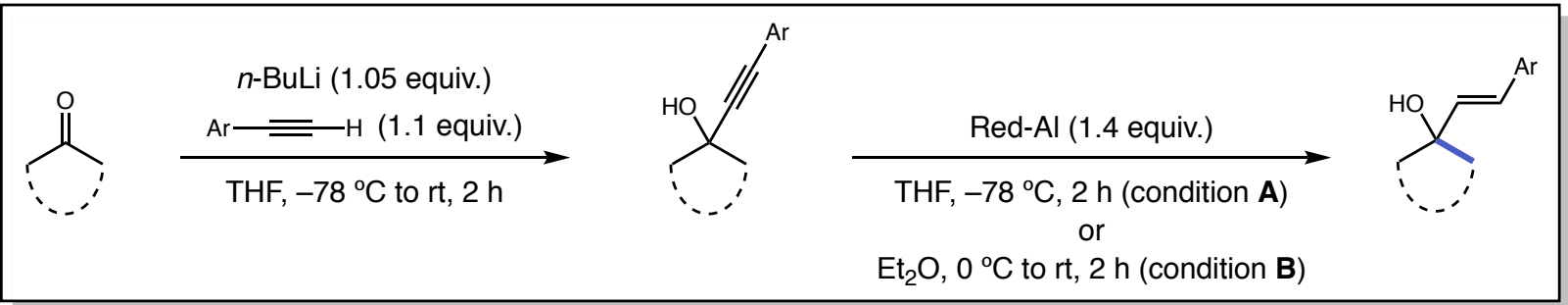

The starting materials for $\mathrm{n}+1$ ring expansion were synthesized via alkynylation of ketone, followed by reduction of the corresponded $\alpha$-alkynyl alcohol. Characterizations of $\alpha$-alkynyl alcohols are iterated first.
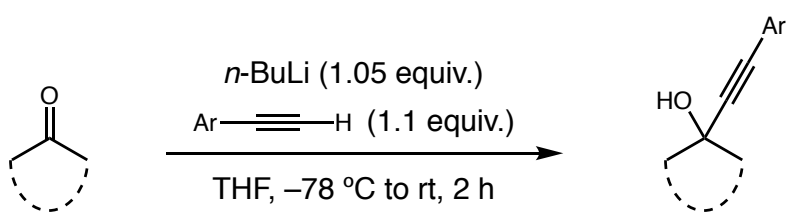

\section{General procedure for the alkynylation of ketone: ${ }^{16}$}

To an oven-dried round-bottomed flask, charged with a stir bar, is added a THF solution of arylacetylene (1.10 eq. in $0.35 \mathrm{M}$ THF). To the solution was added $n$-BuLi (1.05 eq., $1.6 \mathrm{M}$ in hexanes) at $-78{ }^{\circ} \mathrm{C}$. The mixture was stirred at same temperature for $30 \mathrm{~min}$, and was then dropwise added a THF solution of ketone (1.00 eq. in $0.3 \mathrm{M} \mathrm{THF}$ ). The resulting mixture was allowed to warm to room temperature and stirred for another $2 \mathrm{~h}$. Afterwards, the reaction was quenched with sat. aq. $\mathrm{NH}_{4} \mathrm{Cl}(20 \mathrm{~mL})$, extracted in $\mathrm{CH}_{2} \mathrm{Cl}_{2}(20 \mathrm{~mL}$, three times). The combined organic layers were washed with sat. aq. $\mathrm{NaCl}(20 \mathrm{~mL})$, dried over $\mathrm{MgSO}_{4}$, filtered, and concentrated to a small volume. This crude was purified by silica gel flash column chromatography ( $2 \%$ to $15 \%$ EtOAc in hexanes, unless otherwise noted) in hexanes to obtain the $\alpha$-alkynyl alcohol.

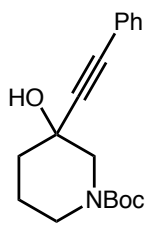

\section{tert-butyl 3-hydroxy-3-(phenylethynyl)piperidine-1-carboxylate}

Prepared following the general procedure with phenylacetylene and tert-butyl 3-oxopiperidine-1carboxylateto afford the titled compound as a white solid $(2.55 \mathrm{~g}, 85 \%)$. ${ }^{1} \mathbf{H}$ NMR (500 MHz, $\mathbf{C D C l}_{3}$, mixture of rotamers) $\delta 7.42-7.38(\mathrm{~m}, 2 \mathrm{H}), 7.31-7.26(\mathrm{~m}, 3 \mathrm{H}), 3.84-3.07(\mathrm{~m}, 4 \mathrm{H}), 2.65$ (br, 1H), 2.04-1.58 (m, 4H), $1.43(\mathrm{~s}, 9 \mathrm{H}) .{ }^{13} \mathbf{C ~ N M R ~ ( 1 2 6 ~ M H z , ~} \mathbf{C D C l}_{3}$, mixture of rotamers) $\delta$ $155.46,154.93,131.86,128.52$, 128.33, 122.55, 90.73, 84.74, 79.96, 66.50, 54.86, 54.10, 44.56, 43.17, 38.33, 37.54, 28.51, 22.06. IR (neat): 3401, 2922, 2857, 1667, 1428, 1365, 1267, 1151, 899, $758 \mathrm{~cm}^{-1}$. HRMS (ESI): exact mass calculated for $[\mathrm{M}+\mathrm{H}]^{+}\left(\mathrm{C}_{18} \mathrm{H}_{24} \mathrm{NO}_{3}\right)$ requires $\mathrm{m} / \mathrm{z}$ 302.17507 , found $m / z 302.17529$. 


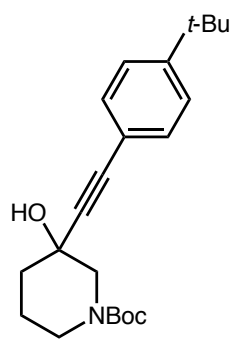

tert-butyl 3-((4-(tert-butyl)phenyl)ethynyl)-3-hydroxypiperidine-1-carboxylate

Prepared following the general procedure with 4-tert-butylphenylacetylene and tert-butyl 3oxopiperidine-1-carboxylateto afford the titled compound as a white solid (932 $\mathrm{mg}, 33 \%)$. ${ }^{\mathbf{1}} \mathbf{H}$ NMR (500 MHz, CDCl 3 , mixture of rotamers) $\delta 7.34(\mathrm{~d}, J=7.9 \mathrm{~Hz}, 2 \mathrm{H}), 7.31(\mathrm{~d}, J=7.9 \mathrm{~Hz}$, 2H), 3.78-3.29 (m, 4H), 2.43 (br, 1H), 2.01-1.57 (m, 4H), $1.44(\mathrm{~s}, 9 \mathrm{H}), 1.29$ (s, 9H). ${ }^{13} \mathbf{C}$ NMR (126 MHz, CDCl $\mathbf{3}$, mixture of rotamers) $\delta 154.94,151.86,131.60,125.36,119.44,89.91,84.98$, 79.97, 66.55, 54.91, 54.17, 44.59, 43.22, 38.33, 37.50, 34.90, 31.28, 28.55, 21.97. IR (neat): 3405, 2953, 1678, 1440, 1364, 1269, 1156, 1074, 833, $759 \mathrm{~cm}^{-1}$. HRMS (ESI): exact mass calculated for $[\mathrm{M}+\mathrm{Na}]^{+}\left(\mathrm{C}_{22} \mathrm{H}_{31} \mathrm{NNaO}_{3}\right)$ requires $m / z$ 380.21961, found $m / z$ 380.21948.

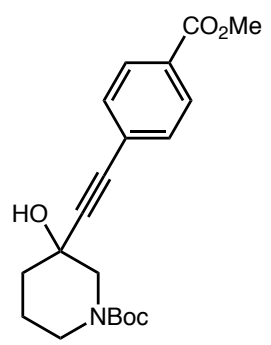

tert-butyl 3-hydroxy-3-((4-(methoxycarbonyl)phenyl)ethynyl)piperidine-1-carboxylate

The titled compound was synthesized via Sonogashira coupling of tert-butyl 3-ethynyl-3hydroxypiperidine-1-carboxylate with methyl 4-bromobenzoate following a literature procedure. ${ }^{17}$

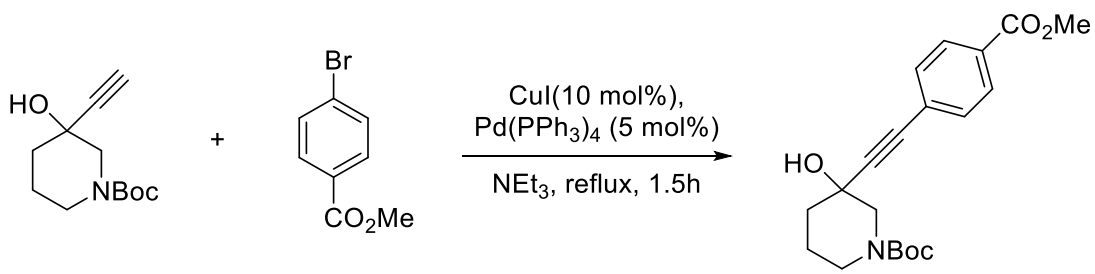

To an oven-dried 50-mL three-necked round-bottomed flask was charged with tert-butyl 3ethynyl-3-hydroxypiperidine-1-carboxylate (6.00 mmol, 1.00 eq., $1.35 \mathrm{~g}), \mathrm{Pd}\left(\mathrm{PPh}_{3}\right)_{4}(0.30 \mathrm{mmol}$, $5 \mathrm{~mol} \%, 347 \mathrm{mg})$, and copper(I) iodide $(0.60 \mathrm{mmol}, 10 \mathrm{~mol} \%, 114 \mathrm{mg})$ followed by triethylamine $(38 \mathrm{~mL})$. The flask was then purged with $\mathrm{N}_{2}$ for $10 \mathrm{~min}$ before methyl 4-bromobenzoate $(9.00$ mmol, 1.50 eq., $1.94 \mathrm{~g}$ ) was introduced. Purging with $\mathrm{N}_{2}$ continued for 15 min and the resulting mixture was refluxed for $1.5 \mathrm{~h}$. After cooling, the reaction mixture was filtered through a layer of Celite and the cake was washed with $\mathrm{CH}_{2} \mathrm{Cl}_{2}$. The filtrate was concentrated in vacuo and the crude residue was purified by silica gel flash column chromatography (5\% to 50\% EtOAc in hexanes) to furnish the titled compound (1.81g, 84\%) as a pale yellow solid. ${ }^{1} \mathbf{H}$ NMR (500 $\mathbf{~ M H z , ~} \mathbf{C D C l}_{3}$, mixture of rotamers) $\delta 7.92(\mathrm{~d}, J=8.4 \mathrm{~Hz}, 2 \mathrm{H}), 7.42(\mathrm{~d}, J=8.4 \mathrm{~Hz}, 2 \mathrm{H}), 3.88(\mathrm{~s}, 3 \mathrm{H}), 3.81(\mathrm{~m}$, 1H), 3.67 (br, 1H), 3.55-3.06 (m, 3H), $2.02(\mathrm{~m}, 1 \mathrm{H}), 1.86-1.52(\mathrm{~m}, 3 \mathrm{H}), 1.39$ (s, 9H). ${ }^{13} \mathbf{C ~ N M R}$ (126 MHz, $\mathbf{C D C l}_{3}$, mixture of rotamers) $\delta 166.60,155.31,154.82,131.73,129.66,129.45$, $127.35,93.88,83.91,80.01,66.45,54.71,53.95,52.33,44.50,43.14,38.25,37.49,28.47,22.13$. 
IR (neat): 3391, 2949, 2859, 1722, 1664, 1428, 1271, 1150, 1107, 972, 858, $768 \mathrm{~cm}^{-1}$. HRMS (ESI): exact mass calculated for $[\mathrm{M}+\mathrm{Na}]^{+}\left(\mathrm{C}_{20} \mathrm{H}_{25} \mathrm{NNaO}_{5}\right)$ requires $\mathrm{m} / \mathrm{z} 382.16249$, found $\mathrm{m} / \mathrm{z}$ 382.16226 .

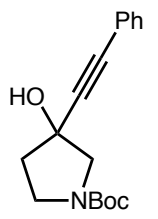

tert-butyl 3-hydroxy-3-(phenylethynyl)pyrrolidine-1-carboxylate

Prepared following the general procedure with phenylacetylene and tert-butyl 3-oxopyrrolidine1-carboxylateto afford the titled compound as a white solid (2.19 g, 76\%). ${ }^{1} \mathbf{H}$ NMR (500 MHz, $\mathbf{C D C l}_{3}$, mixture of rotamers) $\delta 7.42-7.40(\mathrm{~m}, 2 \mathrm{H}), 7.33-7.28(\mathrm{~m}, 3 \mathrm{H}), 3.74-3.51(\mathrm{~m}, 4 \mathrm{H}), 3.01$ $(\mathrm{m}, 1 \mathrm{H}), 2.28-2.21(\mathrm{~m}, 2 \mathrm{H}), 1.46(\mathrm{~s}, 9 \mathrm{H}) .{ }^{13} \mathbf{C}$ NMR $\left(\mathbf{1 2 6} \mathbf{~ M H z}, \mathbf{C D C l}_{3}\right.$, mixture of rotamers) $\delta$ $154.65,154.55,131.83,131.79,128.76,128.73,128.44,128.41,122.25,122.20,89.08,84.73$, 79.80, 72.30, 71.48, 59.56, 59.31, 44.66, 44.26, 40.44, 40.06, 28.61. IR (neat): 3367, 2979, 2896, 1662, 1422, 1239, 1133, 936, 875, $762 \mathrm{~cm}^{-1}$. HRMS (ESI): exact mass calculated for $[\mathrm{M}+\mathrm{H}]^{+}$ $\left(\mathrm{C}_{17} \mathrm{H}_{22} \mathrm{NO}_{3}\right)$ requires $m / z 288.15942$, found $m / z 288.15931$.

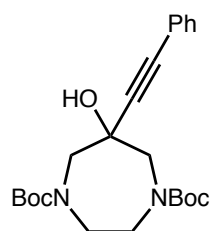

di-tert-butyl 6-hydroxy-6-(phenylethynyl)-1,4-diazepane-1,4-dicarboxylate

Prepared following the general procedure with phenylacetylene and di-tert-butyl 6-oxo-1,4diazepane-1,4-dicarboxylate afford the titled compound as a pale yellow solid (693 $\mathrm{mg}, 82 \%)$. ${ }^{1} \mathbf{H}$ NMR (400 MHz, DMSO- $\left.\boldsymbol{d}_{\mathbf{6}} \mathbf{1 2 0}^{\circ} \mathrm{C}\right) \delta$ 7.39-7.31 (m, 5H), $5.38(\mathrm{~s}, 1 \mathrm{H}), 4.04(\mathrm{~d}, J=14.0 \mathrm{~Hz}, 2 \mathrm{H})$, 3.73-3.66 (m, 2H), 3.37-3.28 (m, 2H), 3.30 (d, $J=14.0 \mathrm{~Hz}, 2 \mathrm{H}), 1.38(\mathrm{~s}, 18 \mathrm{H}) .{ }^{13} \mathbf{C}$ NMR (101 MHz, DMSO- $\left.\boldsymbol{d}_{\mathbf{6}}, \mathbf{1 2 0}^{\circ} \mathrm{C}\right) \delta 154.07,130.56,127.52,127.45,122.28,91.03,83.75,78.32,69.36$, 54.84, 45.49, 27.46. IR (neat): 3391, 2974, 2930, 1667, 1406, 1364, 1244, 1133, 1047, 865, 756 $\mathrm{cm}^{-1}$. HRMS (ESI): exact mass calculated for $[\mathrm{M}+\mathrm{Na}]^{+}\left(\mathrm{C}_{23} \mathrm{H}_{32} \mathrm{~N}_{2} \mathrm{NaO}_{5}\right)$ requires $m / z 439.22034$, found $m / z 439.22012$.

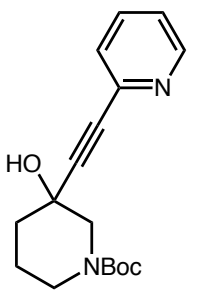

tert-butyl 3-hydroxy-3-(pyridin-2-ylethynyl)piperidine-1-carboxylate

The titled compound was synthesized via alkynylation of tert-butyl 3-oxopiperidine-1-carboxylate with 2-ethynylpyridine using LiHMDS as a base following a literature procedure. ${ }^{18}$ 


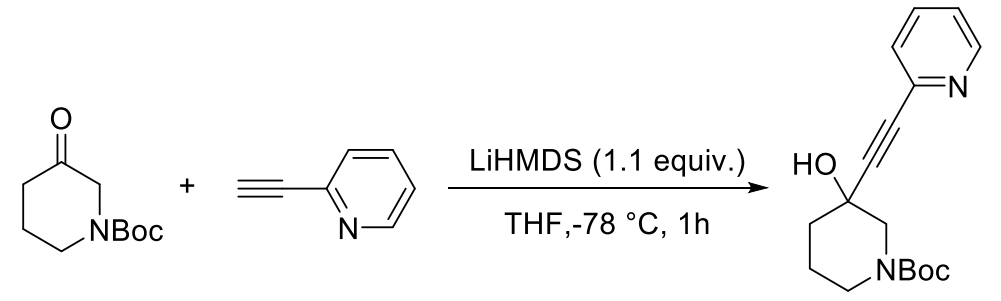

To an oven-dried 50-mL round-bottomed flask, charged with a stir bar, was added lithium bis(trimethylsilyl)amide (4.42 mmol, 1.10 eq., $739 \mathrm{mg}$ ) in a glove box and was then added THF $(20 \mathrm{~mL})$. At $-78^{\circ} \mathrm{C}, 2$-ethynylpyridine $(4.42 \mathrm{mmol}, 1.10$ eq., $0.45 \mathrm{~mL})$ was added dropwise by a syringe. The resulting mixture was stirred at same temperature for 20 min to afford a yellow suspension. At $-78{ }^{\circ} \mathrm{C}$, a THF solution of tert-butyl 3-oxopiperidine-1-carboxylate (4.02 mmol, 1.00 eq., $0.800 \mathrm{~g}$ in $5 \mathrm{~mL} \mathrm{THF}$ ) was added dropwise. The mixture was stirred at same temperature for another $20 \mathrm{~min}$. Afterwards, the reaction was quenched with sat. aq. $\mathrm{NH}_{4} \mathrm{Cl}(20 \mathrm{~mL})$, extracted in $\mathrm{Et}_{2} \mathrm{O}(20 \mathrm{~mL}$, three times). The combined organic layers were washed with sat. aq. $\mathrm{NaCl}(20$ $\mathrm{mL}$ ), dried over anhydrous $\mathrm{MgSO}_{4}$, filtered, and concentrated to a small volume. This crude was purified by silica gel flash column chromatography (10\% to $70 \%$ EtOAc in hexanes) to obtain the

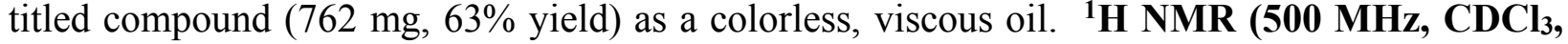
mixture of rotamers) $\delta 8.56(\mathrm{~d}, J=4.6 \mathrm{~Hz}, 1 \mathrm{H}), 7.63(\mathrm{td}, J=7.7,1.9 \mathrm{~Hz}, 1 \mathrm{H}), 7.41(\mathrm{~d}, J=7.9$ $\mathrm{Hz}, 1 \mathrm{H}), 7.25-7.19(\mathrm{~m}, 1 \mathrm{H}), 3.89-2.86(\mathrm{~m}, 4 \mathrm{H}), 2.14-1.88(\mathrm{~m}, 2 \mathrm{H}), 1.90-1.59(\mathrm{~m}, 2 \mathrm{H}), 1.43(\mathrm{~s}$, 9H). ${ }^{13} \mathbf{C}$ NMR (126 MHz, $\mathbf{C D C l}_{3}$, mixture of rotamers) $\delta 155.01,149.99,142.78,136.34$, $127.50,123.22,83.94,80.02,66.33,60.55,55.57,53.87,44.66,43.24,37.84,28.53,21.80$. IR (neat) 3370, 2929, 2857, 1687, 1582, 1425, 1241, 1148, 974, $777 \mathrm{~cm}^{-1}$. HRMS (ESI): exact mass calculated for $[\mathrm{M}+\mathrm{H}]^{+}\left(\mathrm{C}_{17} \mathrm{H}_{23} \mathrm{~N}_{2} \mathrm{O}_{3}\right)$ requires $m / z$ 303.17032, found $m / z$ 303.17051.

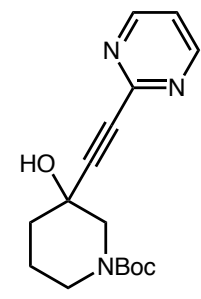

tert-butyl 3-hydroxy-3-(pyrimidin-2-ylethynyl)piperidine-1-carboxylate

The titled compound was synthesized via alkynylation of tert-butyl 3-oxopiperidine-1-carboxylate with 2-ethynylpyrimidine using LiHMDS as a base following a literature procedure. ${ }^{18}$

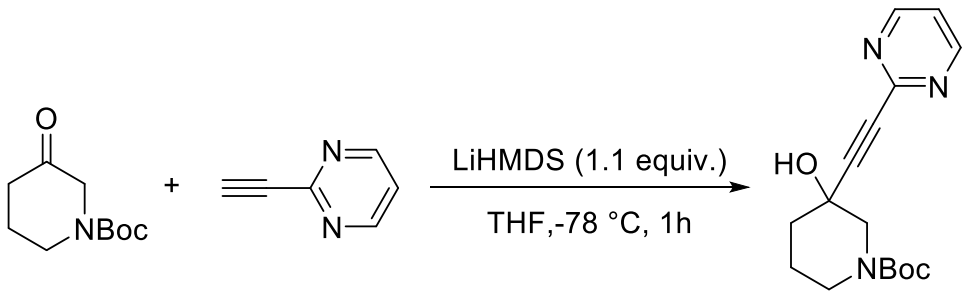

To an oven-dried 50-mL round-bottomed flask, charged with a stir bar, was added lithium bis(trimethylsilyl)amide (3.86 mmol, 1.10 eq., $647 \mathrm{mg}$ ) in a glove box and was then added THF $(20 \mathrm{~mL})$. At $-78^{\circ} \mathrm{C}$, a THF solution of 2-ethynylpyrimidine $(3.86 \mathrm{mmol}, 1.10$ eq., $402 \mathrm{mg}$ in $3 \mathrm{~mL}$ THF) was added dropwise by a syringe. The resulting mixture was stirred at same temperature for 45 min to afford a yellow suspension. At $-78^{\circ} \mathrm{C}$, a THF solution of tert-butyl 3-oxopiperidine-1carboxylate (3.51 mmol, 1.00 eq., $700 \mathrm{mg}$ in $5 \mathrm{~mL}$ THF) was added dropwise. The mixture was 
stirred at same temperature for another $1 \mathrm{~h}$. Afterwards, the reaction was quenched with sat. aq. $\mathrm{NH}_{4} \mathrm{Cl}(20 \mathrm{~mL})$, extracted in $\mathrm{Et}_{2} \mathrm{O}(20 \mathrm{~mL}$, three times). The combined organic layers were washed with sat. aq. $\mathrm{NaCl}(20 \mathrm{~mL})$, dried over anhydrous $\mathrm{MgSO}_{4}$, filtered, and concentrated to a small volume. This crude was purified by silica gel flash column chromatography (7\% to 100\% EtOAc in hexanes) to obtain the titled compound ( $730 \mathrm{mg}, 69 \%$ yield) as a white solid. . ${ }^{1} \mathbf{H}$ NMR (500 MHz, $\mathbf{C D C l}_{3}$, mixture of rotamers) $8.72(\mathrm{~d}, J=5.0 \mathrm{~Hz}, 2 \mathrm{H}), 7.24(\mathrm{t}, J=5.0 \mathrm{~Hz}, 1 \mathrm{H}), 4.05-2.30$ (m, 5H), $2.03(\mathrm{~s}, 2 \mathrm{H}), 1.89-1.77(\mathrm{~m}, 1 \mathrm{H}), 1.68(\mathrm{~s}, 1 \mathrm{H}), 1.44(\mathrm{~s}, 9 \mathrm{H}) .{ }^{13} \mathbf{C}$ NMR (126 MHz, CDCl $\mathbf{3}$, mixture of rotamers) $\delta 157.40,155.03,152.67,120.24,89.59,83.29,80.17,66.23,54.48,44.77$, 43.33, 37.47, 28.52, 21.37. IR (neat): 3244, 2980, 2946, 2864, 1683, 1565, 1476, 1408, 1241, 1072, 905, $649 \mathrm{~cm}^{-1}$. HRMS (ESI): exact mass calculated for $[\mathrm{M}+\mathrm{H}]^{+}\left(\mathrm{C}_{16} \mathrm{H}_{22} \mathrm{~N}_{3} \mathrm{O}_{3}\right)$ requires $m / z$ 304.16557, found $\mathrm{m} / \mathrm{z} 304.16559$.

\section{3-(phenylethynyl)tetrahydrofuran-3-ol}

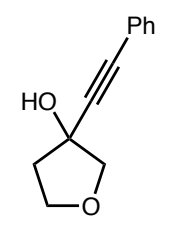

Prepared following the general procedure with phenylacetylene and tetrahydrofuran-3-one using $3 \%$ to $23 \% \mathrm{Et}_{2} \mathrm{O}$ in hexanes as flash silica gel chromatography eluent condition to afford the titled compound as a colorless oil (501 mg, 89\%). ${ }^{1} \mathbf{H}$ NMR (500 $\mathbf{~ M H z , ~} \mathbf{C D C l}_{3}$, mixture of rotamers) $\delta$ 7.45-7.41 (m, 2H), 7.33-7.26 (m, 3H), $4.10(\mathrm{~m}, 1 \mathrm{H}), 4.05-4.00(\mathrm{~m}, 2 \mathrm{H}), 3.95$ (d, $J=9.3 \mathrm{~Hz}$, 1H), 3.12 (br, 1H), 2.42-2.27 (m, 2H). ${ }^{13} \mathbf{C ~ N M R ~ ( 1 2 6 ~} \mathbf{~ M H z , ~ C D C l} 3$, mixture of rotamers) $\delta$ $131.72,128.67,128.39,122.25,88.78,84.95,80.02,73.38,67.76,42.47$. IR (neat): 3359,2951 , 2872, 1488, 1355, 1236, 1090, 1037, 940, 754, $689 \mathrm{~cm}^{-1}$. HRMS (ESI): exact mass calculated for $[\mathrm{M}+\mathrm{H}]^{+}\left(\mathrm{C}_{12} \mathrm{H}_{13} \mathrm{O}_{2}\right)$ requires $\mathrm{m} / \mathrm{z}$ 189.09101, found $\mathrm{m} / \mathrm{z} 189.09094$.

\section{3-(phenylethynyl)tetrahydro-2 $\mathrm{H}$-pyran-3-ol}

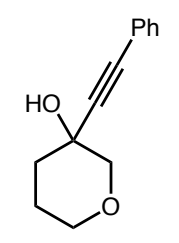

Prepared following the general procedure with phenylacetylene and dihydro- $2 H$-pyran-3(4H)-one using 3\% to $23 \% \mathrm{Et}_{2} \mathrm{O}$ in hexanes as flash silica gel chromatography eluent condition to afford the titled compound as a colorless oil (970 mg, 48\%). ${ }^{1} \mathbf{H}$ NMR (500 MHz, CDCl $\left.\mathbf{3}\right) \delta 7.45-7.43(\mathrm{~m}$, 2H), 7.33-7.28 (m, 3H), 3.80-3.70 (m, 3H), $3.61(\mathrm{~m}, 1 \mathrm{H}), 2.55$ (br, 1H), 2.05-2.03 (m, 2H), 1.91 $(\mathrm{m}, 1 \mathrm{H}), 1.70(\mathrm{~m}, 1 \mathrm{H}) .{ }^{13} \mathbf{C}$ NMR (126 MHz, $\left.\mathbf{C D C l}_{3}\right) \delta 131.95,128.67,128.39,122.39,90.06$, 85.07, 75.78, 68.07, 65.75, 36.56, 22.28. IR (neat): 3372, 2949, 2848, 1489, 1301, 1195, 1084, 922, 754, $690 \mathrm{~cm}^{-1}$. HRMS (ESI): exact mass calculated for $[\mathrm{M}+\mathrm{H}]^{+}\left(\mathrm{C}_{13} \mathrm{H}_{15} \mathrm{O}_{2}\right)$ requires $\mathrm{m} / \mathrm{z}$ 203.10666, found $\mathrm{m} / \mathrm{z} 203.10666$.

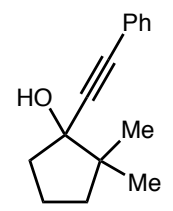

2,2-dimethyl-1-(phenylethynyl)cyclopentan-1-ol 
The titled compound was prepared according to a literature procedure. Spectra are consistent with reported literature values. ${ }^{19}$<smiles>C[C@H]1CCCC[C@@]1(O)C#CP</smiles>

\section{$\left(1 R^{*}, 2 S *\right)-2-m e t h y l-1-(p h e n y l e t h y n y l) c y c l o h e x a n-1-o l$}

The titled compound was prepared according to a literature procedure. Spectra are consistent with reported literature values. ${ }^{20}$

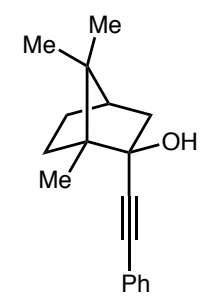

\section{(1R,2S,4R)-1,7,7-trimethyl-2-(phenylethynyl)bicyclo[2.2.1]heptan-2-ol}

The titled compound was prepared according to a literature procedure. Spectra are consistent with reported literature values. ${ }^{21}$

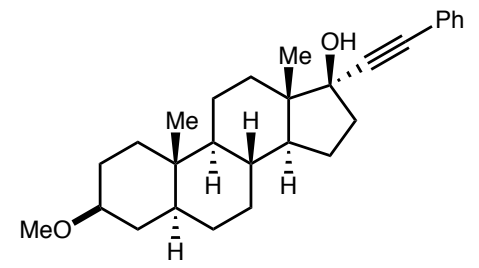

\section{(3S,5S,8R,9S,10S,13S,14S,17S)-3-methoxy-10,13-dimethyl-17-} (phenylethynyl)hexadecahydro- $1 H$-cyclopenta $[a]$ phenanthren-17-ol

The titled compound was synthesized via methylation of trans-androsterone, ${ }^{22}$ followed by alkynylation.

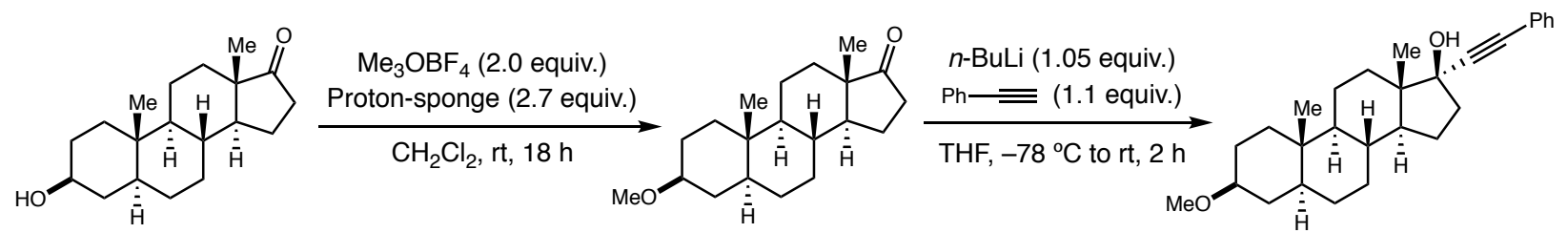

To a stirred solution of trans-androsterone (4.00 mmol, 1.00 eq., $1.16 \mathrm{~g})$ and Proton-sponge ${ }^{\circledR}(10.8$ mmol, 2.70 eq., $2.32 \mathrm{~g})$ in $\mathrm{CH}_{2} \mathrm{Cl}_{2}(160 \mathrm{~mL})$ was added trimethyloxonium tetrafluoroborate (8.00 mmol, 2.00 eq., $1.18 \mathrm{~g})$ at room temperature. The mixture was stirred at same temperature for 18 h. The reaction was quenched by addition of sat. aq. $\mathrm{NH}_{4} \mathrm{Cl}(20 \mathrm{~mL})$, extracted in $\mathrm{CH}_{2} \mathrm{Cl}_{2}(20 \mathrm{~mL}$, three times). The combined organic layers were washed with sat. aq. $\mathrm{NaCl}(20 \mathrm{~mL})$, dried over anhydrous $\mathrm{MgSO}_{4}$, filtered, and concentrated to a small volume. This crude was purified by silica gel flash column chromatography to furnish methylated trans-androsterone $(760 \mathrm{mg}, 62 \%)$ as a white solid. 
Data for $\quad(3 S, 5 S, 8 R, 9 S, 10 S, 13 S, 14 S)$-3-methoxy-10,13-dimethylhexadecahydro-17Hcyclopenta[a]phenanthren-17-one: ${ }^{1} \mathbf{H}$ NMR $\left(\mathbf{5 0 0} \mathbf{~ M H z}, \mathbf{C D C l}_{3}\right) \delta 3.33(\mathrm{~s}, 3 \mathrm{H}), 3.12(\mathrm{~m}, 1 \mathrm{H})$, $2.42(\mathrm{dd}, J=19.3,8.8 \mathrm{~Hz}, 1 \mathrm{H}), 2.05(\mathrm{~m}, 1 \mathrm{H}), 1.93-1.85(\mathrm{~m}, 2 \mathrm{H}), 1.80-1.76(\mathrm{~m}, 2 \mathrm{H}), 1.72(\mathrm{dt}, J=$ $13.2,3.7 \mathrm{~Hz}, 1 \mathrm{H}), 1.68-1.62(\mathrm{~m}, 2 \mathrm{H}), 1.57-1.44(\mathrm{~m}, 2 \mathrm{H}), 1.37-1.17(\mathrm{~m}, 7 \mathrm{H}), 1.08(\mathrm{~m}, 1 \mathrm{H}), 1.00$ $0.91(\mathrm{~m}, 2 \mathrm{H}), 0.85(\mathrm{~s}, 3 \mathrm{H}), 0.81(\mathrm{~s}, 3 \mathrm{H}), 0.68(\mathrm{~m}, 1 \mathrm{H}) .{ }^{13} \mathbf{C}$ NMR (126 MHz, CDCl $) \delta 221.54$, 79.82, 55.70, 54.62, 51.57, 47.93, 44.90, 37.00, 36.08, 35.98, 35.17, 34.42, 31.69, 31.06, 28.66, 27.91, 21.90, 20.61, 13.94, 12.37. IR (neat): 2918, 2855, 1743, 1447, 1375, 1240, 1096, 1012, 932, $830 \mathrm{~cm}^{-1}$. HRMS (ESI): exact mass calculated for $[\mathrm{M}+\mathrm{H}]^{+}\left(\mathrm{C}_{20} \mathrm{H}_{33} \mathrm{O}_{2}\right)$ requires $\mathrm{m} / \mathrm{z}$ 305.24751, found $m / z 305.24747$.

Following the general procedure, the alkynylation of methylated trans-androsterone with phenylacetylene afforded the titled compound as a white solid $(803.8 \mathrm{mg}, 82 \%)$. ${ }^{1} \mathbf{H}$ NMR (500 MHz, CDCl $\left.\mathbf{C}_{3}\right) \delta$ 7.46-7.42 (m, 2H), 7.34-7.29 (m, 3H), $3.34(\mathrm{~s}, 3 \mathrm{H}), 3.12(\mathrm{~m}, 1 \mathrm{H}), 2.35(\mathrm{~m}, 1 \mathrm{H})$, 2.08-1.96 (m, 2H), 1.77-1.17 (m, 16H), $1.07(\mathrm{~m}, 1 \mathrm{H}), 0.99-0.86(\mathrm{~m}, 2 \mathrm{H}), 0.88(\mathrm{~s}, 3 \mathrm{H}), 0.82(\mathrm{~s}$, $3 \mathrm{H}), 0.68(\mathrm{~m}, 1 \mathrm{H}) .{ }^{13} \mathbf{C}$ NMR (126 MHz, $\left.\mathbf{C D C l}_{3}\right) \delta 131.80,128.40,128.32,123.18,93.07,85.88$, $80.49,79.96,55.68,54.21,50.87,47.55,44.90,39.19,37.06,36.33,36.02,34.46,33.17,31.78$, 28.86, 28.00, 23.39, 21.08, 13.16, 12.44. IR (neat): 3401, 2922, 2852, 1443, 1379, 1292, 1093, 1041, 911, 755, $690 \mathrm{~cm}^{-1}$. HRMS (ESI): exact mass calculated for $[\mathrm{M}+\mathrm{H}]^{+}\left(\mathrm{C}_{28} \mathrm{H}_{39} \mathrm{O}_{2}\right)$ requires $\mathrm{m} / \mathrm{z}$ 407.29446, found $\mathrm{m} / \mathrm{z} 407.29419$. 


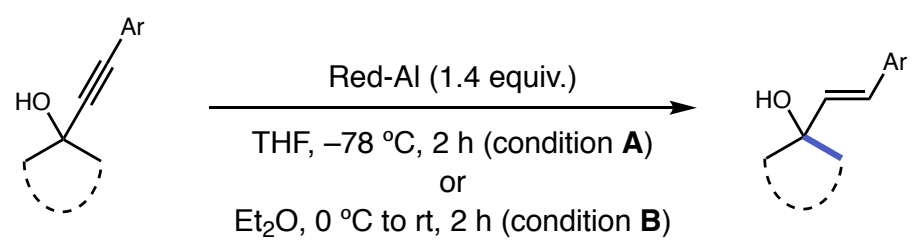

\section{General procedure for the reduction of $\alpha$-alkynyl alcohol: \\ Condition $\mathbf{A}^{23}$}

To an oven-dried round-bottomed flask, charged with a stir bar, was added $\alpha$-alkynyl alcohol (1.00 eq.) and THF. The solution was cooled to $-78{ }^{\circ} \mathrm{C}$ and was added Red-Al ${ }^{\circledR}$ sodium bis(2methoxyethoxy)aluminum hydride solution (1.40 eq.). The resulting mixture was stirred for another $2 \mathrm{~h}$ at same temperature. Afterwards, the reaction was quenched by slow addition of sat. aq. $\mathrm{NH}_{4} \mathrm{Cl}$ at $-78^{\circ} \mathrm{C}$. The resulting mixture extracted in $\mathrm{Et}_{2} \mathrm{O}(20 \mathrm{~mL}$, three times). The combined organic layers were washed with sat. aq. $\mathrm{NaCl}$, dried over anhydrous $\mathrm{MgSO}_{4}$, filtered, and concentrated to a small volume. This crude was purified by silica gel flash column chromatography ( $2 \%$ to $15 \%$ EtOAc in hexanes, unless otherwise noted) to obtain the allylic alcohol.

\section{$\underline{\text { Condition }}^{6}$}

To an oven-dried round-bottomed flask, charged with a stir bar, was added $\alpha$-alkynyl alcohol (1.00 eq.) and $\mathrm{Et}_{2} \mathrm{O}$. The solution was cooled to $0{ }^{\circ} \mathrm{C}$ and was added Red-Al ${ }^{\circledR}$ sodium bis(2methoxyethoxy)aluminum hydride solution (1.40 eq.). The resulting mixture was allowed to warm to room temperature and stirred for another $2 \mathrm{~h}$. Afterwards, the reaction was quenched by slow addition of sat. aq. $\mathrm{NH}_{4} \mathrm{Cl}(15 \mathrm{~mL})$ at $0{ }^{\circ} \mathrm{C}$. The resulting mixture was extracted in $\mathrm{Et}_{2} \mathrm{O}(20 \mathrm{~mL}$, three times). The combined organic layers were washed with brine. The combined organic layers were then dried over anhydrous $\mathrm{MgSO}_{4}$, filtered, and concentrated to a small volume. This crude was purified by silica gel flash column chromatography ( $2 \%$ to $15 \%$ EtOAc in hexanes, unless otherwise noted) to obtain the allylic alcohol.

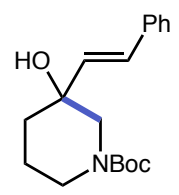

tert-butyl (E)-3-hydroxy-3-styrylpiperidine-1-carboxylate (17)

Prepared following the general procedure (condition B) with tert-butyl 3-hydroxy-3(phenylethynyl)piperidine-1-carboxylate to afford the titled compound as a white solid $(2.17 \mathrm{~g}$, 96\%). ${ }^{1} \mathbf{H}$ NMR (500 $\mathbf{~ M H z , ~} \mathbf{C D C l}_{3}$, mixture of rotamers) $\delta 7.38-7.37(\mathrm{~m}, 2 \mathrm{H}), 7.32-7.29(\mathrm{~m}$, 2H), $7.23(\mathrm{~m}, 1 \mathrm{H}), 6.75(\mathrm{~d}, J=16.1 \mathrm{~Hz}, 1 \mathrm{H}), 6.25(\mathrm{~d}, J=16.1 \mathrm{~Hz}, 1 \mathrm{H}), 3.80-3.64(\mathrm{~m}, 2 \mathrm{H}), 3.18-$ $3.03(\mathrm{~m}, 2 \mathrm{H}), 2.35(\mathrm{br}, 1 \mathrm{H}), 1.95-1.56(\mathrm{~m}, 4 \mathrm{H}), 1.47(\mathrm{~s}, 9 \mathrm{H}) .{ }^{13} \mathbf{C}$ NMR (126 $\mathbf{~ M H z}, \mathbf{C D C l}_{3}$, mixture of rotamers) $\delta 155.78,136.82,133.59,129.21,128.68,127.75,126.59,80.02,70.67$, 54.27, 53.42, 44.74, 43.51, 36.34, 28.54, 21.47. IR (neat): 3406, 2951, 2854, 1650, 1433, 1248, 1156, 961, 837, $746 \mathrm{~cm}^{-1}$. HRMS (ESI): exact mass calculated for $[\mathrm{M}+\mathrm{Na}]^{+}\left(\mathrm{C}_{18} \mathrm{H}_{25} \mathrm{NNaO}_{3}\right)$ requires $m / z$ 326.17266, found $m / z 326.17267$. 


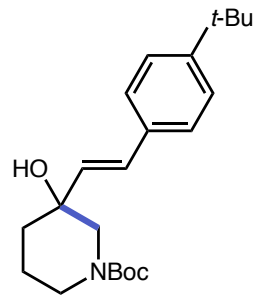

tert-butyl (E)-3-(4-(tert-butyl)styryl)-3-hydroxypiperidine-1-carboxylate (18)

Prepared following the general procedure (condition A) with tert-butyl 3-((4-(tertbutyl)phenyl)ethynyl)-3-hydroxypiperidine-1-carboxylate to afford the titled compound as a white solid (681 mg, 71\%). ${ }^{1} \mathbf{H}$ NMR (500 $\mathbf{~ M H z , ~} \mathbf{C D C l}_{3}$, mixture of rotamers) $\delta 7.34(\mathrm{~d}, J=8.6 \mathrm{~Hz}$, 2H), $7.32(\mathrm{~d}, J=8.6 \mathrm{~Hz}, 2 \mathrm{H}), 6.73(\mathrm{~d}, J=16.1 \mathrm{~Hz}, 1 \mathrm{H}), 6.22(\mathrm{~d}, J=16.1 \mathrm{~Hz}, 1 \mathrm{H}), 3.96-3.44(\mathrm{~m}$, 2H), 3.35-2.88 (m, 2H), 2.13 (br, 1H), 1.86-1.56 (m, 4H), 1.47 (s, 9H), 1.31 (s, 9H). ${ }^{13} \mathbf{C ~ N M R}$ $\left(126 \mathrm{MHz}, \mathrm{CDCl}_{3}\right.$, mixture of rotamers) $\delta 155.82,150.95,134.01,132.78,128.96,126.32$, $125.64,80.03,70.75,54.24,53.47,44.84,43.60,36.36,34.70,31.41,28.57,21.47$. IR (neat): 3455, 2961, 2864, 1669, 1424, 1267, 1151, 968, 902, $765 \mathrm{~cm}^{-1}$. HRMS (ESI): exact mass calculated for $[\mathrm{M}+\mathrm{Na}]^{+}\left(\mathrm{C}_{22} \mathrm{H}_{33} \mathrm{NNaO}_{3}\right)$ requires $m / z$ 382.23527, found $m / z$ 382.23508.

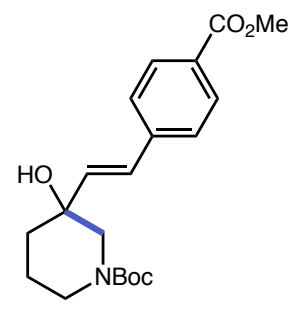

tert-butyl (E)-3-hydroxy-3-(4-(methoxycarbonyl)styryl)piperidine-1-carboxylate (19)

Prepared following the general procedure (condition A) with tert-butyl 3-hydroxy-3-((4(methoxycarbonyl)phenyl)ethynyl)piperidine-1-carboxylate using $4 \%$ to $27 \%$ EtOAc in hexanes as flash silica gel chromatography eluent condition to afford the titled compound as a white solid $(1.55 \mathrm{~g}, 93 \%)$. ${ }^{1} \mathrm{H}$ NMR (500 $\mathbf{~ M H z}, \mathbf{C D C l}_{3}$, mixture of rotamers) $\delta 7.97(\mathrm{~d}, J=8.0 \mathrm{~Hz}, 2 \mathrm{H})$, $7.42(\mathrm{~d}, J=8.0 \mathrm{~Hz}, 2 \mathrm{H}), 6.79(\mathrm{~d}, J=16.0 \mathrm{~Hz}, 1 \mathrm{H}), 6.36(\mathrm{~d}, J=16.0 \mathrm{~Hz}, 1 \mathrm{H}), 3.90(\mathrm{~s}, 3 \mathrm{H}), 3.82-$ $3.53(\mathrm{~m}, 2 \mathrm{H}), 3.17-2.84(\mathrm{~m}, 2 \mathrm{H}), 2.36(\mathrm{br}, 1 \mathrm{H}), 1.91-1.66(\mathrm{~m}, 4 \mathrm{H}), 1.46(\mathrm{~s}, 9 \mathrm{H}) .{ }^{13} \mathrm{C}$ NMR (126 $\mathbf{M H z}, \mathbf{C D C l}_{3}$, mixture of rotamers) $\delta 167.01,156.04,155.55,141.35,136.24,130.05,129.14$, $128.40,126.49,80.19,70.84,54.20,53.22,52.24,44.79,43.52,36.22,28.53,21.39$. IR (neat): 3418, 2932, 2857, 1718, 1665, 1428, 1273, 1151, 1107, 969, 869, $762 \mathrm{~cm}^{-1}$. HRMS (ESI): exact mass calculated for $[\mathrm{M}+\mathrm{H}]^{+}\left(\mathrm{C}_{20} \mathrm{H}_{28} \mathrm{NO}_{5}\right)$ requires $m / z$ 362.19620, found $\mathrm{m} / \mathrm{z} 362.19613$.

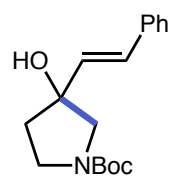

tert-butyl (E)-3-hydroxy-3-styrylpyrrolidine-1-carboxylate (20)

Prepared following the general procedure (condition A) with tert-butyl 3-hydroxy-3(phenylethynyl)pyrrolidine-1-carboxylate to afford the titled compound as a white solid (1.14 g, 65\%). ${ }^{1} \mathrm{H}$ NMR (500 MHz, $\mathbf{C D C l}_{3}$, mixture of rotamers) $\delta 7.40-7.38(\mathrm{~m}, 2 \mathrm{H}), 7.35-7.32(\mathrm{~m}$, 2H), $7.26(\mathrm{~m}, 1 \mathrm{H}), 6.77(\mathrm{dd}, J=16.1,4.3 \mathrm{~Hz}, 1 \mathrm{H}), 6.32(\mathrm{~d}, J=16.1 \mathrm{~Hz}, 1 \mathrm{H}), 3.66-3.41(\mathrm{~m}, 4 \mathrm{H})$, $2.44(\mathrm{~m}, 1 \mathrm{H}), 2.10-1.90(\mathrm{~m}, 2 \mathrm{H}), 1.47(\mathrm{~s}, 9 \mathrm{H}) .{ }^{13} \mathrm{C} \mathbf{~ N M R}\left(126 \mathbf{~ M H z}, \mathbf{C D C l}_{3}\right.$, mixture of rotamers) $\delta 154.84,154.74,136.40,131.49,129.56,129.47,128.75,127.94,126.64,126.60$, 
79.62, 79.51, 78.68, 58.41, 58.08, 45.00, 44.59, 39.08, 38.64, 28.63. IR (neat): 3389, 2975, 2898, 1660, 1415, 1255, 1124, 971, 877, $750 \mathrm{~cm}^{-1}$. HRMS (ESI): exact mass calculated for [M+H] ${ }^{+}$ $\left(\mathrm{C}_{17} \mathrm{H}_{24} \mathrm{NO}_{3}\right)$ requires $\mathrm{m} / z$ 290.17507, found $\mathrm{m} / \mathrm{z} 290.17500$.

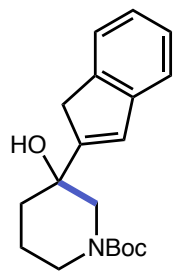

tert-butyl 3-hydroxy-3-(1H-inden-2-yl)piperidine-1-carboxylate (21)

The titled compound was synthesized via Grignard addition of tert-butyl 3-oxopiperidine-1carboxylate following a literature procedure. ${ }^{7}$

A flame-dried 250-mL three-necked round-bottomed flask was charged with a stir bar and magnesium turnings $(24.0 \mathrm{mmol}, 1.30$ eq., $583 \mathrm{mg})$. The flask was then evacuated and refilled with argon. THF (40 mL) was added to the flask, and a THF $(5 \mathrm{~mL})$ solution of 2-bromoindene ( $20.0 \mathrm{mmol}, 1.10$ eq., $3.90 \mathrm{~g}$ ) was added dropwise. The mixture was stirred at room temperature under argon atmosphere for $30 \mathrm{~min}$ and was then refluxed for another $1 \mathrm{~h}$ to complete the formation of the Grignard reagent. Afterwards, the solution was cooled to $0{ }^{\circ} \mathrm{C}$ in an ice bath, and a THF (5 $\mathrm{mL})$ solution of ketone (18.0 mmol, 1.00 eq., $3.59 \mathrm{~g})$ was added dropwise. The reaction was allowed to warm to room temperature and stirred for another $12 \mathrm{~h}$. The reaction was quenched by addition of sat. aq. $\mathrm{NH}_{4} \mathrm{Cl}(30 \mathrm{~mL})$, extracted in $\mathrm{Et}_{2} \mathrm{O}(30 \mathrm{~mL}$, three times). The combined organic layers were washed with sat. aq. $\mathrm{NaCl}(30 \mathrm{~mL})$, dried over anhydrous $\mathrm{MgSO}_{4}$, filtered, and concentrated to a small volume. This crude was purified by silica gel flash column chromatography ( $2 \%$ to $15 \%$ EtOAc in hexanes, four times) to obtain the titled compound $(2.34 \mathrm{~g}, 34 \%$ yield) as an orange solid. ${ }^{1} \mathbf{H}$ NMR (500 $\mathbf{~ M H z , ~} \mathbf{C D C l}_{3}$, mixture of rotamers) $\delta 7.43(\mathrm{~d}, J=7.4 \mathrm{~Hz}, 1 \mathrm{H})$, $7.34(\mathrm{~d}, J=7.5 \mathrm{~Hz}, 1 \mathrm{H}), 7.26(\mathrm{t}, J=7.3 \mathrm{~Hz}, 1 \mathrm{H}), 7.17(\mathrm{td}, J=7.4,1.2 \mathrm{~Hz}, 1 \mathrm{H}), 6.82(\mathrm{~s}, 1 \mathrm{H}), 4.00$ $3.67(\mathrm{~m}, 2 \mathrm{H}), 3.50(\mathrm{~d}, J=5.7 \mathrm{~Hz}, 2 \mathrm{H}), 3.30$ (br, 1H), 3.02 (br, 1H), 2.34 (br, 1H), 1.98-1.78 (m, 4H), 1.47 (s, 9H). ${ }^{13} \mathbf{C}$ NMR (126 MHz, $\mathbf{C D C l}_{3}$, mixture of rotamers) $\delta 156.09,152.72,144.51$, $143.10,127.03,126.57,124.78,123.84,121.10,80.15,70.53,54.33,53.54,44.94,43.68,37.87$, 36.17, 28.54, 21.46. IR (neat): 3418, 2928, 2857, 1663, 1425, 1243, 1147, 862, $751 \mathrm{~cm}^{-1}$. HRMS (ESI): exact mass calculated for $[\mathrm{M}+\mathrm{Na}]^{+}\left(\mathrm{C}_{19} \mathrm{H}_{25} \mathrm{NNaO}_{3}\right)$ requires $\mathrm{m} / \mathrm{z} 338.17266$, found $\mathrm{m} / \mathrm{z}$ 338.17233 .

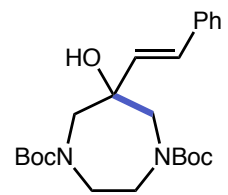

di-tert-butyl (E)-6-hydroxy-6-styryl-1,4-diazepane-1,4-dicarboxylate (22)

Prepared following the general procedure (condition B) with di-tert-butyl 6-hydroxy-6(phenylethynyl)-1,4-diazepane-1,4-dicarboxylateto to afford the titled compound as a white solid (662 mg, 97\%). ${ }^{1} \mathbf{H}$ NMR (400 MHz, DMSO-d 6 , $\left.120^{\circ} \mathrm{C}\right) \delta 7.37$ - 7.35 (m, 2H), 7.32 - 7.29 (m, 2H), $7.21(\mathrm{~m}, 1 \mathrm{H}), 6.74(\mathrm{~d}, J=16.1 \mathrm{~Hz}, 1 \mathrm{H}), 6.33(\mathrm{~d}, J=16.1 \mathrm{~Hz}, 1 \mathrm{H}), 4.53(\mathrm{~s}, 1 \mathrm{H}), 3.71(\mathrm{~d}, J=$ $14.2 \mathrm{~Hz}, 2 \mathrm{H}), 3.68-3.59$ (m, 2H), 3.46-3.38 (m, 2H), 3.33 (d, J=14.2 Hz, 2H), 1.39 (s, $18 \mathrm{H}) .{ }^{13} \mathrm{C}$ NMR (101 MHz, DMSO-d $\left.\mathbf{~}^{120}{ }^{\circ} \mathbf{C}\right) \delta 154.27,136.83,133.10,127.66,126.72,126.37,125.51$, 78.46, 73.86, 55.05, 45.99, 27.42. IR (neat): 3419, 2975, 2930, 1688, 1408, 1364, 1245, 1139, 
946, 862, $746 \mathrm{~cm}^{-1}$. HRMS (ESI): exact mass calculated for $[\mathrm{M}+\mathrm{Na}]^{+}\left(\mathrm{C}_{23} \mathrm{H}_{34} \mathrm{~N}_{2} \mathrm{NaO}_{5}\right)$ requires $\mathrm{m} / \mathrm{z} 441.23599$, found $\mathrm{m} / \mathrm{z} 441.23572$.

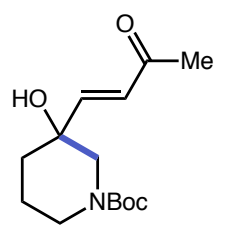

\section{(E)-tert-butyl 3-hydroxy-3-(3-oxobut-1-en-1-yl)piperidine-1-carboxylate (23)}

The titled compound was synthesized via cross metathesis of tert-butyl 3-hydroxy-3vinylpiperidine-1-carboxylate (1) with methyl vinyl ketone following a literature procedure. ${ }^{24}$

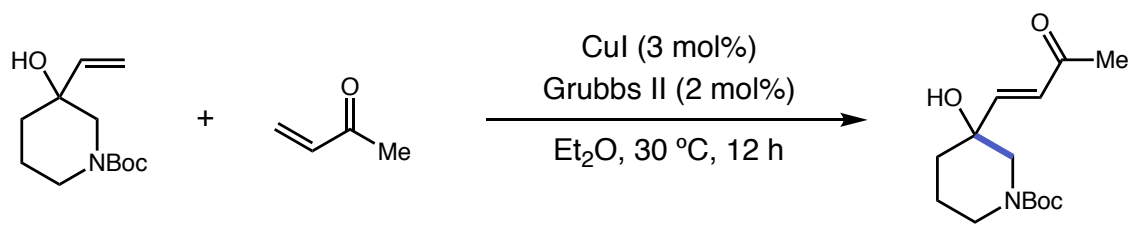

To an oven-dried 50-mL round-bottomed flask, charged with a stir bar and fitted with a condenser, is added tert-butyl 3-hydroxy-3-vinylpiperidine-1-carboxylate (1) (2.00 mmol, 1.00 eq., $455 \mathrm{mg})$ and Grubbs second generation catalyst $(0.06 \mathrm{mmol}, 0.03$ eq., $11.4 \mathrm{mg})$. The system was then brought into a glove box and was added copper(I) iodide $(0.04 \mathrm{mmol}, 0.02$ eq., $34.0 \mathrm{mg})$. The system was sealed and was brought out of glove box. Under $\mathrm{N}_{2}$ atmosphere, $\mathrm{Et}_{2} \mathrm{O}(20 \mathrm{~mL})$ was added in one portion. The mixture was stirred for $\sim 5 \mathrm{~min}$ and was then added methyl vinyl ketone $(8.00 \mathrm{mmol}, 4.00$ eq., $670 \mu \mathrm{L})$ in one portion. The resulting mixture was stirred at $30{ }^{\circ} \mathrm{C}$ for $12 \mathrm{~h}$. Afterwards, the reaction mixture was concentrated to a small volume and was then purified by silica gel flash column chromatography (5\% to 50\% EtOAc in hexanes) to furnish the titled compound (390.0 mg, 72\%) as a brown oil. ${ }^{1} \mathbf{H}$ NMR (500 $\mathbf{~ M H z , ~} \mathbf{C D C l}_{3}$, mixture of rotamers) $\delta 6.76(\mathrm{~d}, J=15.9 \mathrm{~Hz}, 1 \mathrm{H}), 6.43(\mathrm{~d}, J=15.9,1 \mathrm{H}), 4.00-3.48(\mathrm{~m}, 2 \mathrm{H}), 3.23-2.84(\mathrm{~m}, 2 \mathrm{H}), 2.42-$ $2.06(\mathrm{~m}, 4 \mathrm{H}), 1.88-1.52(\mathrm{~m}, 4 \mathrm{H}), 1.46(\mathrm{~s}, 9 \mathrm{H}) .{ }^{13} \mathbf{C}$ NMR (126 $\mathbf{M H z}, \mathbf{C D C l}_{3}$, mixture of rotamers) $\delta 198.47,155.53$ (br), 149.19, 129.00, 80.48, 70.78, 53.02, 52.64, 44.86, 43.08, 35.55, 28.52, 28.11, 21.03. IR (neat): 3418, 2975, 2932, 2861, 1667, 1423, 1364, 1251, 1209, 1151, 902, $765 \mathrm{~cm}^{-1}$. HRMS (EI): exact mass calculated for $[\mathrm{M}-\mathrm{Boc}+\mathrm{H}]^{+}\left(\mathrm{C}_{9} \mathrm{H}_{15} \mathrm{NO}_{2}\right)$ requires $\mathrm{m} / z$ 169.10973, found $\mathrm{m} / \mathrm{z} 169.10974$.

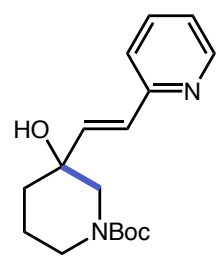

tert-butyl (E)-3-hydroxy-3-(2-(pyridin-2-yl)vinyl)piperidine-1-carboxylate (24)

Prepared following the general procedure (condition B but instead used THF as a solvent) with tert-butyl 3-hydroxy-3-(pyridin-2-ylethynyl)piperidine-1-carboxylate using 7\% to 60\% EtOAc in hexanes as flash silica gel chromatography eluent condition to afford the titled compound as a viscous, a colorless oil (447 mg, 58\%). ${ }^{1} \mathrm{H}$ NMR (500 $\mathbf{~ M H z , ~} \mathbf{C D C l}_{3}$, mixture of rotamers) $\delta 8.55$ $(\mathrm{d}, J=4.7 \mathrm{~Hz}, 1 \mathrm{H}), 7.63(\mathrm{td}, J=7.6,1.9 \mathrm{~Hz}, 1 \mathrm{H}), 7.24(\mathrm{~d}, J=7.7 \mathrm{~Hz}, 1 \mathrm{H}), 7.13$ (ddd, $J=7.6,4.7$, $1.3 \mathrm{~Hz}, 1 \mathrm{H}), 6.88-6.71(\mathrm{~m}, 2 \mathrm{H}), 4.00-3.58(\mathrm{~m}, 2 \mathrm{H}), 3.12(\mathrm{~s}, 1 \mathrm{H}), 2.92$ (ddd, $J=13.9,11.0,3.3 \mathrm{~Hz}$, 1H), 2.53-2.07 (m, 1H), 1.92-1.66 (m, 4H), 1.46 (s, 9H). ${ }^{13} \mathbf{C ~ N M R ~ ( 1 2 6 ~ M H z , ~ C D C l ~} 3$, mixture of rotamers) $\delta 155.84$ (br), 155.10, 149.67, 138.05, 136.81, 128.85, 122.56, 122.44, 80.12, 71.09, 
54.19, 53.13, 44.97, 43.46, 36.00, 28.54, 21.24. IR (neat) 3406, 2974, 2930, 2857, 1668, 1586, 1426, 1242, 1149, 974, 902, $763 \mathrm{~cm}^{-1}$. HRMS (ESI): exact mass calculated for $[\mathrm{M}+\mathrm{Na}]^{+}$ $\left(\mathrm{C}_{17} \mathrm{H}_{24} \mathrm{~N}_{2} \mathrm{NaO}_{3}\right)$ requires $\mathrm{m} / z$ 327.17691, found $\mathrm{m} / \mathrm{z} 327.16789$.

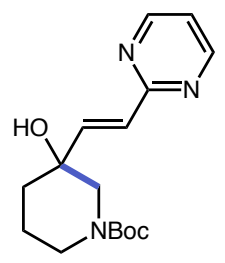

tert-butyl (E)-3-hydroxy-3-(2-(pyrimidin-2-yl)vinyl)piperidine-1-carboxylate (25)

Prepared following the general procedure (condition A) with tert-butyl 3-hydroxy-3-(pyrimidin2-ylethynyl)piperidine-1-carboxylate using $20 \%$ to $80 \%$ EtOAc in hexanes as flash silica gel chromatography eluent condition to afford the titled compound as a viscous, a colorless oil (550 mg, 75\%). ${ }^{1} \mathbf{H}$ NMR (500 MHz, $\mathbf{C D C l}_{3}$, mixture of rotamers) $\delta 8.69(\mathrm{~d}, J=4.9 \mathrm{~Hz}, 2 \mathrm{H}), 7.18$ $(\mathrm{d}, J=15.6 \mathrm{~Hz}, 1 \mathrm{H}), 7.11(\mathrm{t}, J=4.9 \mathrm{~Hz}, 1 \mathrm{H}), 6.92(\mathrm{~d}, J=15.6 \mathrm{~Hz}, 1 \mathrm{H}), 4.09-3.53(\mathrm{~m}, 2 \mathrm{H}), 3.32-$ $2.78(\mathrm{~m}, 2 \mathrm{H}), 2.54-1.99(\mathrm{~m}, 1 \mathrm{H}), 1.95-1.78(\mathrm{~m}, 2 \mathrm{H}), 1.76-1.66(\mathrm{~m}, 1 \mathrm{H}), 1.63-1.53(\mathrm{~m}, 1 \mathrm{H}), 1.46$ $(\mathrm{s}, 9 \mathrm{H}) .{ }^{13} \mathbf{C} \mathbf{N M R}\left(\mathbf{1 2 6} \mathbf{~ M H z}, \mathbf{C D C l}_{3}\right.$, mixture of rotamers) $\delta 164.44,157.15,156.15,144.22$, $128.72,118.99,80.09,70.85,53.55,53.07,44.80,43.50,35.88,28.51,21.17$. IR (neat) 3399 , 2973, 2930, 2857, 1666, 1554, 1414, 1150, 864, 767, 636, $550 \mathrm{~cm}^{-1}$. HRMS (ESI): exact mass calculated for $[\mathrm{M}+\mathrm{H}]^{+}\left(\mathrm{C}_{16} \mathrm{H}_{24} \mathrm{~N}_{3} \mathrm{O}_{3}\right)$ requires $m / z$ 306.18122, found $m / z$ 306.18123.

\section{(E)-3-styryltetrahydrofuran-3-ol (26)}

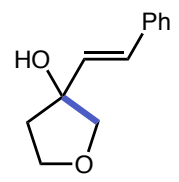

Prepared following the general procedure (condition B) with 3-(phenylethynyl)tetrahydrofuran-3ol using 3\% to $23 \% \mathrm{Et}_{2} \mathrm{O}$ in hexanes as flash silica gel chromatography eluent condition to afford the titled compound as a white solid (507 mg, 89\%). ${ }^{\mathbf{1}} \mathbf{H}$ NMR (500 $\left.\mathbf{~ M H z , ~ C D C l} 3\right) \delta 7.40-7.39$ $(\mathrm{m}, 2 \mathrm{H}) 7.34-7.31(\mathrm{~m}, 2 \mathrm{H}), 7.25(\mathrm{~m}, 1 \mathrm{H}), 6.80(\mathrm{~d}, J=16.0 \mathrm{~Hz}, 1 \mathrm{H}), 6.32(\mathrm{~d}, J=16.0 \mathrm{~Hz}, 1 \mathrm{H})$, $4.15(\mathrm{~m}, 1 \mathrm{H}), 4.04(\mathrm{td}, J=8.7,3.5 \mathrm{~Hz}, 1 \mathrm{H}), 3.79(\mathrm{~d}, J=9.5 \mathrm{~Hz}, 1 \mathrm{H}), 3.75(\mathrm{~d}, J=9.5 \mathrm{~Hz}, 1 \mathrm{H}), 2.20$ (m, 1H), 2.07 (m, 1H), 1.90 (br, 1H). ${ }^{13} \mathbf{C}$ NMR (126 MHz, CDCl $\mathbf{~}_{3} \delta 136.51,130.74,129.45$, 128.74, 127.84, 126.56, 80.90, 79.00, 67.94, 41.16. IR (neat): 3348, 2951, 2886, 1463, 1355, 1276, 1081, 1031, 971, 886, 753, $696 \mathrm{~cm}^{-1}$. HRMS (ESI): exact mass calculated for [M+H] ${ }^{+}$ $\left(\mathrm{C}_{12} \mathrm{H}_{15} \mathrm{O}_{2}\right)$ requires $m / z$ 191.10666, found $m / z$ 191.10663.

(E)-3-styryltetrahydro-2H-pyran-3-ol (27)

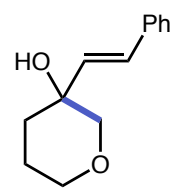

Prepared following the general procedure (condition A) with 3-(phenylethynyl)tetrahydro- $2 \mathrm{H}$ pyran-3-ol using 3\% to $23 \% \mathrm{Et}_{2} \mathrm{O}$ in hexanes as flash silica gel chromatography eluent condition to afford the titled compound as a white solid (916 mg, quant.). ${ }^{1} \mathbf{H}$ NMR (500 $\left.\mathbf{~ M H z , ~ C D C l} \mathbf{3}\right) \delta$ 7.40-7.39 (m, 2H), 7.33-7.30 (m, 2H), $7.24(\mathrm{~m}, 1 \mathrm{H}), 6.76(\mathrm{~d}, J=16.1 \mathrm{~Hz}, 1 \mathrm{H}), 6.21(\mathrm{~d}, J=16.1$ $\mathrm{Hz}, 1 \mathrm{H}), 3.92(\mathrm{~m}, 1 \mathrm{H}), 3.59$ (dd, $J=11.5,1.5 \mathrm{~Hz}, 1 \mathrm{H}), 3.50-3.45(\mathrm{~m}, 2 \mathrm{H}), 2.49$ (br, $1 \mathrm{H}), 1.97$ (m, 1H), 1.87-1.76 (m, 2H), 1.61 (m, 1H). ${ }^{13} \mathbf{C}$ NMR (126 MHz, CDCl $\mathbf{~ M}_{3} \delta 136.79,132.16,129.65$, $128.67,127.75,126.56,75.84,69.97,68.04,34.88,22.04$. IR (neat): 3326, 2934, 2840, 1448, 
1307, 1201, 1080, 978, 929, 752, $696 \mathrm{~cm}^{-1}$. HRMS (ESI): exact mass calculated for $[\mathrm{M}+\mathrm{H}]^{+}$ $\left(\mathrm{C}_{13} \mathrm{H}_{17} \mathrm{O}_{2}\right)$ requires $m / z 205.12231$, found $\mathrm{m} / \mathrm{z} 205.12234$.

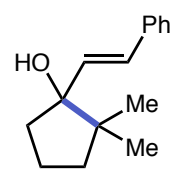

(E)-2,2-dimethyl-1-styrylcyclopentan-1-ol (28)

Prepared following the general procedure (condition B) with 2,2-dimethyl-1(phenylethynyl)cyclopentan-1-ol using $0 \%$ to $5 \% \mathrm{Et}_{2} \mathrm{O}$ in hexanes as flash silica gel chromatography eluent condition to afford the titled compound as a white solid (603 $\mathrm{mg}, 40 \%)$. ${ }^{1}$ H NMR (500 MHz, CDCl $\left.{ }_{3}\right) \delta 7.42-7.40(\mathrm{~m}, 2 \mathrm{H}), 7.34-7.31(\mathrm{~m}, 2 \mathrm{H}), 7.24(\mathrm{~m}, 1 \mathrm{H}), 6.67(\mathrm{~d}, J=$ $16.0 \mathrm{~Hz}, 1 \mathrm{H}), 6.39(\mathrm{~d}, J=16.0 \mathrm{~Hz}, 1 \mathrm{H}), 2.19(\mathrm{~m}, 1 \mathrm{H}), 1.94-1.73(\mathrm{~m}, 4 \mathrm{H}), 1.54(\mathrm{~m}, 1 \mathrm{H}), 1.42(\mathrm{~s}$, 1H), 1.01 (s, 3H), 0.94 (s, 3H). ${ }^{13} \mathbf{C}$ NMR (126 MHz, CDCl $\mathbf{~ M}_{3} \delta 137.34,132.97,128.79,128.68$, 127.40, 126.49, 84.88, 46.83, 38.93, 38.46, 25.83, 21.35, 19.84. IR (neat): 3570, 2956, 2857, 1601, 1448, 1273, 1139, 979, 832, 754, $697 \mathrm{~cm}^{-1}$. HRMS (ESI): exact mass calculated for [M+H] ${ }^{+}$ $\left(\mathrm{C}_{15} \mathrm{H}_{21} \mathrm{O}\right)$ requires $m / z 217.15869$, found $m / z 217.15848$.

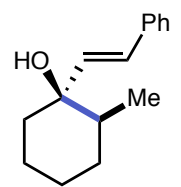

$\left(1 R^{*}, 2 S *\right)-2-m e t h y l-1-((E)-s t y r y l) c y c l o h e x a n-1-o l ~(29)$

Prepared following the general procedure (condition B) with $\left(1 R^{*}, 2 S^{*}\right)$-2-methyl-1(phenylethynyl)cyclohexan-1-ol using $0 \%$ to $3 \% \mathrm{Et}_{2} \mathrm{O}$ in hexanes as flash silica gel chromatography eluent condition to afford the titled compound as a white solid (559 $\mathrm{mg}, 82 \%)$. ${ }^{1}$ H NMR (500 MHz, CDCl $\left.{ }_{3}\right) \delta 7.43-7.41(\mathrm{~m}, 2 \mathrm{H}), 7.35-7.32(\mathrm{~m}, 2 \mathrm{H}), 7.24(\mathrm{~m}, 1 \mathrm{H}), 6.73(\mathrm{~d}, J=$ $16.1 \mathrm{~Hz}, 1 \mathrm{H}), 6.55(\mathrm{~d}, J=16.1 \mathrm{~Hz}, 1 \mathrm{H}), 1.91(\mathrm{~m}, 1 \mathrm{H}), 1.78-1.65(\mathrm{~m}, 5 \mathrm{H}), 1.62-1.49(\mathrm{~m}, 2 \mathrm{H}), 1.38$ $(\mathrm{m}, 1 \mathrm{H}), 1.28(\mathrm{~m}, 1 \mathrm{H}), 0.92(\mathrm{~d}, J=6.8 \mathrm{~Hz}, 3 \mathrm{H}) .{ }^{13} \mathbf{C}$ NMR (126 MHz, CDCl $) \delta 137.46,131.98$, 128.99, 128.65, 127.39, 126.48, 75.19, 42.40, 40.21, 31.71, 25.20, 23.78, 15.69. IR (neat): 3406, 2925, 2854, 1597, 1447, 1334, 1028, 968, 743, $691 \mathrm{~cm}^{-1}$. HRMS (ESI): exact mass calculated for $[\mathrm{M}+\mathrm{H}]^{+}\left(\mathrm{C}_{15} \mathrm{H}_{21} \mathrm{O}\right)$ requires $m / z 217.15869$, found $m / z 217.15855$.

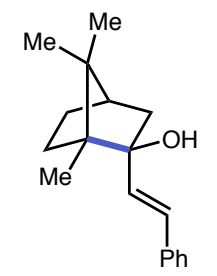

$(1 R, 2 S, 4 R)-1,7,7-t r i m e t h y l-2-((E)$-styryl)bicyclo[2.2.1]heptan-2-ol (30)

Prepared following the general procedure (condition B) with $(1 R, 2 S, 4 R)$-1,7,7-trimethyl-2(phenylethynyl)bicyclo[2.2.1] heptan-2-ol using $0 \%$ to $5 \% \mathrm{Et}_{2} \mathrm{O}$ in hexanes as flash silica gel chromatography eluent condition to afford the titled compound as a white solid $(1.22 \mathrm{~g}, 68 \%)$. ${ }^{1} \mathbf{H}$ NMR (500 MHz, CDCl $\left.{ }_{3}\right) \delta 7.41-7.40(\mathrm{~m}, 2 \mathrm{H}), 7.34-7.31(\mathrm{~m}, 2 \mathrm{H}), 7.23(\mathrm{~m}, 1 \mathrm{H}), 6.63(\mathrm{~d}, J=16.1$ $\mathrm{Hz}, 1 \mathrm{H}), 6.40(\mathrm{~d}, J=16.1 \mathrm{~Hz}, 1 \mathrm{H}), 2.12(\mathrm{dt}, J=13.4,3.8 \mathrm{~Hz}, 1 \mathrm{H}), 1.84-1.82(\mathrm{~m}, 2 \mathrm{H}), 1.74(\mathrm{~m}$, $1 \mathrm{H}), 1.53(\mathrm{~s}, 1 \mathrm{H}), 1.46-1.36(\mathrm{~m}, 2 \mathrm{H}), 1.18(\mathrm{~s}, 3 \mathrm{H}), 1.11(\mathrm{~m}, 1 \mathrm{H}), 0.90(\mathrm{~s}, 3 \mathrm{H}), 0.89(\mathrm{~s}, 3 \mathrm{H}) .{ }^{13} \mathrm{C}$ NMR (126 MHz, CDCl $) \delta$ ) 137.34, 136.24, 128.69, 127.77, 127.45, 126.56, 81.64, 53.55, 49.31, 
45.92, 45.74, 31.53, 27.09, 21.50, 21.11, 10.02. IR (neat): 3424, 2932, 2869, 1447, 1387, 1275 , 1069, 968, 744, $690 \mathrm{~cm}^{-1}$. HRMS (ESI): exact mass calculated for $[\mathrm{M}+\mathrm{H}]^{+}\left(\mathrm{C}_{18} \mathrm{H}_{25} \mathrm{O}\right)$ requires $\mathrm{m} / \mathrm{z} 257.18999$, found $\mathrm{m} / \mathrm{z} 257.18109$.

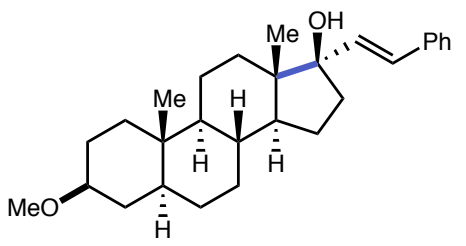

$(3 S, 5 S, 8 R, 9 S, 10 S, 13 S, 14 S, 17 R)$-3-methoxy-10,13-dimethyl-17-((E)-styryl)hexadecahydro$1 H$-cyclopenta[a]phenanthren-17-ol (31)

Prepared following the general procedure (condition A) with $(3 S, 5 S, 8 R, 9 S, 10 S, 13 S, 14 S, 17 S)$-3methoxy-10,13-dimethyl-17-(phenylethynyl)hexadecahydro-1 $H$-cyclopenta $[a]$ phenanthren-17-ol using $2 \%$ to $10 \% \mathrm{Et}_{2} \mathrm{O}$ in hexanes as flash silica gel chromatography eluent condition to afford the titled compound as a white solid (539 mg, 67\%). ${ }^{1} \mathbf{H}$ NMR (500 $\left.\mathbf{~ M H z}, \mathbf{C D C l}_{3}\right) \delta$ 7.42-7.41 (m, 2H), 7.34-7.31 (m, 2H), $7.24(\mathrm{~m}, 1 \mathrm{H}), 6.52(\mathrm{~d}, J=16.1 \mathrm{~Hz}, 1 \mathrm{H}), 6.43(\mathrm{~d}, J=16.1 \mathrm{~Hz}, 1 \mathrm{H}), 3.33$ $(\mathrm{s}, 3 \mathrm{H}), 3.10(\mathrm{~m}, 1 \mathrm{H}), 2.07(\mathrm{~m}, 1 \mathrm{H}), 1.93-1.85(\mathrm{~m}, 2 \mathrm{H}), 1.73-1.62(\mathrm{~m}, 4 \mathrm{H}), 1.60(\mathrm{~s}, 1 \mathrm{H}), 1.55-$ $1.16(\mathrm{~m}, 11 \mathrm{H}), 1.03(\mathrm{~m}, 1 \mathrm{H}), 0.94(\mathrm{~s}, 3 \mathrm{H}), 0.94-0.80(\mathrm{~m}, 2 \mathrm{H}), 0.80(\mathrm{~s}, 3 \mathrm{H}), 0.57(\mathrm{~m}, 1 \mathrm{H}) .{ }^{13} \mathrm{C}$ NMR (126 MHz, $\left.\mathbf{C D C l}_{3}\right) \delta 137.37,135.31,128.72,127.44,127.35,126.55,84.30,79.92,55.68$, $54.31,50.49,47.40,44.98,37.03,37.00,36.38,36.01,34.47,32.67,31.94,28.89,27.96,23.83$, 20.96, 14.43, 12.43. IR (neat): 3446, 2921, 2848, 1448, 1365, 1111, 970, 748, $690 \mathrm{~cm}^{-1}$. HRMS (ESI): exact mass calculated for $[\mathrm{M}+\mathrm{H}]^{+}\left(\mathrm{C}_{28} \mathrm{H}_{41} \mathrm{O}_{2}\right)$ requires $\mathrm{m} / \mathrm{z}$ 409.31011, found $\mathrm{m} / \mathrm{z}$ 409.31003. 


\section{Synthesis of Products}
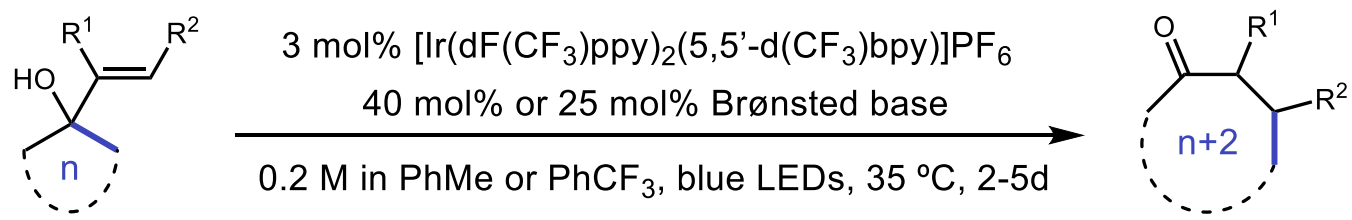

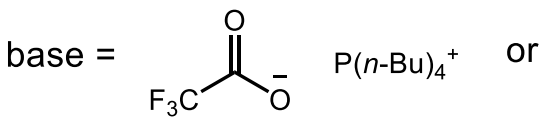

TFA<smiles>O=P([O-])(O)[PbH]</smiles>

dPh

\section{General Procedure A (n+2 Ring Expansion):}

An oven-dried 2-dram vial, charged with a magnetic stir bar, was added substrate $(0.500$ mmol, 1.00 equiv $)$ and $\left[\operatorname{Ir}\left(\mathrm{dF}\left(\mathrm{CF}_{3}\right) \text { ppy }\right)_{2}\left(5,5^{\prime}-\mathrm{d}\left(\mathrm{CF}_{3}\right) \mathrm{bpy}\right)\right] \mathrm{PF}_{6}(0.0150 \mathrm{mmol}, 3.00 \mathrm{~mol} \%, 17.2$ $\mathrm{mg}$ ), unless otherwise noticed. The vial was brought into a glove box where tetrabutylphosphonium 2,2,2-trifluoroacetate $(0.200 \mathrm{mmol}, 40.0 \mathrm{~mol} \%, 74.5 \mathrm{mg})$ or tetrabutylphosphonium diphenyl phosphate $(0.125 \mathrm{mmol}, 25.0 \mathrm{~mol} \%, 63.6 \mathrm{mg})$ was added. For when $\mathrm{PhCF}_{3}$ was used as the reaction solvent, $\mathrm{PhCF}_{3}(2.5 \mathrm{~mL})$ were added at this point. The vial was then sealed with a Teflon septa and electric tape and removed from the glovebox. For when PhMe was used as the reaction solvent, dry $\mathrm{PhMe}(2.5 \mathrm{~mL})$ was added by a syringe under $\mathrm{N}_{2}$ atmosphere. The reaction was stirred at $35^{\circ} \mathrm{C}$, which is the measured internal temperature using the reaction setup shown in Figure S1 and irradiated with two Kessil lamps (Kessil H150B LED Grow Light) for $2-5$ days. The reaction was then concentrated and purified by silica gel flash column chromatography. All preparative-scale reactions were run in duplicates, and the reported yield are the average yields of the two runs.

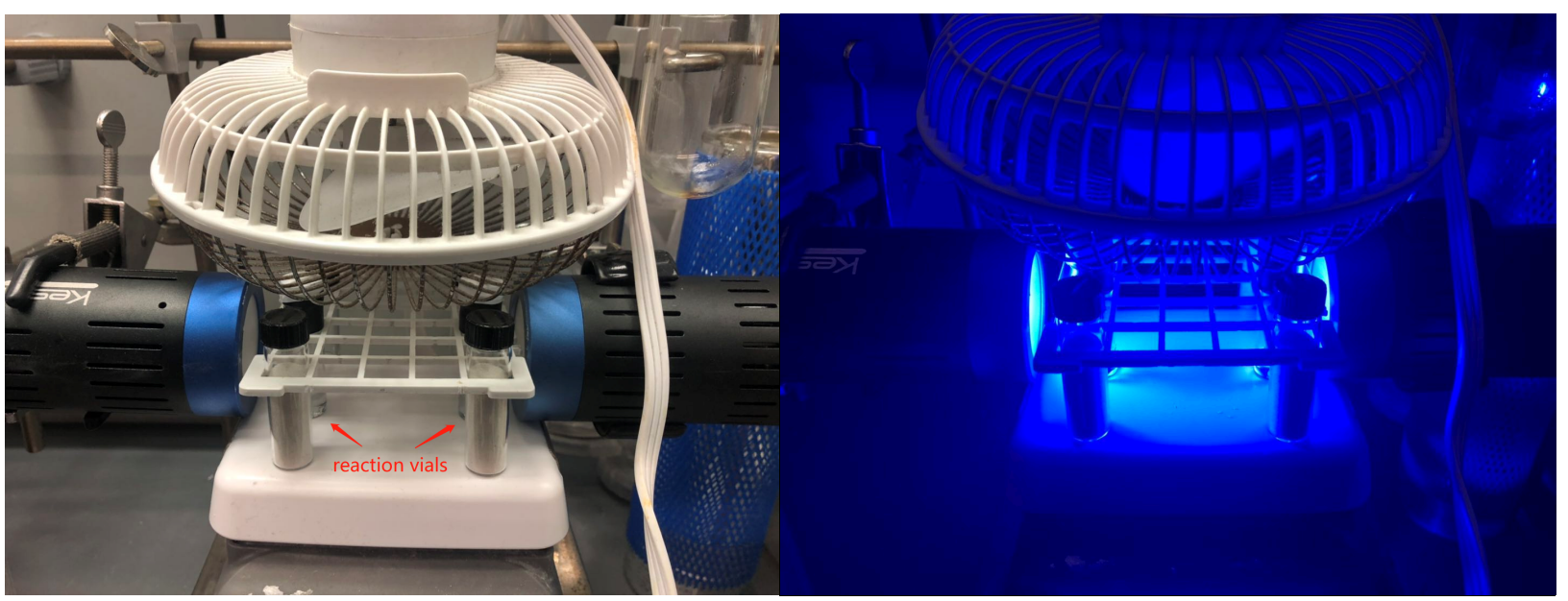

Figure S1. Lamps and fan setup examples. A test tube rack is used to hold the reaction vials. 


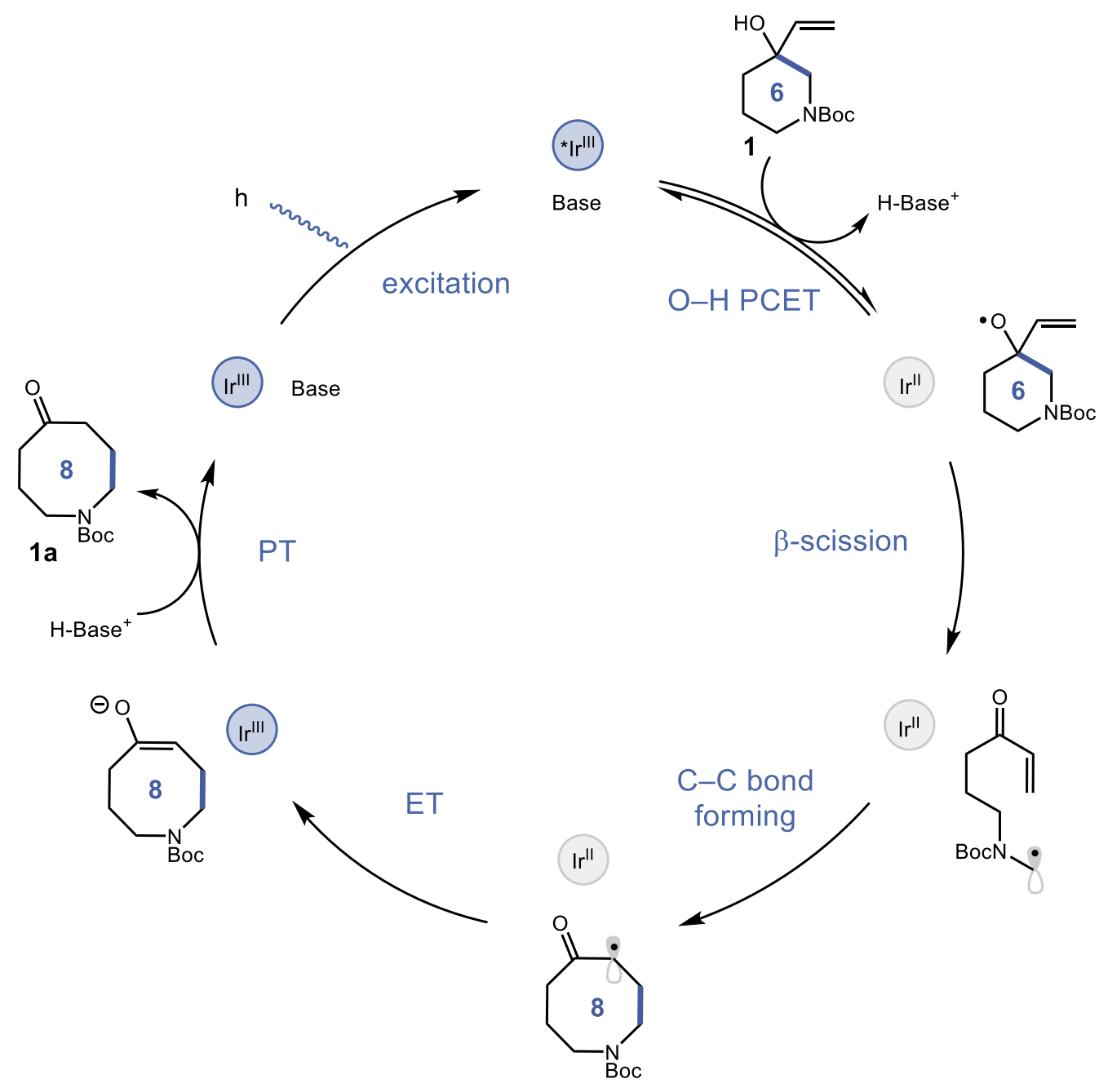

Figure S2. Proposed binary catalytic system for $\mathrm{n}+2$ ring expansion 


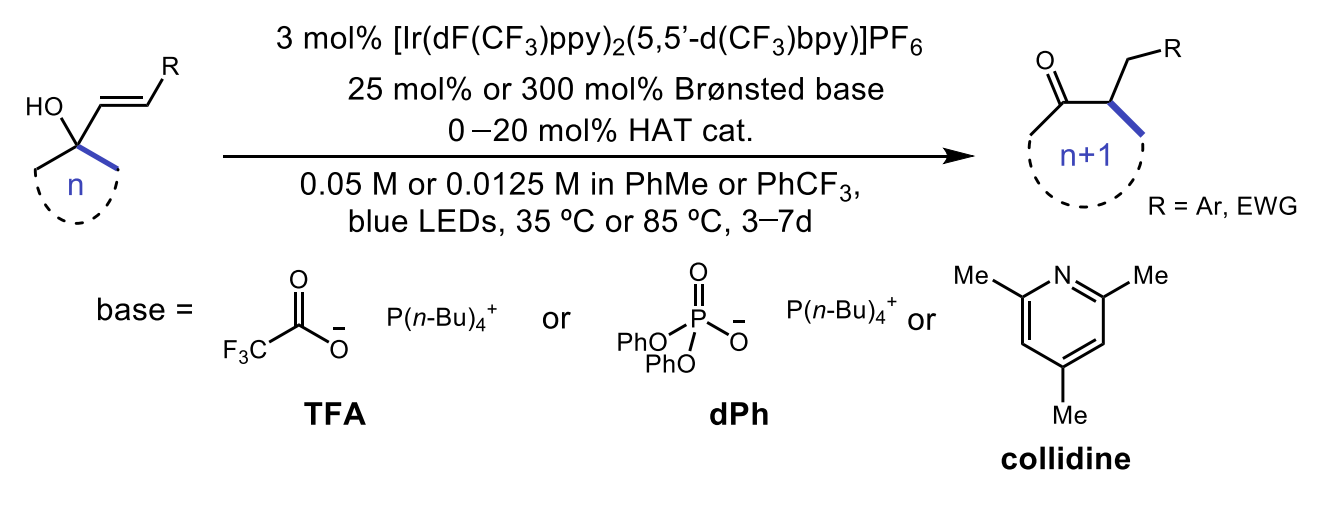

\section{General Procedure B (n+1 Ring Expansion and n+2 Ring Expansion):}

An oven-dried screw cap culture tube $(16 \times 125 \mathrm{~mm}$ or $28 \times 139 \mathrm{~mm})$ outfitted with a $\mathrm{PTFE} /$ silicone septum was charged with the relevant alcohol substrate $(0.500 \mathrm{mmol}, 1.00$ equiv. $)$ and $\left.\left[\operatorname{Ir}\left(\mathrm{dF}_{(\mathrm{CF}}\right) \mathrm{ppy}\right)_{2}\left(5,5^{\prime}-\mathrm{d}\left(\mathrm{CF}_{3}\right) \mathrm{bpy}\right)\right] \mathrm{PF}_{6}(0.0150 \mathrm{mmol}, 3.00 \mathrm{~mol} \%, 17.2 \mathrm{mg})$. The culture tube was brought into a glove box, where tetrabutylphosphonium 2,2,2-trifluoroacetate $(0.125 \mathrm{mmol}$, $25.0 \mathrm{~mol} \%, 46.6 \mathrm{mg})$ or tetrabutylphosphonium diphenyl phosphate $(0.125 \mathrm{mmol}, 25.0 \mathrm{~mol} \%$, $63.6 \mathrm{mg})$ was weighed in. In the case of collidine base $(1.50 \mathrm{mmol}, 3.00$ equiv., $198 \mu \mathrm{L})$, it was instead added via syringe after capping, outside the glovebox. For when $\mathrm{PhCF}_{3}$ was used as the reaction solvent, $\mathrm{PhCF}_{3}(10.0 \mathrm{~mL})$ were added in the glovebox. The culture tube was then sealed with PTFE and electric tape and removed from the glovebox. For when PhMe was used as the reaction solvent, dry PhMe (10.0 mL or $40.0 \mathrm{~mL})$ was added via a syringe under $\mathrm{N}_{2}$ atmosphere. Lastly, 2,4,6-triisopropylbenzenthiol (TRIP-SH) or benzenethiol ( $0 \mathrm{~mol} \%$ to $20 \mathrm{~mol} \%$ ) was added. The reaction was stirred at $35{ }^{\circ} \mathrm{C}$ (with a fan to cool the reaction setup) or $85{ }^{\circ} \mathrm{C}$ (without fan), which is the measured internal temperature using the reaction setup shown in Figure $\mathbf{S 3}$ and irradiated with four Kessil lamps (Kessil H150B LED Grow Light) for $3-7$ days. The reaction was then flushed through a plug of silica gel with acetone. The crude mixtures were concentrated and purified by flash column chromatography. All preparative-scale reactions were run in duplicates, and the reported yield are the average yields of the two runs.

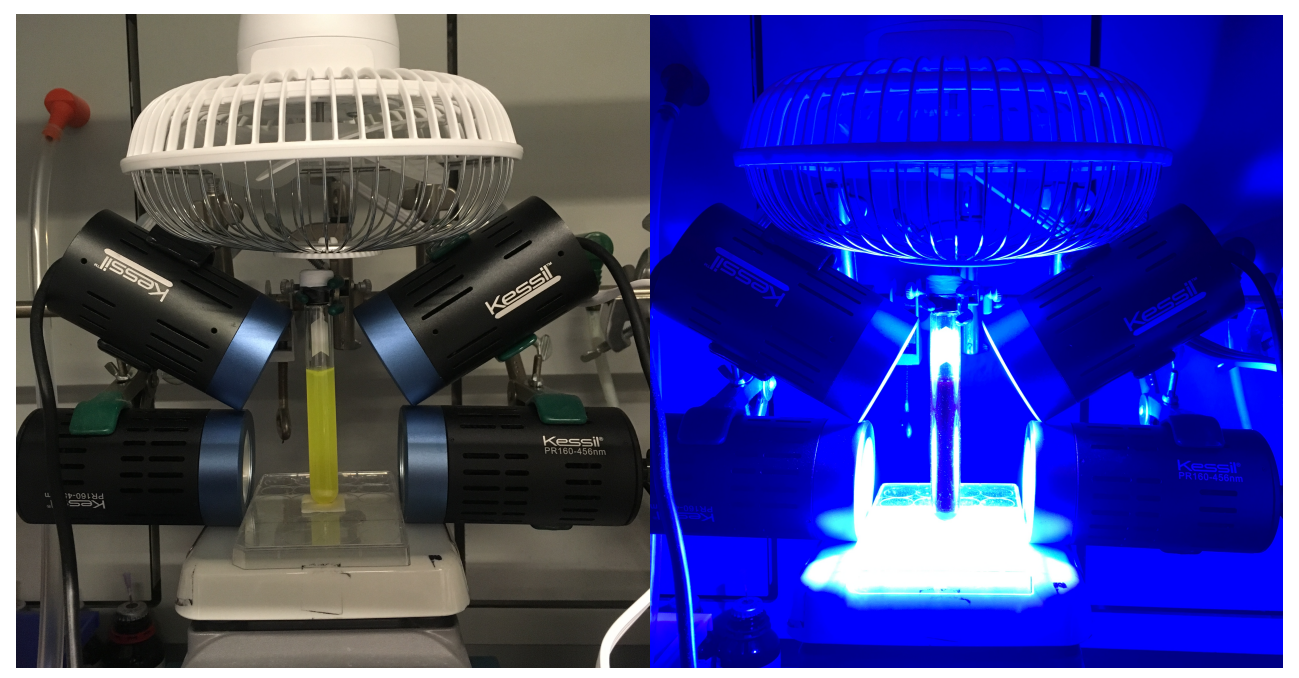

Figure S3. Lamps and fan setup examples. A clamp is used to hold the culture tube, and a riser can be used to align the bottom of the test tube with lights. This four-lamp configuration ensures even irradiation of the entire surface of the reaction vessel. 


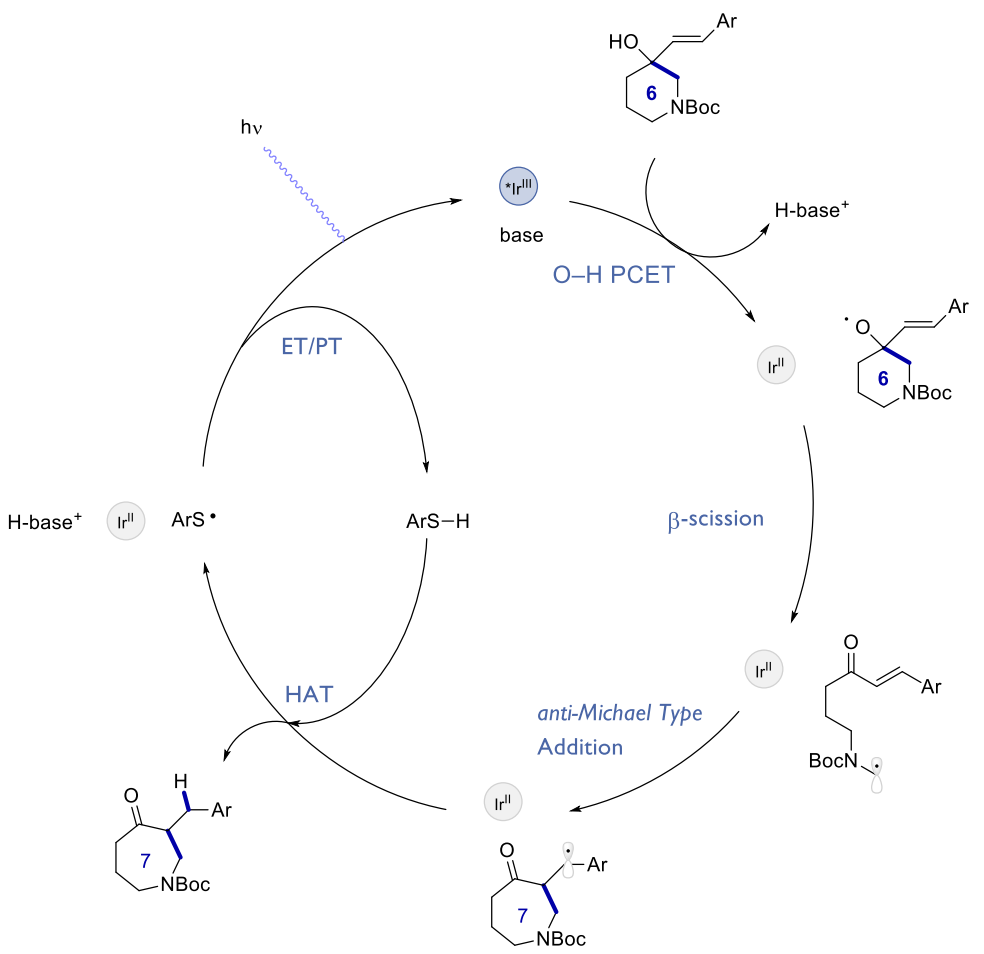

Figure S4. Proposed ternary catalytic system for $n+1$ ring expansion

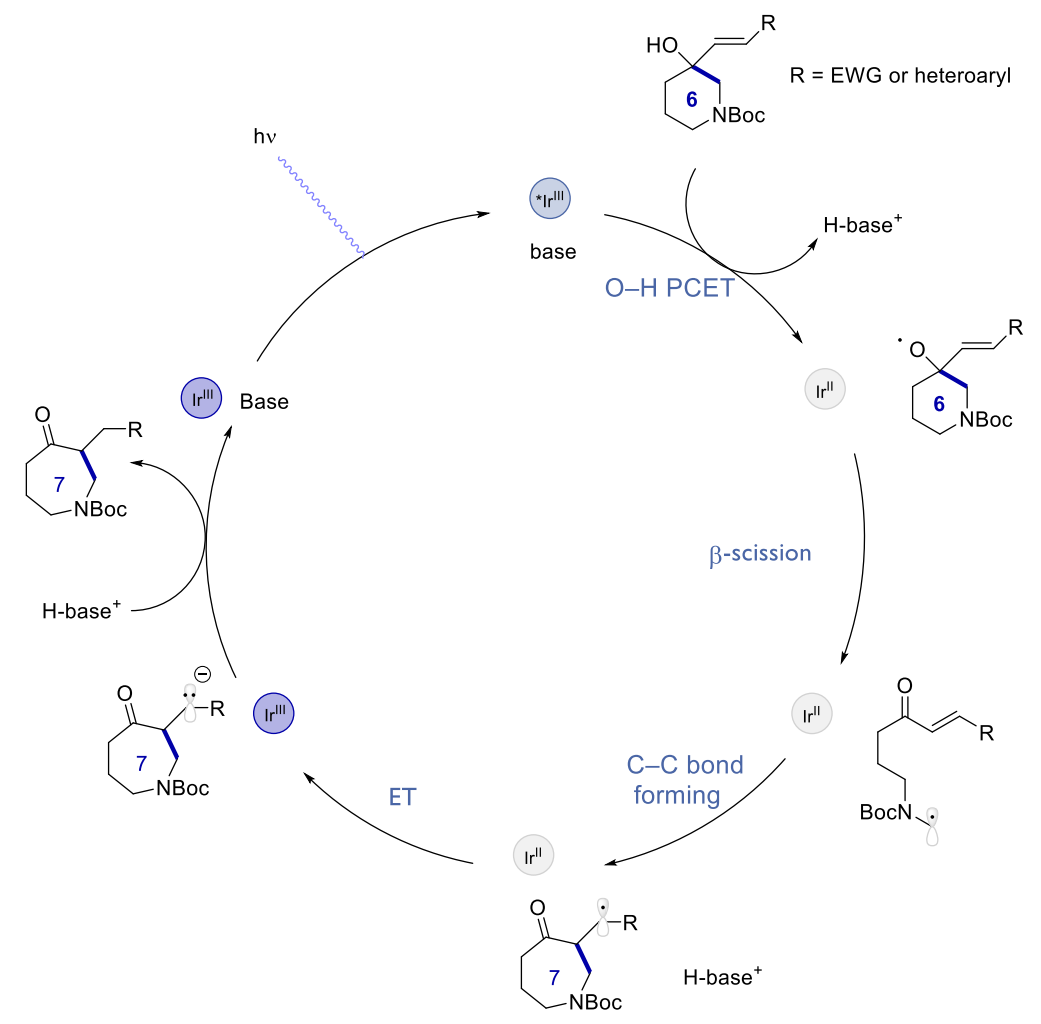

Figure S5. Proposed binary catalytic system for $n+1$ ring expansion (for 23a-25a) 
$\underline{\text { n+2 Ring Expansion }}$

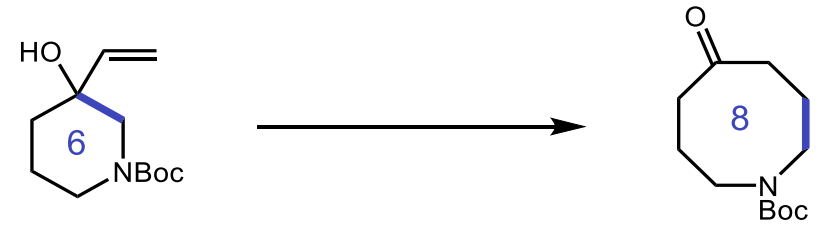

tert-butyl 5-oxoazocane-1-carboxylate (1a)

The titled compound was prepared on $0.5 \mathrm{mmol}$ scale following general procedure A with tertbutyl 3-hydroxy-3-vinylpiperidine-1-carboxylate (1) using PhMe solvent and TFA base and irradiated for $\underline{2 \mathrm{~d}}$. The crude material was purified by silica gel column chromatography (7\% to $60 \%$ EtOAc in hexanes) to afford the titled compound as a pale yellow solid (95.4 $\mathrm{mg}, 84 \%$ ). Spectra are consistent with reported literature values. ${ }^{25}$
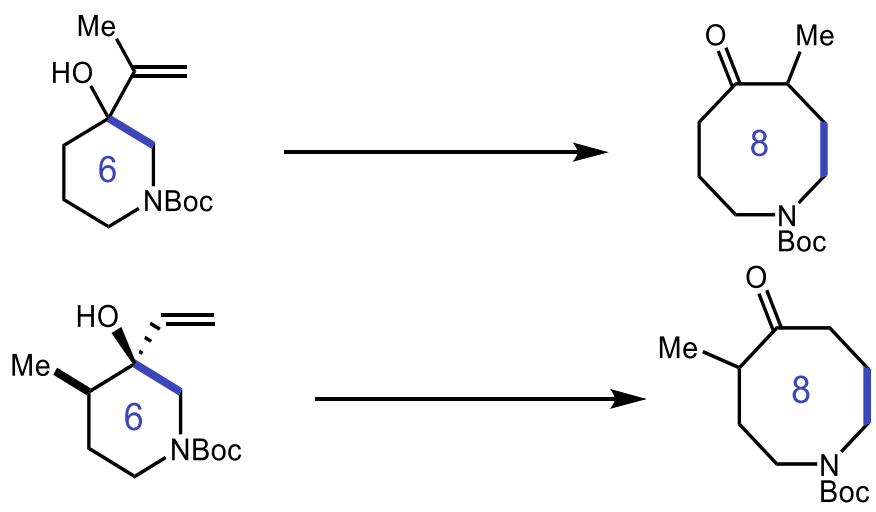

tert-butyl 4-methyl-5-oxoazocane-1-carboxylate (2a)

The titled compound was prepared on $0.5 \mathrm{mmol}$ scale following general procedure A with tertbutyl 3-hydroxy-3-(prop-1-en-2-yl)piperidine-1-carboxylate (2) using PhMe solvent and TFA base and irradiated for $3 \mathrm{~d}$. The crude material was purified by silica gel column chromatography $(7 \%$ to $60 \%$ EtOAc in hexanes) to afford the titled compound as a pale yellow solid $(98.6 \mathrm{mg}, 82 \%)$.

Alternatively, the titled compound was prepared on $0.5 \mathrm{mmol}$ scale following general procedure

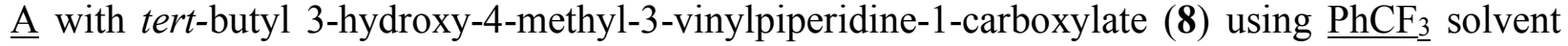
and TFA base and irradiated for $5 \mathrm{~d}$. The crude material was purified by silica gel column chromatography (7\% to $60 \%$ EtOAc in hexanes) to afford the titled compound as a pale yellow solid (74.8 mg, 62\%).

${ }^{1} \mathrm{H}$ NMR (500 MHz, $\mathbf{C D C l}_{3}$, mixture of rotamers) $\delta 3.59-2.97(\mathrm{~m}, 4 \mathrm{H}), 2.65-2.48(\mathrm{~m}, 1 \mathrm{H})$, 2.39-2.28 (m, 2H), 2.19-1.90 (m, 4H), 1.45 (s, 9H), 1.11-1.04 (m, 3H). ${ }^{13}$ C NMR (126 MHz, $\mathbf{C D C l}_{3}$, mixture of rotamers) $\delta 215.95,215.80,155.44,155.30,80.17,80.11,47.52,47.09,45.70$, 44.90, 43.67, 39.14, 37.64, 35.08, 33.42, 28.65, 28.39, 26.61, 16.01, 15.58. IR (neat): 2976, 2833, 1688, 1410, 1366, 1148, 776, $482 \mathrm{~cm}^{-1}$. HRMS (ESI): exact mass calculated for $[\mathrm{M}+\mathrm{Na}]^{+}$ $\left(\mathrm{C}_{13} \mathrm{H}_{23} \mathrm{NNaO}_{3}\right)$ requires $m / z 264.15701$, found $m / z 264.15689$. 

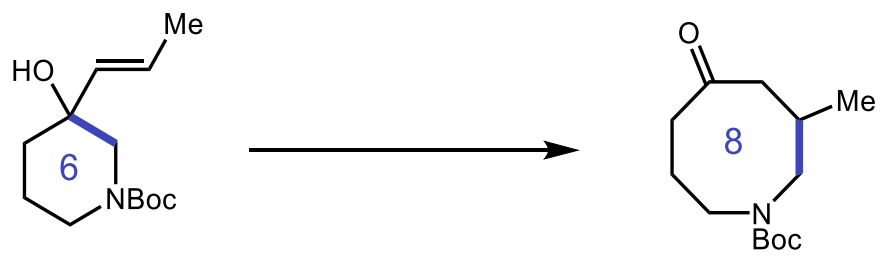

tert-butyl 3-methyl-5-oxoazocane-1-carboxylate (3a)

The titled compound was prepared on $0.5 \mathrm{mmol}$ scale following general procedure A with tertbutyl (E)-3-hydroxy-3-(prop-1-en-1-yl)piperidine-1-carboxylate (3) using PhMe solvent and TFA base and irradiated for $3 \mathrm{~d}$. The crude material was purified by silica gel column chromatography (7\% to $60 \%$ EtOAc in hexanes) to afford the titled compound as a pale yellow solid (95.0 $\mathrm{mg}$, 79\%). ${ }^{1} \mathbf{H}$ NMR (500 $\mathbf{~ M H z , ~} \mathbf{C D C l}_{3}$, mixture of rotamers) $\delta 3.86-2.52(\mathrm{~m}, 5 \mathrm{H}), 2.49-2.14(\mathrm{~m}$, 5H), $1.94-1.81(\mathrm{~m}, 1 \mathrm{H}), 1.44(\mathrm{~s}, 9 \mathrm{H}), 0.97(\mathrm{~m}, J=8.2,6.5 \mathrm{~Hz}, 3 \mathrm{H}) .{ }^{13} \mathbf{C}$ NMR (126 MHz, CDCl $\mathbf{3}$, mixture of rotamers) $\delta 213.15,155.54,155.46,80.31,80.24,54.40,53.97,48.80,47.33,47.94$, $47.09,41.67,40.54,35.02,32.94,28.63,28.60,27.43,25.53,19.02$, 18.85. IR (neat): 2967, 2931, 2872, 1687, 1407, 1327, 1302, 1168, 1124, 897, $626 \mathrm{~cm}^{-1}$. HRMS (ESI): exact mass calculated for $[\mathrm{M}+\mathrm{Na}]^{+}\left(\mathrm{C}_{13} \mathrm{H}_{23} \mathrm{NNaO}_{3}\right)$ requires $m / z$ 264.15701, found $m / z$ 264.15697.

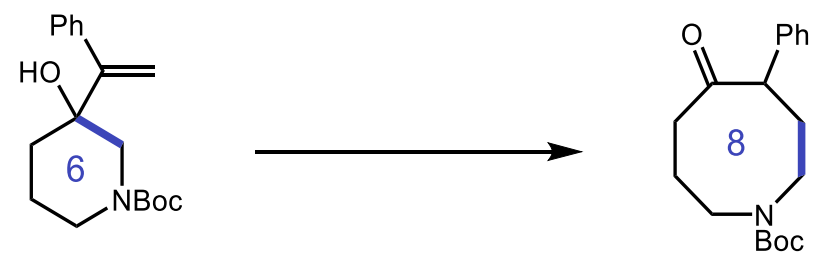

tert-butyl 5-oxo-4-phenylazocane-1-carboxylate (4a)

The titled compound was prepared on $0.5 \mathrm{mmol}$ scale following general procedure A with tertbutyl 3-hydroxy-3-(1-phenylvinyl)piperidine-1-carboxylate (4) using $\underline{\mathrm{PhCF}}_{3}$ solvent and $\underline{\mathrm{TFA}}$ base and irradiated for $5 \mathrm{~d}$. The crude material was purified by silica gel column chromatography (7\% to $60 \%$ EtOAc in hexanes) to afford the titled compound as a pale yellow solid (126 mg, $83 \%) .{ }^{1} \mathbf{H}$ NMR (500 MHz, CDCl 3 , mixture of rotamers) $\delta$ 7.37-7.27 (m, 4H), $7.23(\mathrm{~m}, 1 \mathrm{H}), 3.92-3.02$ (m, 5H), 2.79-2.32 (m, 3H), 2.30-1.82 (m, 3H), 1.51-1.49 (m, 9H). ${ }^{13} \mathbf{C}$ NMR (126 MHz, CDCl , mixture of rotamers) $\delta 211.96,211.87,155.47,138.82,138.17,128.79,128.70,128.00,127.82$, $127.29,127.26,80.29,80.25,56.70,55.15,47.45,47.12,46.82,45.98,39.63,37.14,34.60,31.80$, 28.67, 28.60, 28.25, 26.37. IR (neat): 3031, 3008, 2969, 2934, 2862, 1689, 1475, 1404, 1362 , 1288, 1183, 1106, 882, 770, 702, 641, $469 \mathrm{~cm}^{-1}$. HRMS (ESI): exact mass calculated for [M+Na] ${ }^{+}$ $\left(\mathrm{C}_{18} \mathrm{H}_{25} \mathrm{NNaO}_{3}\right)$ requires $\mathrm{m} / \mathrm{z} 326.17220$, found $\mathrm{m} / \mathrm{z} 326.17266$.

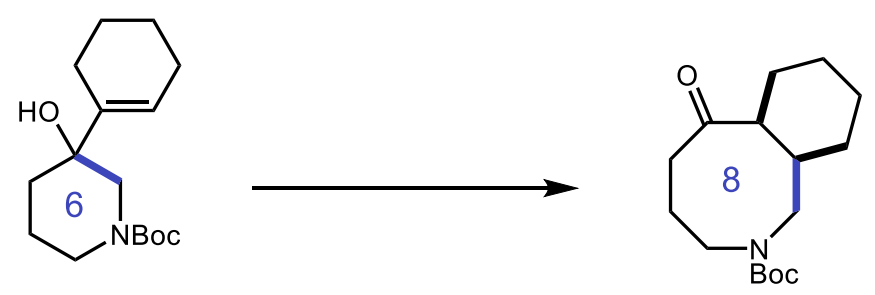

tert-butyl 6-oxodecahydrobenzo[c]azocine-2(1H)-carboxylate(5a) 
The titled compound was prepared on $0.5 \mathrm{mmol}$ scale following general procedure A with tertbutyl 3-(cyclohex-1-en-1-yl)-3-hydroxypiperidine-1-carboxylate (5) using ${\underline{\mathrm{PhCF}_{3}}}_{3}$ solvent and TFA base and irradiated for $\underline{5 \mathrm{~d}}$. The crude material was purified by silica gel column chromatography ( $7 \%$ to $60 \%$ EtOAc in hexanes) to afford the titled compound as a pale yellow solid (129 mg, 92\%, d.r. $>20: 1$ as judged by ${ }^{1} \mathrm{H}$ NMR analysis of the crude mixture). ${ }^{1} \mathbf{H}$ NMR (400 MHz, DMSO- $\left.\boldsymbol{d}_{\mathbf{6}}, \mathbf{1 2 0}^{\circ} \mathrm{C}\right) \delta 3.97(\mathrm{t}, \mathrm{J}=13.6 \mathrm{~Hz}, 1 \mathrm{H}), 3.48(\mathrm{dt}, \mathrm{J}=14.1,3.6 \mathrm{~Hz}, 1 \mathrm{H}), 2.97-2.87$ (m, 2H), 2.73-2.63 (m, 1H), 2.30-2.15 (m, 2H), 2.01-1.93 (m, 1H), 1.81-1.15 (m, 19H). ${ }^{13}$ C NMR (101 MHz, DMSO- $\left.\boldsymbol{d}_{\mathbf{6}}, \mathbf{1 2 0}^{\circ} \mathrm{C}\right) \delta 211.65,153.58,78.09,51.19,46.55,46.47,36.13,33.70,27.56$, 27.52, 27.36, 24.33, 19.97, 19.81. IR (neat): 2968, 2923, 2868, 2860, 1684, 1409, 1364, 1226, $1169,699 \mathrm{~cm}^{-1}$. HRMS (ESI): exact mass calculated for $[\mathrm{M}+\mathrm{Na}]^{+}\left(\mathrm{C}_{16} \mathrm{H}_{27} \mathrm{NNaO}_{3}\right)$ requires $\mathrm{m} / \mathrm{z}$ 304.18831, found $\mathrm{m} / \mathrm{z} 304.18851$.

Crystal data of 5a (Figure S6): Compound 5a was recrystallized from $n$-hexanesdichloromethane at room temperature in 2 days. Formula $\mathrm{C}_{16} \mathrm{H}_{27} \mathrm{NO}_{3}$, colorless, crystal dimensions $0.428 \times 0.384 \times 0.316 \mathrm{~mm}^{3}$, monoclinic, space group $P 12_{1} / c, a=15.3169(12) \AA, b=8.6950(7)$ $\AA, c=11.7020(9) \AA, \quad=90^{\circ}, \quad=102.1310(16)^{\circ}, \quad=90^{\circ}, V=1523.68 \AA^{3}, Z=4, \quad$ calc $=1.227 \mathrm{~g}$ $\mathrm{cm}^{-3}, \mathrm{~F}(000)=616, \quad(\mathrm{MoK} \quad)=0.083 \mathrm{~mm}^{-1}, T=100 \mathrm{~K} .47137$ reflections collected, 6383 independent reflections with $I>2 \quad(I)\left(2 \max =68.68^{\circ}\right)$, and 184 parameters were used for the solution of the structure. The non-hydrogen atoms were refined anisotropically. $R_{1}=0.0421$ and $w R_{2}=0.1099$. GOF $=1.063$. Crystallographic data (excluding structure factors) for the structure reported in this paper have been deposited with the Cambridge Crystallographic Data Centre as supplementary publication no. CCDC-1900667. Copies of the data can be obtained free of charge on application to CCDC, 12 Union Road, Cambridge CB2 1EZ, UK [Web page: http://www.ccdc.cam.ac.uk/].

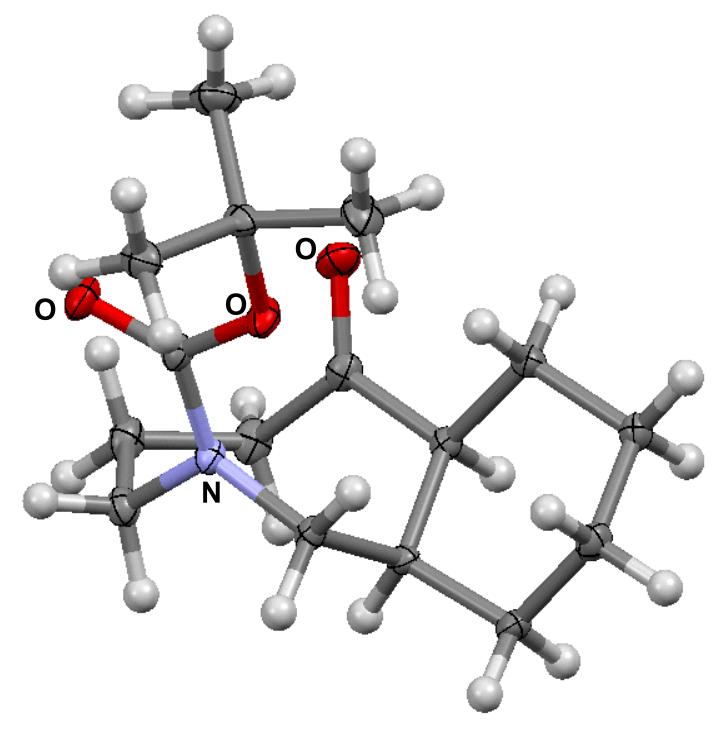

Figure S6. ORTEP drawing of 5a 


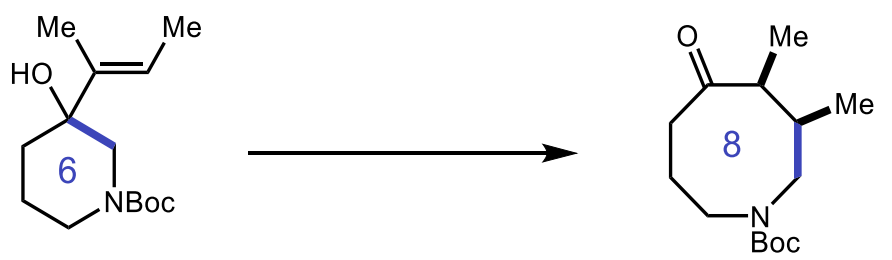

tert-butyl 3,4-dimethyl-5-oxoazocane-1-carboxylate (6a)

The titled compound was prepared on $0.5 \mathrm{mmol}$ scale following general procedure A with tertbutyl (E)-3-(but-2-en-2-yl)-3-hydroxypiperidine-1-carboxylate (6) using $\underline{\mathrm{PhCF}_{3}}$ solvent and TFA base and irradiated for $5 \mathrm{~d}$. The crude material was purified by silica gel column chromatography (7\% to $60 \%$ EtOAc in hexanes) to afford the titled compound as a pale yellow solid (106 $\mathrm{mg}, 83 \%$, d.r. $>20: 1$ as judged by $1 \mathrm{H}$ NMR analysis of the crude mixture). ${ }^{1}$ H NMR (400 MHz, DMSO- $\boldsymbol{d}_{6}$, $\left.120{ }^{\circ} \mathrm{C}\right) \delta 3.57-3.42(\mathrm{~m}, 2 \mathrm{H}), 2.94-2.86(\mathrm{~m}, 2 \mathrm{H}), 2.79-2.65(\mathrm{~m}, 2 \mathrm{H}), 2.32(\mathrm{qd}, \mathrm{J}=6.8,3.5 \mathrm{~Hz}$, 1H), 2.20 (dddt, J = 13.8, 12.8, 11.9, $4.0 \mathrm{~Hz}, 1 \mathrm{H}), 2.01$ (dddd, $\mathrm{J}=12.0,4.9,3.9,0.9 \mathrm{~Hz}, 1 \mathrm{H}), 1.77-$ $1.69(\mathrm{~m}, 1 \mathrm{H}), 1.40(\mathrm{~s}, 9 \mathrm{H}), 0.97(\mathrm{~d}, \mathrm{~J}=6.8 \mathrm{~Hz}, 3 \mathrm{H}), 0.94(\mathrm{~d}, \mathrm{~J}=6.9 \mathrm{~Hz}, 3 \mathrm{H}) .{ }^{\mathbf{1 3}} \mathbf{C}$ NMR (101 MHz, DMSO-d $\left.\boldsymbol{d}_{6} \mathbf{1 2 0}^{\circ} \mathrm{C}\right) \delta 211.97,153.47,78.09,48.52,48.50,46.39,36.36,32.36,27.58,27.50,15.35$, 5.64. IR (neat): 2971, 2932, 1687, 1408, 1327, 1266, 1160, 762, $402 \mathrm{~cm}^{-1}$. HRMS (ESI): exact mass calculated for $[\mathrm{M}+\mathrm{Na}]^{+}\left(\mathrm{C}_{14} \mathrm{H}_{25} \mathrm{NNaO}_{3}\right)$ requires $m / z$ 278.17266, found $m / z 278.17297$.

Crystal data of 6a (Figure S7): Compound 6a was recrystallized from $n$-hexanesdichloromethane at room temperature for 1 days. Formula $\mathrm{C}_{14} \mathrm{H}_{25} \mathrm{NO}_{3}$, colorless, crystal dimensions $0.39 \times 0.26 \times 0.22 \mathrm{~mm}^{3}$, monoclinic, space group $P 12{ }_{1} / c, a=12.5640(5) \AA, b=$ 9.2554(4) $\AA, c=12.3410(5) \AA, \quad=90^{\circ}, \quad=91.5498(12)^{\circ}, \quad=90^{\circ}, V=1434.55(10) \AA^{3}, Z=1$, calc $=1.182 \mathrm{~g} \mathrm{~cm}^{-3}, \mathrm{~F}(000)=560.0, \quad(\mathrm{CuK})=0.658 \mathrm{~mm}^{-1}, T=100 \mathrm{~K} .15321$ reflections collected, 2620 independent reflections with $I>2$ (I) $\left(2 \max =140.1782^{\circ}\right)$, and 168 parameters were used for the solution of the structure. The non-hydrogen atoms were refined anisotropically. $R_{1}=0.0337$ and $w R_{2}=0.0796 . \mathrm{GOF}=1.034$. Crystallographic data (excluding structure factors) for the structure reported in this paper have been deposited with the Cambridge Crystallographic Data Centre as supplementary publication no. CCDC-1900665. Copies of the data can be obtained free of charge on application to CCDC, 12 Union Road, Cambridge CB2 1EZ, UK [Web page: http://www.ccdc.cam.ac.uk/]. 


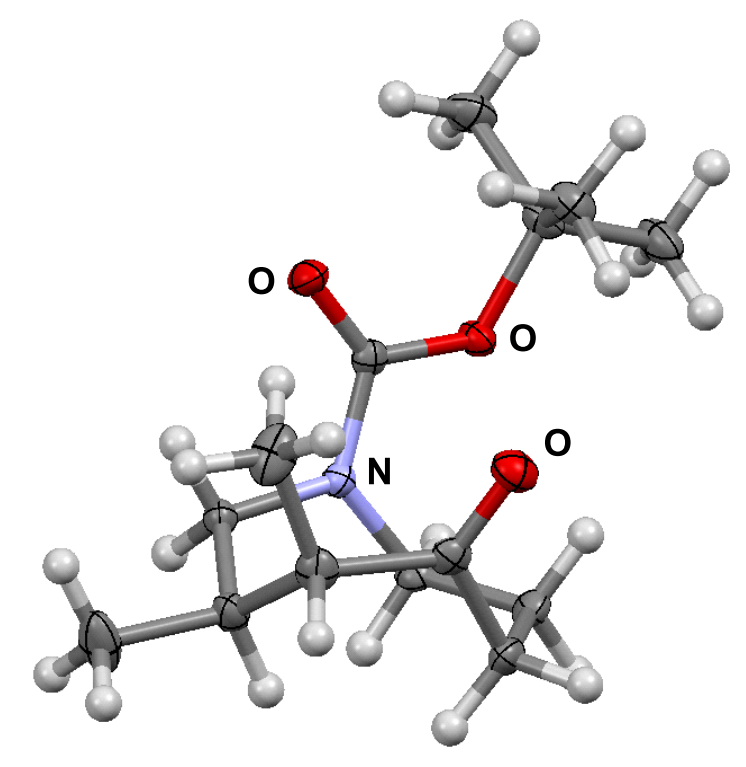

Figure S7. ORTEP drawing of 6a

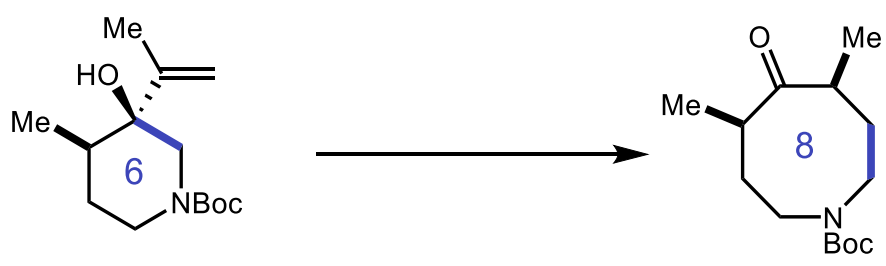

tert-butyl 4,6-dimethyl-5-oxoazocane-1-carboxylate (7a)

The titled compound was prepared on $0.5 \mathrm{mmol}$ scale following general procedure A with tertbutyl 3-hydroxy-4-methyl-3-(prop-1-en-2-yl)piperidine-1-carboxylate (7) using $\mathrm{PhCF}_{3}$ solvent and TFA base and irradiated for $\underline{5 \mathrm{~d}}$. The crude material was purified by silica gel column chromatography (7\% to $60 \%$ EtOAc in hexanes) to afford the titled compound as a pale yellow solid (93.0 mg, 73\%, d.r. $>20: 1$ as judged by $1 \mathrm{H}$ NMR analysis of the crude mixture). ${ }^{1} \mathbf{H}$ NMR $\left(\mathbf{5 0 0} \mathbf{M H z}, \mathbf{C D C l}_{3}\right.$, mixture of rotamers) $\delta 3.91(\mathrm{~m}, 1 \mathrm{H}), 3.75(\mathrm{~m}, 1 \mathrm{H}), 2.84-2.57(\mathrm{~m}, 4 \mathrm{H}), 2.15-$ $1.92(\mathrm{~m}, 4 \mathrm{H}), 1.45(\mathrm{~s}, 9 \mathrm{H}), 1.07(\mathrm{~d}, J=6.6 \mathrm{~Hz}, 6 \mathrm{H}) \cdot{ }^{\mathbf{1 3}} \mathbf{C} \mathbf{~ N M R}\left(\mathbf{1 2 6} \mathbf{~ M H z}, \mathbf{C D C l}_{3}\right.$, mixture of rotamers) $\delta 217.40,155.10,79.98,45.39,44.81,43.04,42.65,35.17,34.01,28.55,15.61,15.26$. IR (neat): 2973, 2930, 1687, 1408, 1364, 1247, 1149, 760, $444 \mathrm{~cm}^{-1}$. HRMS (ESI): exact mass calculated for $[\mathrm{M}+\mathrm{Na}]^{+}\left(\mathrm{C}_{14} \mathrm{H}_{25} \mathrm{NNaO}_{3}\right)$ requires $m / z 278.17266$, found $m / z 278.17261$.

Crystal data of 6a (Figure S8): Compound 7a was sublimated and condensed at room temperature for 3 weeks. Formula $\mathrm{C}_{14} \mathrm{H}_{25} \mathrm{NO}_{3}$, colorless, crystal dimensions $0.390 \times 0.168 \times 0.164$ $\mathrm{mm}^{3}$, monoclinic, space group $C 1 c 1$ (\#9), $a=6.67270(10) \AA, b=17.8456(4) \AA, c=12.3622(3)$ $\AA, \quad=90^{\circ}, \quad=98.4333(7)^{\circ}, \quad=90^{\circ}, V=1456.15(5) \AA^{3}, Z=4, \quad$ calc $=1.165 \mathrm{~g} \mathrm{~cm}^{-3}, \mathrm{~F}(000)=$ 560, $(\mathrm{CuK})=0.648 \mathrm{~mm}^{-1}, T=100 \mathrm{~K} .2494$ reflections collected, 10993 independent reflections with $I>2$ (I) $\left(2 \max =113.12^{\circ}\right)$, and 168 parameters were used for the solution of the structure. The non-hydrogen atoms were refined anisotropically. $R_{1}=0.0222$ and $w R_{2}=0.0548$. 
$\mathrm{GOF}=1.074$. Crystallographic data (excluding structure factors) for the structure reported in this paper have been deposited with the Cambridge Crystallographic Data Centre as supplementary publication no. CCDC-1900666. Copies of the data can be obtained free of charge on application to CCDC, 12 Union Road, Cambridge CB2 1EZ, UK [Web page: http://www.ccdc.cam.ac.uk/].

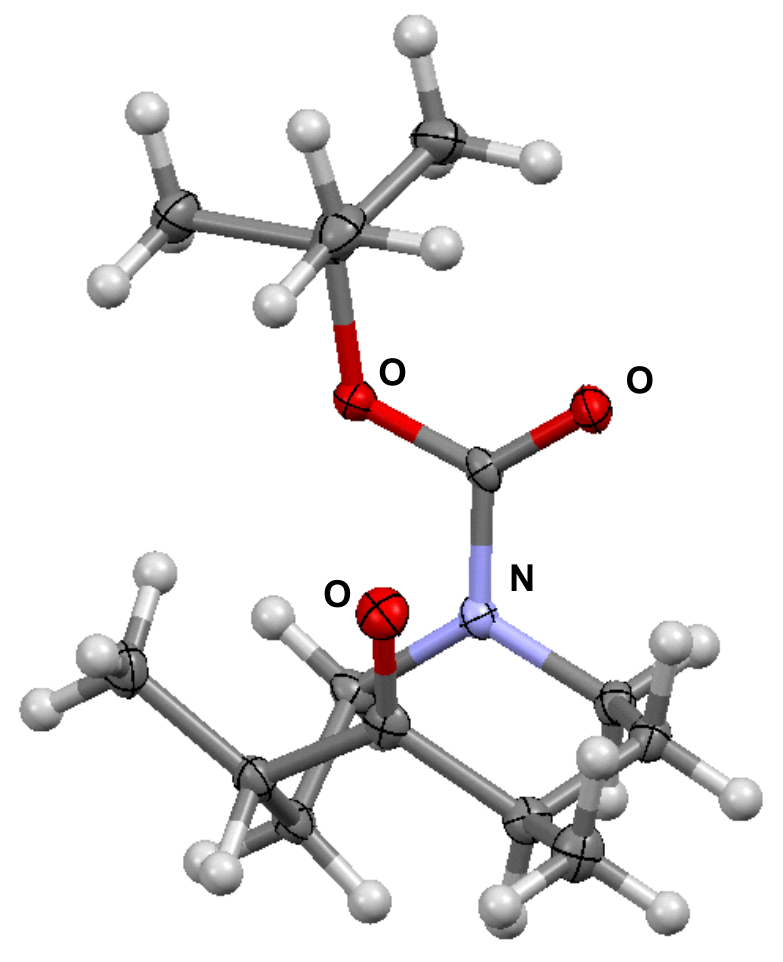

Figure S8. ORTEP drawing of 7a
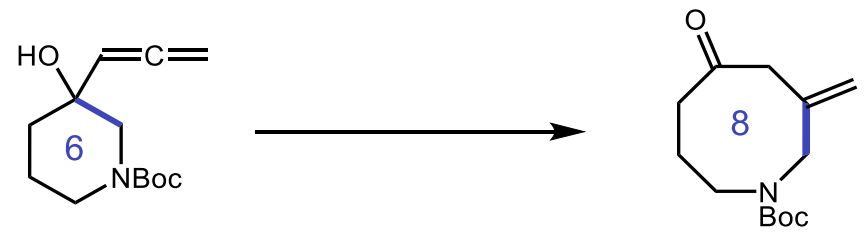

tert-butyl 3-methylene-5-oxoazocane-1-carboxylate (9a)

The titled compound was prepared on $0.5 \mathrm{mmol}$ scale following general procedure A with tertbutyl 3-hydroxy-3-(propa-1,2-dien-1-yl)piperidine-1-carboxylate (9) using PhMe solvent and TFA base and irradiated for $3 \mathrm{~d}$. The crude material was purified by silica gel column chromatography ( $7 \%$ to $60 \%$ EtOAc in hexanes) to afford an inseparable mixture of starting material and the titled compound in $80 \%$ NMR yield. This mixture is then submitted to the following alcohol protection condition to remove the remaining starting material. ${ }^{27}$ 
To a $10-\mathrm{mL}$ round-bottomed flask, charged with a stir bar, is added a $N, N$-dimethylformamide (3.0 $\mathrm{mL})$ solution of the previously obtained mixture, followed by imidazole $(51.0 \mathrm{mg}, 0.75 \mathrm{mmol})$ and trimethylsilyl chloride $(63.0 \mu \mathrm{L}, 0.5 \mathrm{mmol})$. The resulting mixture is then stirred overnight under argon at room temperature. Afterwards, the reaction was quenched with sat. aq. $\mathrm{NH}_{4} \mathrm{Cl}$ solution and then extracted by $\mathrm{Et}_{2} \mathrm{O}$ for three times. The combined organic layers are dried over $\mathrm{MgSO}_{4}$, filtered and concentrated to a small volume, then purified by silica gel flash column chromatography (7\% to $60 \%$ EtOAc in hexanes) to afford the titled compound as a pale yellow solid (84.0 mg, 70\%). The starting material is recovered as trimethylsilyl ether, which is less polar than the product. ${ }^{1} \mathbf{H}$ NMR (500 $\mathbf{~ M H z , ~} \mathbf{C D C l}_{3}$, mixture of rotamers) $\delta 5.31-4.99(\mathrm{~m}, 2 \mathrm{H}), 3.93$ $(\mathrm{m}, 2 \mathrm{H}), 3.19(\mathrm{~m}, 2 \mathrm{H}), 3.05(\mathrm{~s}, 2 \mathrm{H}), 2.37(\mathrm{t}, J=6.2 \mathrm{~Hz}, 2 \mathrm{H}), 2.13-1.95(\mathrm{~m}, 2 \mathrm{H}), 1.45(\mathrm{~s}, 9 \mathrm{H}) .{ }^{13} \mathrm{C}$ NMR (126 MHz, CDCl 3 , mixture of rotamers) $\delta$ 210.70, 210.26, 155.36, 154.54, 142.54, 118.35, 117.94, 80.41, 54.99, 54.05, 51.67, 51.51, 47.64, 47.57, 37.78, 37.06, 28.56, 28.52, 28.51, 27.86. IR (neat): 2972, 2931, 1689, 1406, 1393, 1244, 1183, 1027, 896, $766 \mathrm{~cm}^{-1}$. HRMS (ESI): exact mass calculated for $[\mathrm{M}+\mathrm{Na}]^{+}\left(\mathrm{C}_{13} \mathrm{H}_{21} \mathrm{NNaO}_{3}\right)$ requires $m / z$ 262.14136, found $m / z 262.14122$.

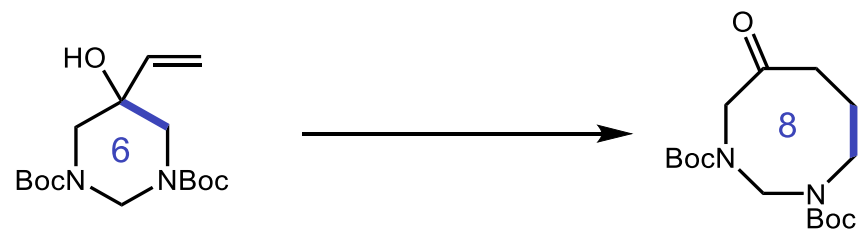

\section{di-tert-butyl 5-oxo-1,3-diazocane-1,3-dicarboxylate (10a)}

The titled compound was prepared on $0.5 \mathrm{mmol}$ scale following general procedure A with di-tertbutyl 5-hydroxy-5-vinyldihydropyrimidine-1,3(2H,4H)-dicarboxylate (10) using PhMe solvent and TFA base and irradiated for $\underline{3 \mathrm{~d}}$. The crude material was purified by silica gel column chromatography (7\% to $60 \%$ EtOAc in hexanes) to afford the titled compound as a white solid (115 mg, 70\%). ${ }^{1} \mathbf{H}$ NMR (500 $\mathbf{~ M H z , ~} \mathbf{C D C l}_{3}$, mixture of rotamers) $\delta 5.06-4.83(\mathrm{~m}, 2 \mathrm{H}), 4.05-$ 3.61 (br, 2H), 3.26 (br, 2H), 2.36 (br, 2H), 2.10-1.94 (br, 2H), 1.51 (br, 9H), 1.44 (s, 9H). ${ }^{13} \mathrm{C}$ NMR (126 MHz, $\mathbf{C D C l}_{3}$, mixture of rotamers) $\delta$ 212.88, 212.56, 154.54, 81.65, 81.57, 81.04, 61.09, 60.26, 59.38, 55.57, 55.28, 55.02, 54.79, 48.04, 47.87, 37.87, 37.64, 28.55, 28.48, 28.41. IR (neat): 2970, 2922, 1707, 1684, 1466, 1424, 1286, 1141, 894, 774, 525, $477 \mathrm{~cm}^{-1}$. HRMS (ESI): exact mass calculated for $[\mathrm{M}+\mathrm{Na}]^{+}\left(\mathrm{C}_{16} \mathrm{H}_{28} \mathrm{~N}_{2} \mathrm{NaO}_{5}\right)$ requires $\mathrm{m} / z$ 351.18860, found $\mathrm{m} / \mathrm{z}$ 351.18904 .
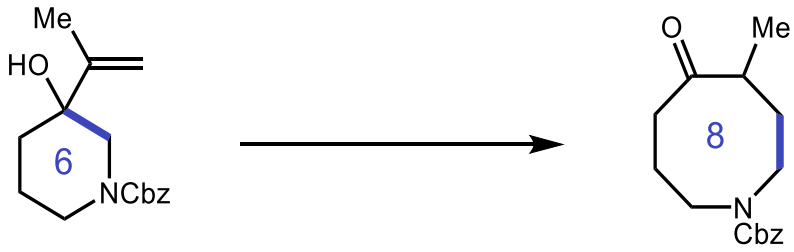

benzyl 4-methyl-5-oxoazocane-1-carboxylate (11a)

The titled compound was prepared on $0.5 \mathrm{mmol}$ scale following general procedure A with benzyl 3-hydroxy-3-(prop-1-en-2-yl)piperidine-1-carboxylate (11) using $\underline{\mathrm{PhCF}_{3}}$ solvent and $\underline{\mathrm{TFA}}$ base and irradiated for $5 \mathrm{~d}$. The crude material was purified by silica gel column chromatography (7\% to $60 \%$ EtOAc in hexanes) to afford the titled compound as a pale yellow solid (103 $\mathrm{mg}, 75 \%) .{ }^{1} \mathbf{H}$ NMR (500 MHz, CDCl 3 , mixture of rotamers) $\delta$ 7.40-7.34 (m, 4H), 7.34-7.28 (m, 1H), $5.10(\mathrm{~s}$, 
2H), 3.71-3.39 (m, 2H), 3.26-3.04 (m, 2H), 2.68-1.88 (m, 7H), 1.14-1.03 (m, 3H). ${ }^{13} \mathbf{C}$ NMR $\left(126 \mathrm{MHz}, \mathbf{C D C l}_{3}\right.$, mixture of rotamers) $\delta 216.32,216.25,156.15,156.01,136.84,136.80$, $128.57,128.20,128.14,128.06,67.53,67.51,47.85,47.34,45.83,45.69,44.49,43.69,39.00$, $38.02,34.99,33.50,27.94,26.36,16.24,15.71$. IR (neat): 2931, 2871, 1690, 1446, 1414, 1345, 1123, 734, 696, $460 \mathrm{~cm}^{-1}$. HRMS (ESI): exact mass calculated for $[\mathrm{M}+\mathrm{H}]^{+}\left(\mathrm{C}_{16} \mathrm{H}_{22} \mathrm{NO}_{3}\right)$ requires $\mathrm{m} / \mathrm{z} 276.15933$, found $\mathrm{m} / \mathrm{z} 276.15942$.

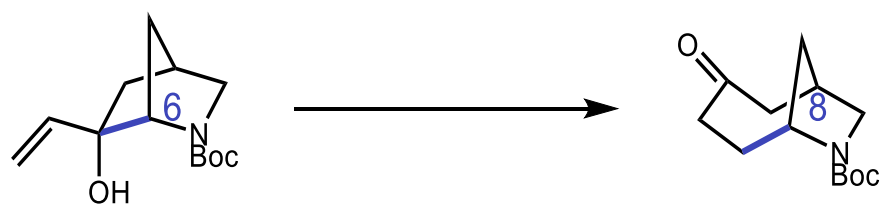

tert-butyl $\left(1 R^{*}, 6 R^{*}\right)-3-0 x 0-7-a z a b i c y c l o[4.2 .1]$ nonane-7-carboxylate (12a)

The titled compound was prepared on $0.5 \mathrm{mmol}$ scale following general procedure B with $5 \mathrm{~mol} \%$ Iridium photocatalyst loading and tert-butyl $\left(1 S^{*}, 4 R^{*}, 6 S^{*}\right)$-6-hydroxy-6-vinyl-2azabicyclo[2.2.1]heptane-2-carboxylate (12) using $\underline{0.1 \mathrm{M}} \underline{\mathrm{PhCF}_{3}}$ solvent and $\underline{\mathrm{TFA}}$ base and irradiated for $6 \mathrm{~d}$ with one fan. The crude material was purified by silica gel column chromatography (7\% to $60 \%$ EtOAc in hexanes) to afford the titled compound as a pale yellow solid (49.0 mg, 41\%). ${ }^{\mathbf{1}} \mathbf{H}$ NMR (500 $\mathbf{~ M H z , ~} \mathbf{C D C l}_{3}$, mixture of rotamers) $\delta 4.30-4.14(\mathrm{~m}, 1 \mathrm{H})$, 3.73-3.48 (m, 1H), 3.45-3.26 (m, 1H), 2.67-2.39 (m, 5H), 2.36-2.15 (m, 2H), 1.77-1.59 (m, 2H), $1.49-1.42(\mathrm{~m}, 9 \mathrm{H}) .{ }^{\mathbf{1 3}} \mathbf{C} \mathbf{N M R}\left(\mathbf{1 2 6} \mathbf{~ M H z}, \mathbf{C D C l}_{3}\right.$, mixture of rotamers) $\delta 212.09,212.03,154.24$, $154.16,79.76,79.67,56.09,55.75,54.04,53.46,50.93,50.87,39.00,38.95,35.85,34.59,32.23$, 30.84, 30.65, 28.67, 28.64. IR (neat): 2966, 2883, 1687, 1390, 1364, 1161, 1109, 868, 762, 548

$\mathrm{cm}^{-1}$. HRMS (EI): exact mass calculated for $[\mathrm{M}]^{+}\left(\mathrm{C}_{13} \mathrm{H}_{21} \mathrm{NO}_{3}\right)$ requires $\mathrm{m} / z 239.15159$, found $m / z 239.15177$.

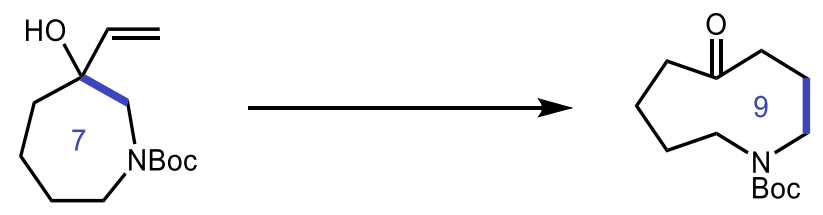

tert-butyl 5-oxoazonane-1-carboxylate (13a)

The titled compound was prepared on $0.5 \mathrm{mmol}$ scale following general procedure A with tertbutyl 3-hydroxy-3-vinylazepane-1-carboxylate (13) using $\underline{\mathrm{PhCF}_{3}}$ solvent and TFA base and irradiated for $5 \mathrm{~d}$. The crude material was purified by silica gel column chromatography (7\% to $60 \%$ EtOAc in hexanes) to afford the titled compound as a pale yellow solid $(58.0 \mathrm{mg}, 48 \%) .{ }^{1} \mathbf{H}$ NMR (500 MHz, CDCl 3 , mixture of rotamers) $\delta 3.28-2.99$ (br, 4H), 2.47-2.37 (m, 4H), 2.162.01 (br, 2H), 1.93-1.86 (br, 2H), 1.79-1.63 (br, 2H), 1.53-1.42 (br, 9H). ${ }^{13} \mathbf{C}$ NMR (126 MHz, $\mathrm{CDCl}_{3}$, mixture of rotamers) $\delta 213.44,212.99,156.61,156.23,79.87,52.07,51.80,50.27,50.11$, $45.80,45.38,38.68,37.98,28.58,28.03,27.12,25.25,24.68,23.50$. IR (neat): 2926, 2865, 1667, 1477, 1408, 1363, 1155, 1085, 776, $479 \mathrm{~cm}^{-1}$. HRMS (ESI): exact mass calculated for [M+H] $\left(\mathrm{C}_{13} \mathrm{H}_{24} \mathrm{NO}_{3}\right)$ requires $\mathrm{m} / z$ 242.17507, found $\mathrm{m} / z$ 242.17518. 


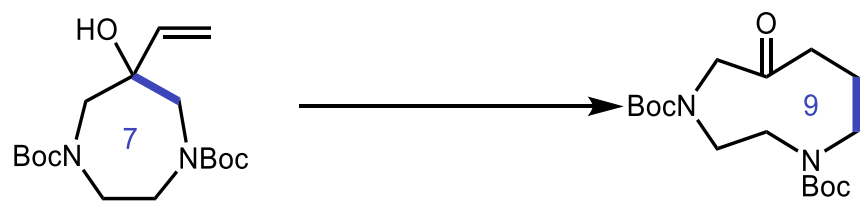

\section{di-tert-butyl 6-oxo-1,4-diazonane-1,4-dicarboxylate (14a)}

The titled compound was prepared on $0.5 \mathrm{mmol}$ scale following general procedure A with di-tertbutyl 6-hydroxy-6-vinyl-1,4-diazepane-1,4-dicarboxylate (14) using $\mathrm{PhCF}_{3}$ solvent and TFA base and irradiated for $5 \mathrm{~d}$. The crude material was purified by silica gel column chromatography (7\% to $60 \%$ EtOAc in hexanes) to afford a mixture of starting material and the titled compound in $65 \%$ NMR yield. The mixture is then submitted to the following alcohol protection to remove the remaining starting material. ${ }^{26}$

To a 10-mL round-bottomed flask, charged with a stir bar, is added a $N, N$-dimethylformamide (3.0 $\mathrm{mL})$ solution of the previously obtained mixture, followed by imidazole $(51.0 \mathrm{mg}, 0.75 \mathrm{mmol})$ and trimethylsilyl chloride $(63.0 \mu \mathrm{L}, 0.5 \mathrm{mmol})$. The resulting mixture is then stirred overnight under argon at room temperature. Afterwards, the reaction was quenched with sat. aq. $\mathrm{NH}_{4} \mathrm{Cl}$ solution and then extracted by $\mathrm{Et}_{2} \mathrm{O}$ for three times. The combined organic layers are dried over $\mathrm{MgSO}_{4}$, filtered and concentrated to a small volume, then purified by silica gel flash column chromatography (7\% to $60 \%$ EtOAc in hexanes) to afford the titled compound as a pale yellow solid $(99.0 \mathrm{mg}, 58 \%)$. The starting material is recovered as trimethylsilyl ether, which is less polar than the product. ${ }^{1} \mathbf{H}$ NMR (500 $\mathbf{~ M H z , ~} \mathbf{C D C l}_{3}$, mixture of rotamers) $\delta$ 4.07-3.85 (m, 2H), 3.58$3.06(\mathrm{~m}, 6 \mathrm{H}), 2.52-2.34$ (br, 2H), 2.12-2.05 (br, 2H), 1.53-1.49 (m, 9H), 1.49-1.45 (m, 9H). ${ }^{13} \mathrm{C}$ NMR (126 MHz, $\mathbf{C D C l}_{3}$, mixture of rotamers) $\delta$ 209.10, 208.91, 207.75, 156.02, 155.64, 155.46, $154.84,80.96,80.78,80.61,80.50,80.38,61.92,61.64,61.33,61.10,53.84,53.26,52.56,51.59$, $49.67,49.43,49.20,48.99,37.38,36.14,35.96,28.65,28.61,28.56,28.43,28.42,27.48,27.08$, 26.28, 25.99. IR (neat): 2969, 2916, 1685, 1461, 1407, 1362, 1246, 1153, 1106, 952, 774, 511, $462 \mathrm{~cm}^{-1}$. HRMS (ESI): exact mass calculated for $[\mathrm{M}+\mathrm{Na}]^{+}\left(\mathrm{C}_{17} \mathrm{H}_{30} \mathrm{~N}_{2} \mathrm{NaO}_{5}\right)$ requires $\mathrm{m} / z$ 365.20469, found $\mathrm{m} / \mathrm{z} 365.20424$.
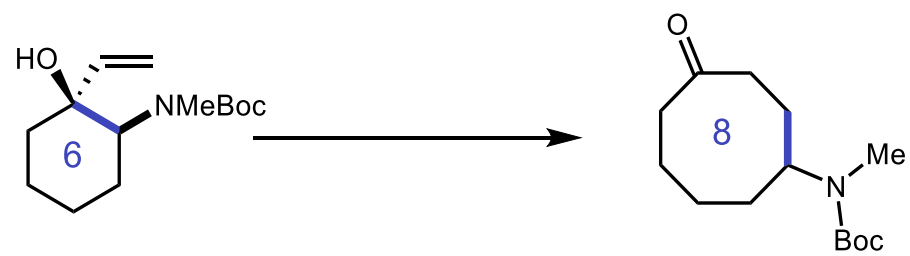

tert-butyl methyl(4-oxocyclooctyl)carbamate (15a)

The titled compound was prepared on $0.5 \mathrm{mmol}$ scale following general procedure A with tertbutyl $\left(\left(1 S^{*}, 2 S^{*}\right)\right.$-2-hydroxy-2-vinylcyclohexyl)(methyl)carbamate (15) using $\mathrm{PhCF}_{3}$ solvent and

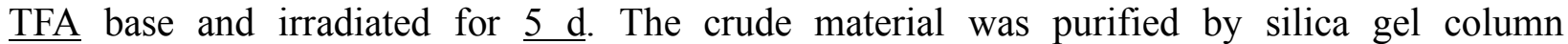
chromatography (7\% to $60 \%$ EtOAc in hexanes) to afford the titled compound as a pale yellow solid (57.5 mg, 45\%). ${ }^{1} \mathbf{H}$ NMR (500 MHz, DMSO-d $\left.\mathbf{6} \mathbf{1 2 0}^{\circ} \mathbf{C}\right) \delta 3.87$ (ddt, $J=10.8,7.8,3.0 \mathrm{~Hz}$, $1 \mathrm{H}), 2.70(\mathrm{~s}, 3 \mathrm{H}), 2.56(\mathrm{ddd}, J=13.3,10.9,3.9 \mathrm{~Hz}, 1 \mathrm{H}), 2.43-2.34(\mathrm{~m}, 3 \mathrm{H}), 2.10-1.46(\mathrm{~m}, 7 \mathrm{H})$, $1.45-1.38(\mathrm{~m}, 10 \mathrm{H}) .{ }^{13} \mathbf{C}$ NMR (126 MHz, DMSO-d , $\left.^{120}{ }^{\circ} \mathrm{C}\right) \delta 214.15,153.94,77.95,54.95$, 41.49, 38.22, 30.76, 30.09, 28.99, 27.65, 25.21, 23.65. IR (neat): 2931, 1683, 1447, 1391, 1384, 
$1319,1138,878,771,622 \mathrm{~cm}^{-1}$. HRMS (ESI): exact mass calculated for $[\mathrm{M}+\mathrm{H}]^{+}\left(\mathrm{C}_{14} \mathrm{H}_{26} \mathrm{NO}_{3}\right)$ requires $\mathrm{m} / \mathrm{z} 256.19072$, found $\mathrm{m} / \mathrm{z} 256.19054$.
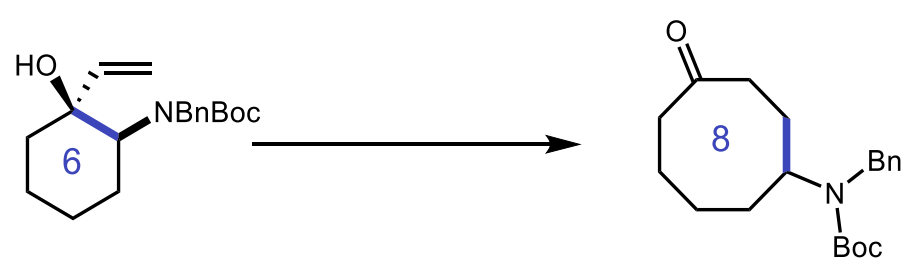

tert-butyl benzyl(4-oxocyclooctyl)carbamate (16a)

The titled compound was prepared on $0.5 \mathrm{mmol}$ scale following general procedure A with tertbutyl benzyl $\left(\left(1 S^{*}, 2 S^{*}\right)\right.$-2-hydroxy-2-vinylcyclohexyl)carbamate (16) using $\underline{\mathrm{PhCF}}_{3}$ solvent and $\underline{\mathrm{dPh}}$ base and irradiated for $\underline{5 \mathrm{~d}}$. The crude material was purified by silica gel column chromatography ( $7 \%$ to $60 \%$ EtOAc in hexanes) to afford the titled compound as a pale yellow solid (91.1 $\mathrm{mg}$, 55\%). ${ }^{1} \mathbf{H}$ NMR (500 MHz, DMSO-d6, $\left.100{ }^{\circ} \mathrm{C}\right) \delta 7.33(\mathrm{t}, J=7.6 \mathrm{~Hz}, 2 \mathrm{H}), 7.28-7.21(\mathrm{~m}, 3 \mathrm{H})$, $4.45(\mathrm{~d}, J=15.9 \mathrm{~Hz}, 1 \mathrm{H}), 4.30(\mathrm{~d}, J=15.9 \mathrm{~Hz}, 1 \mathrm{H}), 3.63(\mathrm{dd}, J=11.9,7.4 \mathrm{~Hz}, 1 \mathrm{H}), 2.96(\mathrm{~s}, 1 \mathrm{H})$, $2.59-2.48(\mathrm{~m}, 2 \mathrm{H}), 2.39-2.21(\mathrm{~m}, 3 \mathrm{H}), 2.12(\mathrm{dtd}, J=14.6,11.2,3.5 \mathrm{~Hz}, 1 \mathrm{H}), 1.96-1.77(\mathrm{~m}, 2 \mathrm{H})$, 1.69 (dddt, $J=18.7,11.4,7.5,3.7 \mathrm{~Hz}, 1 \mathrm{H}), 1.61-1.45(\mathrm{~m}, 2 \mathrm{H}), 1.45(\mathrm{~s}, 9 \mathrm{H}) .{ }^{13} \mathbf{C}$ NMR (126 MHz, DMSO-d6, $\left.\mathbf{1 0 0}^{\circ} \mathrm{C}\right) \delta 214.11,154.18,139.30,127.56,126.41,126.04,78.40,56.85,48.50,41.71$, 38.02, 31.91, 31.06, 27.59, 25.38, 23.04. IR (neat): 2931, 1682, 1445, 1391, 1352, 1139, 876, 841, $771,622 \mathrm{~cm}^{-1}$. HRMS (ESI): exact mass calculated for $[\mathrm{M}+\mathrm{Na}]^{+}\left(\mathrm{C}_{20} \mathrm{H}_{29} \mathrm{NNaO}_{3}\right)$ requires $\mathrm{m} / \mathrm{z}$ 354.20396, found $m / z 354.20395$.

\section{$\underline{\text { n+1 Ring Expansion }}$}

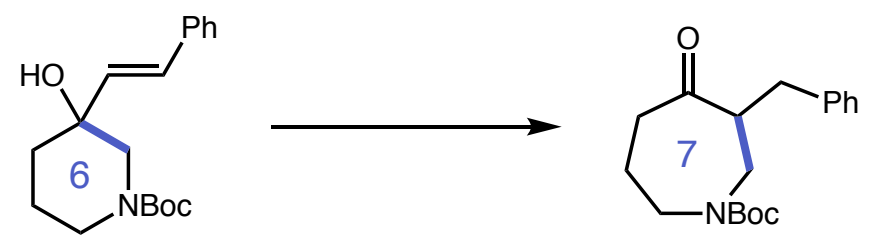

tert-Butyl 3-benzyl-4-oxoazepane-1-carboxylate (17a)

The titled compound was prepared on $0.5 \mathrm{mmol}$ scale following general procedure B with tertbutyl (E)-3-hydroxy-3-styrylpiperidine-1-carboxylate (17) using $\mathrm{PhCF}_{3}(10 \mathrm{~mL})$ solvent, TFA base ( $25 \mathrm{~mol} \%$ ), and TRIP-SH (5 mol\%), and irradiated for $\underline{6 \mathrm{~d}}$ at $35^{\circ} \mathrm{C}$ (with a fan to cool the reaction setup). The crude material was purified by silica gel column chromatography ( $2 \%$ to $18 \%$ EtOAc in hexanes) to afford the titled compound as a colorless oil (121 mg, 80\%). ${ }^{1} \mathbf{H}$ NMR (400 MHz, DMSO- $\left.\boldsymbol{d}_{6}, \mathbf{1 2 0}^{\circ} \mathrm{C}\right) \delta 7.30-7.26(\mathrm{~m}, 2 \mathrm{H}), 7.21-7.17(\mathrm{~m}, 3 \mathrm{H}), 3.80(\mathrm{dt}, J=14.1,4.7 \mathrm{~Hz}, 1 \mathrm{H})$, 3.72 (dd, $J=14.1,5.2 \mathrm{~Hz}, 1 \mathrm{H}), 3.15-2.93(\mathrm{~m}, 4 \mathrm{H}), 2.70-2.62(\mathrm{~m}, 2 \mathrm{H}), 2.43(\mathrm{~m}, 1 \mathrm{H}), 1.80-1.64$ $(\mathrm{m}, 2 \mathrm{H}), 1.37$ (s, 9H). ${ }^{13} \mathbf{C}$ NMR (101 MHz, DMSO-d $\left.\mathbf{6}, \mathbf{1 2 0}^{\circ} \mathbf{C}\right) \delta 210.82,153.33,138.51,128.02$, $127.50,125.32,78.35,52.99,47.20,46.81,40.00,34.43,27.38,24.08$. IR (neat): 2974, 1686, 1467, 1412, 1242, 1155, 924, 757, $698 \mathrm{~cm}^{-1}$. HRMS (ESI): exact mass calculated for $[\mathrm{M}+\mathrm{H}]^{+}$ $\left(\mathrm{C}_{18} \mathrm{H}_{26} \mathrm{NO}_{3}\right)$ requires $\mathrm{m} / \mathrm{z} 304.19072$, found $\mathrm{m} / \mathrm{z} 304.19055$. 


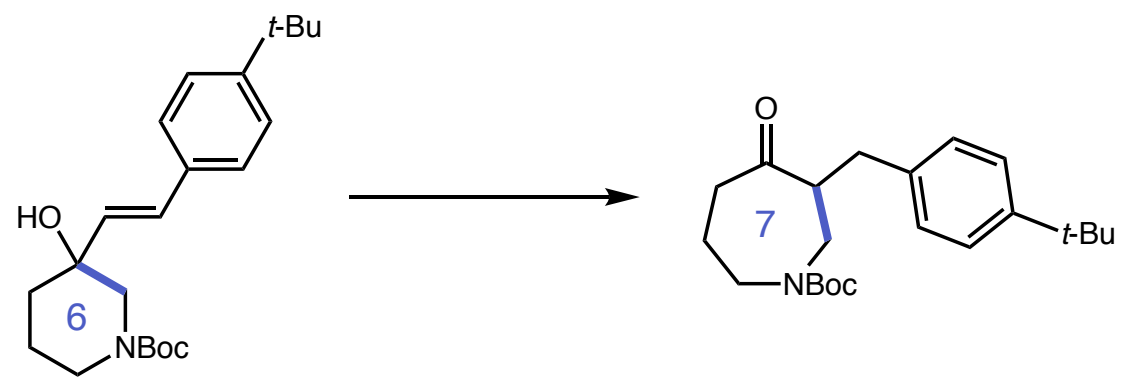

tert-Butyl 3-(4-(tert-butyl)benzyl)-4-oxoazepane-1-carboxylate (18a)

The titled compound was prepared on $0.5 \mathrm{mmol}$ scale following general procedure $\mathrm{B}$ with tertbutyl (E)-3-(4-(tert-butyl)styryl)-3-hydroxypiperidine-1-carboxylate (18) using PhMe (10 mL) solvent, TFA base $(25 \mathrm{~mol} \%)$, and TRIP-SH $(5 \mathrm{~mol} \%)$, and irradiated for $\underline{6 \mathrm{~d}}$ at $85^{\circ} \mathrm{C}$ (without fan). The crude material was purified by silica gel column chromatography ( $2 \%$ to $14 \%$ EtOAc in hexanes) to afford the titled compound as a pale yellow oil (126 mg, 70\%). ${ }^{1} \mathbf{H}$ NMR (400 MHz, DMSO-d $\left.{ }_{6}, 1^{\circ}{ }^{\circ} \mathbf{C}\right) \delta 7.30(\mathrm{~d}, J=8.2 \mathrm{~Hz}, 2 \mathrm{H}), 7.12(\mathrm{~d}, J=8.2 \mathrm{~Hz}, 2 \mathrm{H}), 3.81(\mathrm{dt}, J=14.0,4.7 \mathrm{~Hz}$, $1 \mathrm{H}), 3.72$ (dd, $J=14.0,5.3 \mathrm{~Hz}, 1 \mathrm{H}), 3.13-3.06(\mathrm{~m}, 2 \mathrm{H}), 3.02-2.89$ (m, 2H), 2.70-2.58 (m, 2H), $2.43(\mathrm{~m}, 1 \mathrm{H}), 1.81-1.64(\mathrm{~m}, 2 \mathrm{H}), 1.35(\mathrm{~s}, 9 \mathrm{H}), 1.29$ (s, 9H). ${ }^{13}$ C NMR (101 MHz, DMSO-d , $\left.\mathbf{1 2 0}^{\circ} \mathbf{C}\right) \delta 210.93,153.31,147.99,135.36,127.71,124.22,78.30,53.07,47.14,46.81,40.01,33.88$, 33.33, 30.46, 27.37, 24.01. IR (neat): 2962, 1689, 1465, 1412, 1241, 1159, 922, 770, $572 \mathrm{~cm}^{-1}$. HRMS (ESI): exact mass calculated for $[\mathrm{M}+\mathrm{H}]^{+}\left(\mathrm{C}_{22} \mathrm{H}_{34} \mathrm{NO}_{3}\right)$ requires $\mathrm{m} / \mathrm{z} 360.25332$, found $\mathrm{m} / \mathrm{z}$ 360.25320 .

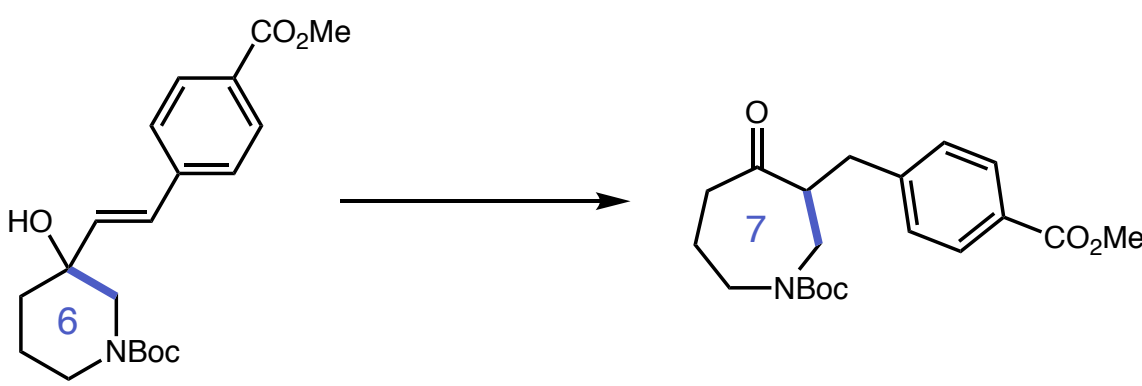

tert-Butyl 3-(4-(methoxycarbonyl)benzyl)-4-oxoazepane-1-carboxylate (19a)

The titled compound was prepared on $0.5 \mathrm{mmol}$ scale following general procedure B with tertbutyl (E)-3-hydroxy-3-(4-(methoxycarbonyl)styryl)piperidine-1-carboxylate (19) using $\mathrm{PhMe} \mathrm{(10}$ $\underline{\mathrm{mL}}$ ) solvent, TFA base (25 mol\%), and TRIP-SH (5 mol\%), and irradiated for $\underline{6 \mathrm{~d}}$ at $85^{\circ} \mathrm{C}$ (without fan). The crude material was purified by silica gel column chromatography ( $4 \%$ to $27 \%$ EtOAc in hexanes) to afford the titled compound as a pale yellow oil $(95.8 \mathrm{mg}, 53 \%){ }^{1} \mathbf{H}$ NMR (400 $\mathbf{~ M H z}$, DMSO- $\left.\boldsymbol{d}_{6}, \mathbf{1 2 0}^{\circ} \mathbf{C}\right) \delta 7.87(\mathrm{~d}, J=8.3 \mathrm{~Hz}, 2 \mathrm{H}), 7.34(\mathrm{~d}, J=8.3 \mathrm{~Hz}, 2 \mathrm{H}), 3.86(\mathrm{~s}, 3 \mathrm{H}), 3.77(\mathrm{dt}, J=$ 14.1, $4.9 \mathrm{~Hz}, 1 \mathrm{H}), 3.71(\mathrm{dd}, J=14.1,4.9 \mathrm{~Hz}, 1 \mathrm{H}), 3.19-3.00(\mathrm{~m}, 4 \mathrm{H}), 2.76(\mathrm{~m}, 1 \mathrm{H}), 2.65(\mathrm{~m}, 1 \mathrm{H})$, $2.45(\mathrm{~m}, 1 \mathrm{H}), 1.78-1.65(\mathrm{~m}, 2 \mathrm{H}), 1.36(\mathrm{~s}, 9 \mathrm{H}) .{ }^{\mathbf{1 3}} \mathbf{C}$ NMR $\left(\mathbf{1 0 1} \mathbf{M H z}\right.$, DMSO-d $\left.\boldsymbol{~}^{120}{ }^{\circ} \mathrm{C}\right) \delta 210.54$, 165.54, 153.36, 144.36, 128.47, 128.36, 127.48, 78.45, 52.69, 50.95, 47.18, 46.65, 40.06, 34.28, 27.38, 23.97. IR (neat): 2950, 1687, 1610, 1467, 1412, 1274, 1159, 1103, 920, 765, $528 \mathrm{~cm}^{-1}$. HRMS (ESI): exact mass calculated for $[\mathrm{M}+\mathrm{Na}]^{+}\left(\mathrm{C}_{20} \mathrm{H}_{27} \mathrm{NNaO}_{5}\right)$ requires $\mathrm{m} / z 384.17814$, found $m / z 384.17777$. 


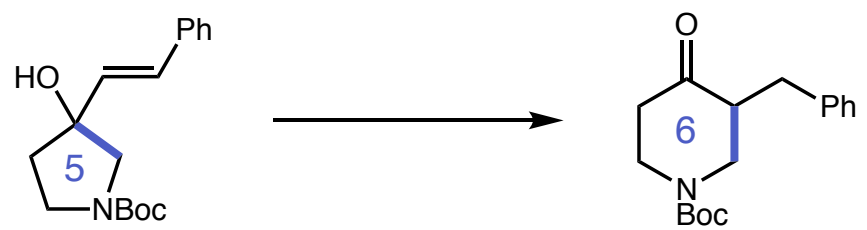

tert-Butyl 3-benzyl-4-oxopiperidine-1-carboxylate (20a)

The titled compound was prepared on $0.5 \mathrm{mmol}$ scale following general procedure B with tertbutyl (E)-3-hydroxy-3-styrylpyrrolidine-1-carboxylate (20) using $\mathrm{PhCF}_{3}(10 \mathrm{~mL})$ solvent, collidine base (3 equiv.), and TRIP-SH (20 mol\%), and irradiated for $\underline{6 \mathrm{~d}}$ at $35^{\circ} \mathrm{C}$ (with a fan to cool the reaction setup). The crude material was purified by silica gel column chromatography ( $2 \%$ to $18 \%$ EtOAc in hexanes) to afford the titled compound as a pale yellow solid (101 $\mathrm{mg}$, 70\%). ${ }^{1}$ H NMR (400 MHz, DMSO-d , $\left.^{120}{ }^{\circ} \mathbf{C}\right) \delta$ 7.31-7.27 (m, 2H), 7.22-7.18 (m, 3H), 3.97$3.87(\mathrm{~m}, 2 \mathrm{H}), 3.39(\mathrm{~m}, 1 \mathrm{H}), 3.13-3.04(\mathrm{~m}, 2 \mathrm{H}), 2.75(\mathrm{~m}, 1 \mathrm{H}), 2.54-2.46(\mathrm{~m}, 2 \mathrm{H}), 2.40(\mathrm{dt}, J=$ $14.9,5.0 \mathrm{~Hz}, 1 \mathrm{H}), 1.40$ (s, 9H). ${ }^{\mathbf{1 3}} \mathbf{C}$ NMR (101 MHz, DMSO-d $\left.\boldsymbol{d}_{\mathbf{1 2 0}}{ }^{\circ} \mathbf{C}\right) \delta 207.06,153.34,138.59$, 128.04, 127.52, 125.31, 78.69, 49.96, 46.47, 42.35, 39.32, 32.04, 27.40. IR (neat): 2977, 1683, 1496, 1415, 1238, 1157, 977, 855, 737, $550 \mathrm{~cm}^{-1}$. HRMS (ESI): exact mass calculated for [M+H] ${ }^{+}$ $\left(\mathrm{C}_{17} \mathrm{H}_{24} \mathrm{NO}_{3}\right)$ requires $m / z 290.17507$, found $m / z 290.17532$.

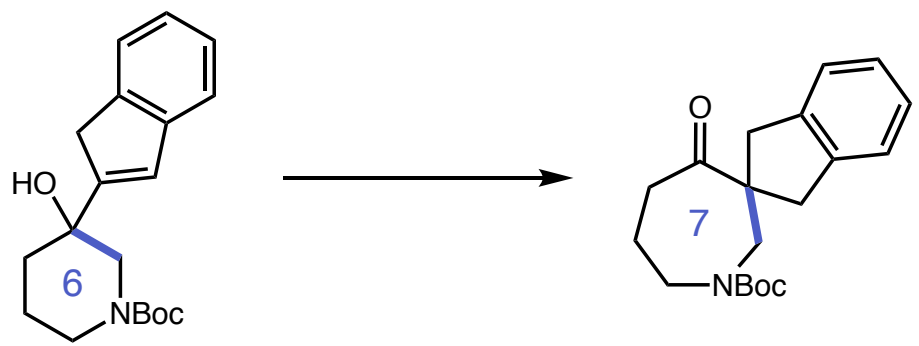

tert-Butyl 4-oxo-1',3'-dihydrospiro[azepane-3,2'-indene]-1-carboxylate (21a)

The titled compound was prepared on $0.5 \mathrm{mmol}$ scale following general procedure B with tertbutyl 3-hydroxy-3-(1H-inden-2-yl)piperidine-1-carboxylate (21) using $\underline{\mathrm{PhCF}}_{3}(10 \mathrm{~mL})$ solvent,

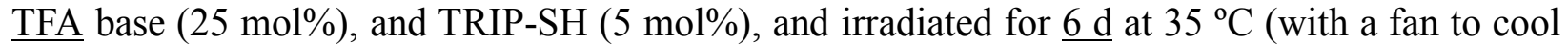
the reaction setup). The crude material was purified by silica gel column chromatography ( $2 \%$ to $15 \%$ EtOAc in hexanes) to afford the titled compound as an inseparable mixture of the desired product and $\sim 4 \%$ ring opened acyclic byproduct as judged by ${ }^{1} \mathrm{H}$ NMR analysis. This mixture is then purified by preparative SFC on a Chiralpak IC column $(2 \times 25 \mathrm{~cm}$, conditions: $70 \mathrm{~mL} / \mathrm{min}$, $15 \%$ methanol, $220 \mathrm{~nm}, 1 \mathrm{~mL} /$ injection) to afford the titled compound as a white solid (120 mg, 76\%). ${ }^{1}$ H NMR (400 MHz, DMSO-d $\left.{ }_{6}, 120^{\circ} \mathrm{C}\right) \delta 7.27-7.15(\mathrm{~m}, 4 \mathrm{H}), 4.10(\mathrm{ddd}, J=11.6,7.7,4.3$ $\mathrm{Hz}, 1 \mathrm{H}), 3.54-3.41(\mathrm{~m}, 3 \mathrm{H}), 3.31(\mathrm{dd}, J=16.2,10.2 \mathrm{~Hz}, 1 \mathrm{H}), 3.12(\mathrm{~m}, 1 \mathrm{H}), 2.97$ (dd, $J=14.4$, $11.4 \mathrm{~Hz}, 1 \mathrm{H}), 2.81(\mathrm{dd}, J=16.2,7.7 \mathrm{~Hz}, 1 \mathrm{H}), 2.70(\mathrm{dt}, J=13.5,7.7 \mathrm{~Hz}, 1 \mathrm{H}), 2.30(\mathrm{dt}, J=13.5$, $5.3 \mathrm{~Hz}, 1 \mathrm{H}), 2.08-2.00(\mathrm{~m}, 2 \mathrm{H}), 1.46(\mathrm{~s}, 9 \mathrm{H}) .{ }^{13} \mathbf{C}$ NMR (101 MHz, DMSO-d $\left.6, \mathbf{1 2 0}^{\circ} \mathrm{C}\right) \delta 210.88$, $153.73,142.99,141.15,126.42,125.74,124.05,122.84,78.45,55.05,50.60,47.54,46.68,37.33$, 30.06, 27.57, 25.13. IR (neat): 2971, 2930, 1686, 1477, 1406, 1364, 1226, 1157, 888, $749 \mathrm{~cm}^{-1}$. HRMS (ESI): exact mass calculated for $[\mathrm{M}+\mathrm{H}]^{+}\left(\mathrm{C}_{19} \mathrm{H}_{26} \mathrm{NO}_{3}\right)$ requires $\mathrm{m} / \mathrm{z} 316.19072$, found $\mathrm{m} / \mathrm{z}$ 316.19058 . 


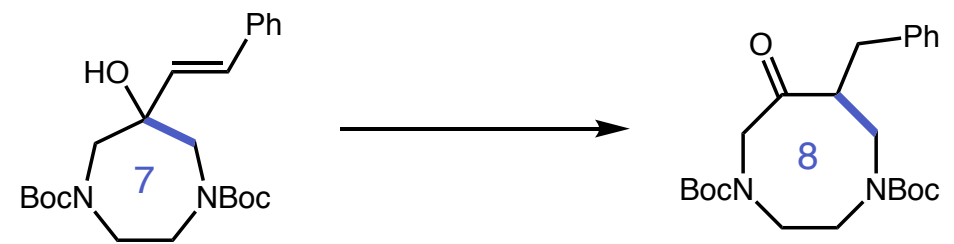

Di-tert-butyl 6-benzyl-7-oxo-1,4-diazocane-1,4-dicarboxylate (22a)

The titled compound was prepared on $0.5 \mathrm{mmol}$ scale following general procedure B with di-tertbutyl (E)-6-hydroxy-6-styryl-1,4-diazepane-1,4-dicarboxylate (22) using PhMe (10 mL) solvent, TFA base $(25 \mathrm{~mol} \%)$, and TRIP-SH $(5 \mathrm{~mol} \%)$, and irradiated for $7 \mathrm{~d}$ at $85^{\circ} \mathrm{C}$ (without fan). The crude material was purified by silica gel column chromatography ( $2 \%$ to $18 \%$ EtOAc in hexanes) to afford the titled compound as a pale yellow solid (172 $\mathrm{mg}, 82 \%)$. ${ }^{1}$ H NMR (400 MHz, DMSO$\left.\boldsymbol{d}_{6}, \mathbf{1 2 0}^{\circ} \mathbf{C}\right) \delta 7.27-7.23(\mathrm{~m}, 2 \mathrm{H}), 7.18-7.15(\mathrm{~m}, 3 \mathrm{H}), 4.21(\mathrm{~d}, J=18.3 \mathrm{~Hz}, 1 \mathrm{H}), 4.10(\mathrm{dt}, J=13.9$, $4.6 \mathrm{~Hz}, 1 \mathrm{H}), 3.49$ (dd, $J=12.9,4.9 \mathrm{~Hz}, 1 \mathrm{H}), 3.42$ (d, $J=10.6 \mathrm{~Hz}, 1 \mathrm{H}), 3.39-3.28$ (m, 4H), 3.01$2.93(\mathrm{~m}, 2 \mathrm{H}), 2.57(\mathrm{dd}, J=14.1,5.4 \mathrm{~Hz}, 1 \mathrm{H}), 1.40(\mathrm{~s}, 9 \mathrm{H}), 1.36(\mathrm{~s}, 9 \mathrm{H}) .{ }^{13} \mathbf{C}$ NMR (101 MHz, DMSO- $\left.\boldsymbol{d}_{\mathbf{6}} \mathbf{1 2 0}^{\circ} \mathbf{C}\right) \delta 211.86,153.89,153.19,138.72,128.00,127.49,125.30,79.37,78.90,57.70$, 50.73, 47.51, 46.94, 46.03, 33.50, 27.36, 27.24. IR (neat): 2974, 1688, 1453, 1413, 1236, 1150, 1041, 953, 770, $699 \mathrm{~cm}^{-1}$. HRMS (ESI): exact mass calculated for $\left[\mathrm{M}+\mathrm{Na}^{+}\left(\mathrm{C}_{23} \mathrm{H}_{34} \mathrm{~N}_{2} \mathrm{NaO}_{5}\right)\right.$ requires $\mathrm{m} / \mathrm{z} 441.23599$, found $\mathrm{m} / \mathrm{z} 441.23572$.
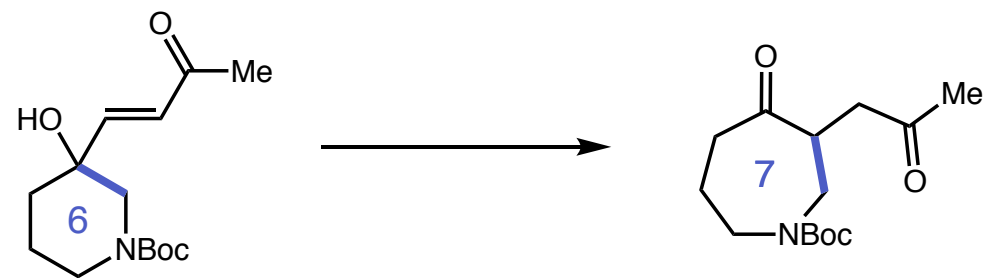

tert-Butyl 4-oxo-3-(pyridin-2-ylmethyl)azepane-1-carboxylate (23a)

The titled compound was prepared on $0.5 \mathrm{mmol}$ scale following general procedure B with tertbutyl (E)-3-hydroxy-3-(3-oxobut-1-en-1-yl)piperidine-1-carboxylate (23) using $\mathrm{PhCF}_{3}$ (10 mL) solvent and TFA base $\left(25 \mathrm{~mol} \%\right.$ ), and irradiated for $3 \mathrm{~d}$ at $35^{\circ} \mathrm{C}$ (with a fan to cool the reaction setup). The crude material was purified by silica gel column chromatography ( $7 \%$ to $60 \%$ EtOAc in hexanes) to afford the titled compound as a pale yellow oil $(88.5 \mathrm{mg}, 66 \%)$. ${ }^{\mathbf{1}} \mathbf{H}$ NMR (400 MHz, DMSO- $d_{6}$, mixture of rotamers) $\delta 3.14-2.88(\mathrm{~m}, 2 \mathrm{H}), 2.88-2.67(\mathrm{~m}, 2 \mathrm{H}), 2.25(\mathrm{dd}, J=$ $17.8,6.8 \mathrm{~Hz}, 1 \mathrm{H}), 2.14-1.91(\mathrm{~m}, 3 \mathrm{H}), 1.60-1.49(\mathrm{~m}, 4 \mathrm{H}), 1.22-1.00(\mathrm{~m}, 2 \mathrm{H}), 0.84$ (d, $J=3.8 \mathrm{~Hz}$, 9H) ${ }^{13} \mathbf{C}$ NMR (101 MHz, DMSO- $\boldsymbol{d}_{\mathbf{6}}$, mixture of rotamers) $\delta 211.82,206.54,206.28,154.24$, 153.88, 79.03, 78.93, 48.19, 48.07, 47.67, 47.50, 46.89, 46.31, 42.86, 42.83, 41.25, 41.08, 29.72, 27.96, 24.73, 24.68. IR (neat): 3419, 2975, 2932, 2861, 1667, 1627, 1432, 1391, 1151, 980, 765 $\mathrm{cm}^{-1}$. HRMS (ESI): exact mass calculated for $[\mathrm{M}+\mathrm{H}]^{+}\left(\mathrm{C}_{14} \mathrm{H}_{24} \mathrm{NO}_{4}\right)$ requires $m / z 270.16998$, found $m / z 270.16961$. 

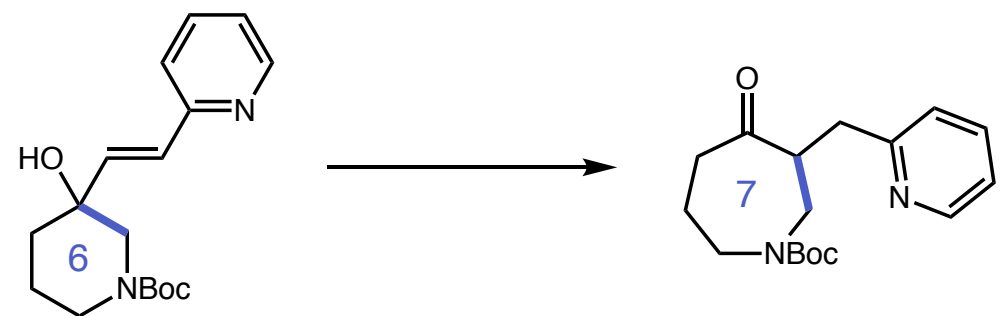

tert-Butyl 4-oxo-3-(pyridin-2-ylmethyl)azepane-1-carboxylate (24a)

The titled compound was prepared on $0.5 \mathrm{mmol}$ scale following general procedure $\mathrm{B}$ with tertbutyl (E)-3-hydroxy-3-(2-(pyridin-2-yl)vinyl)piperidine-1-carboxylate (24) using $\mathrm{PhCF}_{3}(10 \mathrm{~mL})$ solvent and TFA base $\left(25 \mathrm{~mol} \%\right.$ ), and irradiated for $\underline{6 \mathrm{~d}}$ at $35^{\circ} \mathrm{C}$ (with a fan to cool the reaction setup). The crude material was purified by silica gel column chromatography (20\% to $80 \%$ EtOAc in hexanes) to afford the titled compound as a pale yellow oil (117 mg, 77\%). ${ }^{1} \mathbf{H}$ NMR (400 MHz, DMSO-d $\left.{ }_{6}, 120^{\circ} \mathrm{C}\right) \delta 8.46(\mathrm{ddd}, J=4.9,1.9,1.0 \mathrm{~Hz}, 1 \mathrm{H}), 7.66(\mathrm{td}, J=7.7,1.9 \mathrm{~Hz}, 1 \mathrm{H}), 7.23(\mathrm{~d}$, $J=7.8 \mathrm{~Hz}, 1 \mathrm{H}), 7.17$ (dd, $J=7.5,4.8 \mathrm{~Hz}, 1 \mathrm{H}), 3.80-3.71(\mathrm{~m}, 2 \mathrm{H}), 3.34-3.03(\mathrm{~m}, 4 \mathrm{H}), 2.93-2.81$ (m, 1H), 2.69-2.55 (m, 1H), 2.55-2.39 (m, 1H), 1.79-1.68 (m, 2H), 1.37 (s, 9H). ${ }^{13}$ C NMR (101 MHz, DMSO-d $\mathbf{6}^{\left.\mathbf{1 2 0}^{\circ} \mathrm{C}\right)} \delta 210.75,158.35,153.43,148.16,135.44,122.45,120.51,78.34,51.24$, 47.12, 46.79, 40.26, 36.67, 27.41, 23.90. IR (neat): 2973, 2929,1685, 1435, 1142, 1244, 1154, 893, 751, $520 \mathrm{~cm}^{-1}$. HRMS (ESI): exact mass calculated for $[\mathrm{M}+\mathrm{H}]^{+}\left(\mathrm{C}_{17} \mathrm{H}_{25} \mathrm{~N}_{2} \mathrm{O}_{3}\right)$ requires $\mathrm{m} / z$ 305.18597, found $\mathrm{m} / \mathrm{z} 305.18596$.
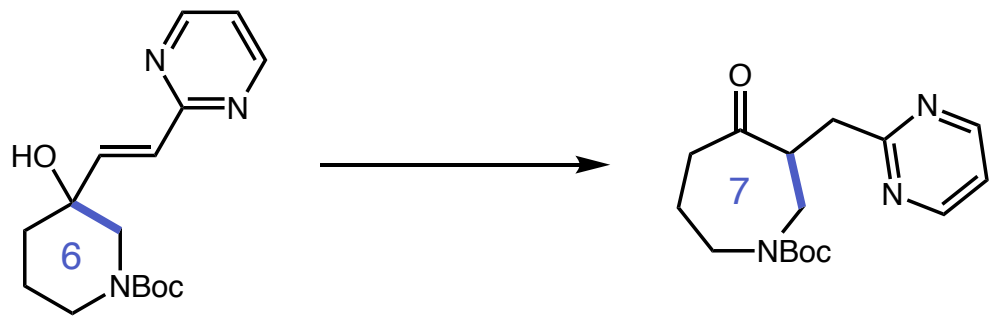

tert-Butyl 4-oxo-3-(pyridin-2-ylmethyl)azepane-1-carboxylate (25a)

The titled compound was prepared on $0.5 \mathrm{mmol}$ scale following general procedure B with $(E)$-tertbutyl 3-hydroxy-3-(pyrimidin-2-ylethynyl)piperidine-1-carboxylate (25) using $\mathrm{PhCF}_{3}(10 \mathrm{~mL})$ solvent and TFA base $\left(25 \mathrm{~mol} \%\right.$ ), and irradiated for $\underline{3 \mathrm{~d}}$ at $35^{\circ} \mathrm{C}$ (with a fan to cool the reaction setup). The crude material was purified by silica gel column chromatography ( $7 \%$ to $100 \%$ EtOAc in hexanes) to afford the titled compound as an inseparable mixture of the desired product and $\sim 8 \% \mathrm{n}+2$ ring expansion byproduct as judged by ${ }^{1} \mathrm{H}$ NMR analysis. This mixture is then purified by preparative SFC on a Lux Cellulose- 4 column $(2 \times 25 \mathrm{~cm}$, conditions: $70 \mathrm{~mL} / \mathrm{min}, 20 \%$ isopropanol, $220 \mathrm{~nm}, 1 \mathrm{~mL} /$ injection) to afford the title compound as a white solid. (122 mg, 80\%). ${ }^{1}$ H NMR (400 MHz, DMSO-d $\left.\mathbf{6} \mathbf{1 2 0}^{\circ} \mathrm{C}\right) \delta 8.67(\mathrm{~d}, J=4.9 \mathrm{~Hz}, 2 \mathrm{H}), 7.27(\mathrm{t}, J=4.9 \mathrm{~Hz}, 1 \mathrm{H}), 3.81-$ $3.66(\mathrm{~m}, 1 \mathrm{H}), 3.44-3.18(\mathrm{~m}, 4 \mathrm{H}), 3.01(\mathrm{dd}, J=15.3,6.9 \mathrm{~Hz}, 1 \mathrm{H}), 2.71-2.59(\mathrm{~m}, 1 \mathrm{H}), 2.58-2.49$ $(\mathrm{m}, 1 \mathrm{H}), 1.84-1.69(\mathrm{~m}, 1 \mathrm{H}), 1.38(\mathrm{~d}, J=1.0 \mathrm{~Hz}, 9 \mathrm{H}) .{ }^{13} \mathrm{C}$ NMR (101 MHz, DMSO-d $\left.\left.6, \mathbf{1 2 0}^{\circ} \mathrm{C}\right)\right)$ $\delta 210.42,167.72,156.19,153.46,118.17,78.38,50.24,47.05,46.69,40.39,37.93,27.42,23.74$. IR (neat): 3080, 2972, 2928, 2361, 2336, 1703, 1675, 1551, 1417, 1142, 921, $773 \mathrm{~cm}^{-1}$. HRMS (ESI): exact mass calculated for $[\mathrm{M}+\mathrm{H}]^{+}\left(\mathrm{C}_{16} \mathrm{H}_{24} \mathrm{~N}_{3} \mathrm{O}_{3}\right)$ requires $\mathrm{m} / \mathrm{z} 306.18122$, found $\mathrm{m} / \mathrm{z}$ 306.18143 . 


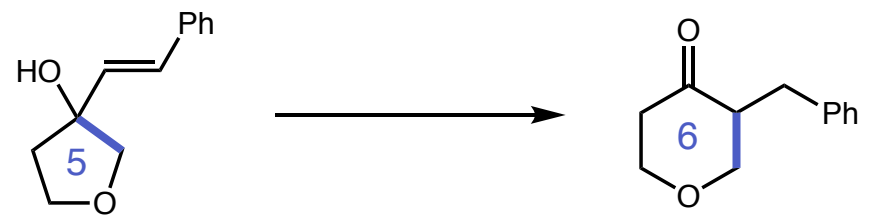

\section{3-Benzyltetrahydro-4H-pyran-4-one (26a)}

The titled compound was prepared on $0.5 \mathrm{mmol}$ scale following general procedure B with $(E)-3$ styryltetrahydrofuran-3-ol (26) using PhMe (10 mL) solvent, collidine base (3 equiv.), and TRIP$\mathrm{SH}(5 \mathrm{~mol} \%)$, and irradiated for $\underline{6 \mathrm{~d}}$ at $85^{\circ} \mathrm{C}$ (without fan). The crude material was purified by silica gel column chromatography (3\% to $23 \% \mathrm{Et}_{2} \mathrm{O}$ in hexanes) to afford the titled compound as a pale yellow oil (70.4 mg, 74\%). ${ }^{1} \mathbf{H}$ NMR (500 $\left.\mathbf{M H z}, \mathbf{C D C l}_{3}\right) \delta$ 7.29-7.26 (m, 2H), $7.20(\mathrm{~m}$, $1 \mathrm{H}), 7.16-7.15(\mathrm{~m}, 2 \mathrm{H}), 4.17(\mathrm{~m}, 1 \mathrm{H}), 4.03$ (ddd, $J=11.3,6.0,1.3 \mathrm{~Hz}, 1 \mathrm{H}), 3.75$ (td, $J=11.0,3.5$ $\mathrm{Hz}, 1 \mathrm{H}), 3.42(\mathrm{dd}, J=11.3,9.7 \mathrm{~Hz}, 1 \mathrm{H}), 3.21(\mathrm{dd}, J=14.3,5.1 \mathrm{~Hz}, 1 \mathrm{H}), 2.83(\mathrm{~m}, 1 \mathrm{H}), 2.62(\mathrm{~m}$, 1H), 2.49-2.44 (m, 2H). ${ }^{13} \mathbf{C}$ NMR (126 MHz, CDCl $) \delta 207.78,138.90,128.90$ (2C), 128.58 (2C), 126.41, 72.16, 68.73, 53.02, 42.52, 31.81. IR (neat): 2966, 2851, 1710, 1453, 1368, 1219, 1149, 1099, 972, 735, 698, $571 \mathrm{~cm}^{-1}$. HRMS (ESI): exact mass calculated for $[\mathrm{M}+\mathrm{H}]^{+}\left(\mathrm{C}_{12} \mathrm{H}_{15} \mathrm{O}_{2}\right)$ requires $m / z 191.10666$, found $m / z 191.10663$.
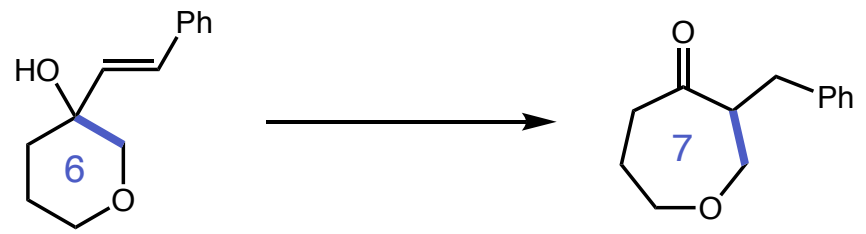

\section{3-Benzyloxepan-4-one (27a)}

The titled compound was prepared on $0.5 \mathrm{mmol}$ scale following general procedure B with $(E)-3$ styryltetrahydro-2 $\mathrm{H}$-pyran-3-ol (27) using $\underline{\mathrm{PhMe}(40 \mathrm{~mL})}$ solvent, $\underline{\mathrm{dPh}}$ base (25 mol\%), and TRIP$\mathrm{SH}\left(10 \mathrm{~mol} \%\right.$ ), and irradiated for $6 \mathrm{~d}$ at $85^{\circ} \mathrm{C}$ (without fan). The crude material was purified by silica gel column chromatography ( $3 \%$ to $23 \% \mathrm{Et}_{2} \mathrm{O}$ in hexanes) to afford the titled compound as a pale yellow oil (68.4 mg, 67\%). ${ }^{1} \mathbf{H}$ NMR (500 MHz, $\left.\mathbf{C D C l}_{3}\right) \delta$ 7.29-7.26 (m, 2H), 7.21-7.16 $(\mathrm{m}, 3 \mathrm{H}), 3.91(\mathrm{~m}, 1 \mathrm{H}), 3.84(\mathrm{dd}, J=13.0,4.0 \mathrm{~Hz}, 1 \mathrm{H}), 3.69(\mathrm{~m}, 1 \mathrm{H}), 3.54(\mathrm{dd}, J=13.0,7.6 \mathrm{~Hz}$, $1 \mathrm{H}), 3.11(\mathrm{dd}, J=13.9,5.1 \mathrm{~Hz}, 1 \mathrm{H}), 2.93(\mathrm{~m}, 1 \mathrm{H}), 2.70-2.58(\mathrm{~m}, 3 \mathrm{H}), 1.92-1.78(\mathrm{~m}, 2 \mathrm{H}) .{ }^{13} \mathbf{C}$ NMR (126 MHz, CDCl $\mathbf{C l}_{3} \delta$ 212.90, 139.08, 129.18 (2C), 128.63 (2C), 126.48, 73.11, 70.31, 56.00, 42.32, 34.46, 26.55. IR (neat): 2922, 2852, 1699, 1453, 1370, 1251, 1118, 1083, 933, 752, 699, $503 \mathrm{~cm}^{-1}$. HRMS (ESI): exact mass calculated for $[\mathrm{M}+\mathrm{H}]^{+}\left(\mathrm{C}_{13} \mathrm{H}_{17} \mathrm{O}_{2}\right)$ requires $\mathrm{m} / z$ 205.12231, found $\mathrm{m} / \mathrm{z} 205.12227$.
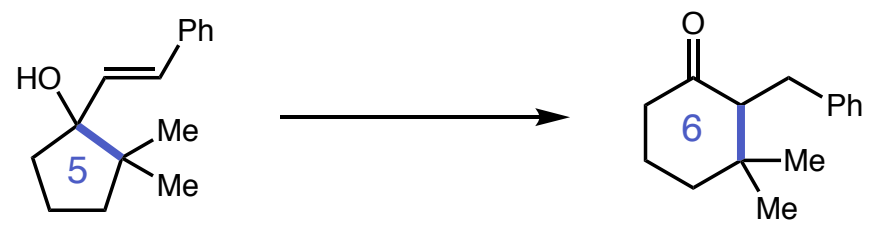

\section{2-Benzyl-3,3-dimethylcyclohexan-1-one (28a)}

The titled compound was prepared on $0.5 \mathrm{mmol}$ scale following general procedure B with $(E)-2,2-$ dimethyl-1-styrylcyclopentan-1-ol (28) using $\underline{\mathrm{PhMe}(10 \mathrm{~mL})}$ solvent, collidine base (3 equiv.), and 
benzenethiol (10 mol\%), and irradiated for $6 \mathrm{~d}$ at $85^{\circ} \mathrm{C}$ (without fan). The crude material was purified by silica gel column chromatography $\left(0 \%\right.$ to $5 \% \mathrm{Et}_{2} \mathrm{O}$ in hexanes) to afford the titled compound as a pale yellow solid (84.4 mg, 78\%). ${ }^{1} \mathbf{H}$ NMR (500 $\left.\mathbf{~ M H z}, \mathbf{C D C l}_{3}\right) \delta$ 7.26-7.20 (m, 4H), $7.14(\mathrm{~m}, 1 \mathrm{H}), 3.10(\mathrm{dd}, J=13.8,9.9 \mathrm{~Hz}, 1 \mathrm{H}), 2.58(\mathrm{dd}, J=13.8,2.2 \mathrm{~Hz}, 1 \mathrm{H}), 2.51(\mathrm{dd}, J=$ 9.9, $1.3 \mathrm{~Hz}, 1 \mathrm{H}), 2.33$ (dtd, $J=12.8,4.2,1.3 \mathrm{~Hz}, 1 \mathrm{H}), 2.23(\mathrm{~m}, 1 \mathrm{H}), 1.92(\mathrm{~m}, 1 \mathrm{H}), 1.83(\mathrm{~m}, 1 \mathrm{H})$, $1.72(\mathrm{td}, J=12.8,4.2 \mathrm{~Hz}, 1 \mathrm{H}), 1.63(\mathrm{~m}, 1 \mathrm{H}), 1.20$ (s, 3H), 0.85 (s, 3H). ${ }^{\mathbf{1 3}} \mathbf{C}$ NMR (126 MHz, $\left.\mathbf{C D C l}_{3}\right) \delta 212.11,142.22,129.13,128.33,125.77,63.46,41.92,40.57,40.09,30.07,29.63,23.44$, 21.47. IR (neat): 2940, 1707, 1454, 1370, 1166, 1077, 934, 737, 695, $498 \mathrm{~cm}^{-1}$. HRMS (ESI): exact mass calculated for $[\mathrm{M}+\mathrm{H}]^{+}\left(\mathrm{C}_{15} \mathrm{H}_{21} \mathrm{O}\right)$ requires $\mathrm{m} / \mathrm{z} 217.15869$, found $m / z 217.15865$.

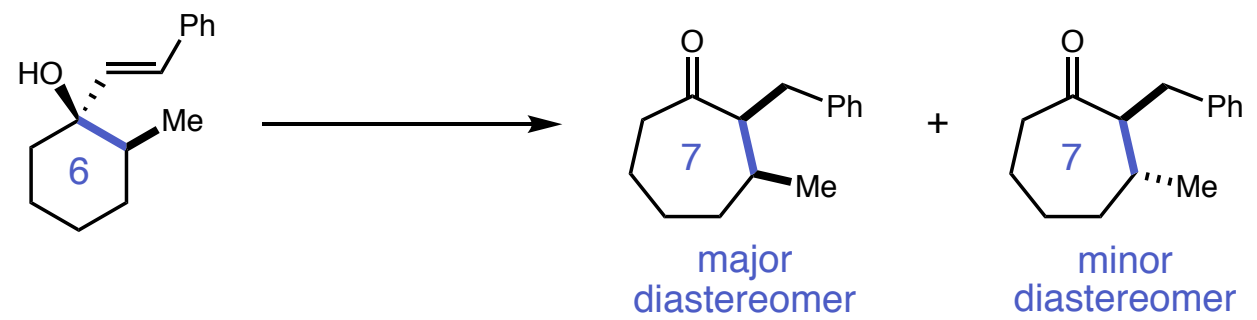

Prepared on $0.5 \mathrm{mmol}$ scale following the general procedure B with $\left(1 R^{*}, 2 S^{*}\right)-2$-methyl-1-((E)styryl)cyclohexan-1-ol (29) using PhMe (40 mL) solvent, $\underline{\mathrm{dPh}}$ base (25 mol\%), and TRIP-SH (20 $\mathrm{mol} \%$ ), and irradiated for $6 \mathrm{~d}$ at $85^{\circ} \mathrm{C}$ (without fan). The crude material was purified by silica gel column chromatography ( $\left(0 \%\right.$ to $3 \% \mathrm{Et}_{2} \mathrm{O}$ in hexanes) to afford a $1.7: 1$ mixture of diastereomers as a pale yellow oil $(75.7 \mathrm{mg}, 70 \%)$. The diastereomers were separated by preparative SFC on a Chiralpak AD-H column $(3 \times 25 \mathrm{~cm}$, conditions: $70 \mathrm{~mL} / \mathrm{min}, 10 \%$ methanol, $220 \mathrm{~nm}, 1$ $\mathrm{mL} /$ injection) and their stereochemistries were determined by NOESY analysis (see product NMR section).

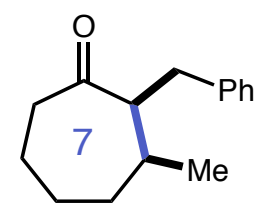

cis-2-Benzyl-3-methylcycloheptan-1-one (29a, major isomer)

${ }^{1}$ H NMR (500 MHz, CDCl $) \delta 7.29-7.26(\mathrm{~m}, 2 \mathrm{H}), 7.20-7.16(\mathrm{~m}, 3 \mathrm{H}), 3.18(\mathrm{td}, J=7.0,1.9 \mathrm{~Hz}$, $1 \mathrm{H}), 3.12$ (dd, $J=13.8,6.7 \mathrm{~Hz}, 1 \mathrm{H}), 2.59$ (dd, $J=13.8,7.5 \mathrm{~Hz}, 1 \mathrm{H}), 2.46(\mathrm{~m}, 1 \mathrm{H}), 2.32(\mathrm{~m}, 1 \mathrm{H})$, $1.99(\mathrm{~m}, 1 \mathrm{H}), 1.85(\mathrm{~m}, 1 \mathrm{H}), 1.79-1.63(\mathrm{~m}, 4 \mathrm{H}), 1.42(\mathrm{~m}, 1 \mathrm{H}), 0.84(\mathrm{~d}, J=7.3 \mathrm{~Hz}, 3 \mathrm{H}) .{ }^{13} \mathbf{C}$ NMR $\left(\mathbf{1 2 6} \mathbf{~ M H z}, \mathbf{C D C l}_{3}\right) \delta 214.38,140.97,129.14,128.43,126.04,56.82,44.52,37.60,35.25,32.61$, 23.92, 23.76, 14.07. IR (neat): 3026, 2926, 1695, 1452, 1382, 1235, 1185, 1070, 930, $697 \mathrm{~cm}^{-1}$. HRMS (ESI): exact mass calculated for $[\mathrm{M}+\mathrm{H}]^{+}\left(\mathrm{C}_{15} \mathrm{H}_{21} \mathrm{O}\right)$ requires $\mathrm{m} / z 217.15869$, found $\mathrm{m} / \mathrm{z}$ 217.15863 .

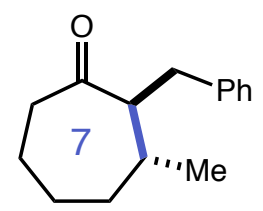

trans-2-Benzyl-3-methylcycloheptan-1-one (29a, minor isomer) 
${ }^{1}$ H NMR (500 MHz, CDCl $) \delta$ 7.26-7.23 (m, 2H), $7.17(\mathrm{~m}, 1 \mathrm{H}), 7.12-7.11(\mathrm{~m}, 2 \mathrm{H}), 2.96(\mathrm{dd}, J$ $=13.8,9.7 \mathrm{~Hz}, 1 \mathrm{H}), 2.86(\mathrm{dd}, J=13.8,4.3 \mathrm{~Hz}, 1 \mathrm{H}), 2.56(\mathrm{td}, J=9.3,4.3 \mathrm{~Hz}, 1 \mathrm{H}), 2.38(\mathrm{~m}, 1 \mathrm{H})$, $2.19(\mathrm{~m}, 1 \mathrm{H}), 1.84-1.75(\mathrm{~m}, 2 \mathrm{H}), 1.72-1.57(\mathrm{~m}, 3 \mathrm{H}), 1.41(\mathrm{~m}, 1 \mathrm{H}), 1.31(\mathrm{~m}, 1 \mathrm{H}), 1.10(\mathrm{~d}, J=6.8$ $\mathrm{Hz}, 3 \mathrm{H}) .{ }^{13} \mathbf{C}$ NMR (126 MHz, $\left.\mathbf{C D C l}_{3}\right) \delta 215.38,139.88,129.04,128.46,126.24,61.11,42.73$, 37.13, 36.09, 35.38, 26.88, 25.28, 21.22. IR (neat): 3026, 2926, 1695, 1452, 1382, 1235, 1185 , 1070, 930, $697 \mathrm{~cm}^{-1}$. HRMS (ESI): exact mass calculated for $[\mathrm{M}+\mathrm{H}]^{+}\left(\mathrm{C}_{15} \mathrm{H}_{21} \mathrm{O}\right)$ requires $\mathrm{m} / z$ 217.15869, found $m / z 217.15863$.
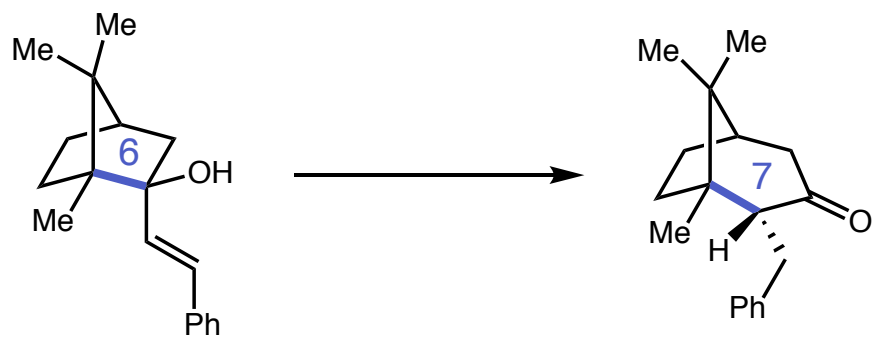

(1S,2R,5R)-2-Benzyl-1,8,8-trimethylbicyclo[3.2.1]octan-3-one (30a)

The titled compound was prepared on $0.5 \mathrm{mmol}$ scale following general procedure B with $(1 R, 2 S, 4 R)-1,7,7$-trimethyl-2-((E)-styryl)bicyclo[2.2.1] heptan-2-ol (30) using PhMe (40 mL) solvent, $\underline{\mathrm{dPh}}$ base $\left(25 \mathrm{~mol} \%\right.$ ), and TRIP-SH $(20 \mathrm{~mol} \%)$, and irradiated for $\underline{6 \mathrm{~d}}$ at $85^{\circ} \mathrm{C}$ (without fan). The crude material was purified by silica gel column chromatography $\left(0 \%\right.$ to $5 \% \mathrm{Et}_{2} \mathrm{O}$ in hexanes) to afford the titled compound as a pale yellow solid (98.7 $\mathrm{mg}, 77 \%)$. The absolute configuration was determined by NOESY analysis (see product NMR section). ${ }^{1} \mathbf{H}$ NMR (500 MHz, CDCl $\left.\mathbf{l}_{3}\right) \delta 7.29-7.25(\mathrm{~m}, 4 \mathrm{H}), 7.16(\mathrm{~m}, 1 \mathrm{H}), 3.33(\mathrm{dd}, J=14.4,6.5 \mathrm{~Hz}, 1 \mathrm{H}), 2.73(\mathrm{dt}, J=$ 15.8, $2.7 \mathrm{~Hz}, 1 \mathrm{H}), 2.67(\mathrm{~m}, 1 \mathrm{H}), 2.51$ (dd, $J=14.4,3.3 \mathrm{~Hz}, 1 \mathrm{H}), 2.24$ (dd, $J=15.8,2.7 \mathrm{~Hz}, 1 \mathrm{H})$, 2.03-1.94 (m, 2H), $1.71(\mathrm{~m}, 1 \mathrm{H}), 1.52(\mathrm{~m}, 1 \mathrm{H}), 1.36(\mathrm{~m}, 1 \mathrm{H}), 1.18(\mathrm{~s}, 3 \mathrm{H}), 1.03(\mathrm{~s}, 3 \mathrm{H}), 1.02(\mathrm{~s}$, $3 \mathrm{H}) .{ }^{13} \mathbf{C}$ NMR (126 MHz, $\left.\mathbf{C D C l}_{3}\right) \delta 212.19,143.46,128.97,128.28,125.50,59.45,49.91,46.92$, 45.86, 44.82, 31.13, 30.83, 27.48, 25.01, 19.22, 18.92. IR (neat): 2952, 1702, 1452, 1391, 1223 , 1120, 1029, 740, 697, $554 \mathrm{~cm}^{-1}$. HRMS (ESI): exact mass calculated for $[\mathrm{M}+\mathrm{H}]^{+}\left(\mathrm{C}_{18} \mathrm{H}_{25} \mathrm{O}\right)$ requires $m / z$ 257.18999, found $m / z 257.19009$.

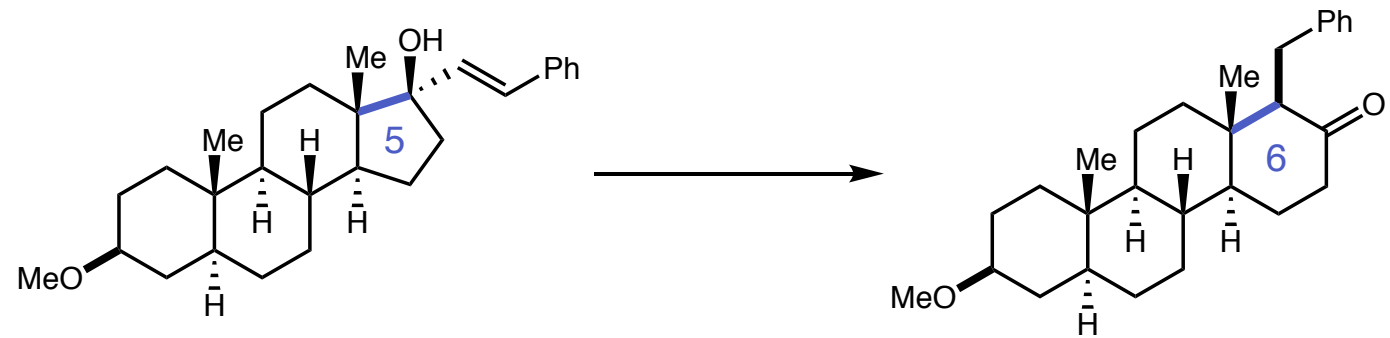

$(1 R, 4 \mathrm{a} S, 4 \mathrm{~b} R, 6 \mathrm{a} S, 8 S, 10 \mathrm{a} S, 10 \mathrm{~b} S, 12 \mathrm{a} S)-1-B e n z y l-8-m e t h o x y-10 \mathrm{a}, 12 \mathrm{a}-$ dimethylhexadecahydrochrysen-2(1H)-one (31a)

The titled compound was prepared on $0.5 \mathrm{mmol}$ scale following general procedure B with (3S,5S,8R,9S,10S,13S,14S,17R)-3-methoxy-10,13-dimethyl-17-((E)-styryl)hexadecahydro-1 $H$ cyclopenta[a]phenanthren-17-ol (31) using $\mathrm{PhMe}(10 \mathrm{~mL})$ solvent, collidine base (3 equiv.), and benzenethiol $\left(20 \mathrm{~mol} \%\right.$ ), and irradiated for $\underline{6 \mathrm{~d}}$ at $85^{\circ} \mathrm{C}$ (without fan). The crude material was purified by silica gel column chromatography (2\% to $10 \% \mathrm{Et}_{2} \mathrm{O}$ in hexanes) to afford the titled compound as a white solid (125 mg, 61\%). The absolute configuration was determined by X-ray 
crystallographic analysis (see Figure S5 for details). ${ }^{1} \mathbf{H}$ NMR (500 $\left.\mathbf{~ M H z , ~} \mathbf{C D C l}_{3}\right) \delta$ 7.23-7.18 (m, 4H), $7.12(\mathrm{~m}, 1 \mathrm{H}), 3.34(\mathrm{~s}, 3 \mathrm{H}), 3.17-3.08(\mathrm{~m}, 2 \mathrm{H}), 2.53(\mathrm{~d}, J=13.7 \mathrm{~Hz}, 1 \mathrm{H}), 2.43(\mathrm{~d}, J=8.9 \mathrm{~Hz}$, $1 \mathrm{H}), 2.34(\mathrm{~m}, 1 \mathrm{H}), 2.21(\mathrm{~m}, 1 \mathrm{H}), 2.13(\mathrm{~m}, 1 \mathrm{H}), 2.01(\mathrm{~m}, 1 \mathrm{H}), 1.92-1.89(\mathrm{~m}, 2 \mathrm{H}), 1.78(\mathrm{td}, J=13.1$, $3.5 \mathrm{~Hz}, 1 \mathrm{H}), 1.69-1.66(\mathrm{~m}, 2 \mathrm{H}), 1.42-1.17(\mathrm{~m}, 9 \mathrm{H}), 1.07(\mathrm{tt}, J=12.3,3.0 \mathrm{~Hz}, 1 \mathrm{H}), 0.98-0.83(\mathrm{~m}$, 2H), $0.78(\mathrm{~s}, 3 \mathrm{H}), 0.77(\mathrm{~m}, 1 \mathrm{H}), 0.72(\mathrm{~s}, 3 \mathrm{H}) .{ }^{13} \mathbf{C}$ NMR (126 MHz, CDCl 3$) \delta 211.52,142.77$, 129.17 (2C), 128.20 (2C), 125.54, 79.75, 65.07, 55.64, 53.69, 51.46, 44.19, 42.96, 42.06, 38.91, 36.83, 35.92, 35.76, 34.21, 31.41, 28.78, 27.86, 27.84, 26.70, 21.03, 13.73, 12.28. IR (neat): 2927, 2849, 1702, 1447, 1385, 1172, 1102, 742, 699, $498 \mathrm{~cm}^{-1}$. HRMS (ESI): exact mass calculated for $[\mathrm{M}+\mathrm{H}]^{+}\left(\mathrm{C}_{28} \mathrm{H}_{41} \mathrm{O}_{2}\right)$ requires $\mathrm{m} / z$ 409.31011, found $\mathrm{m} / \mathrm{z} 409.31003$.

Crystal data of 31a (Figure S9): Compound 31a was recrystallized from $n$-hexanesdichloromethane at room temperature in 2 days. Formula $\mathrm{C}_{28} \mathrm{H}_{40} \mathrm{O}_{2}$, colorless, crystal dimensions $0.32 \times 0.25 \times 0.20 \mathrm{~mm}^{3}$, triclinic, space group $P 1(\# 1), a=6.7263(5) \AA, b=9.6206(7) \AA, c=$ 10.0133(7) $\AA, \alpha=114.987(2)^{\mathrm{o}}, \beta=102.242(2)^{\mathrm{o}}, \gamma=94.169(2)^{\mathrm{o}}, V=564.26(7) \AA^{3}, Z=1, \rho_{\text {calc }}=$ $1.202 \mathrm{~g} \mathrm{~cm}^{-3}, \mathrm{~F}(000)=224, \mu(\mathrm{MoK} \alpha)=0.073 \mathrm{~mm}^{-1}, T=100 \mathrm{~K} .33508$ reflections collected, 10387 independent reflections with $I>2 \sigma(I)\left(2 \theta_{\max }=71.24^{\circ}\right)$, and 274 parameters were used for the solution of the structure. The non-hydrogen atoms were refined anisotropically. $R_{1}=0.0320$ and $w R_{2}=0.0876 . \mathrm{GOF}=1.028$. Flack x parameter $=-0.02(17)$. Crystallographic data (excluding structure factors) for the structure reported in this paper have been deposited with the Cambridge Crystallographic Data Centre as supplementary publication no. CCDC-1900668. Copies of the data can be obtained free of charge on application to CCDC, 12 Union Road, Cambridge CB2 1EZ, UK [Web page: http://www.ccdc.cam.ac.uk/].

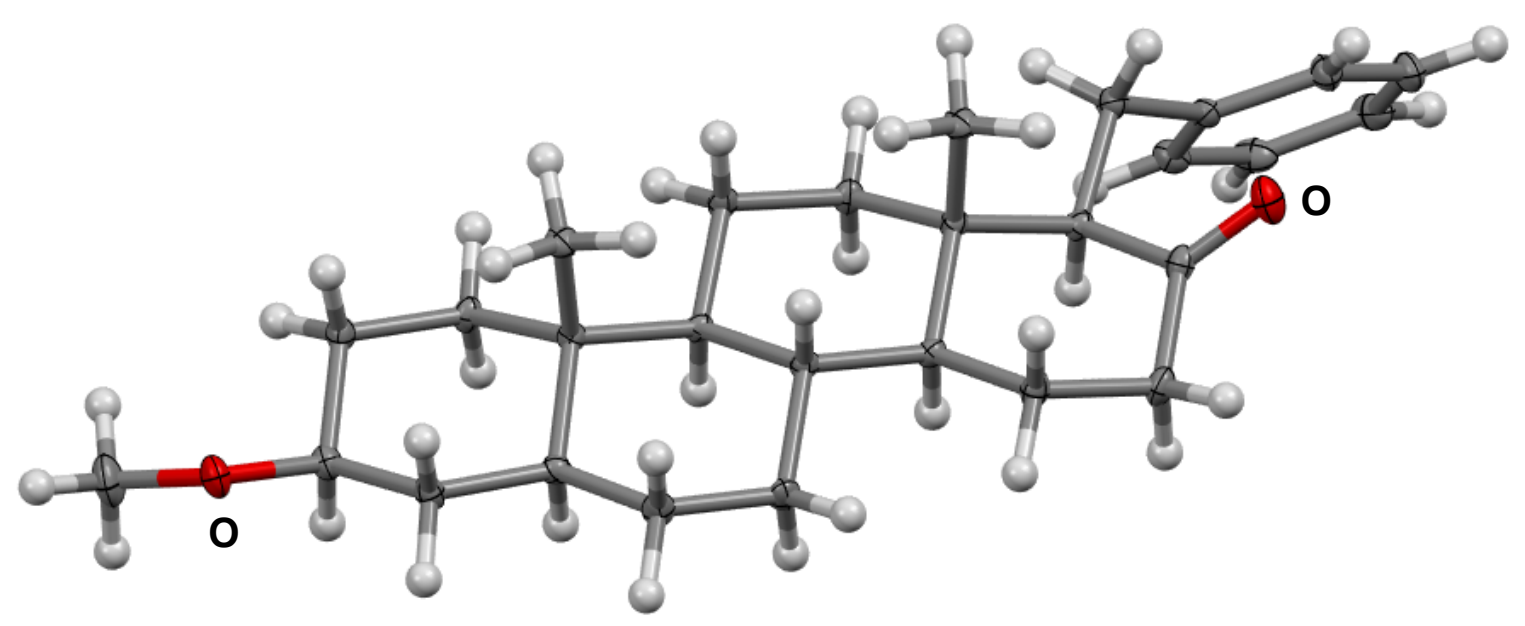

Figure S9. ORTEP drawing of 31a 
${ }^{1} \mathrm{H}$ and ${ }^{13} \mathrm{C}$ NMR Spectra of Products
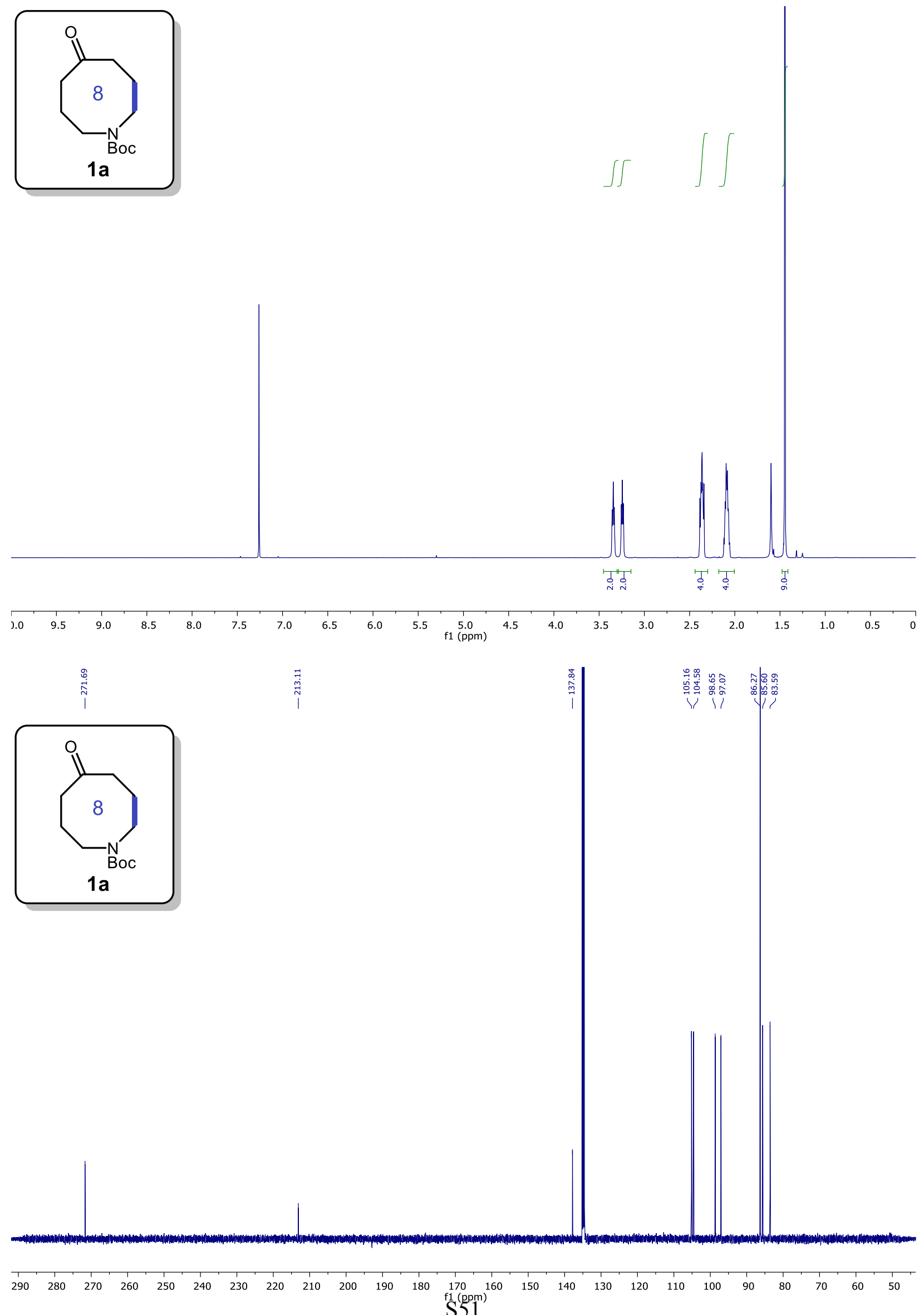

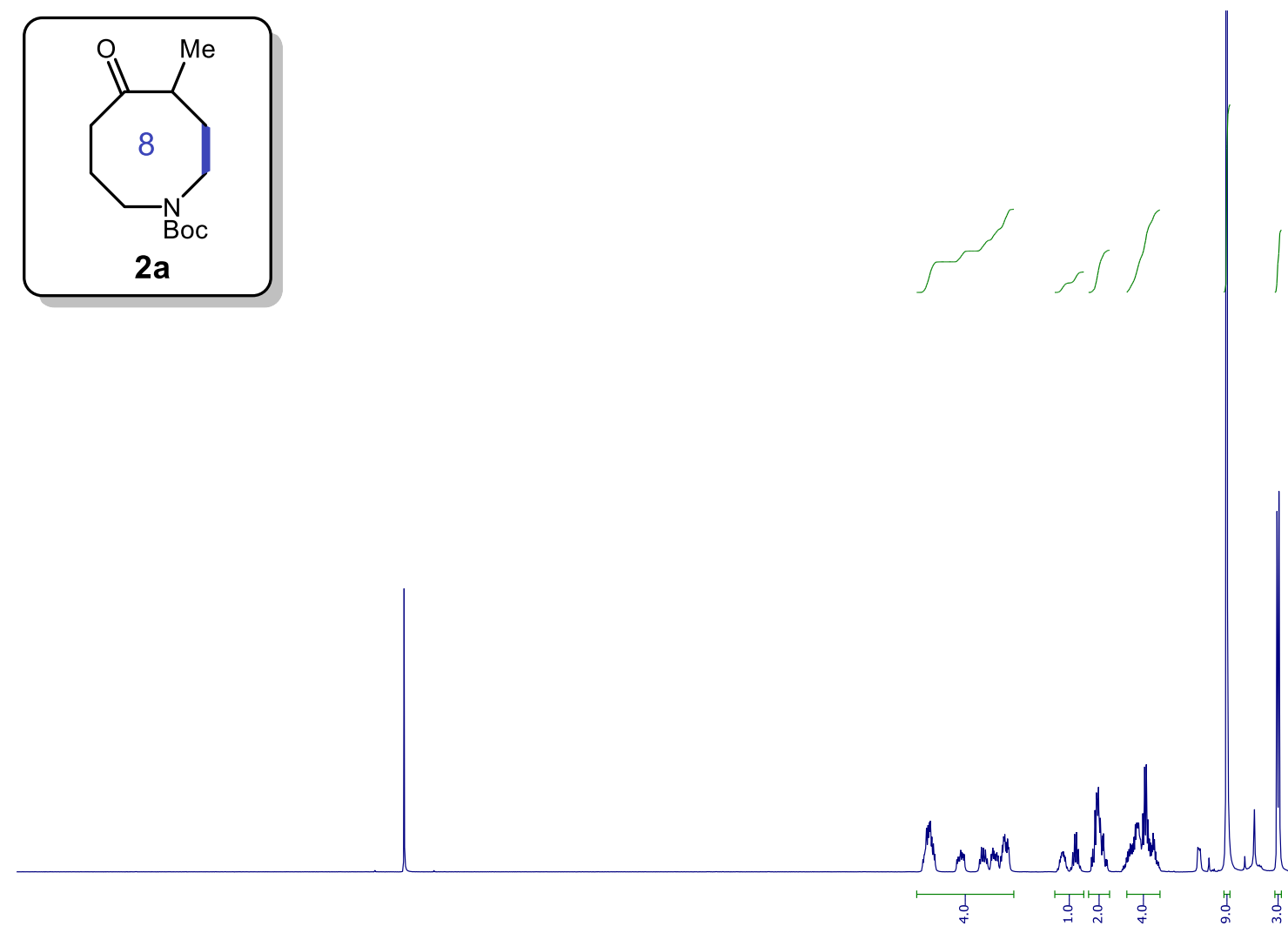

\begin{tabular}{|c|c|c|c|c|c|c|c|c|c|c|c|c|c|c|c|c|c|c|c|}
\hline 3.0 & 9.5 & 9.0 & 8.5 & 8.0 & 7.5 & 7.0 & 6.5 & 6.0 & 5.5 & $\begin{array}{c}5.0 \\
\text { f1 (ppm) }\end{array}$ & 4.5 & 4.0 & 3.5 & 3.0 & 2.5 & 2.0 & 1.5 & 1.0 & 0.5 \\
\hline
\end{tabular}

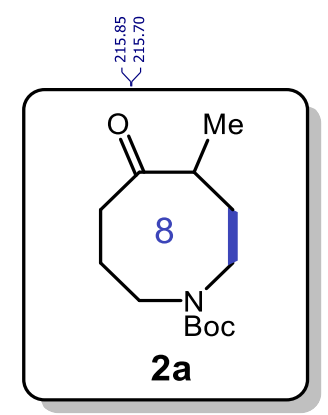

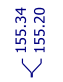

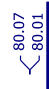

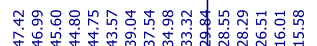
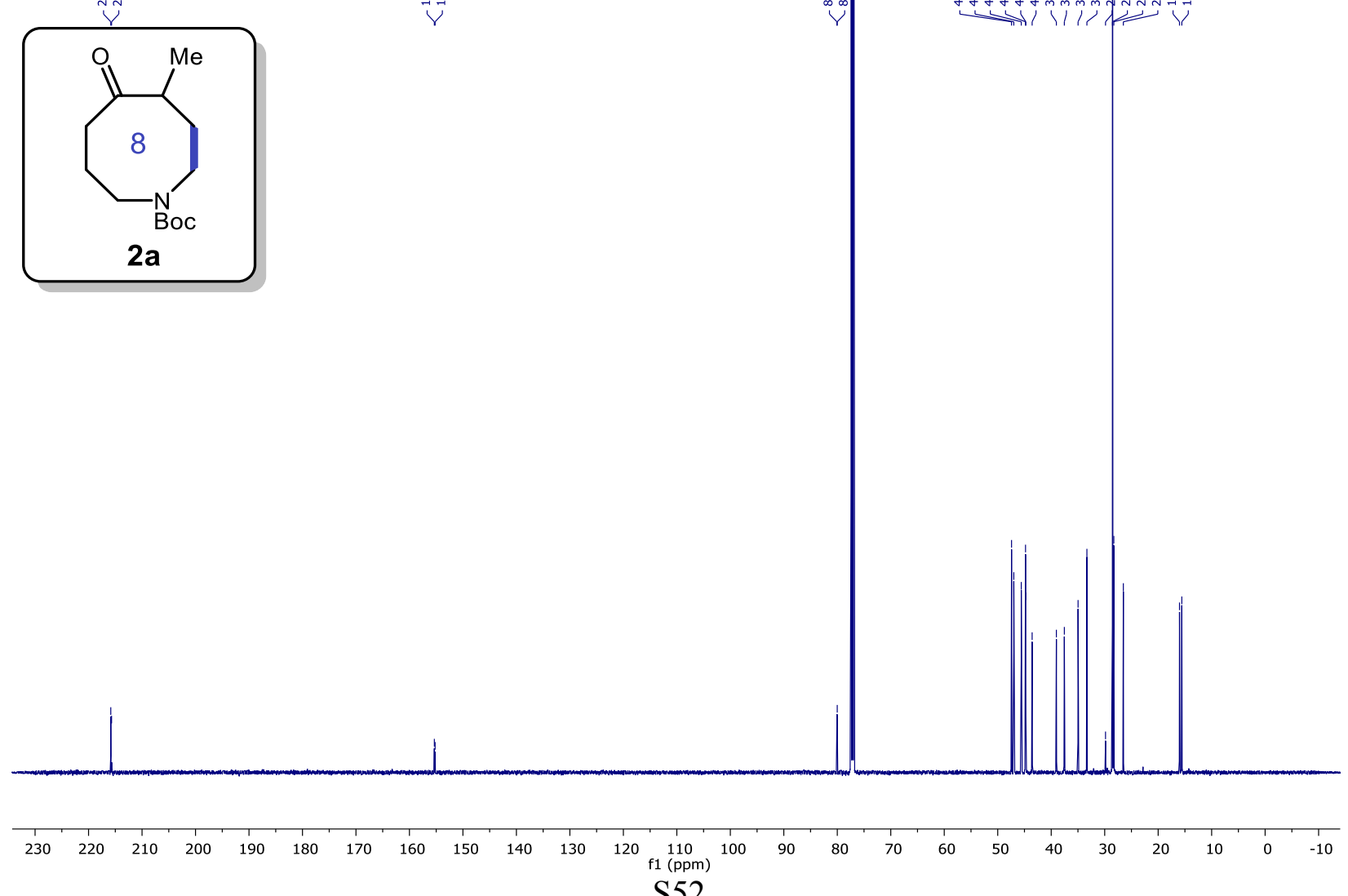

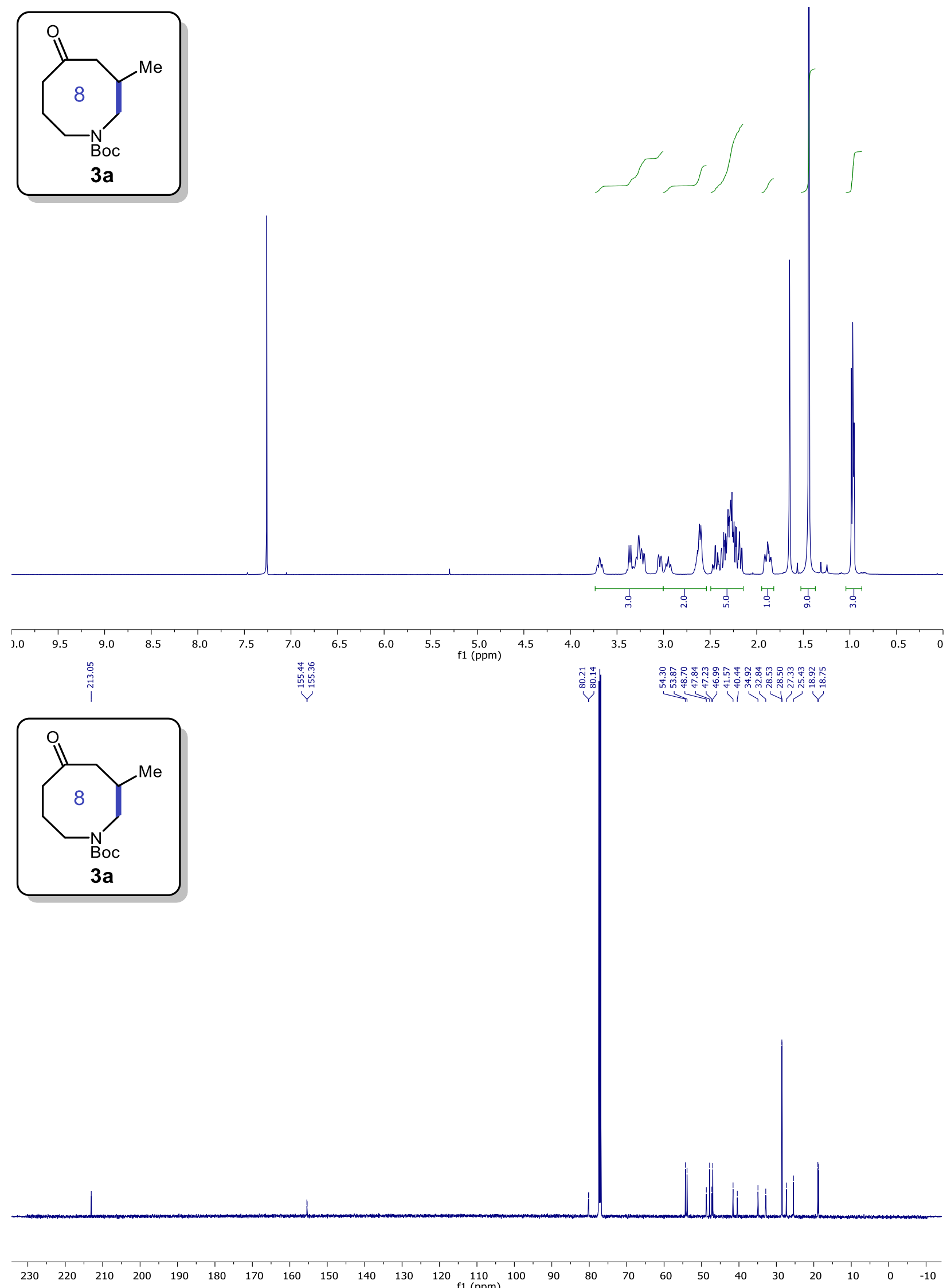

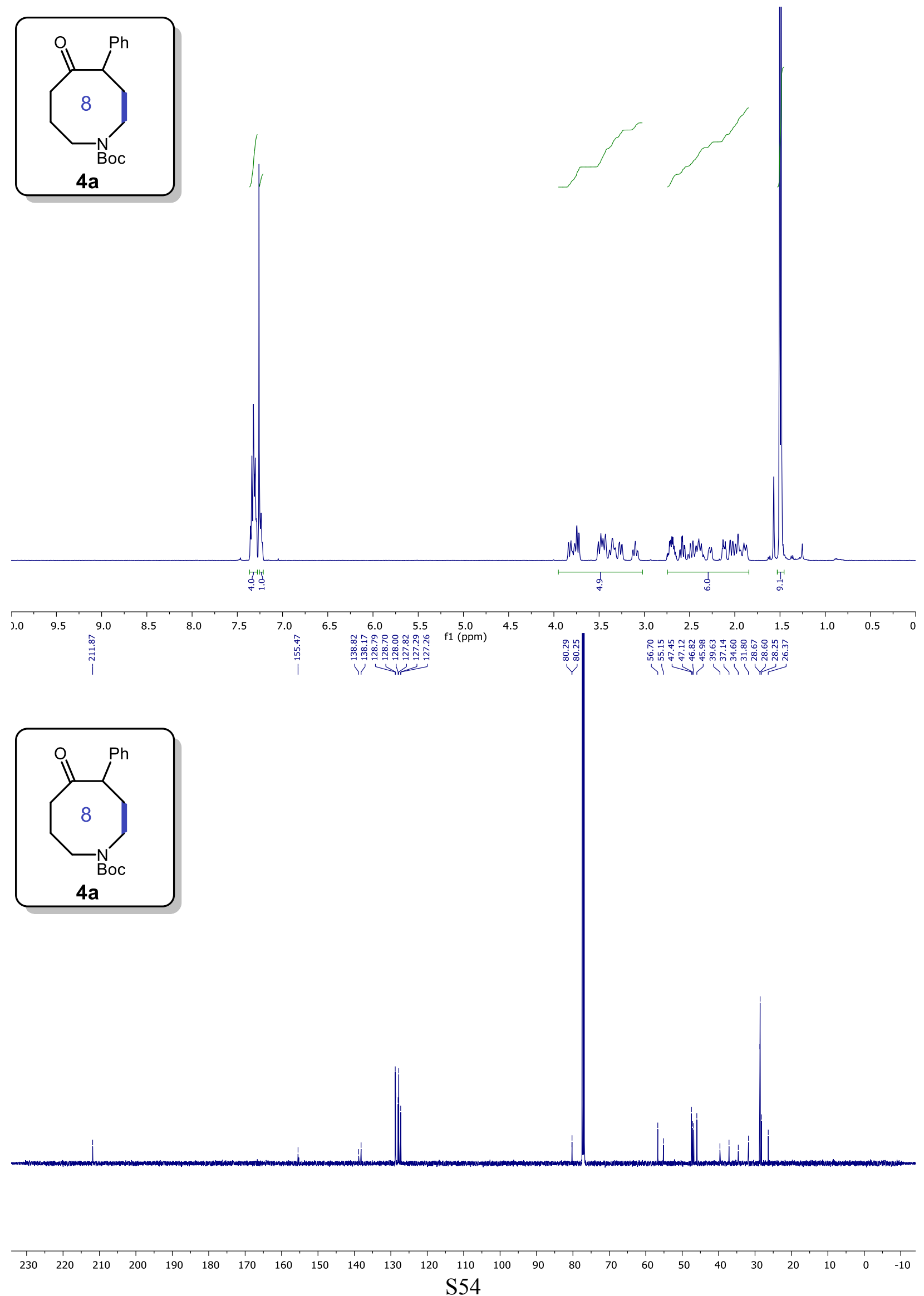

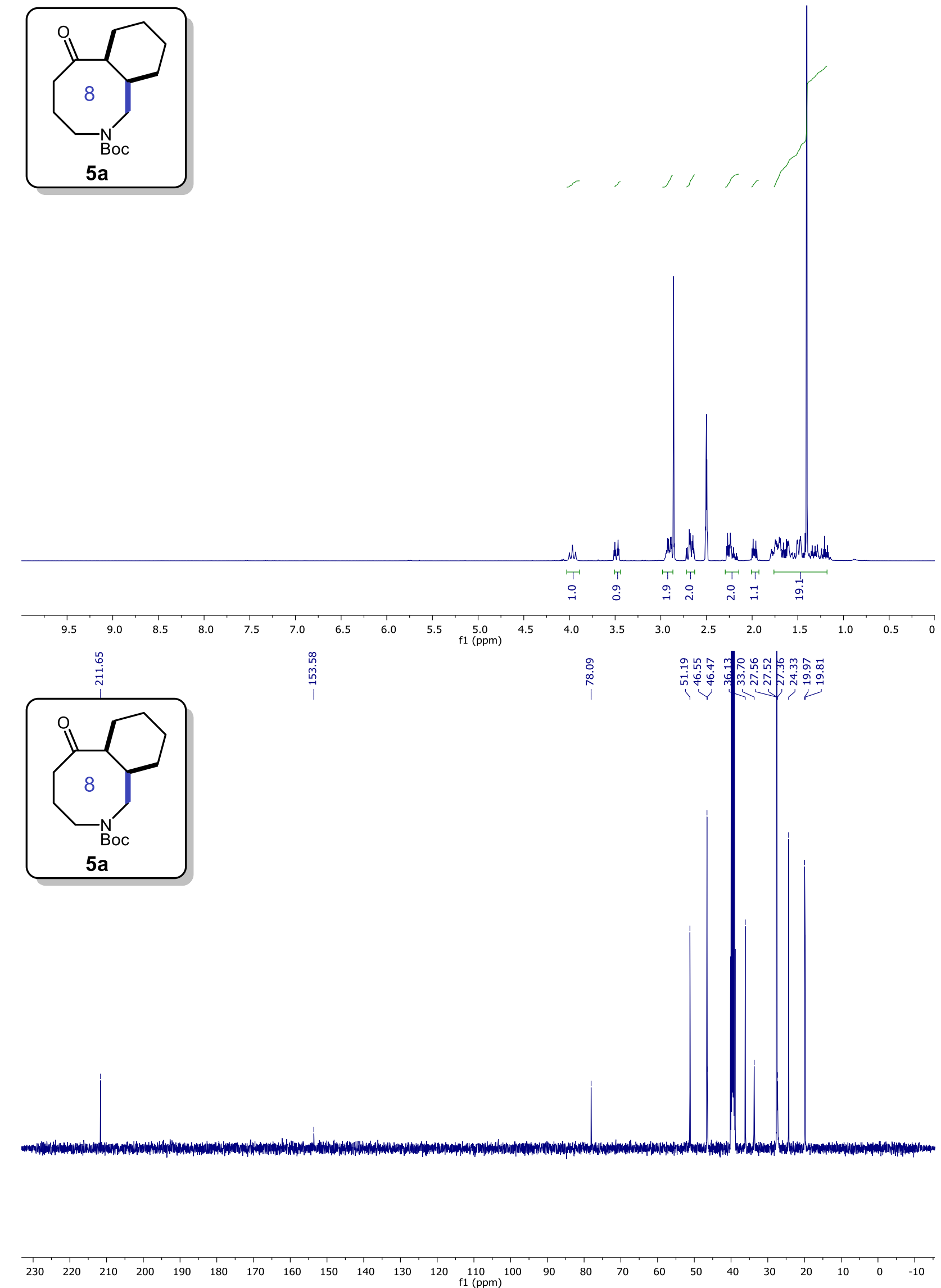

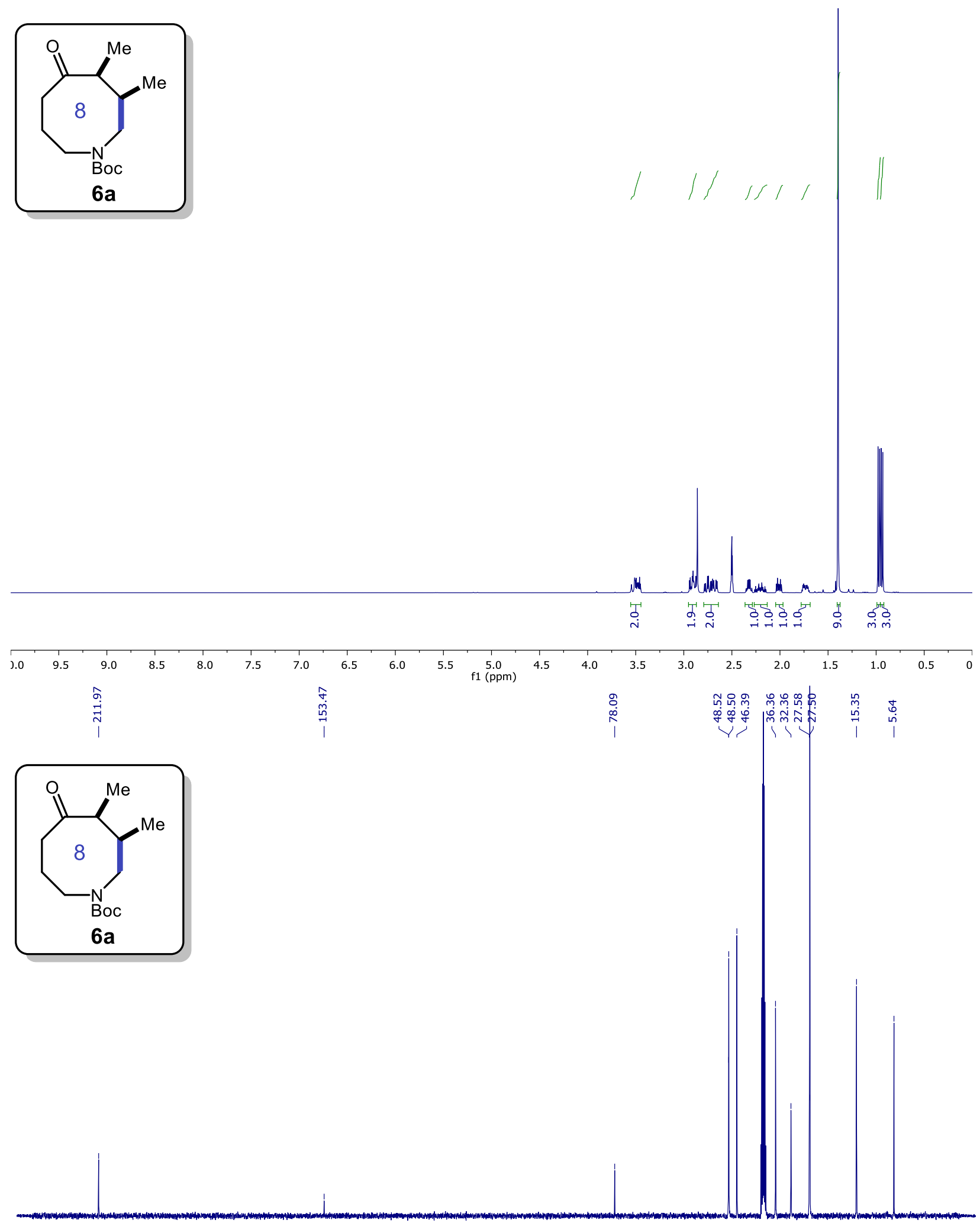

\begin{tabular}{llllllllllllllllllllllllllllllll}
\hline & 230 & 220 & 210 & 200 & 190 & 180 & 170 & 160 & 150 & 140 & 130 & 120 & 110 & 100 & 90 & 80 & 70 & 60 & 50 & 40 & 30 & 20 & 10 & 0 & -10
\end{tabular} 

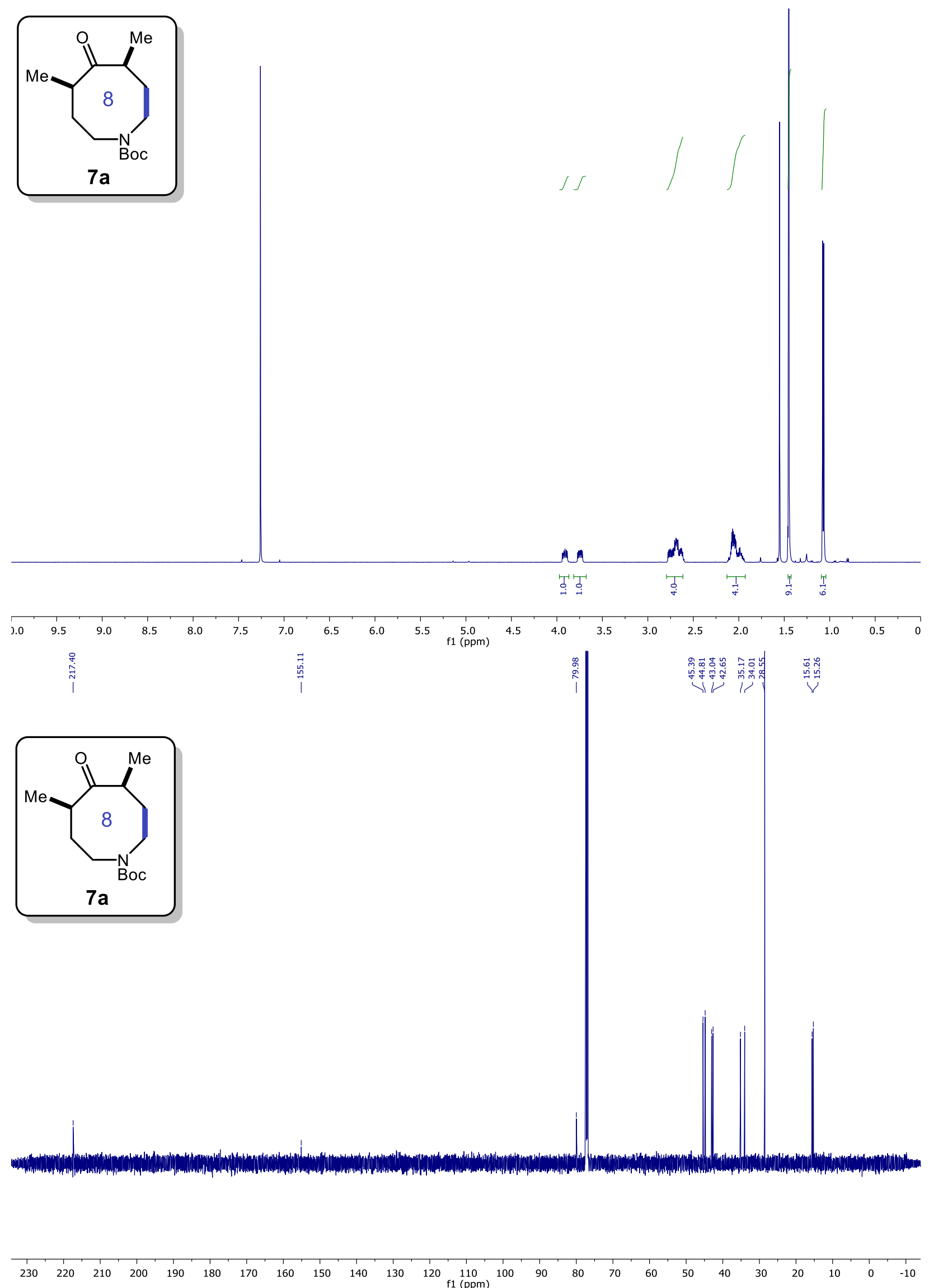

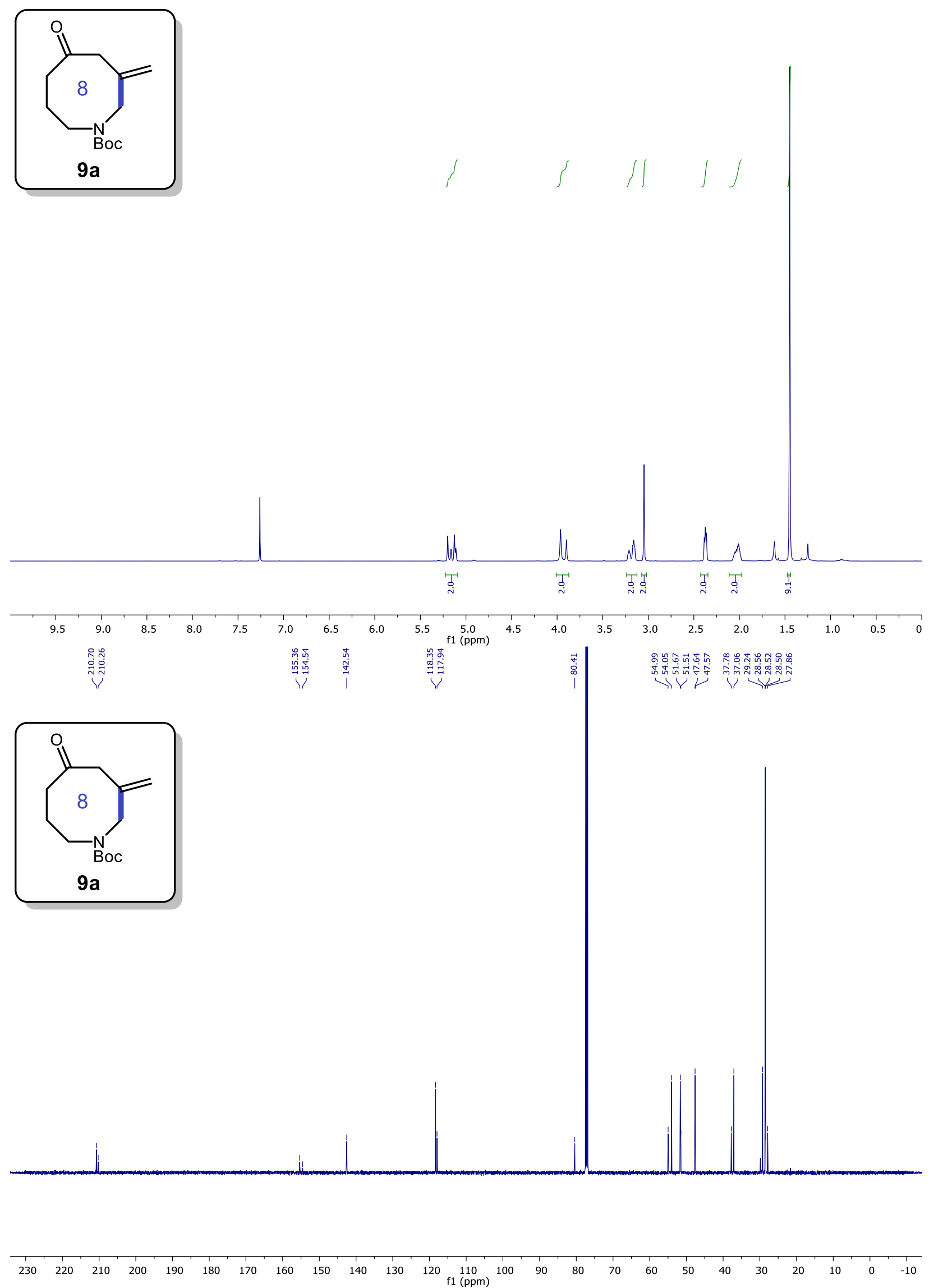

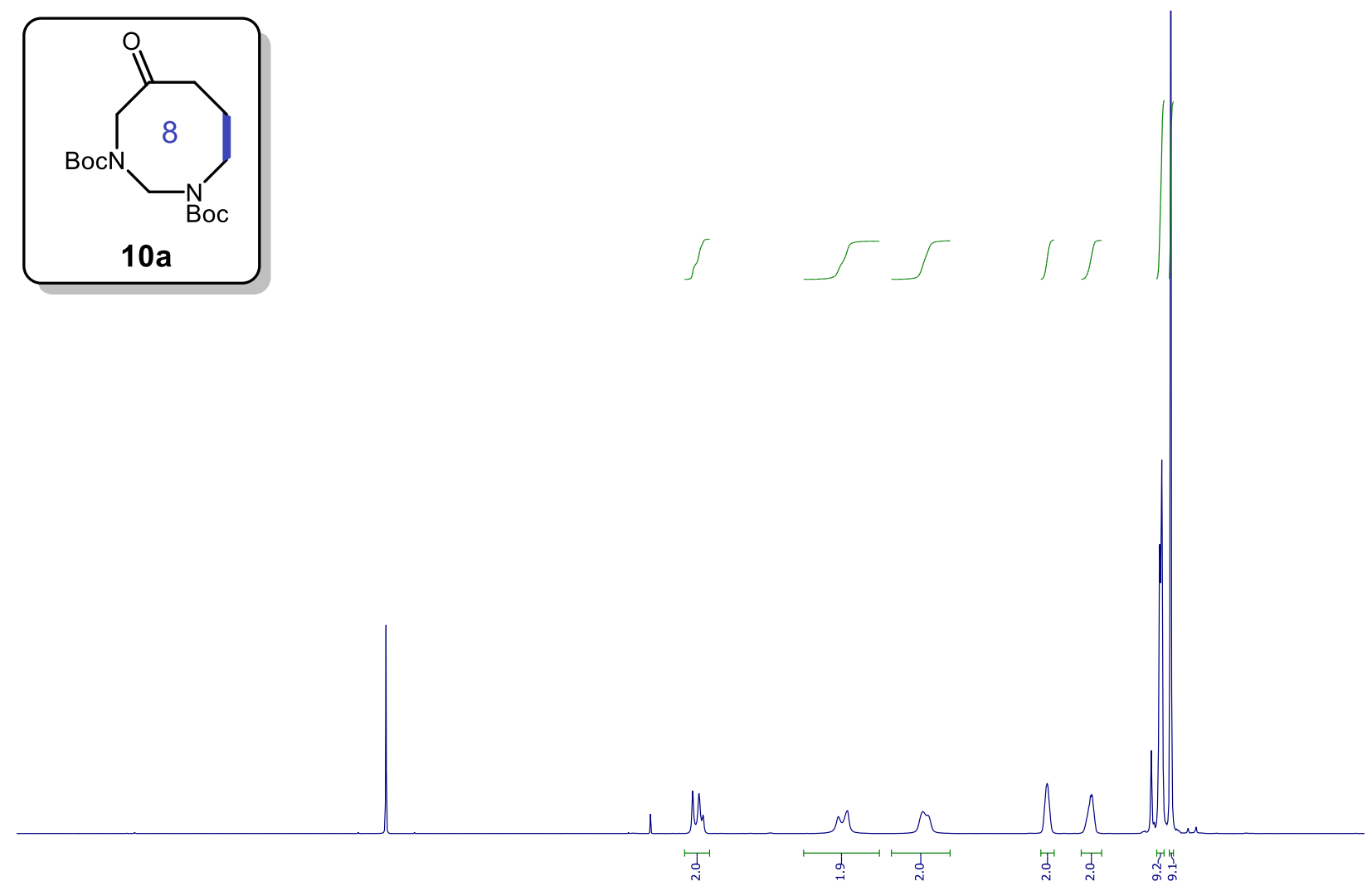

\begin{tabular}{|c|c|c|c|c|c|c|c|c|c|c|c|c|c|c|c|c|c|c|c|}
\hline 3.0 & 9.5 & 9.0 & 8.5 & 8.0 & 7.5 & 7.0 & 6.5 & 6.0 & 5.5 & $\begin{array}{l}5.0 \\
\mathrm{f} 1(\mathrm{ppm})\end{array}$ & 4.5 & 4.0 & 3.5 & 3.0 & 2.5 & $\begin{array}{l}1 \\
2.0\end{array}$ & 1.5 & 1.0 & 0.5 \\
\hline
\end{tabular}

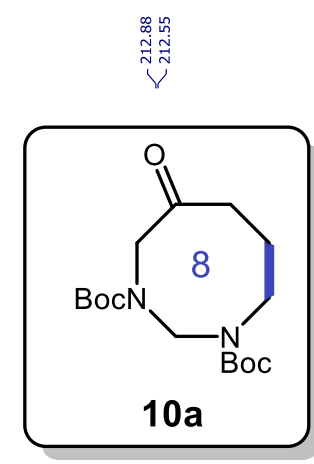

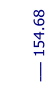

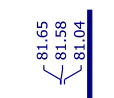

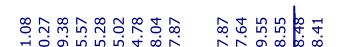
ठํํำน

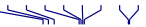

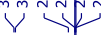




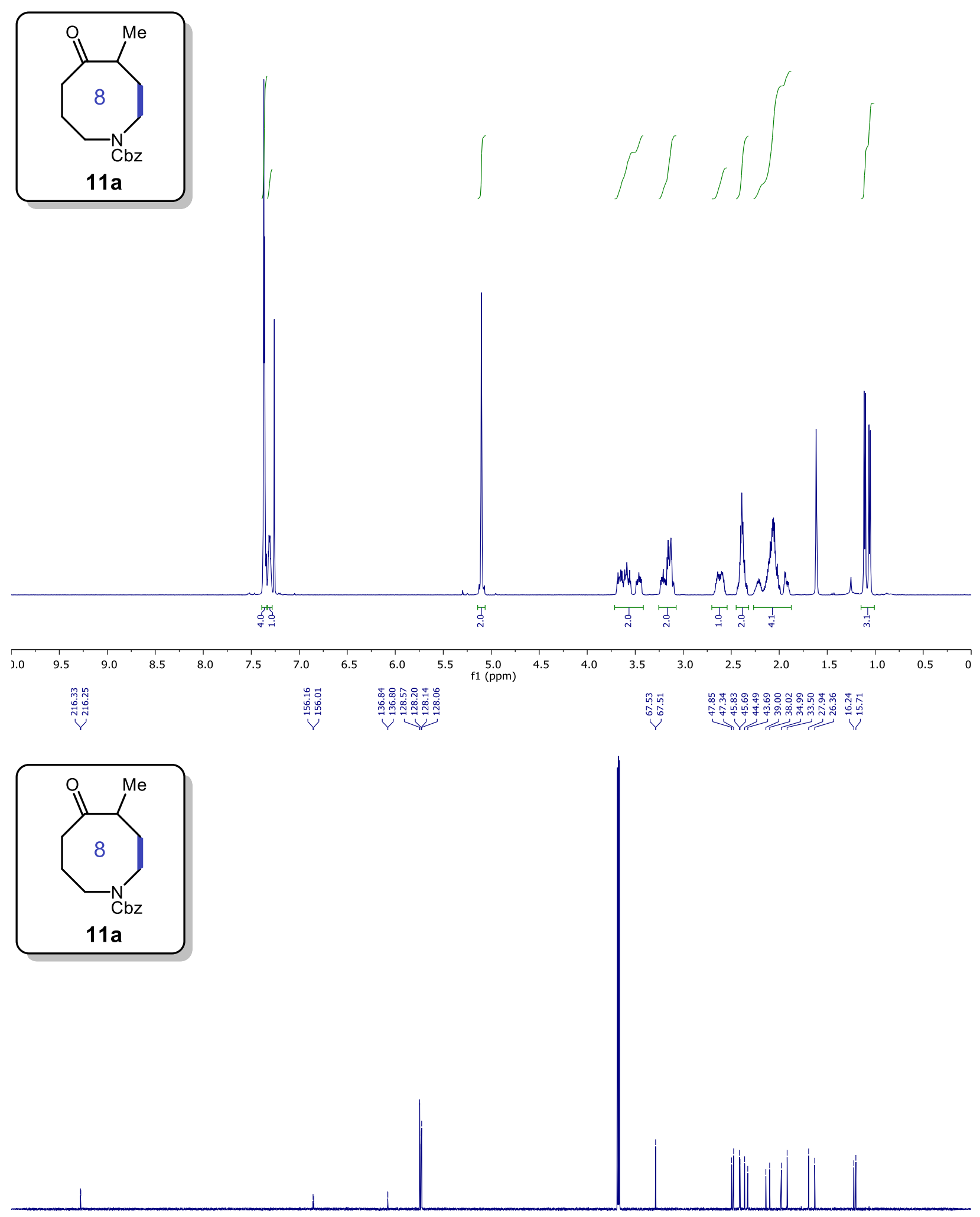

$\begin{array}{lllllllllllllllllllllllllll}230 & 220 & 210 & 200 & 190 & 180 & 170 & 160 & 150 & 140 & 130 & 120 & \begin{array}{l}110 \\ \mathrm{f} 1(\mathrm{ppm})\end{array} & 100 & 90 & 80 & 70 & 60 & 50 & 40 & 30 & 20 & 10 & 0 & -10\end{array}$ S60 

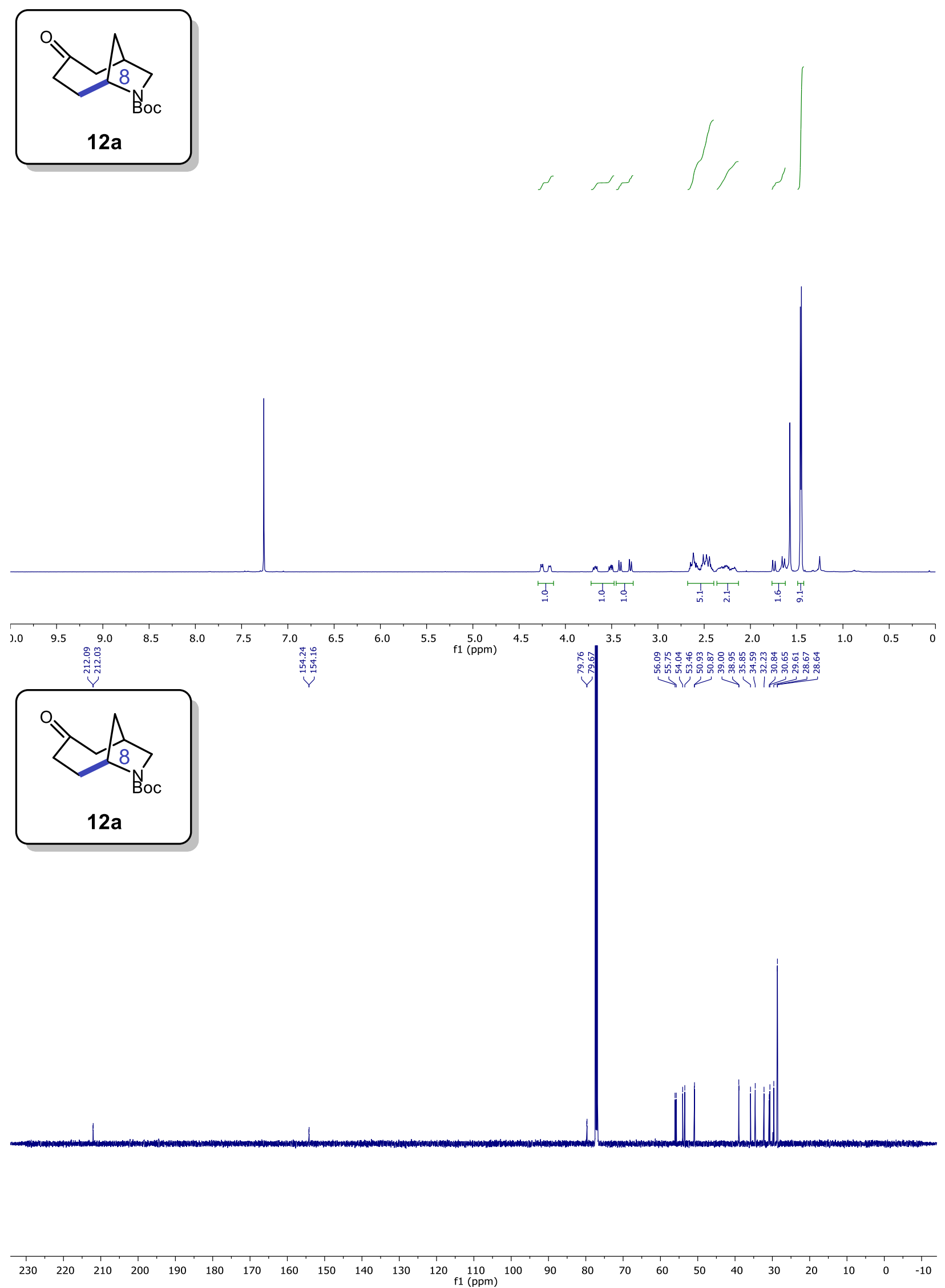

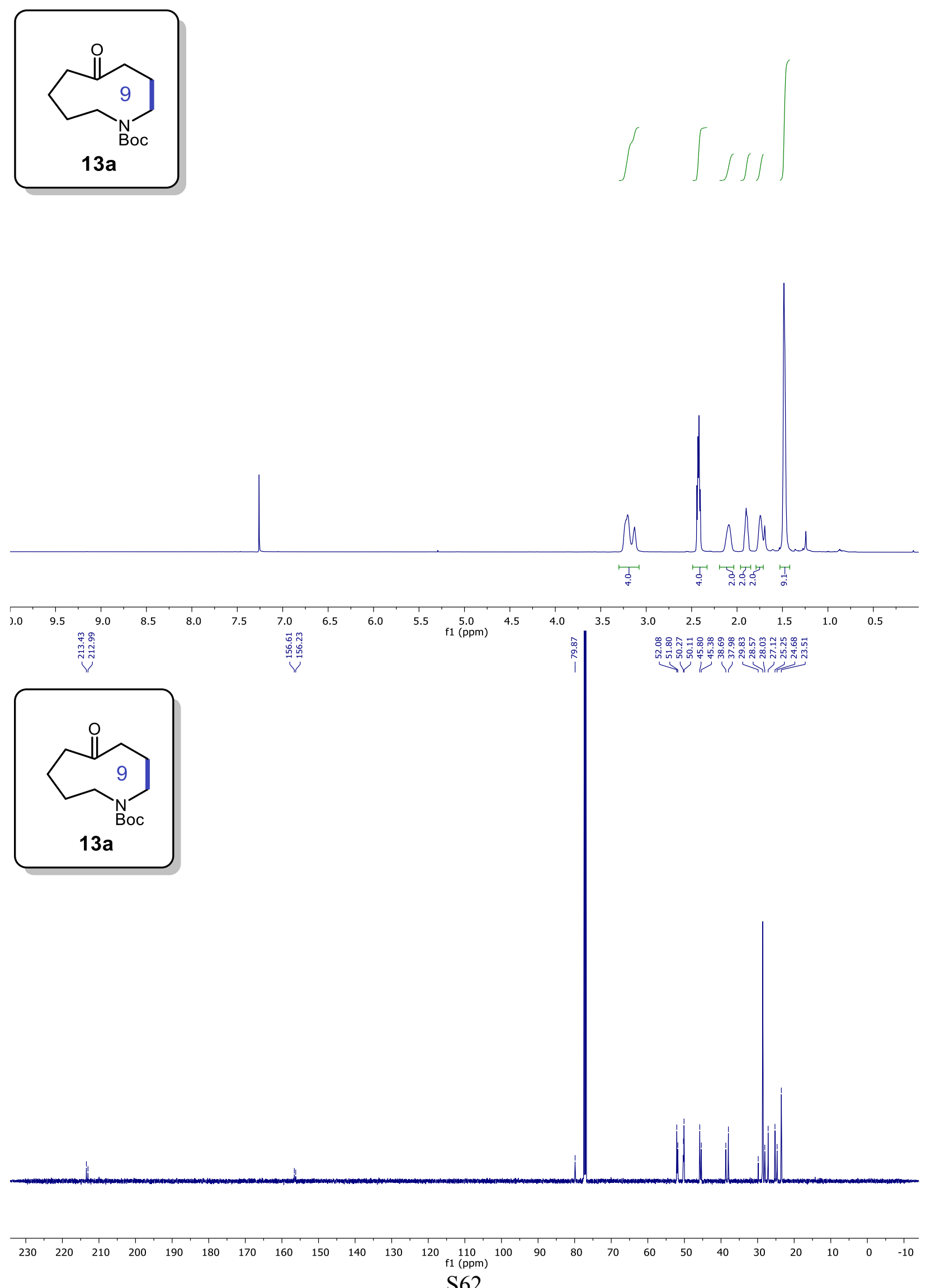

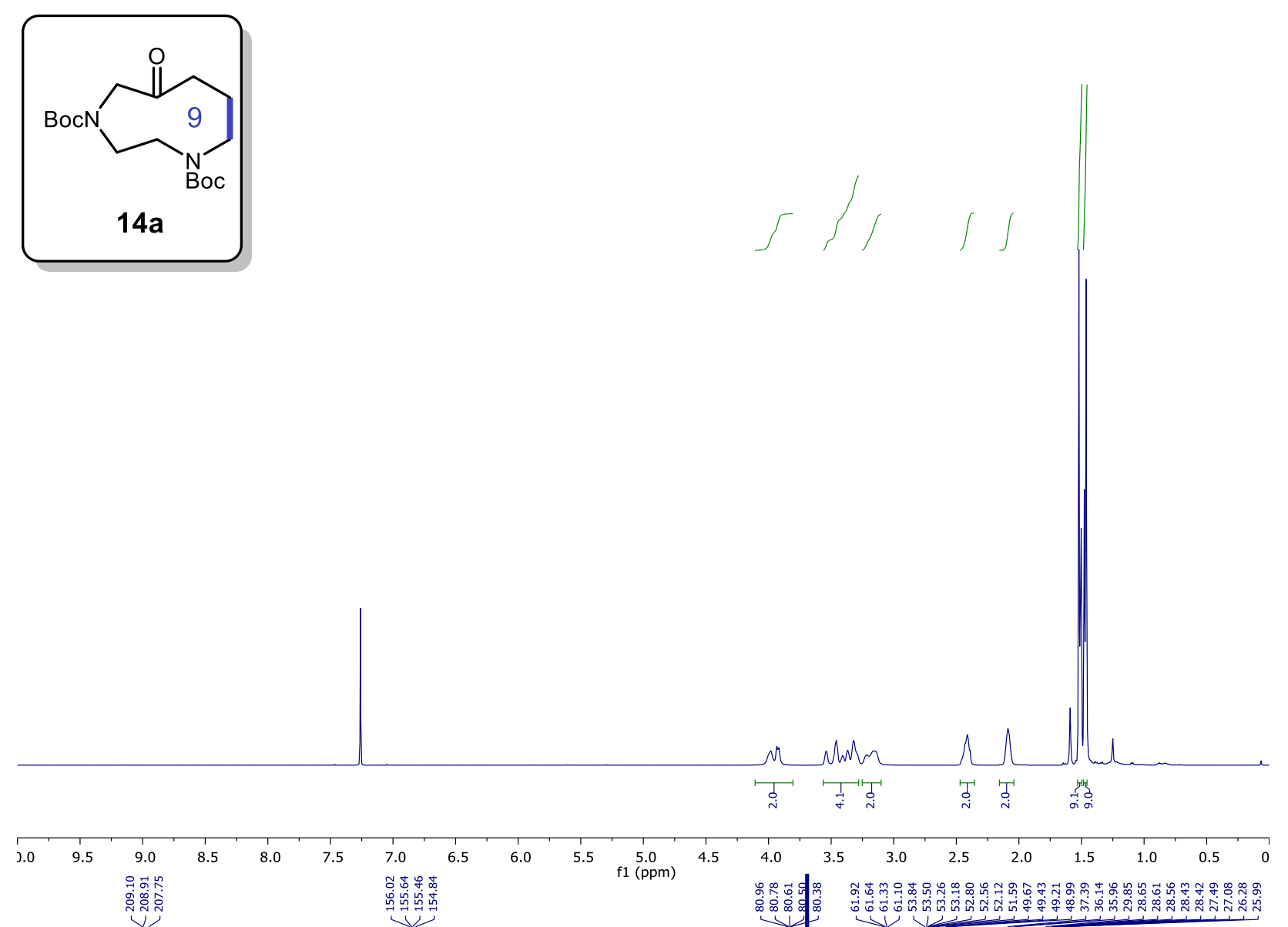

V'

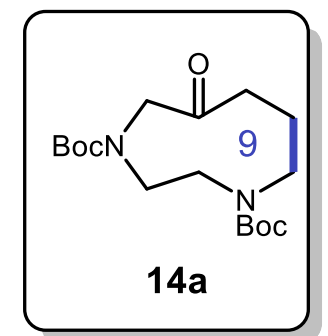

VI 

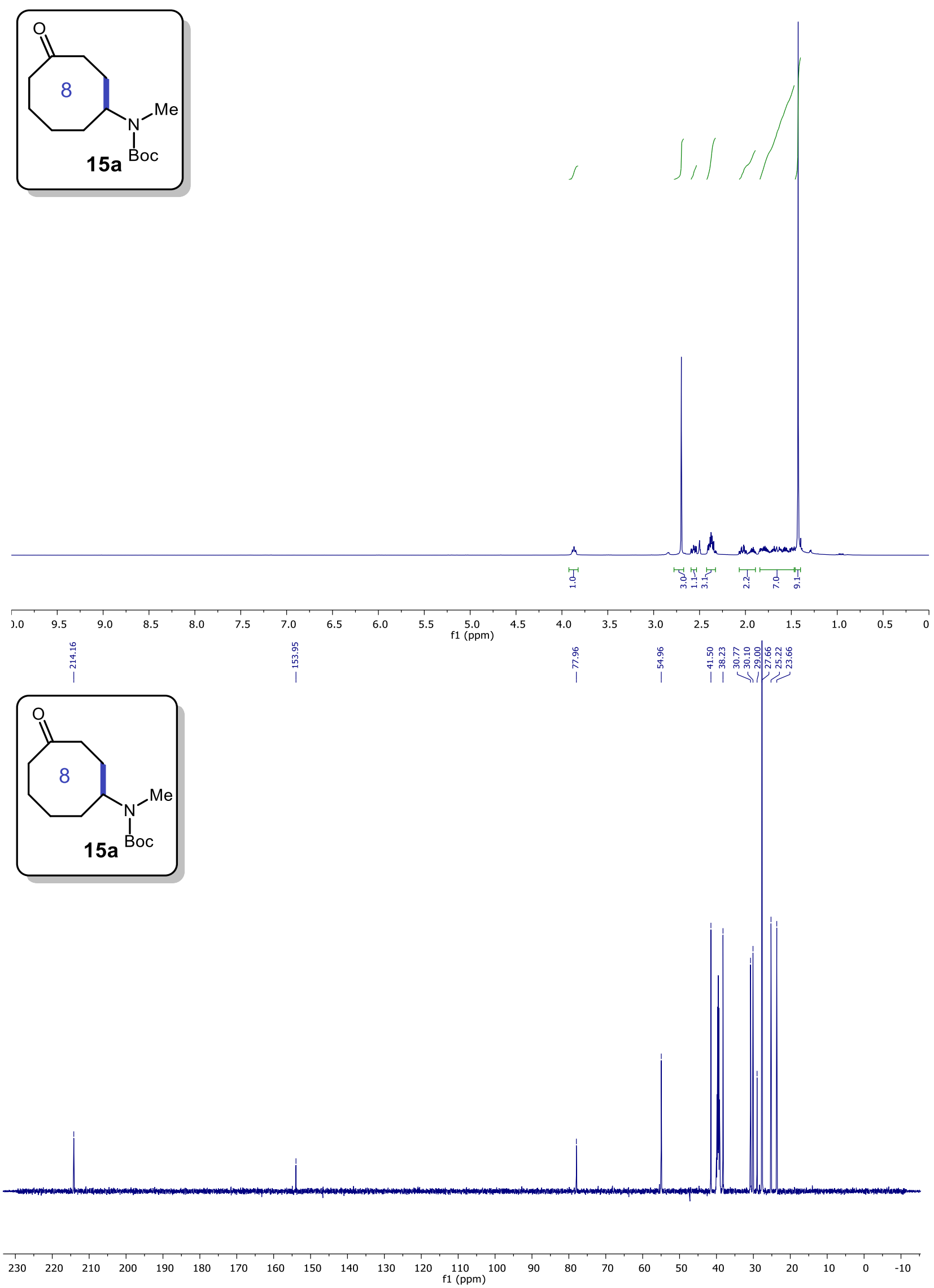

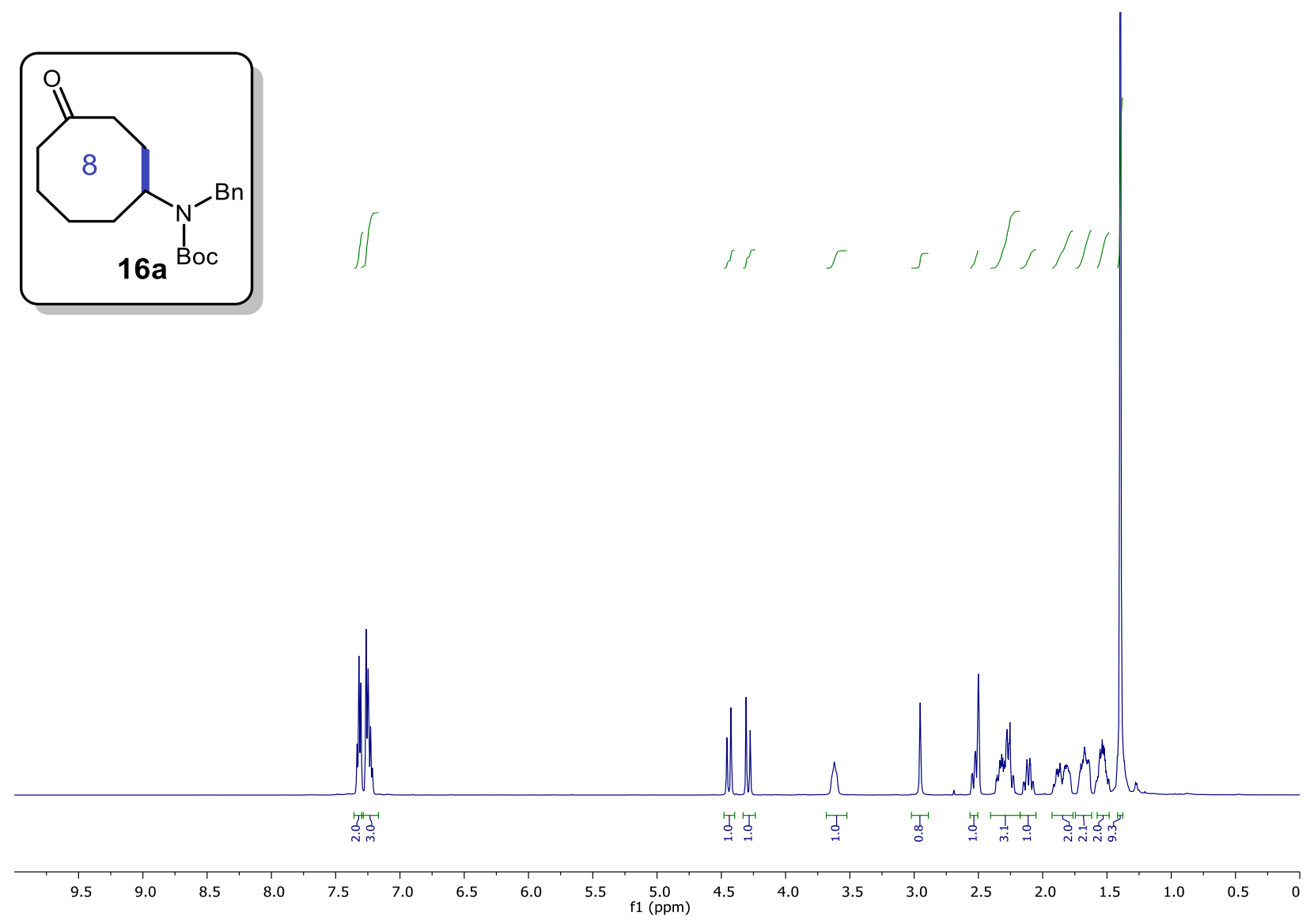

\begin{tabular}{|c|c|c|c|c|c|c|c|}
\hline$\underset{\substack{7 \\
+}}{\stackrel{+}{+}}$ & | & 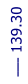 & 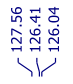 & $\underset{\substack{q \\
\infty}}{\substack{\infty \\
i}}$ & 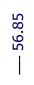 & 号 & 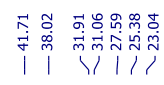 \\
\hline
\end{tabular}
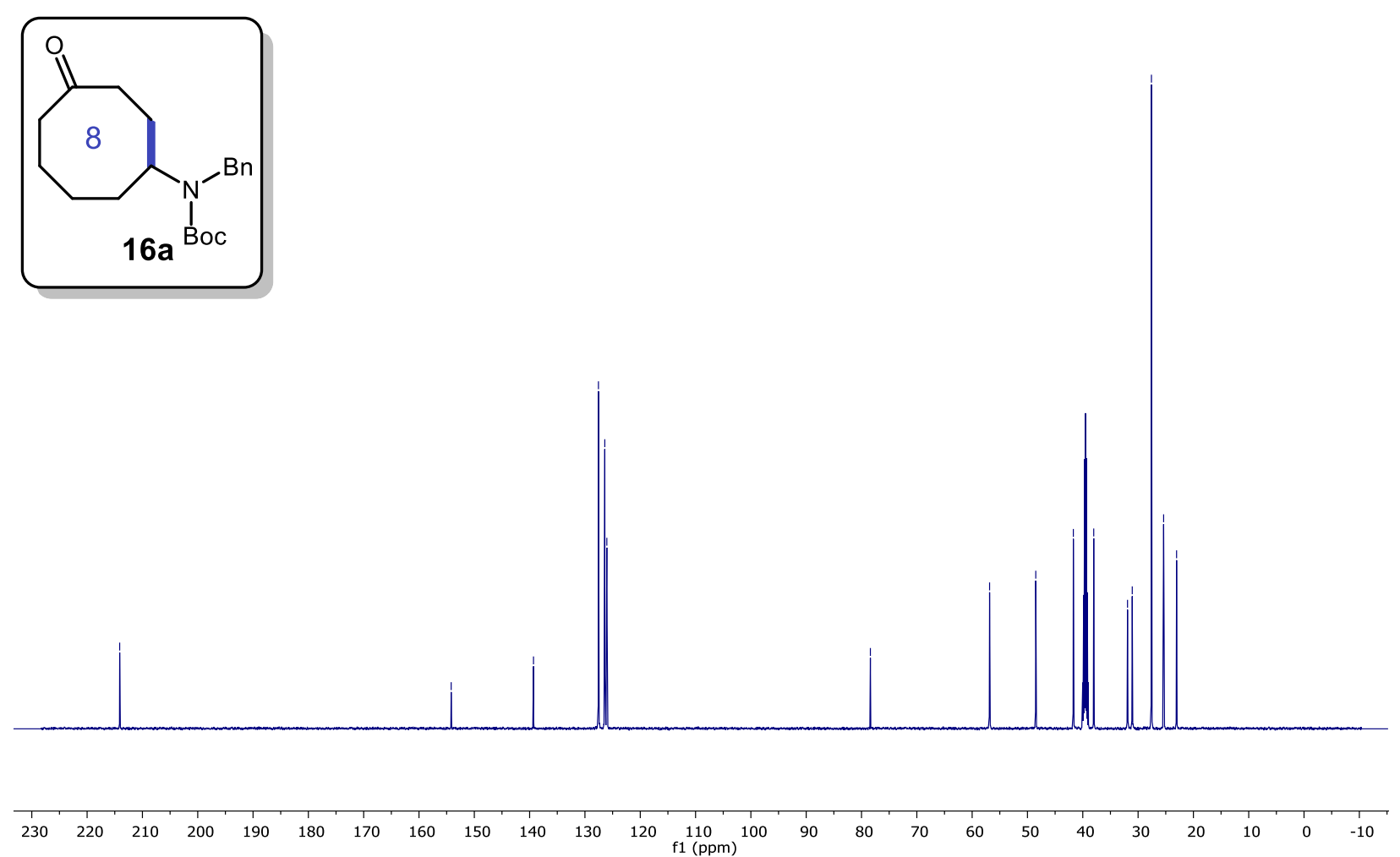

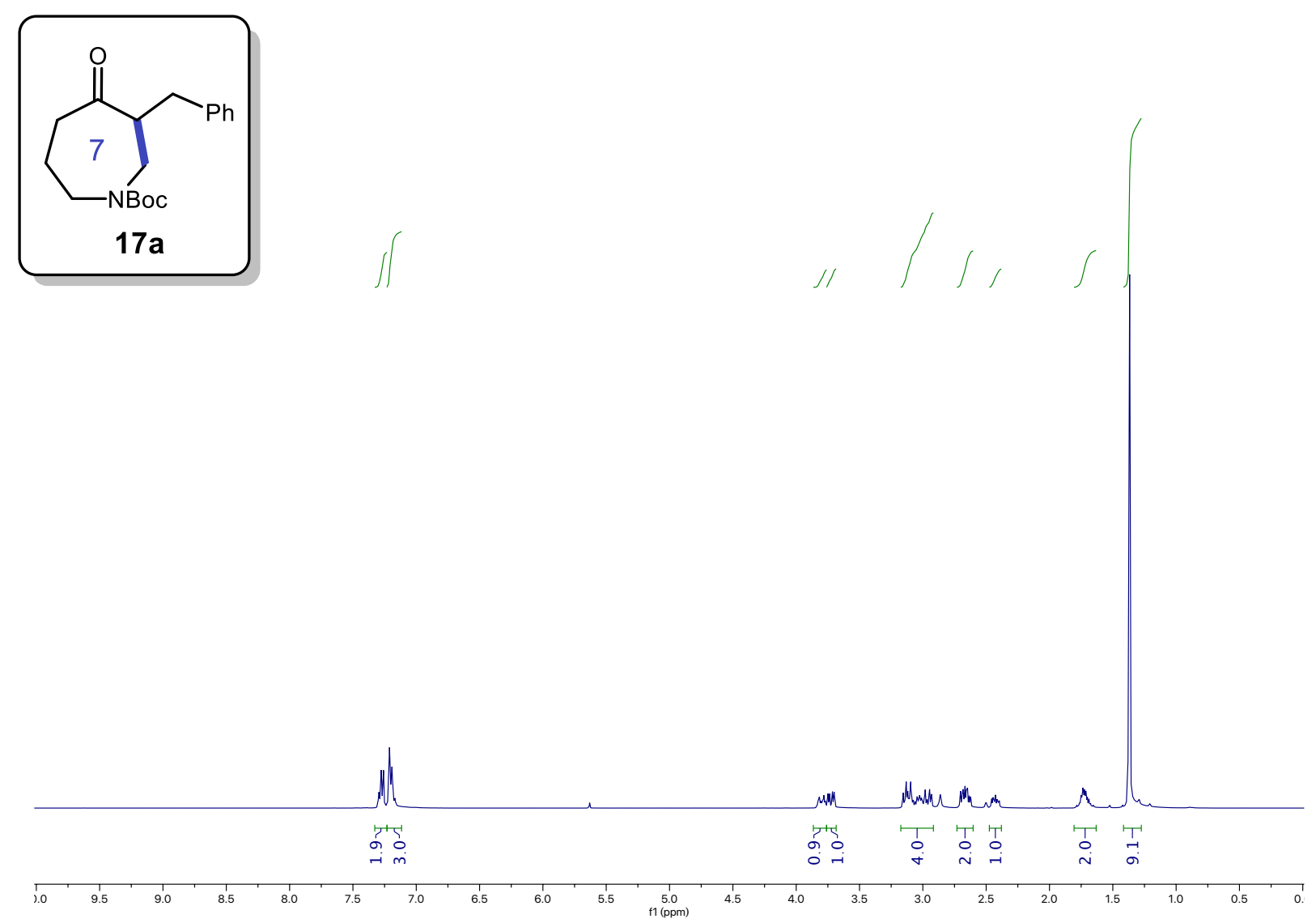

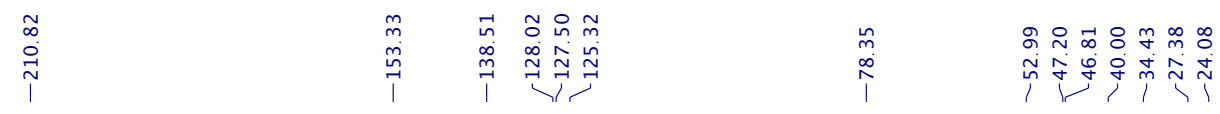
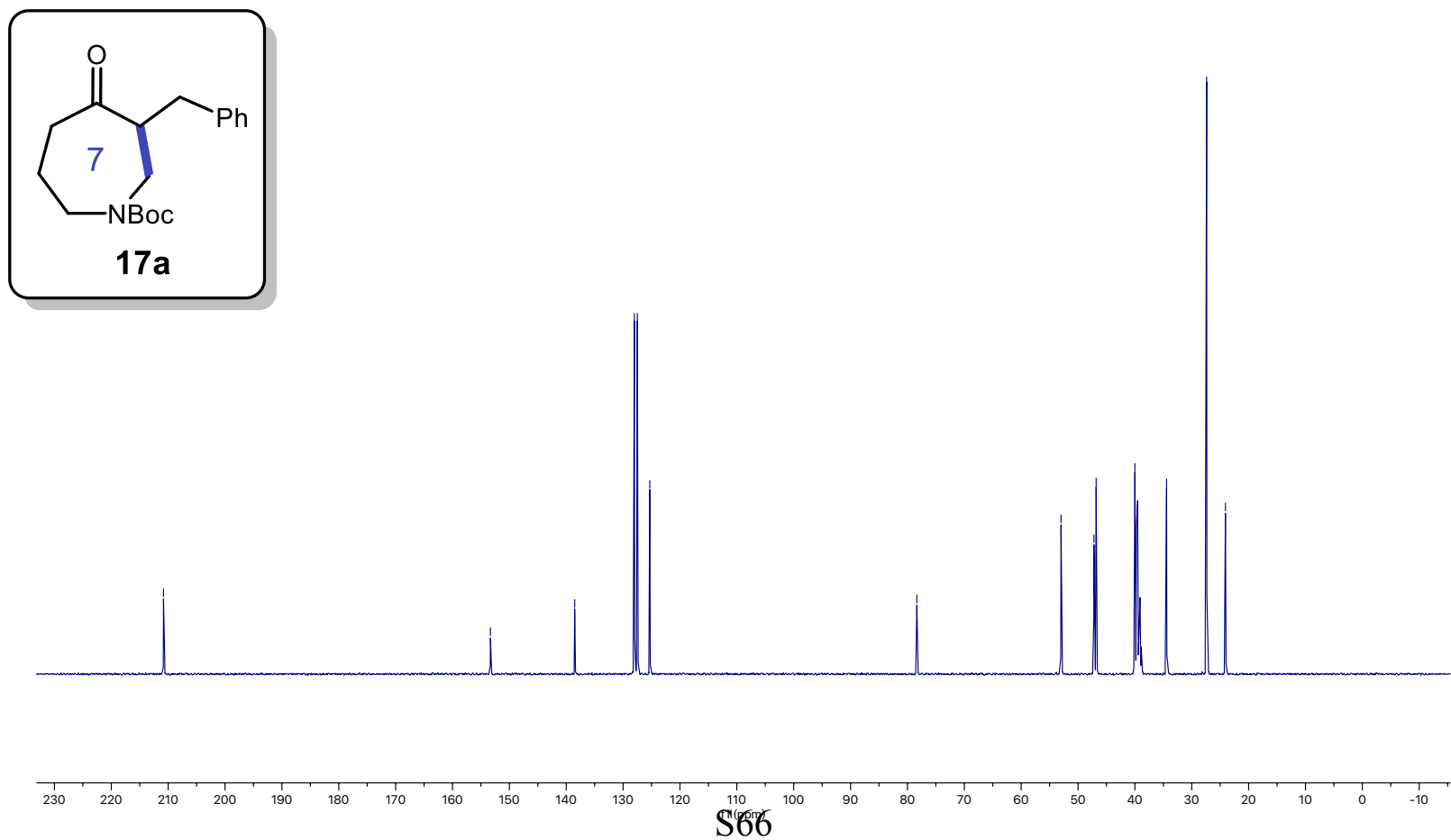

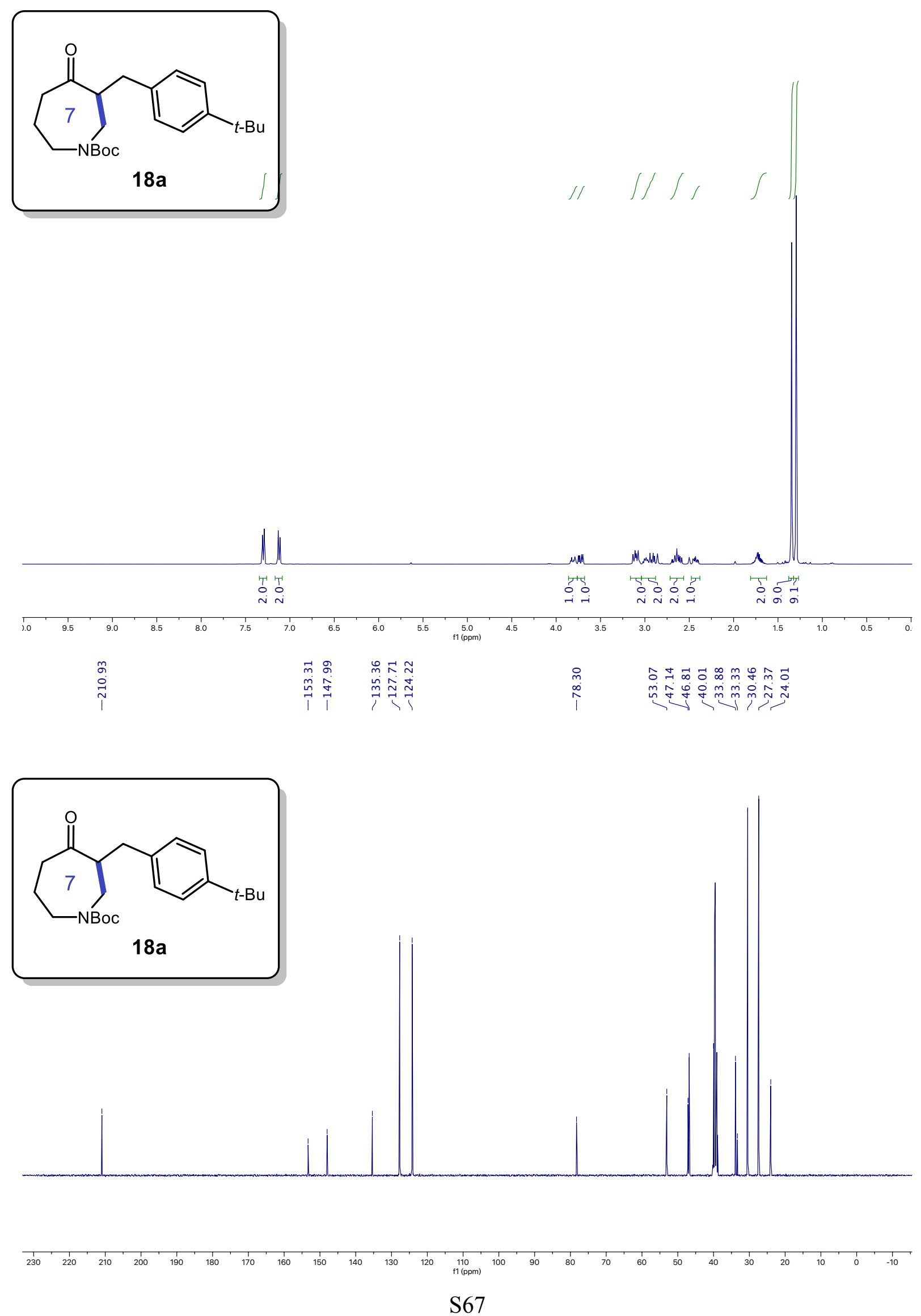

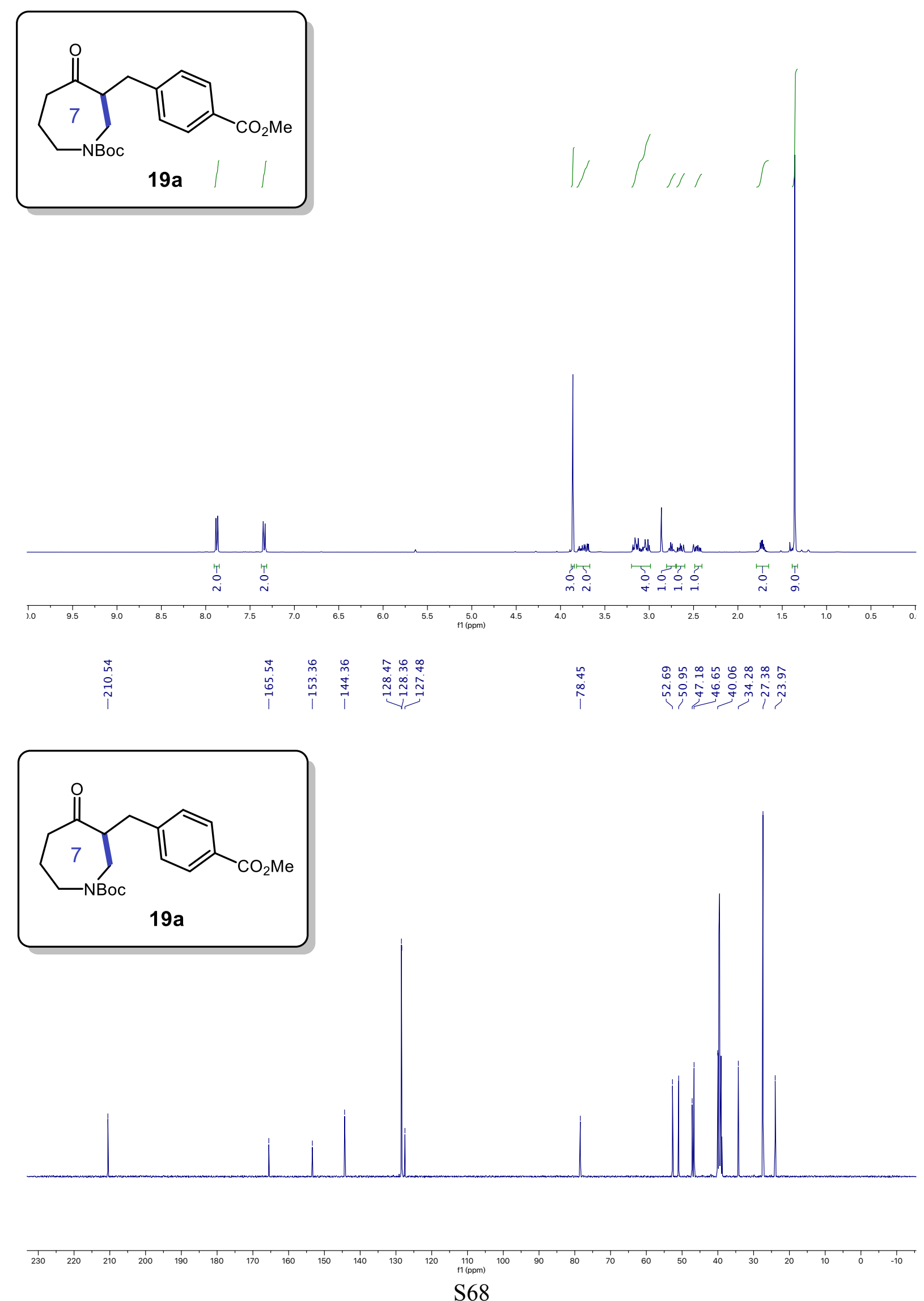

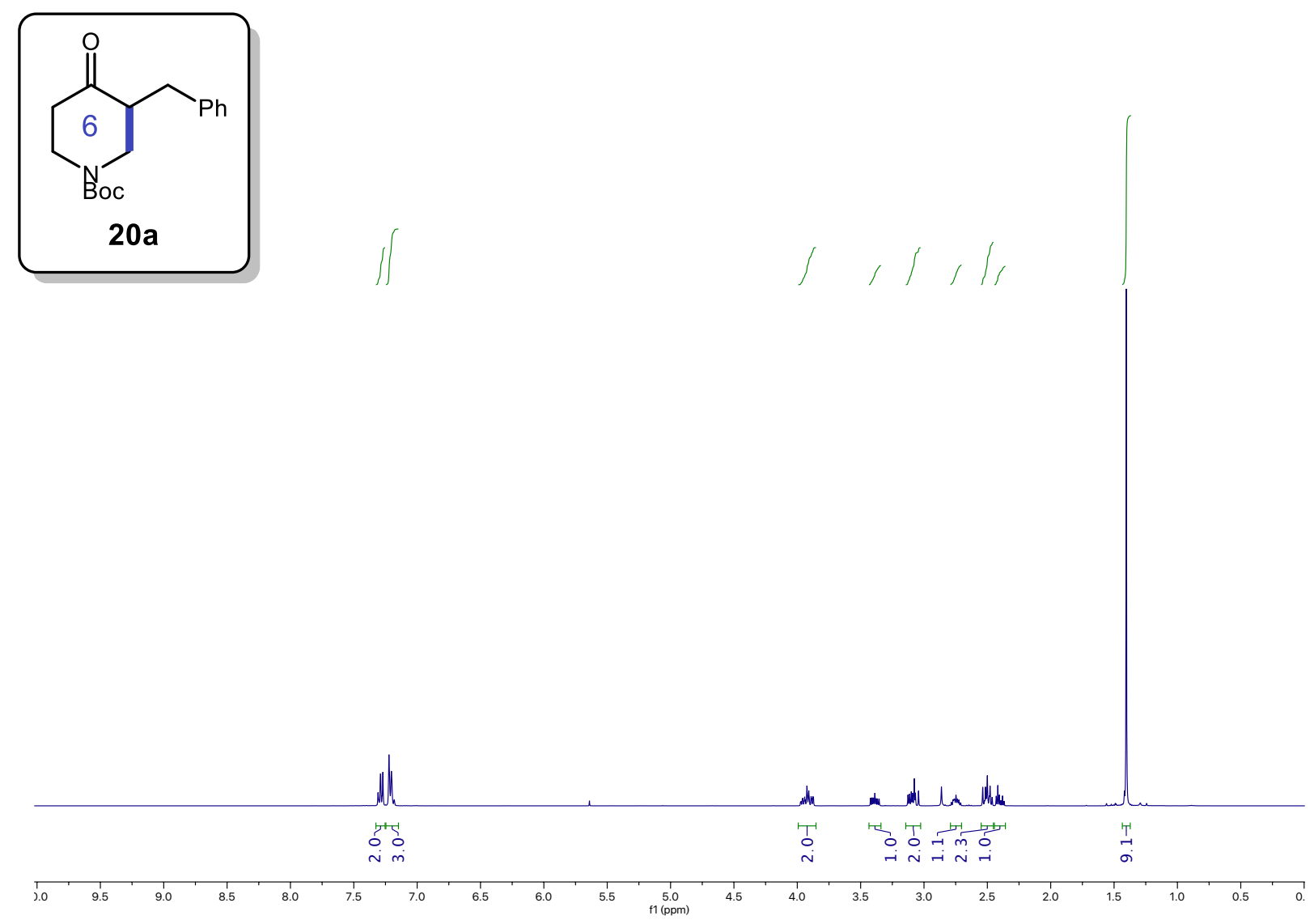

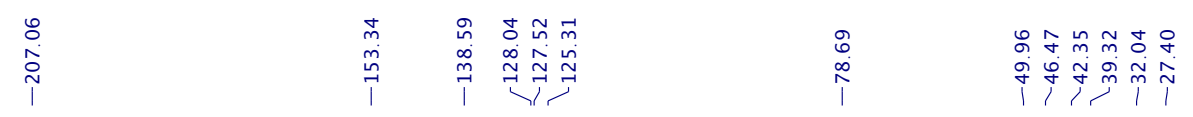
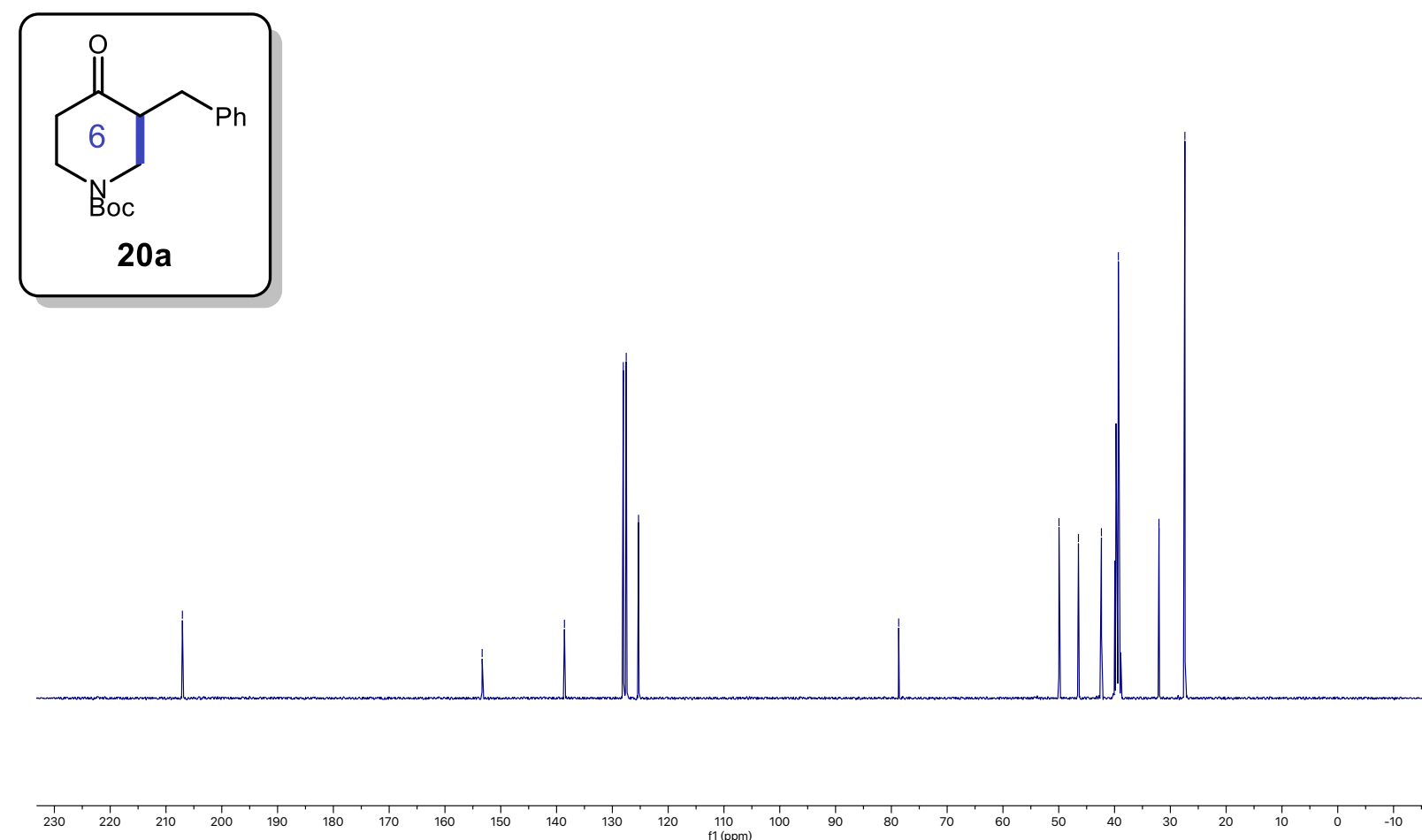

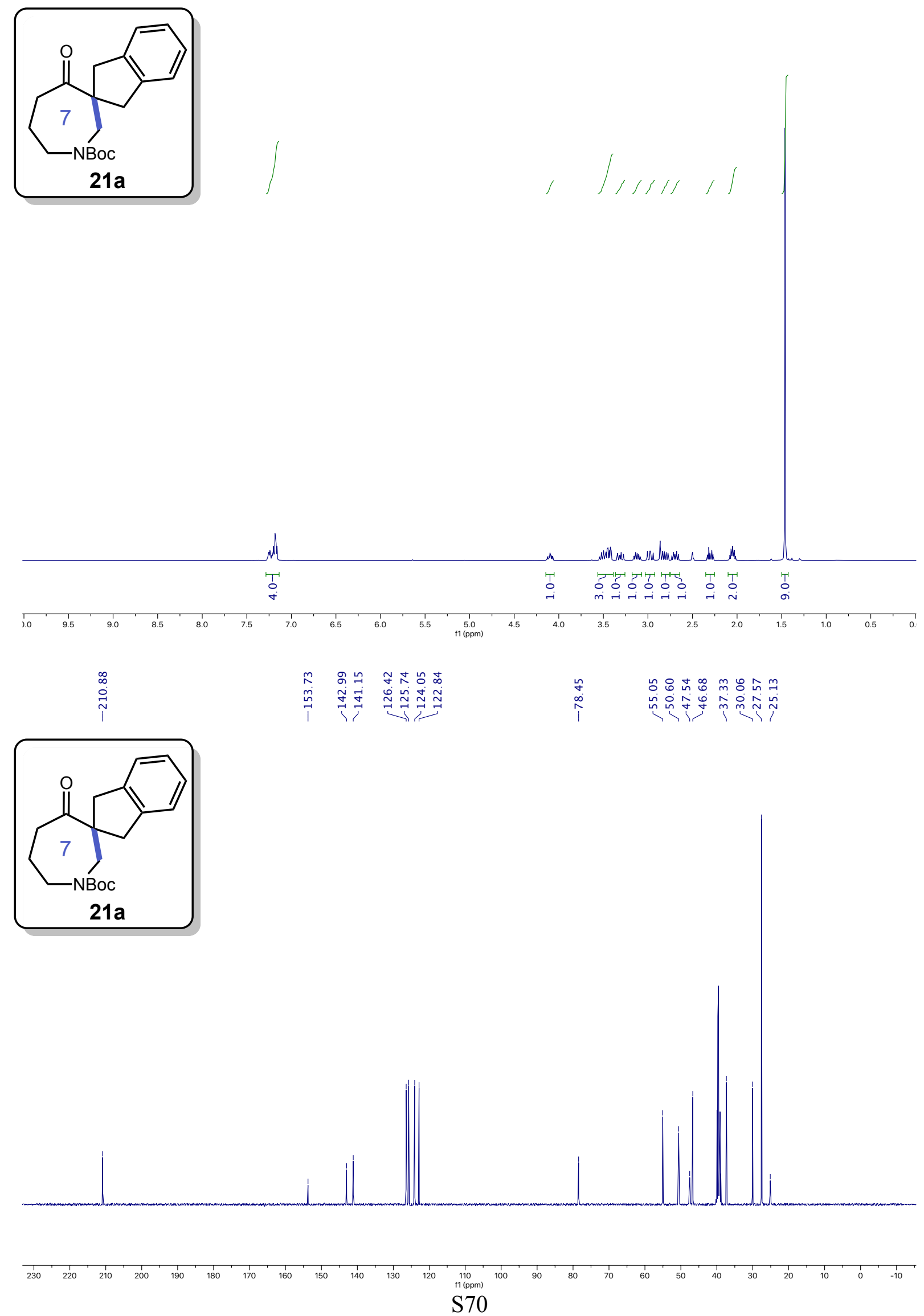

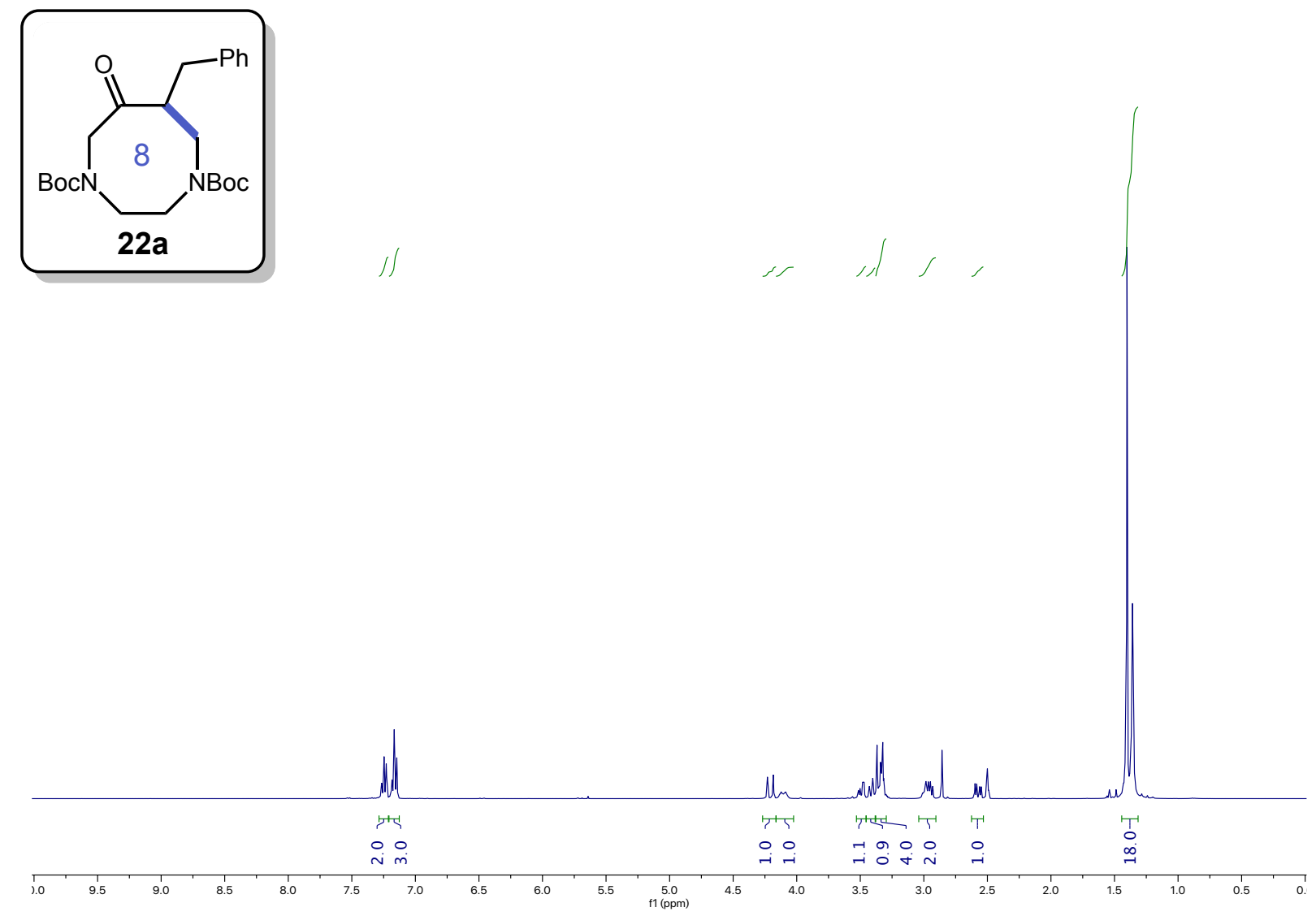

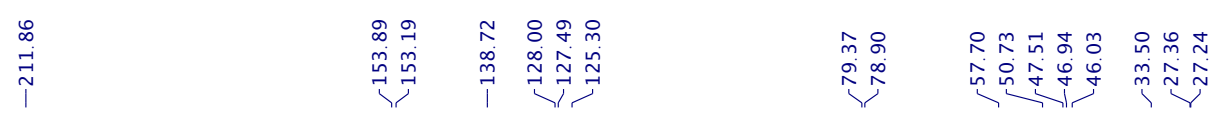
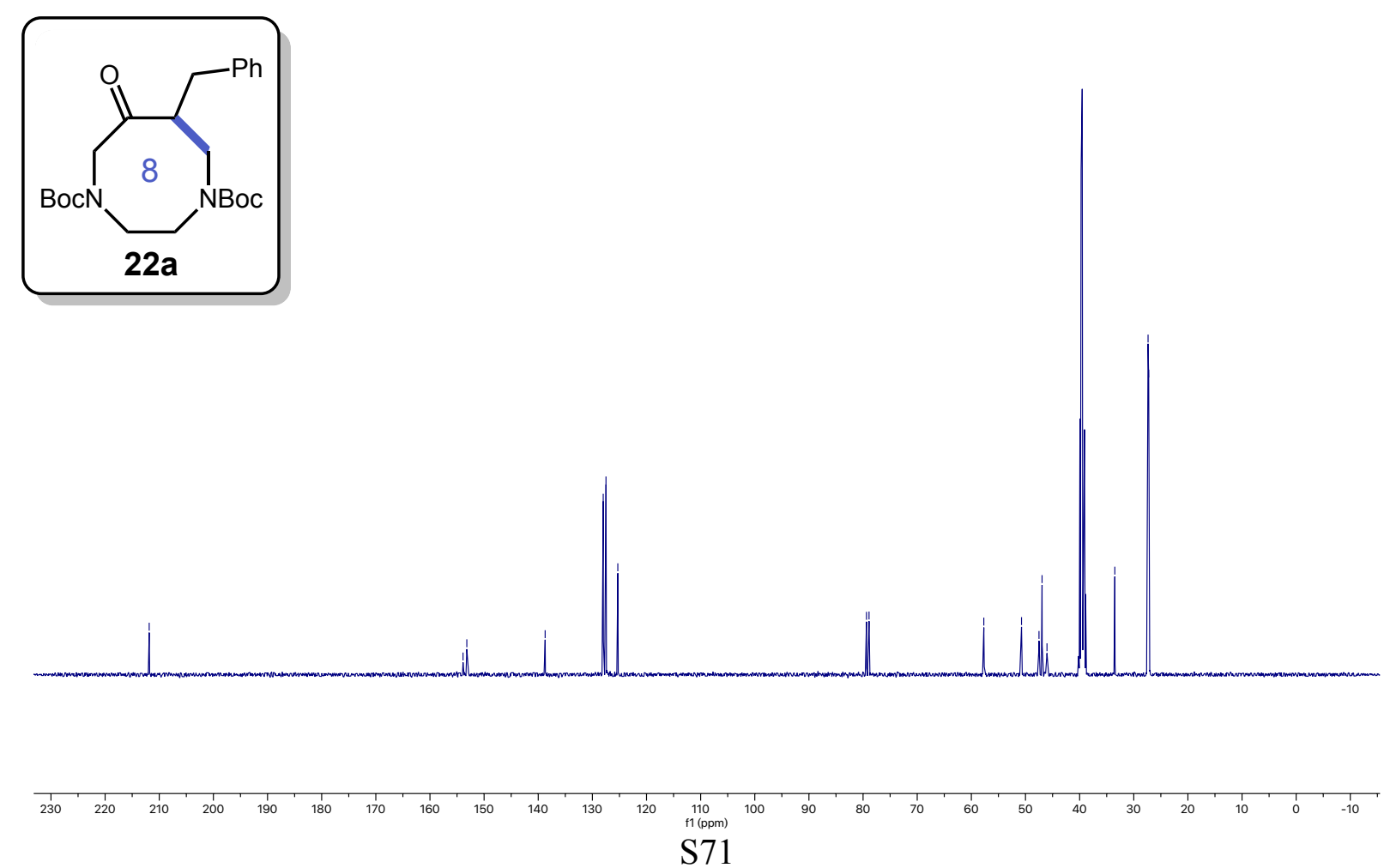

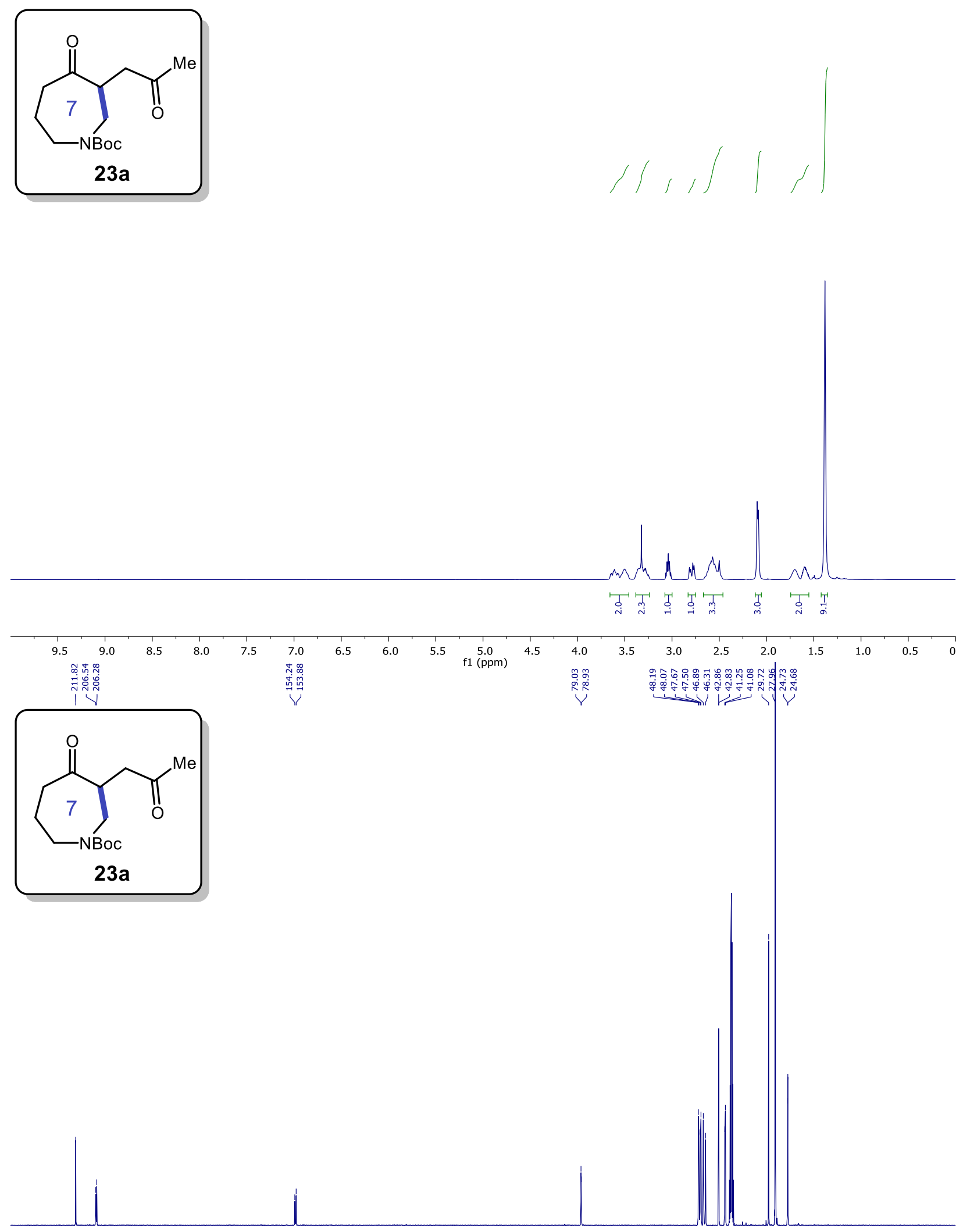

\begin{tabular}{|c|c|c|c|c|c|c|c|c|c|c|c|c|c|c|c|c|c|c|c|c|c|c|c|}
\hline 220 & 210 & 200 & 190 & 180 & 170 & 160 & 150 & 140 & 130 & 120 & $\begin{array}{c}110 \\
\mathrm{f} 1 \\
\mathrm{~S}\end{array}$ & $\begin{array}{l}100 \\
\text { opm) } \\
77\end{array}$ & 90 & 80 & 70 & 60 & 50 & 40 & 30 & 20 & 10 & 0 & -10 \\
\hline
\end{tabular}



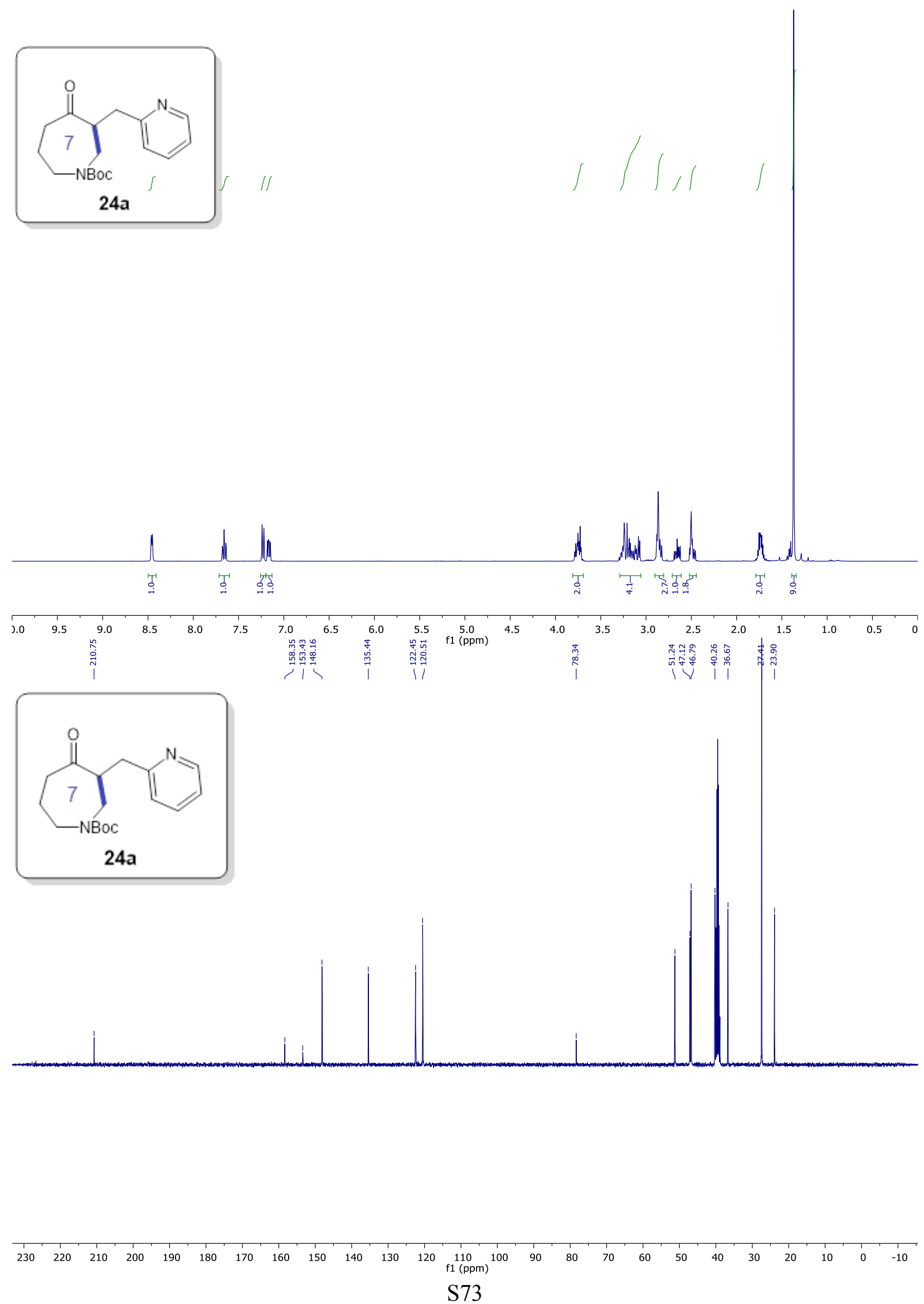

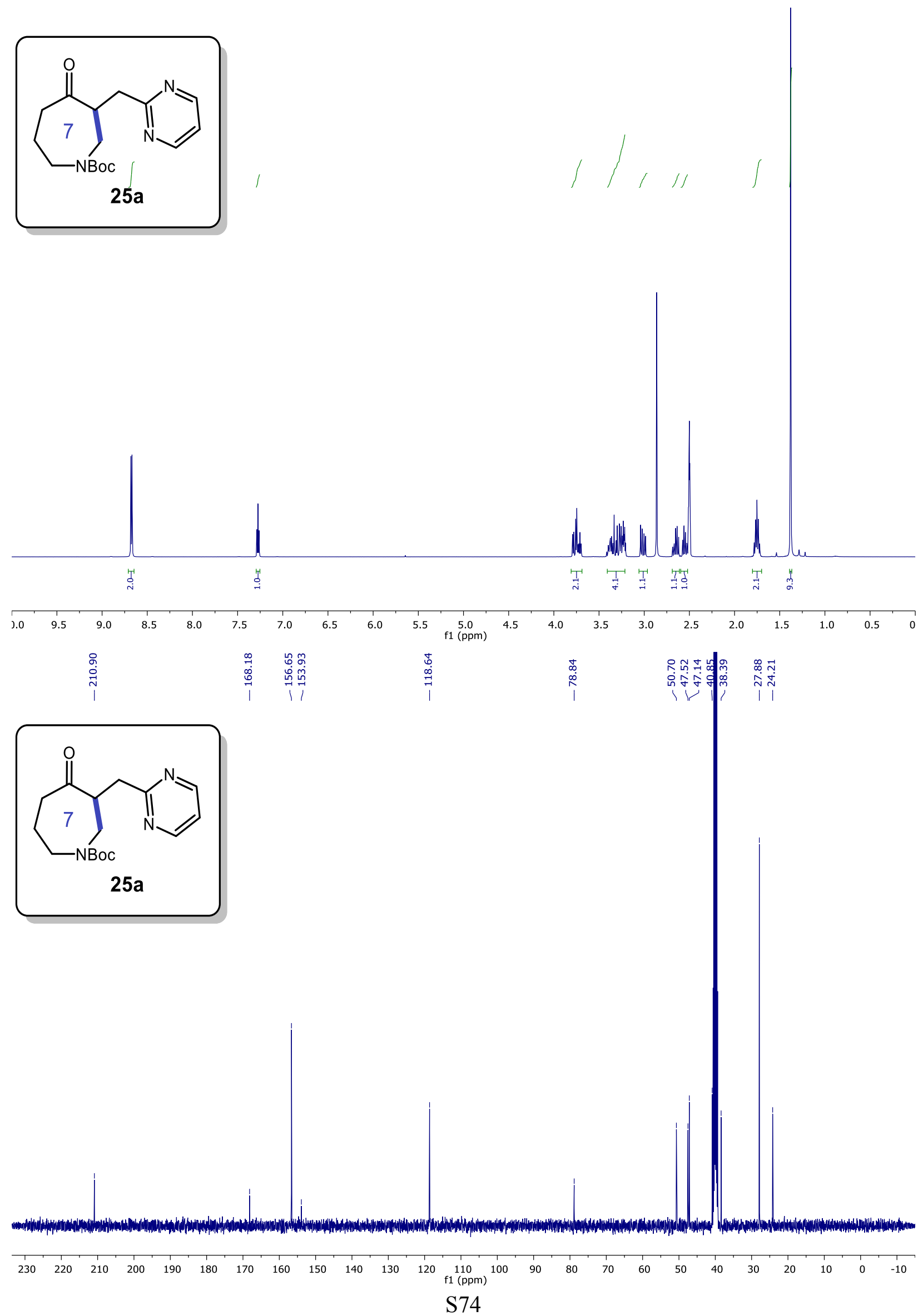

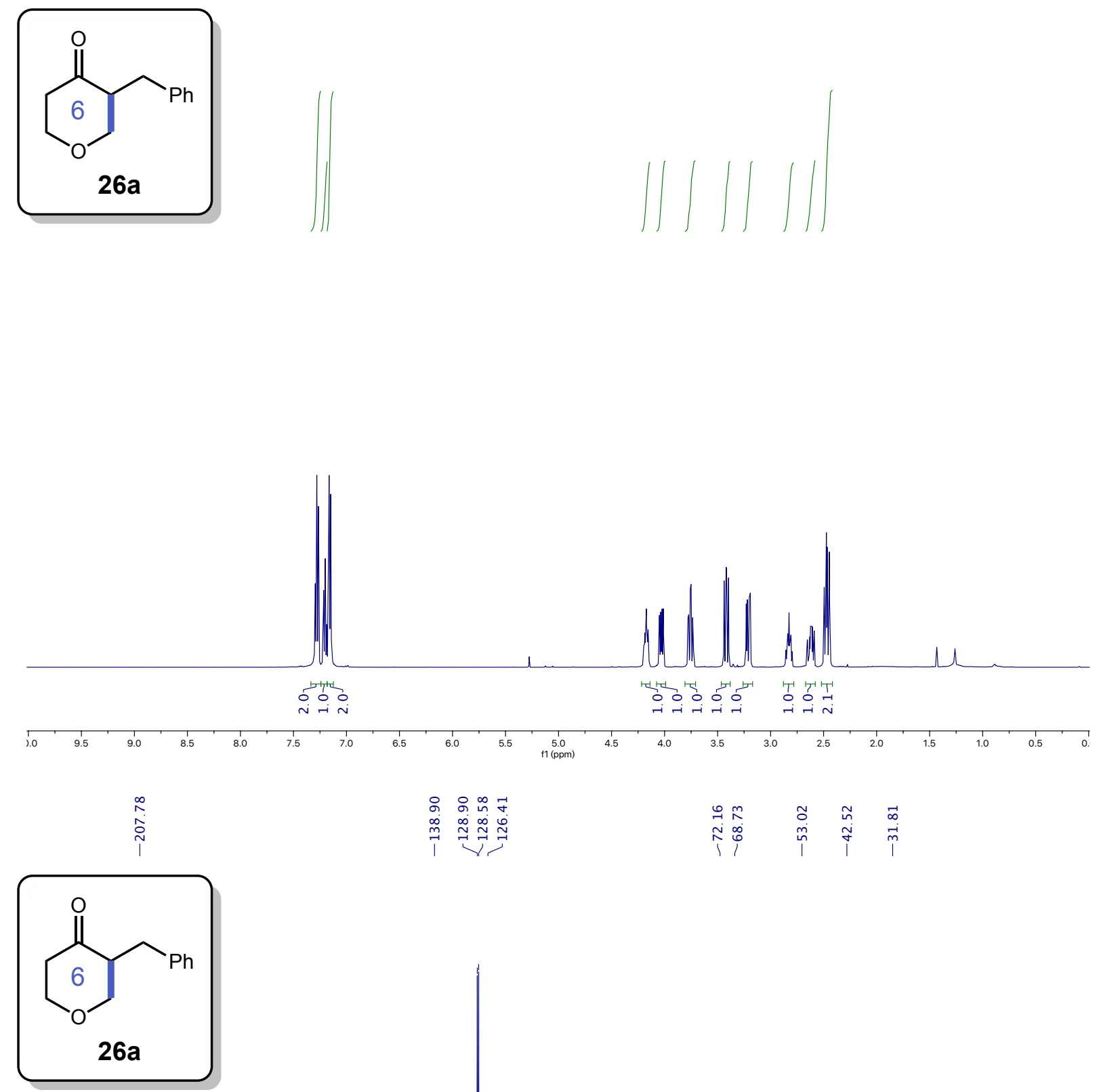

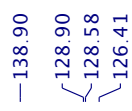

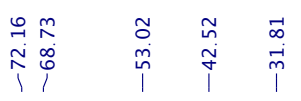

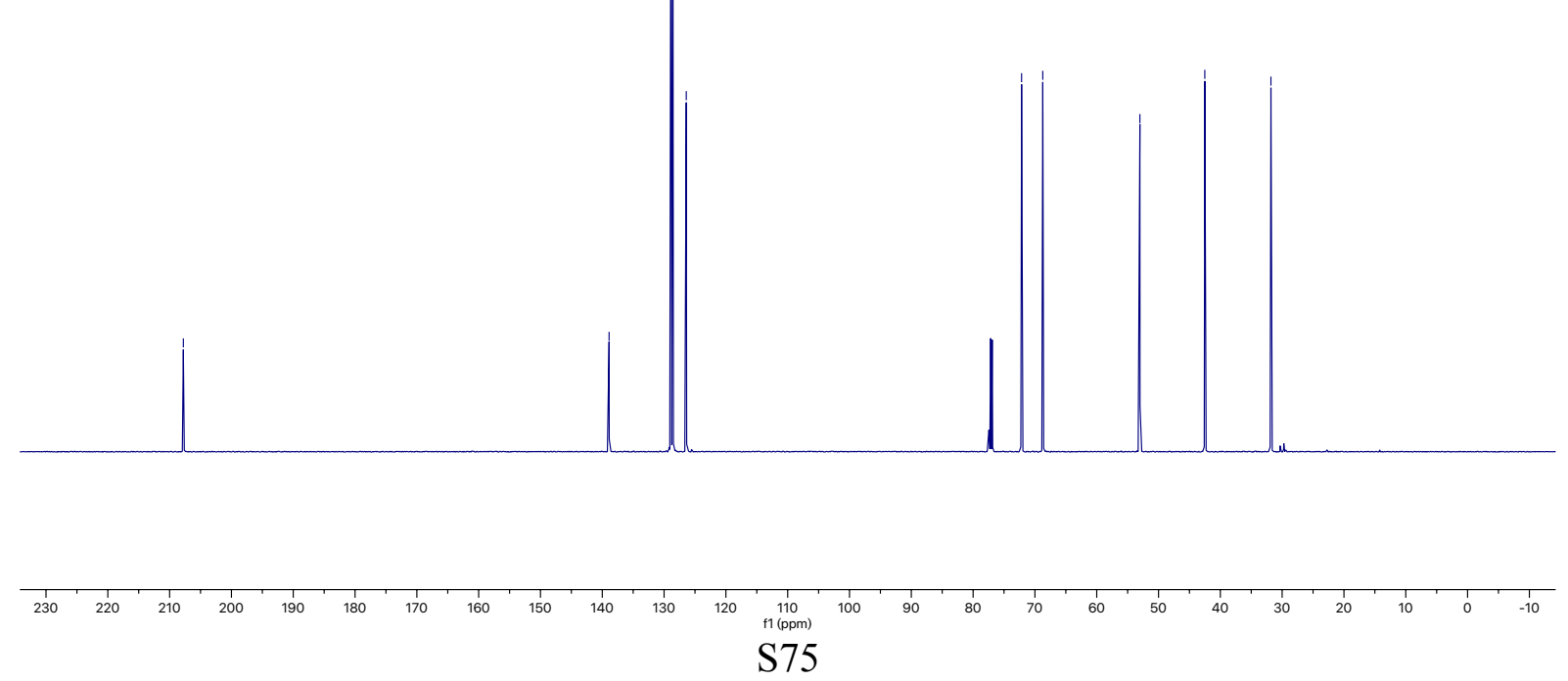



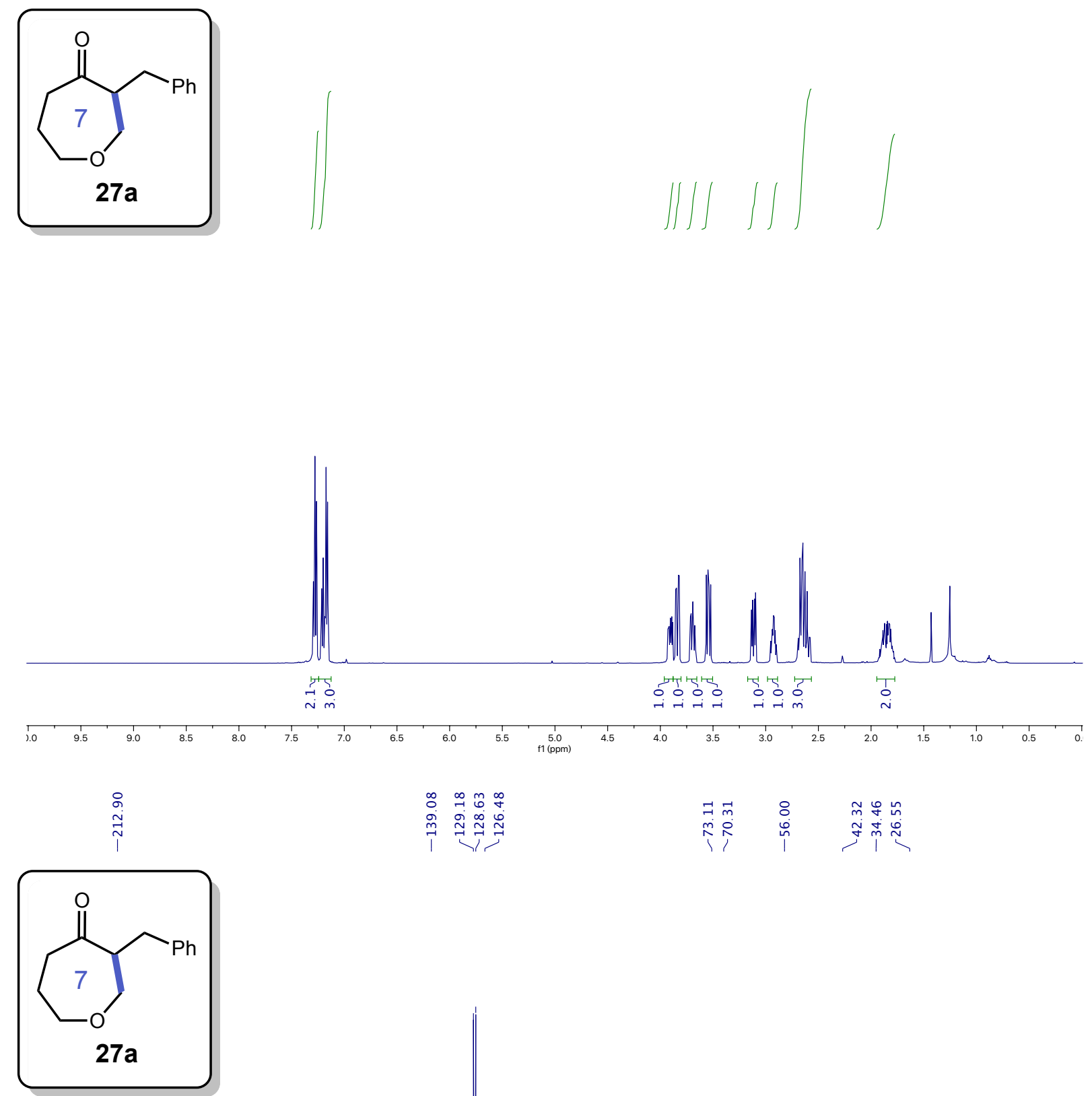

$\infty \infty$

狩

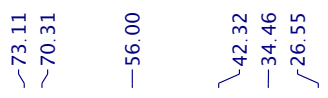
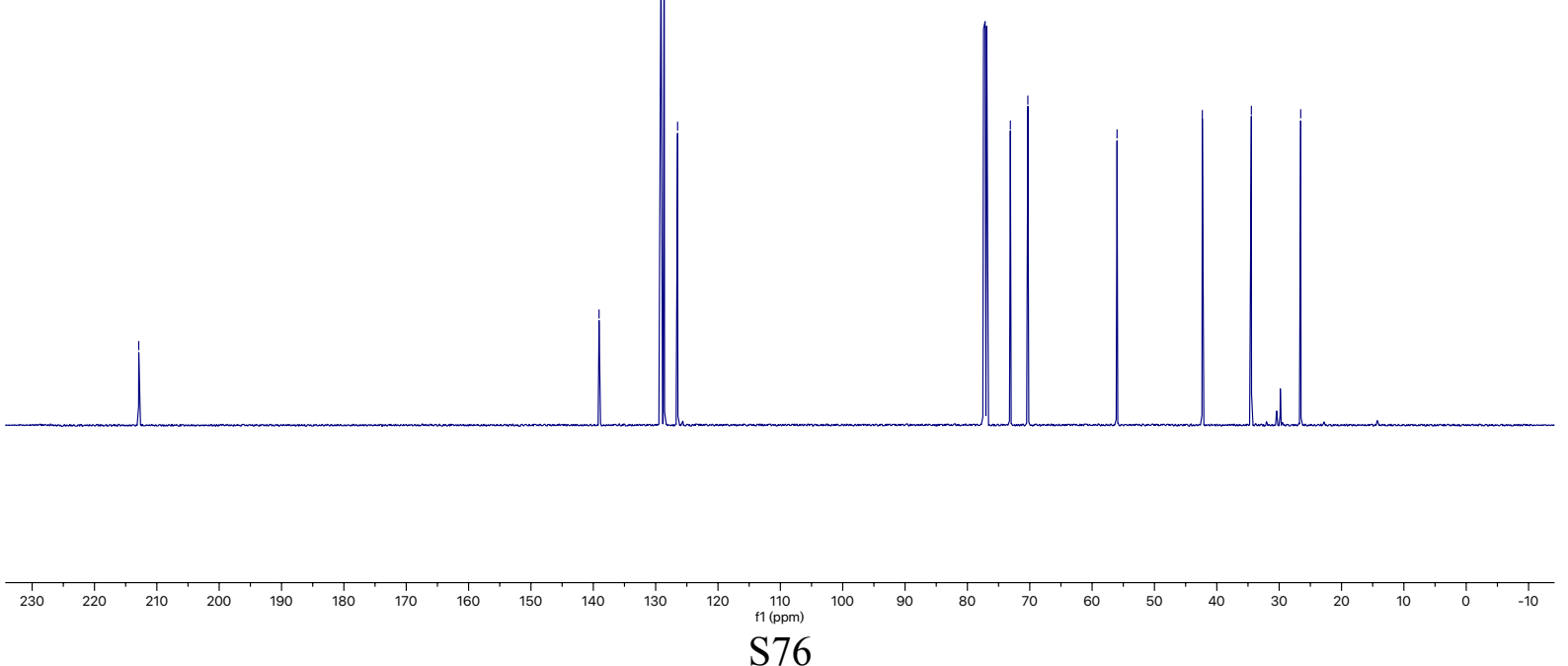

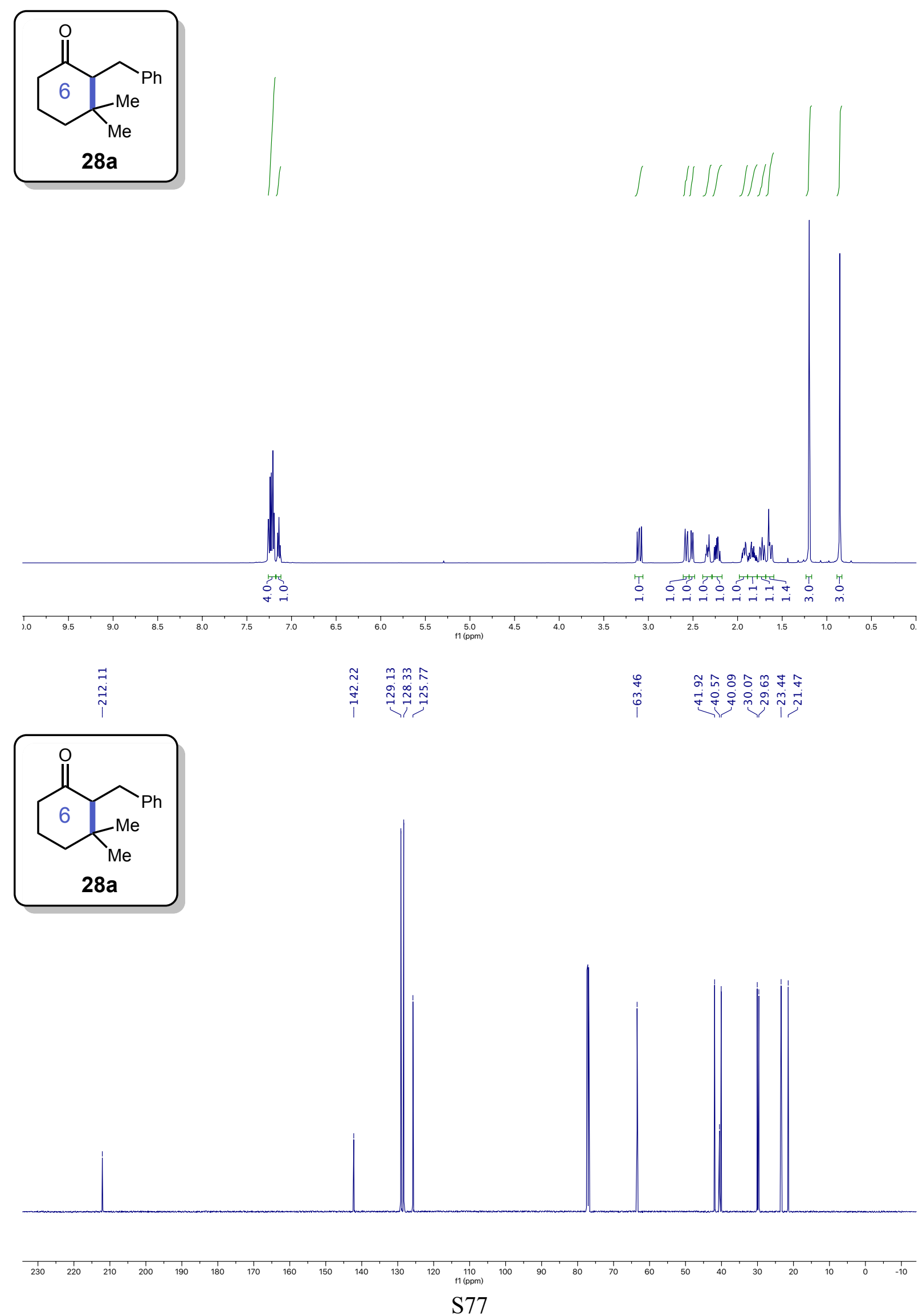


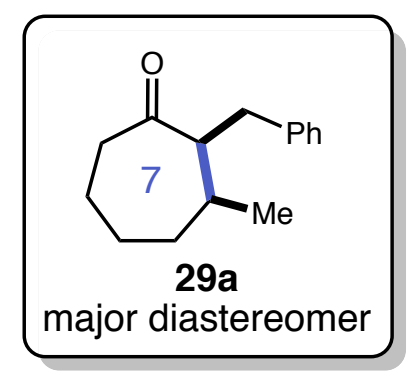

Crude in $\mathrm{CDCl}_{3}$ at $500 \mathrm{MHz}$
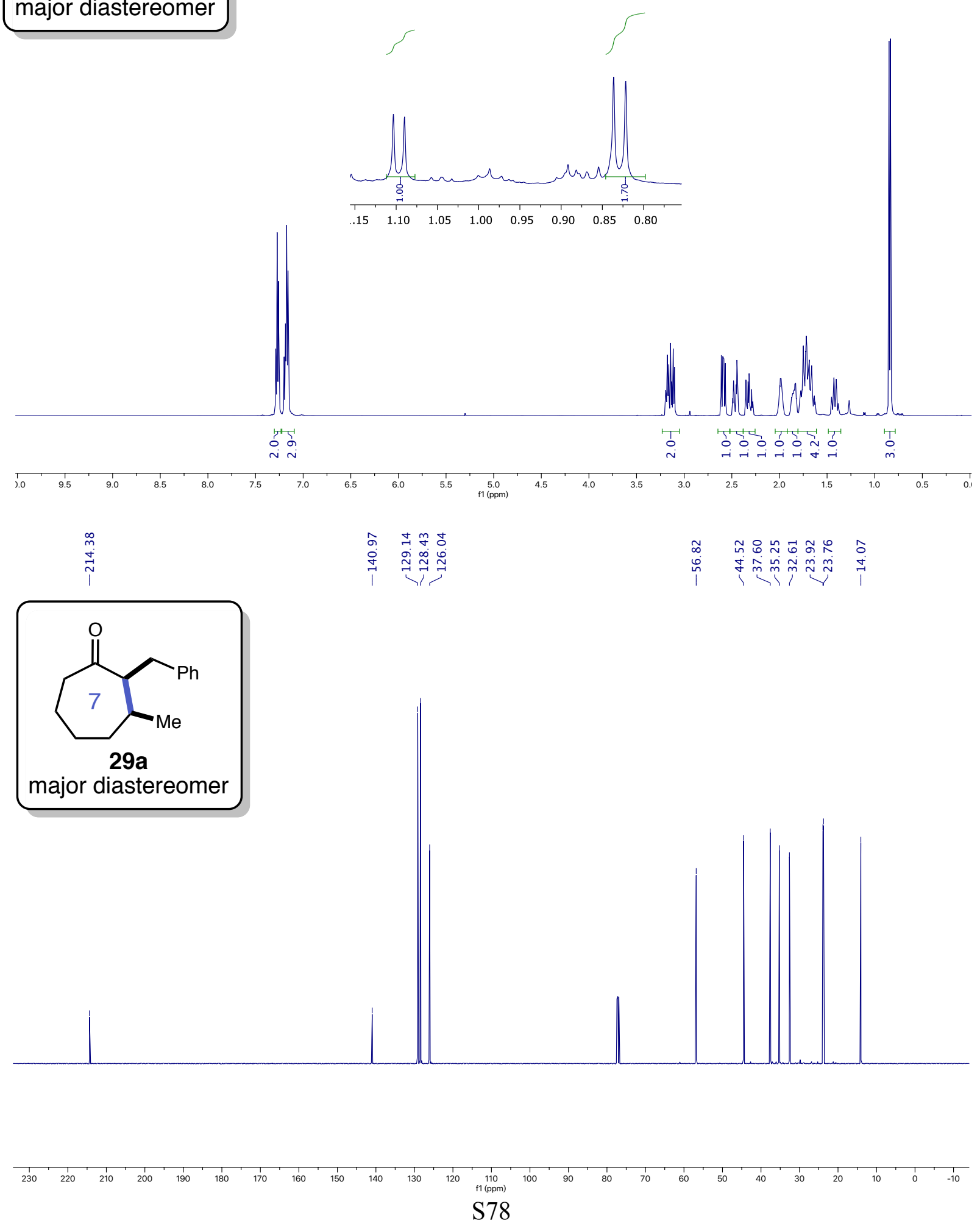

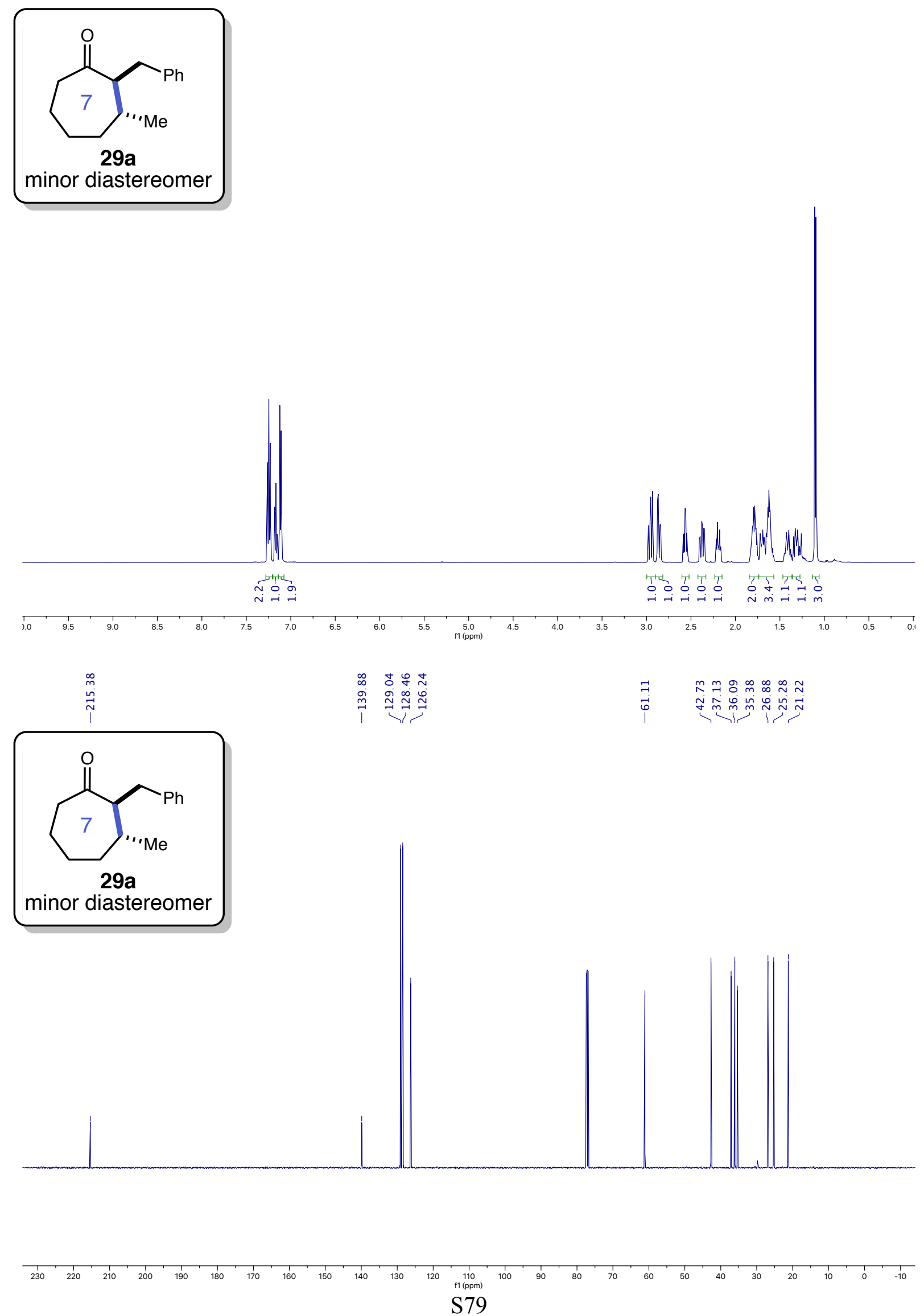


\section{NOESY Analysis of 29a}

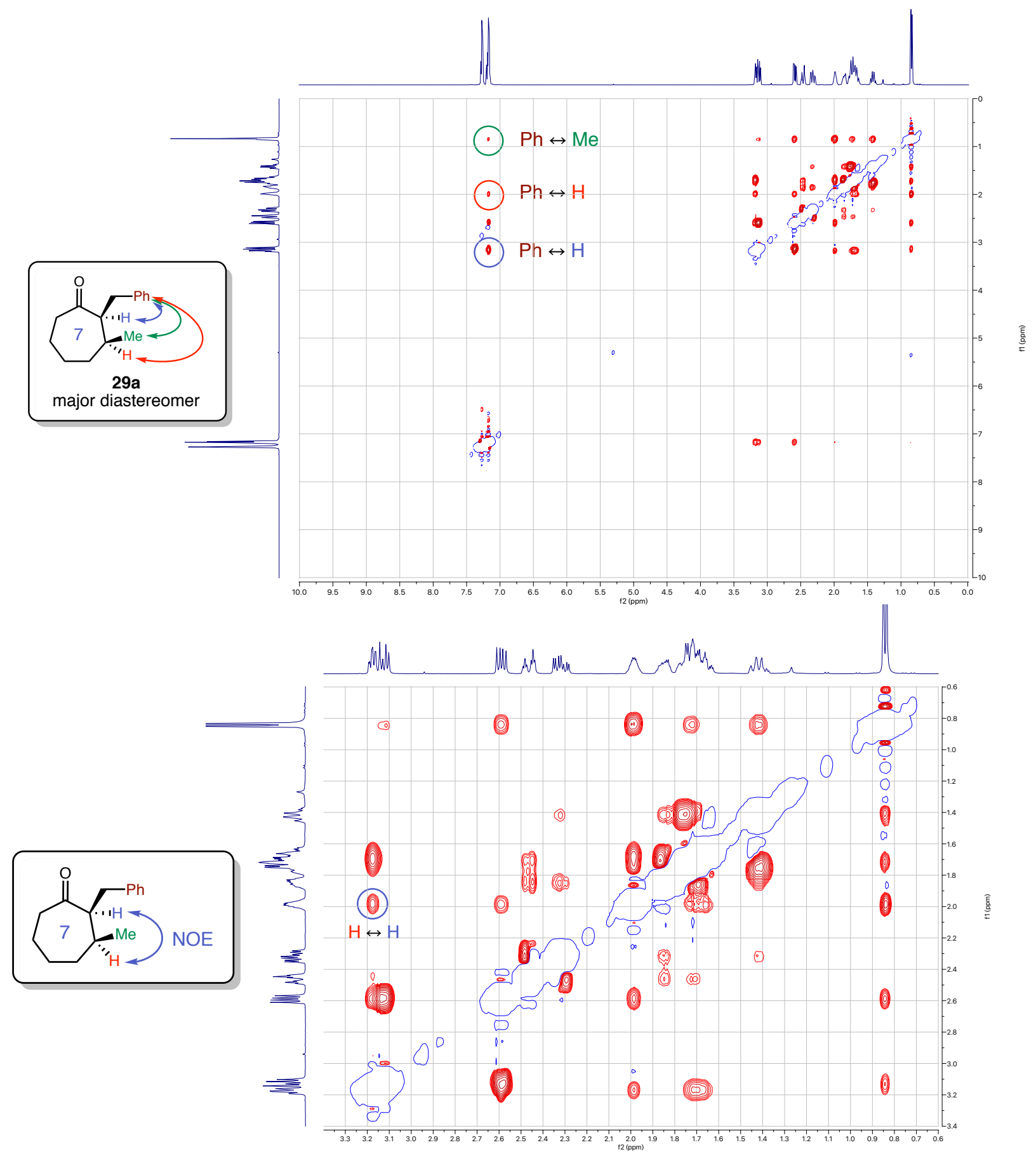

NOESY analysis of 29a (major diastereomer), annotated with important cross-peaks.

The $\alpha$-proton $(\mathrm{H})$ shows strong nuclear Overhauser effect (NOE) to the $\beta$-proton $(\mathrm{H})$, but no NOE is observed between the $\alpha$-proton $(\mathrm{H})$ and Me. This evidence indicates that the benzyl group and methyl group in the major isomer are in a cis conformation. 


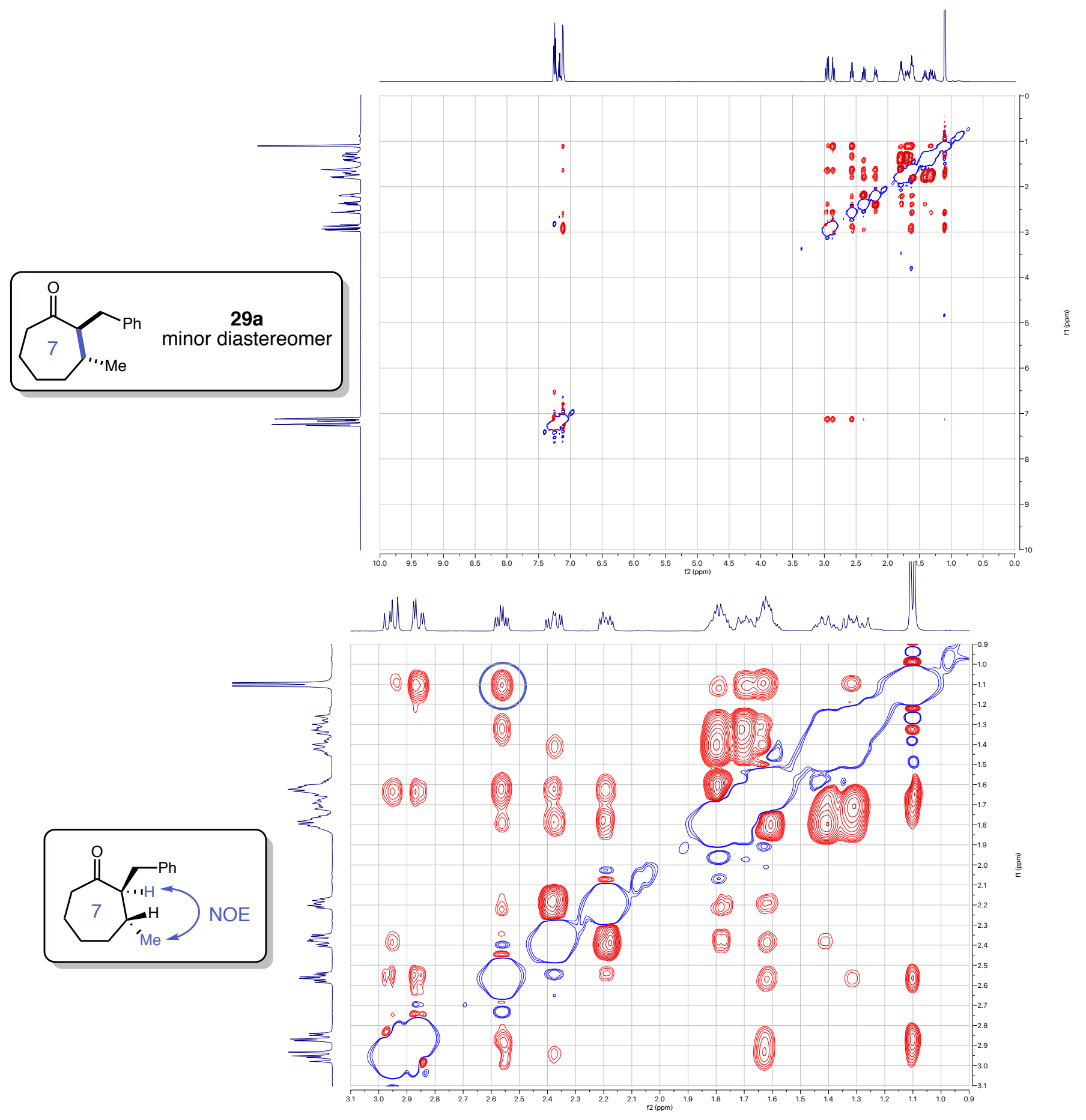

NOESY analysis of 29a (minor diastereomer), annotated with important cross-peaks. Unlike the NOESY of the cis isomer, the $\alpha$-proton $(\mathrm{H})$ shows strong NOE to the methyl group (Me). This evidence suggests a trans conformation for this minor isomer. 

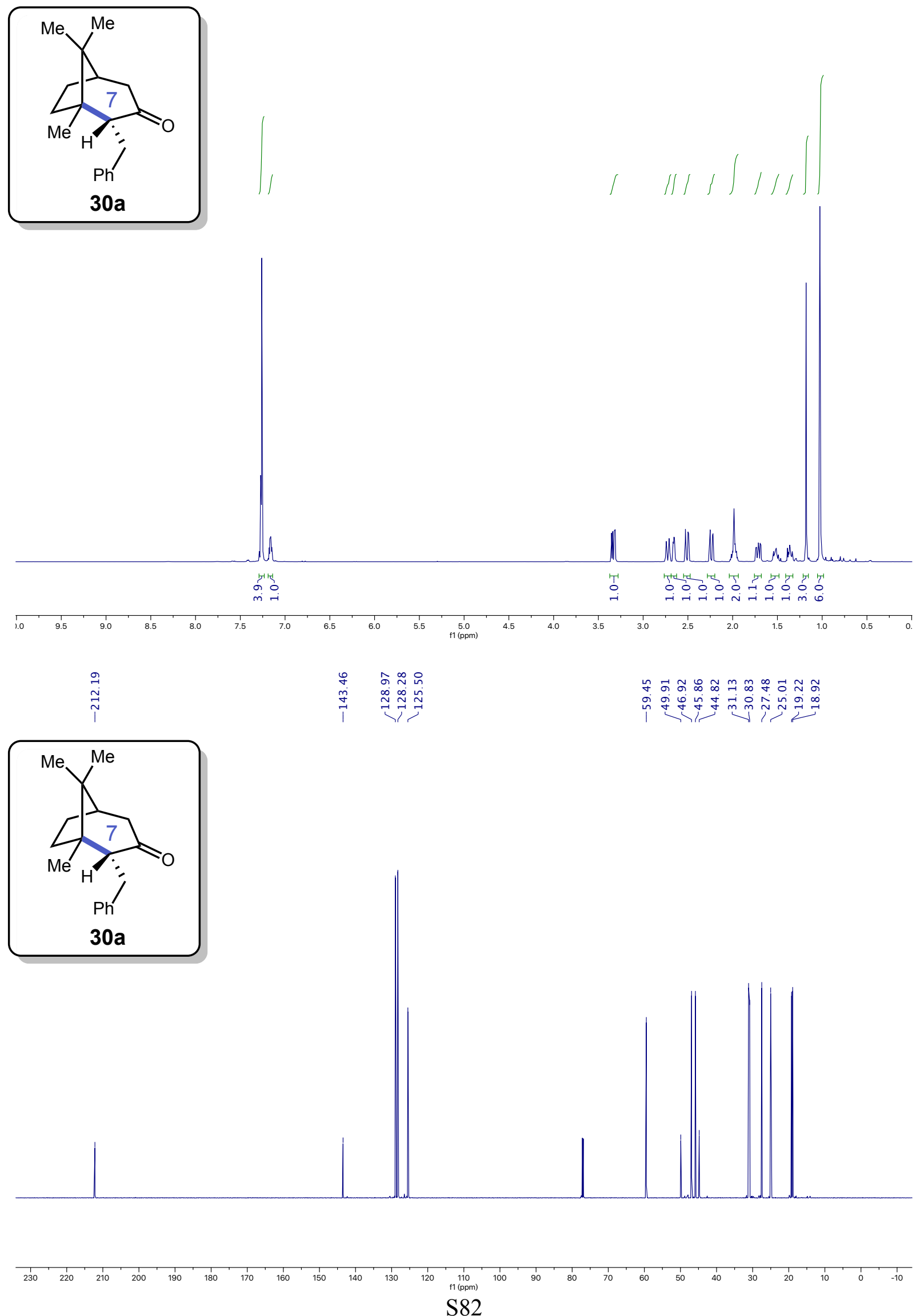


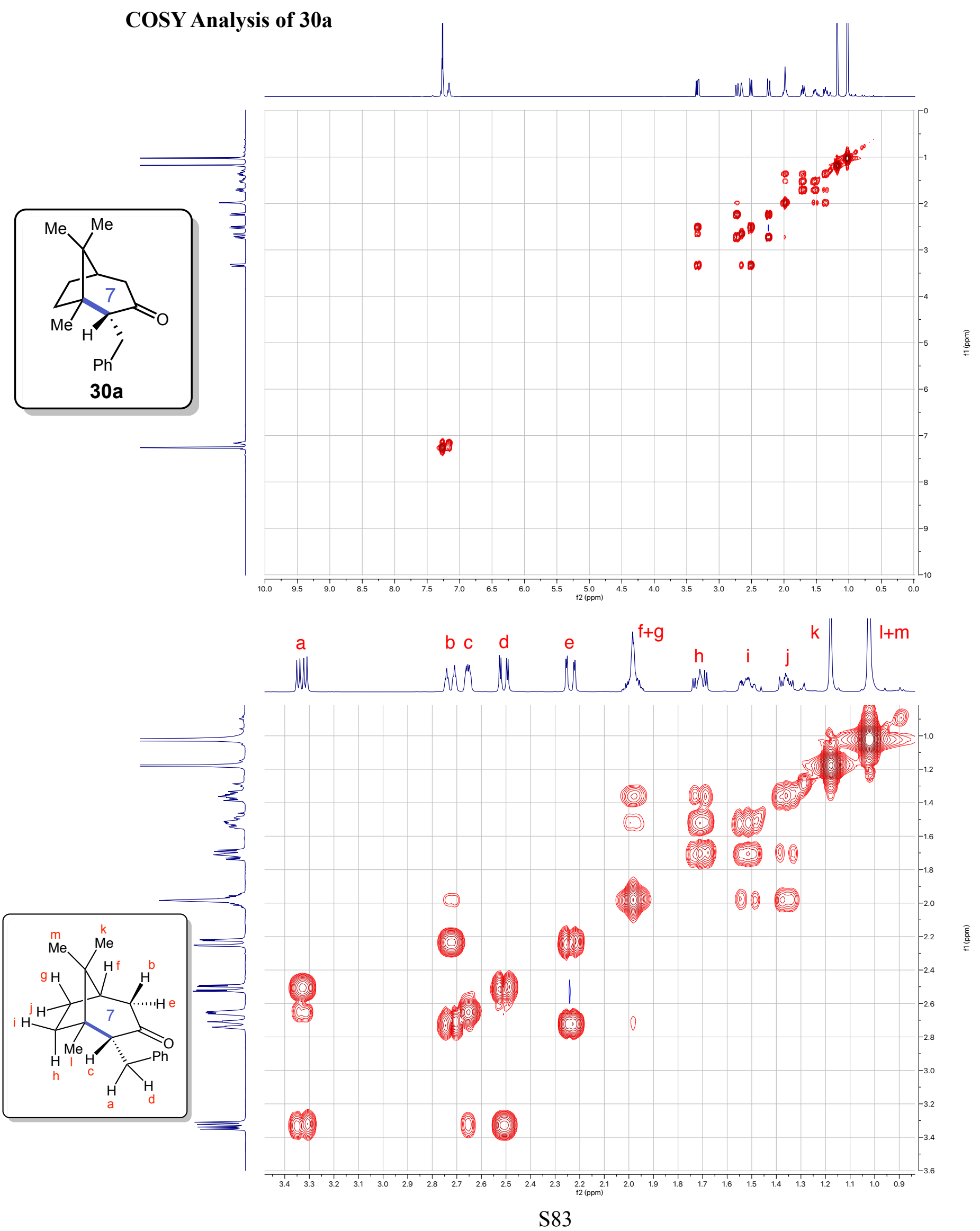




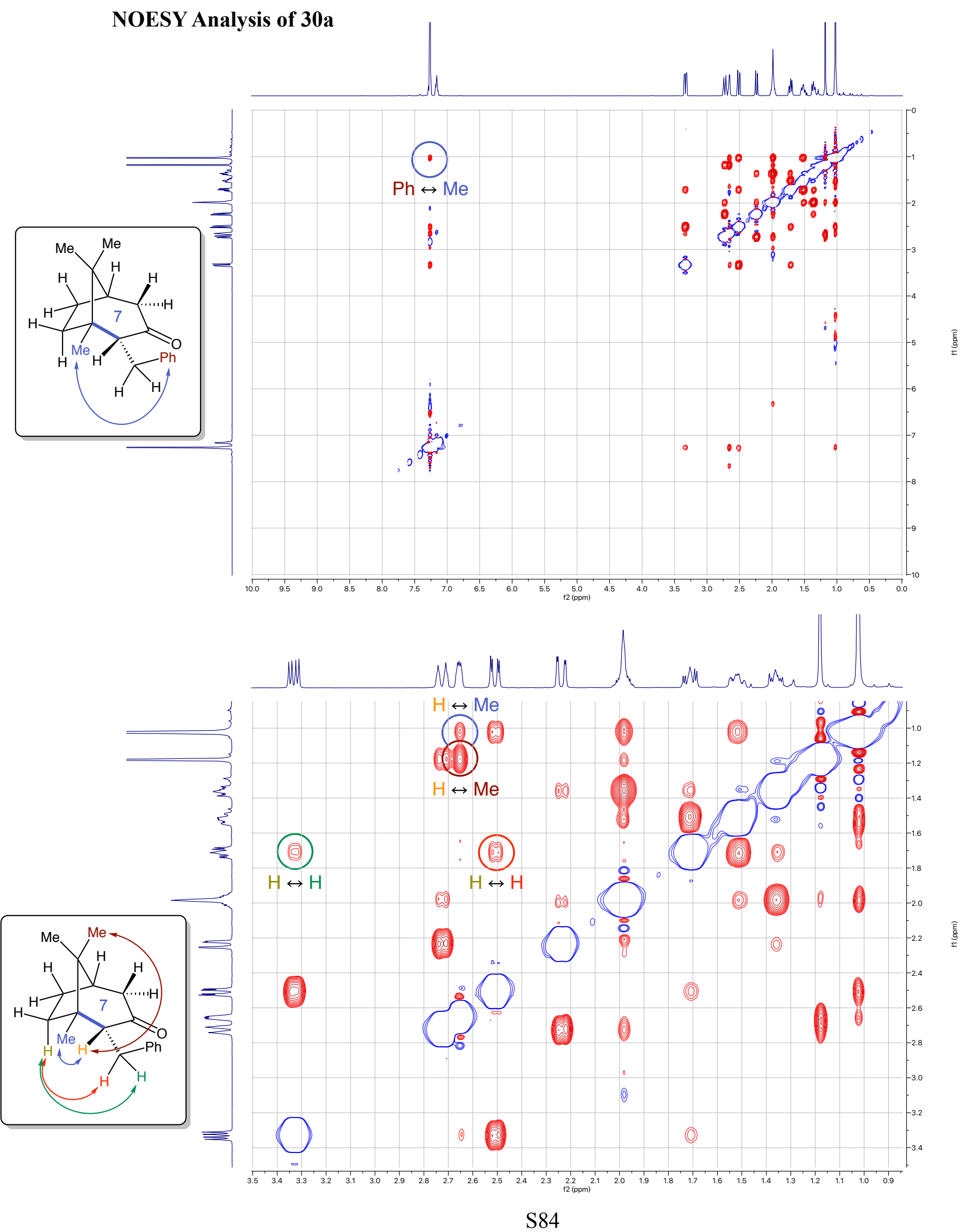



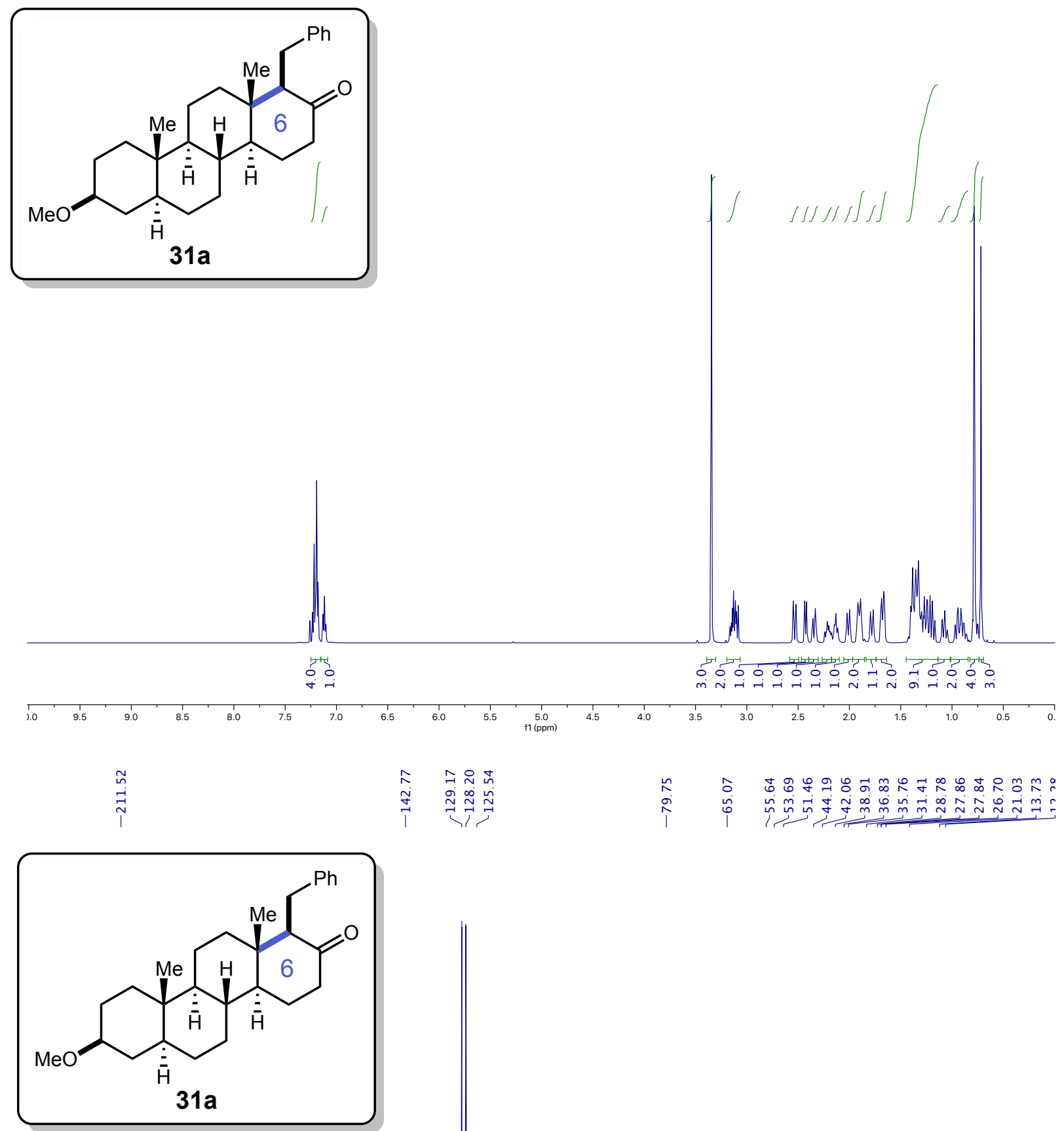

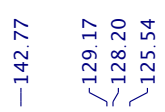

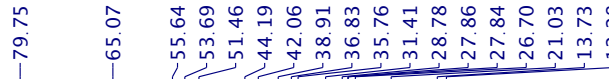
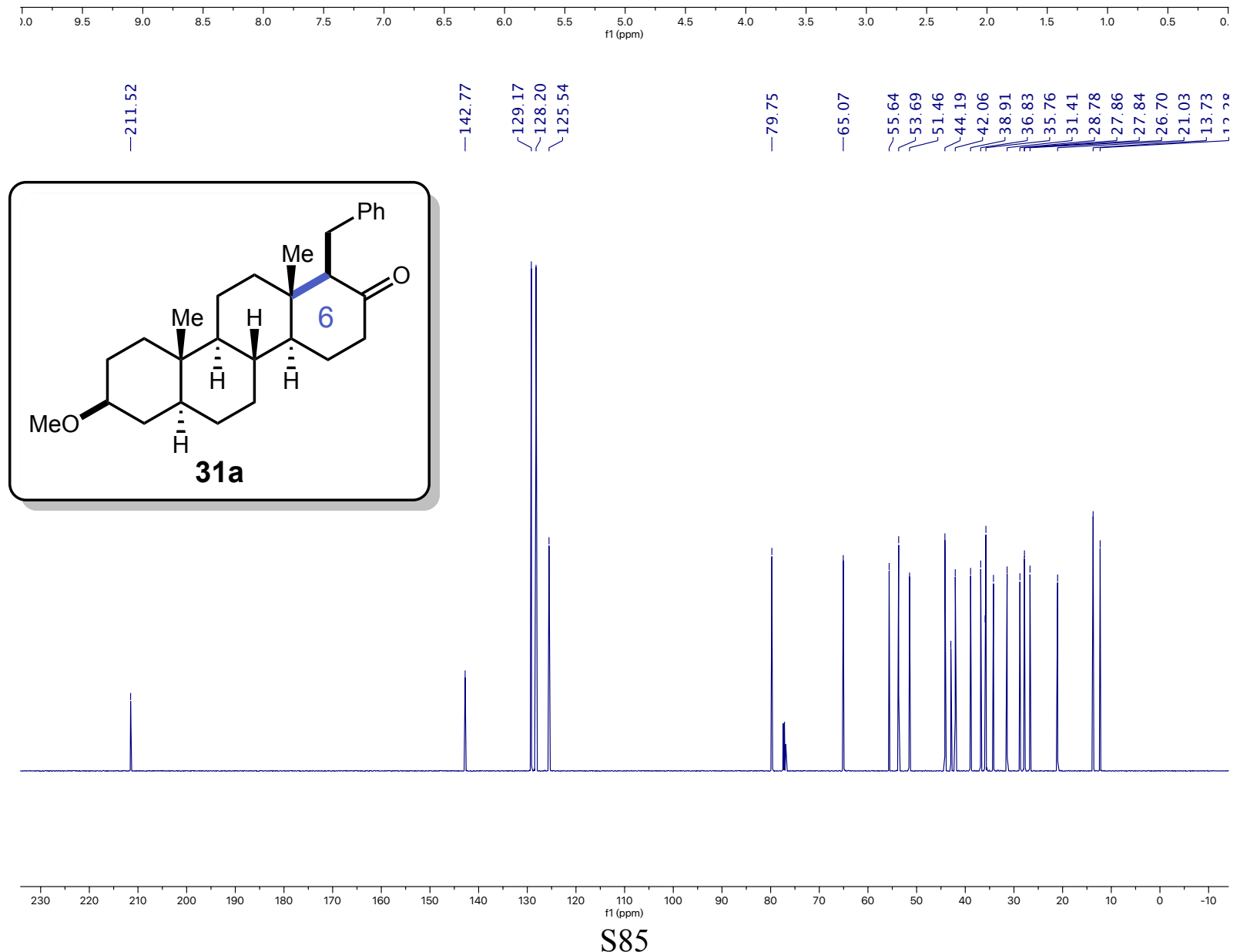


\section{Reference}

${ }^{1}$ Perrin, D. D.; Armarego, W. L. F. Purification of Laboratory Chemicals. $4^{\text {th }}$ ed.; ButterworthHeinemann: Oxford, 1997.

2 Pangborn, A. B.; Giardello, M. A.; Grubbs, R. H.; Rosen, R. K.; Timmers, F. J. Organometallics, 1996, 15, 1518.

${ }^{3}$ Dyeing reagents for thin layer and paper chromatography. http://www.cchem.berkeley.edu/rsgrp/TLCStainGeneralReference.pdf (accessed Mar. 11, 2019). The cobalt stain was found to be useful for carbamates and (1H-pyrazol-1-yl)containing molecules as well. For the original report on its use on amines, see: Lane, E. S. $J$. Chromatog. 1965, 18, 426. Phosphomolybdic acid (PMA) stain (10 wt $\%$ in ethanol) was found to be universally useful for organic compounds mentioned in this work. For the original report of PMA stain, see: Burstein, S. Anal. Chem., 1953, 25, 422.

${ }^{4}$ Ota, E.; Wang, H.; Frye, N. L.; Knowles, R. R. J. Am. Chem. Soc. 2019, 141, 1457.

${ }^{5}$ Ardolino, M. J..; Morken, J. P., J. Am. Chem. Soc. 2014, 136, 7092.

${ }^{6}$ Tanaka, K.; Kukita, K.; Ichibakase, T.; Kotani, S.; Nakajima, M. Chem. Commun. 2011, 47, 5614.

${ }^{7}$ Rimkus, A. M.; Alt, H. G. Polyhedron 2017, 126, 72.

${ }^{8}$ Kuang, J.; Xie, X.; Ma, S. Synthesis. 2013, 45, 592.

${ }^{9}$ Axenrod, T.; Sun, J.; Das, K. K.; Dave, P. R.; Forohar, F.; Kaselj, M.; Trivedi, N. J.; Gilardi, R. D.; Flippen-Anderson, J. L. J. Org. Chem. 2000, 65, 1200.

${ }^{10}$ Hřebabecký, H., Dejmek, M., Dračínský M., Šála M., Leyssen P., Neyts J., Kaniaková M., Krůšek J., Nencka R., Tetrahedron, 2012, 68, 1286.

${ }^{11}$ Hartman, George D. (Novira Therapeutics, Inc.) U.S. Patent 225355, May 14, 2015 (Location in patent: Paragraph 0410)

${ }^{12}$ Hartman, George D. (Novira Therapeutics, Inc.) U.S. Patent 225355, May 14, 2015 (Location in patent: Paragraph 0413)

${ }^{13}$ Watson, D. W.; Gill, M.; Kemmitt, P.; Lamont, S. G.; Popescu, M. V.; Simpson, I. Tetrahedron Lett. 2018, 59, 4479.

${ }^{14}$ Costa, B. R. D.; Bowen, W. D.; Hellewell, S. B.; George, C.; Rothman, R. B.; Reid, A. A.; Walker, J. M.; Jacobson, A. E.; Rice, K. C. J. Med. Chem. 1989, 32, 1996.

15 Garlets, Z. J.; Silvi, M.; Wolfe, J. P. Org. Lett. 2016, 18, 2331.

${ }^{16}$ Hashmi, A. S. K.; Wang, T.; Shi, S.; Rudolph, M. J. Org. Chem. 2012, 77, 7761.

${ }^{17}$ Smeyanov, A.; Schmidt, A. Synth. Commun. 2013, 43, 2809.

18 Yaragorla, S.; Pareek, A.; Dada, R. Tetrahedron Lett. 2017, 58, 4642.

${ }^{19}$ Cozzi, P. G.; Rudolph, J.; Bolm, C.; Norrby, P.-O.; Tomasini, C. J. Org. Chem. 2005, 70, 5733.

${ }^{20}$ Ishikawa, T.; Mizuta, T.; Hagiwara, K.; Aikawa, T.; Kudo, T.; Saito, S. J. Org. Chem. 2003, 68, 3702.

${ }^{21}$ Dikusar, E. A.; Kozlov, N. G.; Moiseichuk, K. L. Russ. J. Org. Chem. 2002, 38, 182. 
${ }^{22}$ Donohoe, T. J.; Pilgrim, B. S.; Jones, G. R.; Bassuto, J. A. Proc. Natl. Acad. Sci. U. S. A. 2012, 109, 11605.

${ }^{23}$ Kashiwagi, H.; Ono, Y.; Ohta, M.; Morikami, K.; Takahashi, T. Bioorg. Med. Chem. 2012, 20, 4495.

${ }^{24}$ Voigtritter K., Ghorai S., Lipshutz, B. H. J. Org. Chem., 2011, 76, 4697.

${ }^{25}$ Zhang, X.-M.; Tu, Y.-Q.; Zhang, F.-M.; Shao, H.; Meng, X. Angew. Chem., Int. Ed. 2011, 50, 3916

${ }^{26}$ Evans D. A., Nagorny P., Reynolds D. J., McRae K. J., Angew. Chem,. Int. Ed. 2007, 46, 541. 